Approved by:

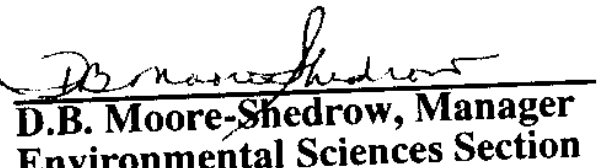

Environmental Sciences Section

July 1993

Westinghouse Savannah River Company

Savannah River Technology Center

Aiken, South Carolina 29808

Prepared for the Department of Energy under Contract DE-AC09-89SR18035 


\section{DEMONSTRATION OF RIVER CROSSING TECHNOLOGY FOR INSTALLATION OF ENVIRONMENTAL HORIZONTAL WELLS: AMH-6 AND AMH-7 INSTALLATION REPORT}

May 5, 1993

Westinghouse Savannah River Company Savannah River Site Aiken, South Carolina 29808 


\section{DISCLAIMER}

This report was prepared as an account of work sponsored by an agency of the United States Government. Neither the United States Government nor any agency thereof, nor any of their employees, makes any warranty, express or implied, or assumes any legal liability or responsibility for the accuracy, completeness, or usefulness of any information, apparatus, product, or process disclosed, or represents that its use would not infringe privately owned rights. Reference herein to any specific commercial product, process, or service by trade name, trademark, manufacturer, or otherwise does not necessarily constitute or imply its endorsement, recommendation, or favoring by the United States Government or any agency thereof. The views and opinions of authors expressed herein do not necessarily state or reflect those of the United States Government or any agency thereof.

This report has been reproduced directly from the best available copy.

Available to DOE and DOE contractors from the Office of Scientific and Technical Information, P. O. Box 62, Oak Ridge, TN 37831; prices available -.m (615) 576-8401.

Available to the public from the National Technical Information Service, U. S. Department of Commerce, 5285 Port Royal Rd., Springfield, VA 22161. 
Demonstration of River Crossing Technology for Installation of

Environmental Horizontal Wells: AMH-6 and AMH-7 Installation Report

CDM Federal Programs Corporation

May 5, 1993
Westinghouse Savannah River Company Subcontract No. AA46325P Task Order No. 10

\section{CONTENTS}

TABLE OF CONTENTS $\ldots \ldots \ldots \ldots \ldots \ldots \ldots \ldots \ldots \ldots \ldots \ldots$

LIST OF FIGURES $\ldots \ldots \ldots \ldots \ldots \ldots \ldots \ldots \ldots \ldots \ldots \ldots$

LIST OF ABBREVIATIONS, ACRONYMS, AND INITIALS $\ldots \ldots \ldots \ldots$ v

1.0 EXECUTIVE SUMMARY..................

2.0 INTRODUCTION $\ldots \ldots \ldots \ldots \ldots \ldots \ldots \ldots \ldots \ldots \ldots \ldots$

2.1 M-Area Settling Basin Background and Project Description ... 3

2.2 Objectives ....................... 4

3.0 GEOLOGIC SETTING . . . . . . . . . . . . . . 7

3.1 Regional Setting. ................... 7

3.2 A/M Area Hydrogeologic and Hydrostratigraphic Setting . . . . 7

3.2 .1 Santee Formation . . . . . . . . . . . . . 8

3.2.2 Dry Branch Formation . . . . . . . . . . .

3.2.3 Tobacco Road Formation. . . . . . ........... 9

3.2 .4 "Upland Unit" .................... 9

4.0 DRILLING SYSTEM $\ldots \ldots \ldots \ldots \ldots \ldots \ldots \ldots \ldots \ldots \ldots \ldots$

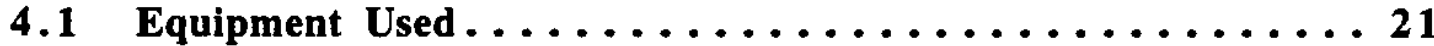

4.1.1 Drilling Rig. ................... 21

4.1.2 Down-Hole Drilling Assembly.............. 21

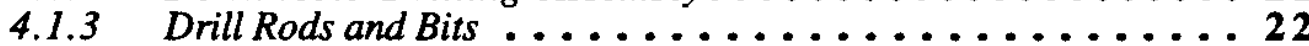

4.2 Drilling Fluid System $\ldots \ldots \ldots \ldots \ldots \ldots \ldots \ldots \ldots \ldots \ldots \ldots$

4.3 Drilling Procedures $\ldots \ldots \ldots \ldots \ldots \ldots \ldots \ldots \ldots \ldots \ldots 23$

4.4 Operating Conditions $\ldots \ldots \ldots \ldots \ldots \ldots \ldots \ldots \ldots \ldots 24$

5.0 TECHNICAL APPROACH $\ldots \ldots \ldots \ldots \ldots \ldots \ldots \ldots \ldots \ldots \ldots$

6.0 WELL CONSTRUCTION SUMMARY .............45

6.1 AMH-6 Borehole Construction - First Attempt ........45

6.2 AMH-7 Borehole Construction..............47

6.3 AMH-7 Well Installation .................49

6.4 AMH-6 Borehole Construction - Second Attempt........49

6.5 AMH-6 Well Installation $\ldots \ldots \ldots \ldots \ldots \ldots \ldots \ldots \ldots \ldots$

6.6 AMH-6 and AMH-7 Well Completion ............ 54

6.7 AMH-6 and AMH-7 Well Development ...........54

7.0 DISCUSSION ........................ 57

7.1 Analysis of the Drilling Program ............. 57

7.1.1 The Drilling Crew ................ 57

$7.1 .2 \quad$ The Drilling Fluid System . . . . . . . . . . 58

7.1.3 Specific Geologic Conditions and Fluid Losses . . . . . . . 61

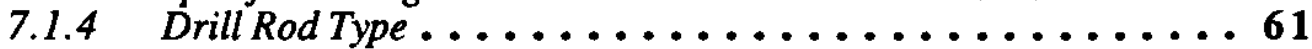

7.1 .5 Other Factors . . . . . . . . . . . . . 61 
Demonstration of River Crossing Technology for Installation of Environmental Horizontal Wells: AMH-6 and AMH-7 Installation Report CDM Federal Programs Corporation

Westinghouse Savannah River Company May 5, 1993

Subcontract No. AA46325P Task Order No. 10

7.2 Analysis of the Well Completion Method.............62

7.3 Well Development.......................6 62

8.0 CONCLUSIONS $\ldots \ldots \ldots \ldots \ldots \ldots \ldots \ldots \ldots \ldots \ldots \ldots \ldots \ldots \ldots \ldots \ldots$

9.0 RECOMMENDATIONS AND SUGGESTIONS FOR FUTURE

ACTIVITIES . . . . . . . . . . . . . . . . . . . . 65

9.1 Recommendations . . . . . . . . . . . . . . . . . 65

9.2 Suggestions For Future Activities................. 65

REFERENCES . . . . . . . . . . . . . . . . . 67

Appendix A Summary of Broken Washover Pipe Recovery Activities . . A-1

Appendix B Daily Activity Reports..................... B-1

Appendix C M Area Horizontal Drilling Photographs ............. C-1

Appendix D Horizontal Well Construction Diagrams $\ldots \ldots \ldots \ldots \ldots \ldots \ldots \ldots$. . .

Appendix E Horizontal Well As-Built Diagrams . . . . . . . . . . . E E-1

Appendix F Specific Information on Guar Gum Drilling Additive . . . . F-1 
Demonstration of River Crossing Technology for Installation of Environmental Horizontal Wells: AMH-6 and AMH-7 Installation Report CDM Federal Programs Corporation

May 5, 1993
Westinghouse Savannah River Company Subcontract No. AA46325P Task Order No. 10

\section{LIST OF FIGURES}

2-1 Location of the SRS in South Carolina .................5

2-2 Location of M-Area Settling Basin Hazardous Waste Management

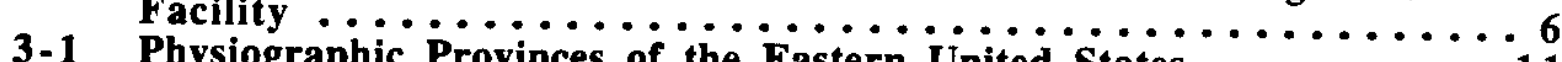

3-2 Physiographic Provinces of the Eastern United States . . . . . . 11

3-3 Physiographic Subprovinces of the South Carolina Coastal Plain . . 12 Comparison of Chronostratigraphic, Lithostratigraphic, and

3-4 Hydrostratigraphic Units at the SRS ............... 13

3-5 Trace of Relatiof Abandoned Borehole AMH-6 in Cross Section with

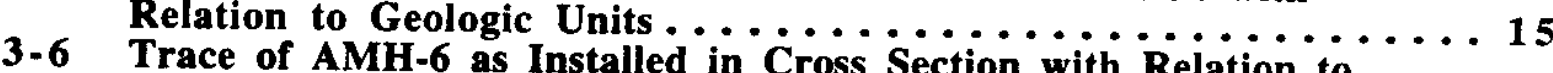

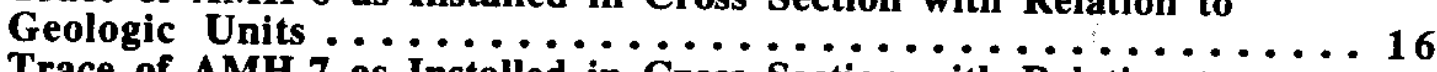

3-7 Trace of AMH-7 as Installed in Cross Section with Relation to

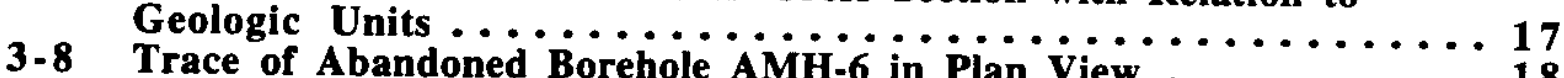

3.9 Trace of AMH-6 as Borehole AMH-6 in Plan View $\ldots \ldots \ldots \ldots \ldots 18$

3-10 Trace of AMH-7 as Installed in Plan View $\ldots \ldots \ldots \ldots \ldots \ldots$

$4-1$ Oblique View of MC-90 Drilling $\mathrm{Rin}$ View $\ldots \ldots \ldots \ldots \ldots \ldots \ldots$

4-2 Down-Hole Dillic

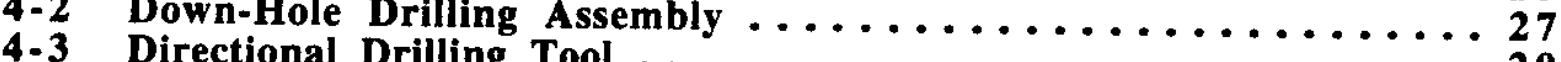

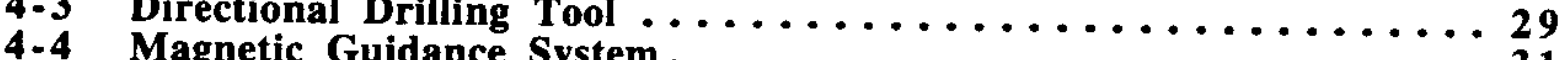

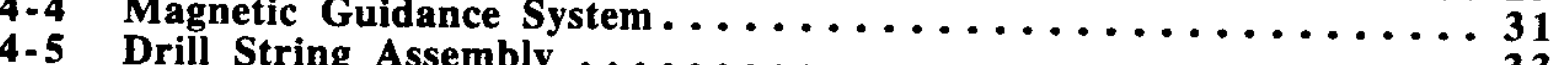

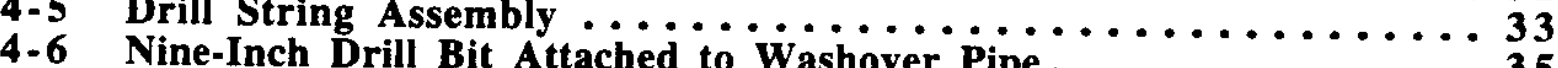

4-7 Mud System Set- Attached to Washover Pipe ........... 35

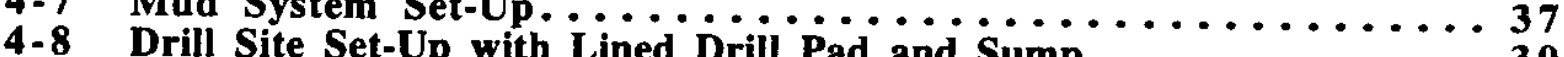

5.1 Proposed

5.2 Piapod Path (Plan View) of Horizontal Wells in $M$ A rea.......43

$6-1$ Diagram (in Cross Section) of Horizontal Well Layout ........ 44

Perforated Two-Inch Diameter PVC Plug for Well Development . . . 56

A-1 Fishing Tool for Extraction of Broken Washover Pipe.......... A-9

$\begin{array}{ll}\text { A-2 } & \text { Vibrating Hammer for Extraction of Broken Washover Pipe } \ldots \ldots \ldots A \text { A-11 } \\ \text { A-3 wo-Inch Diameter Hook for Extraction of Broken Washover }\end{array}$

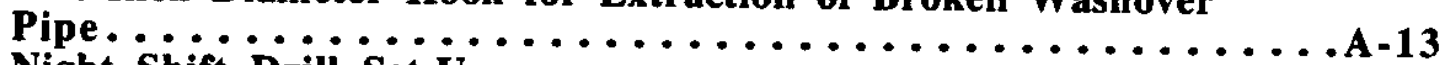

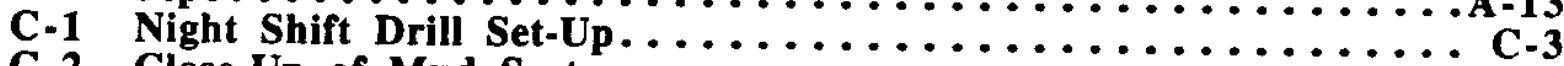

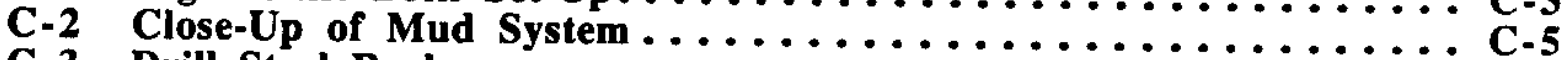

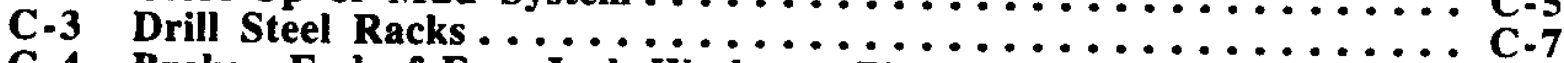

C-4 Broken End of Four-Inch Washover Pipe $\ldots \ldots \ldots \ldots \ldots \ldots \ldots$ C-9

C-5 Fishing Tool Preparing to be Installed.................

C-6 Plate for Attaching Hammer to Four-Inch Washover Pipe $\ldots \ldots \ldots$.

C.7 Crane for Moving Vibrating Hammer $\ldots \ldots \ldots \ldots \ldots \ldots \ldots \ldots$ C-15

C-8 D-8 Bulldozer Pulling on Struck Washover Pipe . . . . . .

C-9 Two D-8 Bulldozers Pulling in Tandem on Stuck Washover Pipe ..C-19

C.10 Crew Installing Three-Inch PVC Well Screen in Hole .........

C-11 Four-Inch Washover Pipe Being Extracted from Over Installed

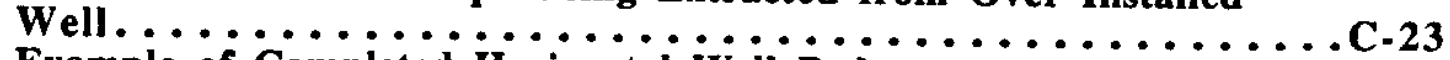

C-12 Example of Completed Horizontal Well Pad $\ldots \ldots \ldots \ldots \ldots \ldots \ldots$ C-25 
Demonstration of River Crossing Technology for Installation of Environmental Horizontal Wells: AMH-6 and AMH-7 Installation Report CDM Federal Programs Corporation

May 5, 1993
Westinghouse Savannah River Company Subcontract No. AA46325P Task Order No. 10

\section{LIST OF FIGURES (Continued)}

D-1 AMH-6 Horizontal Well Construction Diagram ............ D-3

D-2 AMH-7 Horizontal Well Construction Diagram ............. D-4

E-1 Horizontal Well AMH-6 As-Built.................... E-3

E-2 Horizontal Well AMH-7 As-Built..................... E-4 
Demonstration of River Crossing Technology for Installation of Environmental Horizontal Wells: AMH-6 and AMH-7 Installation Report CDM Federal Programs Corporation

May 5, 1993
Westinghouse Savannah River Company

Subcontract No. AA46325P

Task Order No. 10

\section{LIST OF ABBREVIATIONS, ACRONYMS, AND INITIALS}

$\begin{array}{ll}\text { BHA } & \text { Non-Magnetic Bottom Hole Assembly } \\ \text { CDM Federal } & \text { CDM Federal Programs Corporation } \\ \text { CEC } & \text { EVI Cherrington Environmental Corporation } \\ \text { DOE } & \text { Department of Energy } \\ \text { ECEC } & \text { Eastman Christensen Environmental Corporation } \\ \text { EMTC } & \text { Environmental Monitoring and Testing Corporation } \\ \text { ft-lbs } & \text { foot-pounds } \\ \text { ID } & \text { internal diameter } \\ \text { lb } & \text { pound } \\ \text { MD } & \text { measured depth } \\ \text { MGS } & \text { Magnetic Guidance System } \\ \text { msl } & \text { Mean Sea Level } \\ \text { OD } & \text { outside diameter } \\ \text { PCE } & \text { Tetrachloroethylene } \\ \text { PID } & \text { photoionization detector } \\ \text { Ppm } & \text { parts per million } \\ \text { pSi } & \text { pounds per square inch } \\ \text { PVC } & \text { polyvinyl chloride } \\ \text { RCRA } & \text { Resource Conservation and Recovery Act } \\ \text { Tpms } & \text { revolutions per minute } \\ \text { SAIC } & \text { Science Applications International Corporation } \\ \text { SRS } & \text { Savannah River Site } \\ \text { SRTC } & \text { Savannah River Technology Center } \\ \text { TCE } & \text { Trichloroethylene } \\ \text { TVD } & \text { true vertical depth } \\ \text { VD } & \text { vertical depth } \\ \text { VOCs } & \text { volatile organic compounds } \\ \text { WSRC } & \text { Westinghouse Savannah River Company } \\ & \end{array}$


Demonstration of River Crossing Technology for Installation of

Environmental Horizontal Wells: AMH-6 and AMH-7 Installation Report

CDM Federal Programs Corporation

May 5, 1993
Westinghouse Savannah River Company Subcontract No. AA46325P Task Order No. 10

THIS PAGE INTENTIONALLY LEFT BLANK 
Demonstration of River Crossing Technology for Installation of Environmental Horizontal Wells: AMH-6 and AMH-7 Installation Report CDM Federal Programs Corporation

May 5, 1993
Westinghouse Savannah River Company

Subcontract No. AA46325P

Task Order No. 10

\subsection{EXECUTIVE SUMMARY}

The Department of Energy's (DOE) Office of Technology Development initiated an integrated demonstration of innovative technologies and systems for cleanup of volatile organic compounds (VOCs) in soils and groundwater. This drilling project is part of the directional drilling task for the integrated technology demonstration at the Savannah River Site (SRS). One of the objectives of the drilling task is the demonstration of multiple drilling technologies. The technologies can then be compared and evaluated in terms of technical performance and cost effectiveness. Petroleum horizontal well technology and utility industry horizontal well technology have been previously demonstrated at the SRS. The petroleum industry directional drilling technology was demonstrated by Eastman Christensen Environmental Corporation (ECEC). ECEC directionally drilled and installed four horizontal wells in the M Area. Charles Machine Works, working with Sandia National Laboratory, demonstrated a utility industry directional drilling technology by installing one horizontal well in the M Area. The demonstration that is the subject of this report involved river crossing horizontal well technology for the installation of two M-Area Settling Basin soil gas extraction wells.

EVI Cherrington Environmental Corporation (CEC) was chosen for this demonstration. CEC developed directional drilling expertise in the river crossing industry and is an industry leader in horizontal well installation.

Two horizontal wells were installed beneath the M-Area Settling Basin at the $A / M$ Area of the SRS. Documented releases from the M-Area Settling Basin have contaminated the underlying vadose zone and groundwater with VOCs. The vadose zone has retained a large portion of the VOCs and now acts as a secondary source of contamination. The wells are parallel to one another and are oriented southwest to northeast. The horizontal wells were installed approximately 10 feet above the water table and were planned to have a horizontal screen underlie the width of the basin. The wells will be part of a soil vapor extraction system designed to remediate the vadose zone and act as a barrier to prevent further contamination of the groundwater.

The installation of the horizontal wells was a two-part process. Part one consisted of constructing the borehole, and part two was the horizontal well completion. Borehole construction was attempted by first directionally drilling a pilot hole with a small diameter drill pipe and a hydraulic spud-jet drilling tool. The pilot hole was expanded with a larger diameter "washover" pipe that was circumferentially drilled over the pilot drill string. The pilot drill string was retracted from the washover pipe once the washover pipe had been drilled over the entire pilot string and the borehole was complete. The well materials were then installed inside the washover pipe. The washover pipe was withdrawn from the borehole once the well materials were in the proper position.

Difficulties were encountered during construction of the borehole for AMH-6. The first attempt at constructing the borehole for AMH-6 was unsuccessful because the washover drilling pipe became stuck in the borehole and could not be removed. The second attempt at constructing the AMH-6 borehole was partially successful. Washover drilling pipe once more became stuck in the borehole. The construction of the borehole for well AMH-7 was successfully completed during the first attempt. 
May 5, 1993

- The installation of the two horizontal wells was successful. The borehole of AMH-6 was 20 feet short, and four-inch washover pipe left in the hole obstructed another 170 feet of the installed well screen. The result was 230 feet of effective well screen placed in the target horizon instead of 420 feet. The AMH-7 well screen was successfully placed in the target horizon and had a total horizontal well screen length of 420 feet.

The following conclusions were reached upon completion of the drilling demonstration.

1. River crossing industry type directional drilling technology is capable of successfully installing horizontal wells under the M-Area Settling Basin.

2. The drilling crew was inexperienced in installing deep (greater than 50 vertical feet) horizontal wells.

3. The hydraulic spud-jet drilling tool was inefficient. A downhole drill motor should have been used to improve drilling efficiency.

4. The washover pipe became stuck in AMH-6 because the radius of curvature of the borehole (400 feet) was not large enough to accommodate the drill pipe and the washover pipe was not of the proper strength.

5. The guar gum-based drilling fluid system was inadequate. The drilling fluid system should have been improved, or a bentonite-based drilling fluid should have been considered. The drilling crew did not keep drilling records or mud reports during this project. Therefore, the drilling crew was unprepared to adapt to the site conditions. 
Demonstration of River Crossing Technology for Installation of Environmental Horizontal Wells: AMH-6 and AMH-7 Installation Report CDM Federal Programs Corporation

May 5, 1993
Westinghouse Savannah River Company

Subcontract No. AA46325P

Task Order No. 10

\subsection{INTRODUCTION}

The SRS is part of the United States DOE Nuclear Weapons Complex. Its main function is to produce nuclear materials for national defense. The SRS is located in south-central South Carolina and occupies an area of approximately 300 square miles (192,000 acres) (Fig. 2-1). The major physiographic feature is the Savannah River which forms the southwestern boundary of the site and is also the South Carolina-Georgia border. The SRS includes portions of Aiken, Barnwell, and Allendale Counties in South Carolina.

The DOE Office of Technology Development initiated an integrated demonstration of innovative technologies and systems for cleanup of VOCs in soils and groundwater at the SRS in 1989. The overall goal of the program is demonstration of multiple technologies and systems in the fields of drilling, characterization, monitoring, and remediation at a single test bed. Innovative technologies are compared to one another and to baseline technologies in terms of technical performance and cost effectiveness. Transfer of successfully demonstrated technologies and systems to DOE environmental restoration organizations, to other government agencies, and to industry is a critical part of the program. Directional drilling and horizontal well installation are the innovative technologies demonstrated in this task.

Directional drilling and horizontal well installation have been shown to be successful techniques for enhancing access to the subsurface where vertical wells are impractical or impossible to install. During this task two horizontal wells were installed to be used for vapor extraction of VOCs from the vadose zone beneath the M-Area Settling Basin. The task was initiated in November 1992 and completed in December 1992.

\subsection{M-Area Settling Basin Background and Project Description}

The M Area (3/700 Area), located in the northwestern portion of the SRS (Fig. 2-1), is the site of the metals fabrication facility where fuel targets for the reactors were fabricated. The M-Area Settling Basin was used as a settling basin for metal-rich wastes that contained solvents. Hydrologic investigations at the SRS have shown that M-Area operations have resulted in the contamination of the groundwater with VOCs near the M-Area Settling Basin (Fig. 2-2). The contamination at this site resulted from the leakage of waste solvents from the M-Area Settling Basin, now closed and capped according to Resource Conservation and Recovery Act (RCRA) guidelines, into the vadose zone with subsequent gravity-driven migration of the contaminants into the groundwater. A remedial action program consisting of groundwater pumping from eleven vertical recovery wells, followed by above-ground airstripping in a central tower, was implemented in 1985 to address groundwater contamination in M Area.

The Savannah River Technology Center (SRTC) performed a pilot test in 1986 and 1987 to evaluate the removal of VOCs from the vadose zone in the M Area using a vacuum extraction system. The pilot test utilized three horizontal and one vertical extraction well along the process sewer line leading to the basin. In one three-week period, 1500 pounds of VOCs were extracted through the vertical extraction well. A full-scale extraction program was planned based on the results of the pilot test. The full-scale program includes two horizontal soil vapor extraction wells installed beneath the basin. This report will deal exclusively with the drilling of the horizontal boreholes and the installation of horizontal wells AMH-6 and AMH-7. 
Demonstration of River Crossing Technology for Installation of Environmental Horizontal Wells: AMH-6 and AMH-7 Installation Report CDM Federal Programs Corporation

May 5, 1993
Westinghouse Savannah River Company Subcontract No. AA46325P Task Order No. 10

A drilling team was retained by SRTC for the design, drilling, and installation of the horizontal wells. Drilling experts from CEC designed the borehole and provided the drilling and well completion materials. Sharewell Inc. was subcontracted by CEC to provide the directional surveying equipment. Environmental Monitoring and Testing Corporation (EMTC) (New Ellenton, SC) was subcontracted by CEC to provide a South Carolina-certified driller and local access to equipment as necessary. CDM Federal Programs Corporation (CDM Federal) (Aiken, SC) was retained by the SRTC to function as the onsite SRTC representative and implement the following services: (1) provide technical oversight, (2) document project activities, and (3) generate the horizontal well completion report. SRTC provided program management.

\subsection{Objectives}

The objectives of the M-Area Settling Basin demonstration were: (1) to test and evaluate one technique of horizontal well installation technology adapted from the river crossing industry; (2) to drill boreholes in unconsolidated sediments (sands, gravels, and silts) and semiconsolidated clay units beneath the M-Area Settling Basin; and (3) to install two horizontal wells in the vadose zone for vapor extraction of VOCs from soil. 
Demonstration of River Crossing Technology for Installation of

Westinghouse Savannah River Company Environmental Horizontal Wells: AMH-6 and AMH-7 Installation Report CDM Federal Programs Corporation

Subcontract No. AA46325P

May 5, 1993

Task Order No. 10

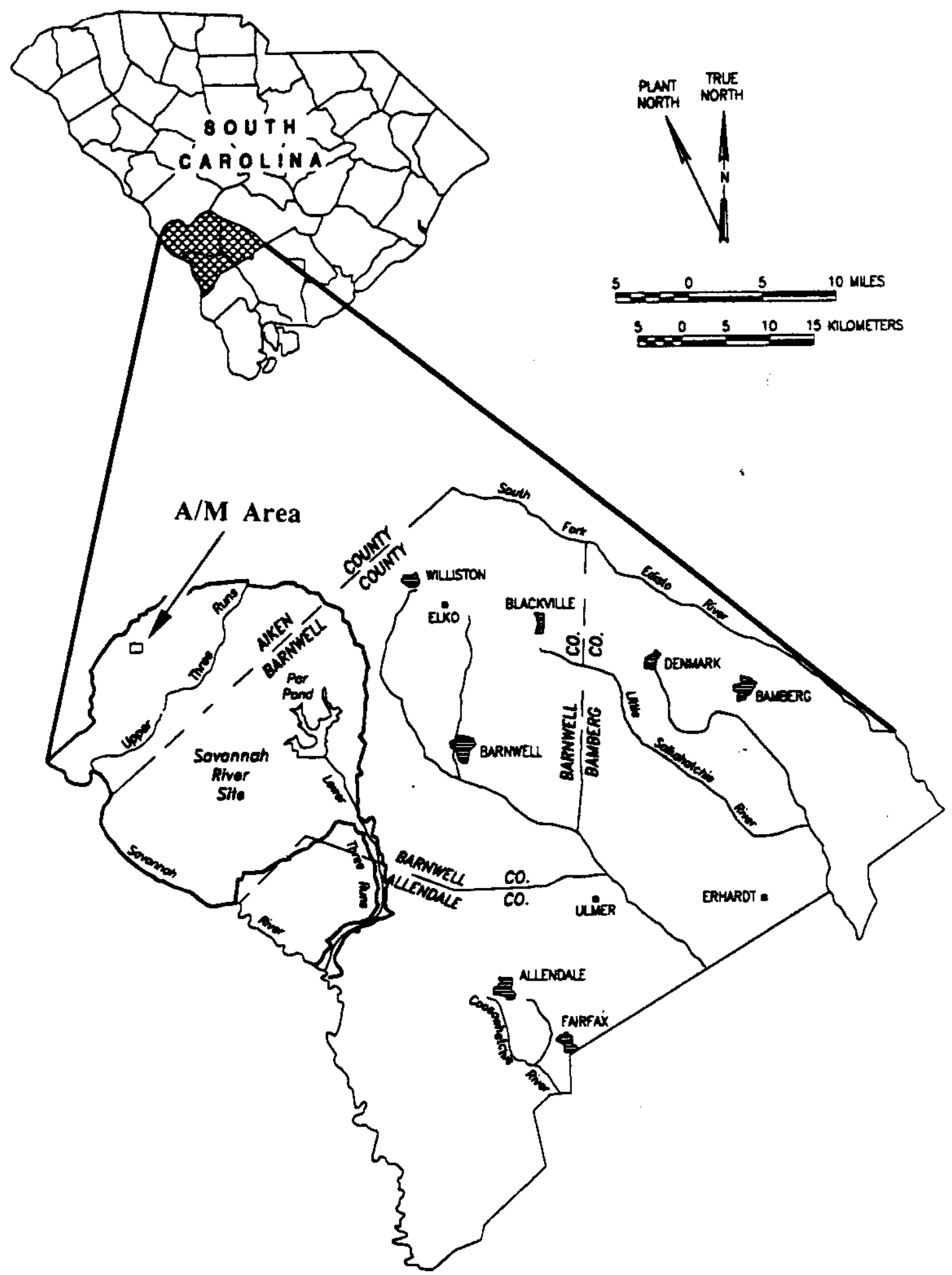

Figure 2-1. Location of the SRS in South Carolina 
Demonstration of River Crossing Technology for Installation of Environmental Horizontal Wells: AMH-6 and AMH-7 Installation Report CDM Federal Programs Corporation

Westinghouse Savannah River Company May 5, 1993

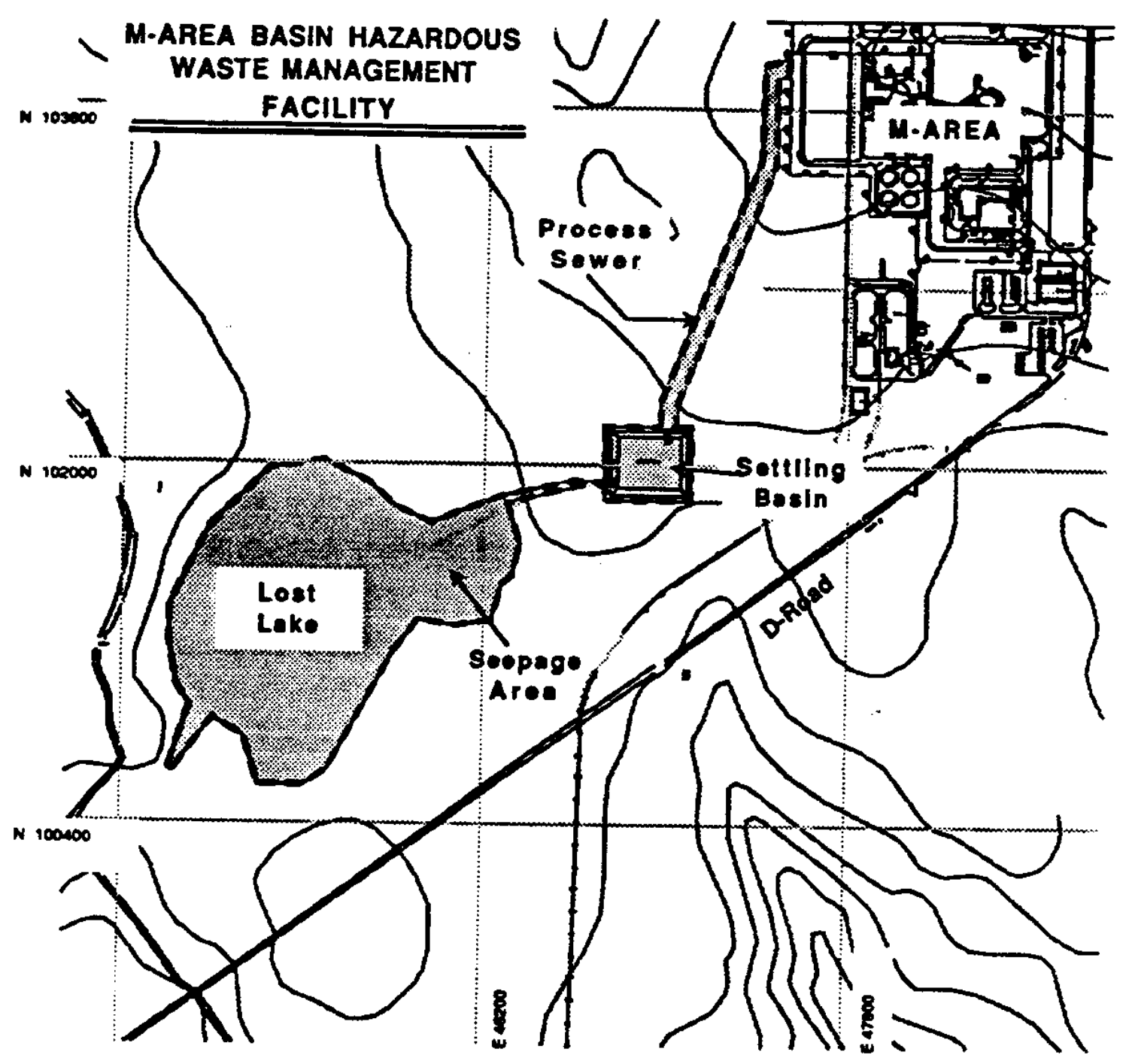

Figure 2-2. Location of M-Area Settling Basin Hazardous Waste Management Facility 
Demonstration of River Crossing Technology for Installation of Environmental Horizontal Wells: AMH-6 and AMH-7 Installation Report CDM Federal Programs Corporation

May 5, 1993
Westinghouse Savannah River Company Subcontract No. AA46325P

Task Order No. 10

\subsection{GEOLOGIC SETTING}

\subsection{Regional Setting}

The SRS is located in the Atlantic Coastal Plain Physiographic Province (Fig. 3-1). Within the Atlantic Coastal Plain Province, the SRS lies on the Aiken Plateau (Fig. 3-2) which is bounded by the Savannah and Congaree Rivers. The surface of the Aiken Plateau is dissected by streams and is characterized by broad, interfluvial areas with narrow steep-sided valleys.

The Atlantic Coastal Plain is comprised of a wedge of southeast-dipping unconsolidated and semiconsolidated sediments which increase in thickness from zero at the Fall Line to more than 4,000 feet near the Atlantic Coast. These sediments range from Late Cretaceous (100 million years) to Holocene (present) in age and extend to the seaward edge of the Continental Shelf. The Atlantic Coastal Plain sediments generally consist of strata of gravel, sand, silt, clay, and limestone, which were deposited in a variety of fluvial, deltaic, and marine depositional environments. The base of the Atlantic Coastal Plain sediments lies unconformably on top of crystalline, metamorphic and granitic rocks in the northem portion of the SRS and on top of Triassic sediments, deposited in a rift basin, in the southern part of the SRS. The Atlantic Coastal Plain sediments have been extensively studied at the SRS, and many lithologic and hydrostratigraphic names have been applied to these sediments. Figure 3-3 illustrates a comparison of chronostratigraphic, lithostratigraphic, and hydrostratigraphic units. For the purpose of this report, the A/M-Area hydrogeologic setting is described using hydrostratigraphic nomenclature, and the vadose zone, where the horizontal drilling occurred, will be described using lithostratigraphic nomenclature.

\subsection{A/M Area Hydrogeologic and Hydrostratigraphic Setting}

In the A/M Area, the Atlantic Coastal Plain hydrogeologic province consists of the FloridanMidville Aquifer System which includes the McQueen Branch Aquifer, the Crouch Branch Aquifer, and the Steed Pond Aquifer (Fig. 3-4).

The majority of the monitoring wells within the A/M Area are constructed in the water-bearing sediments overlying the McQueen Branch Confining Unit. The Crouch Branch Aquifer, which overlies the McQueen Branch Confining Unit, is continuous beneath all of the A/M Area. Beneath the Integrated Demonstration Site at MSB-2, the top of the Crouch Branch Aquifer lies approximately 275 feet below land surface. The Crouch Branch Confining Unit separates the underlying Crouch Branch Aquifer from the overlying Steed Pond Aquifer. Within the central and southem portions of the A/M Area, the Crouch Branch Confining Unit, from its base to the top of the unit, can be subdivided into "lower clay" and "upper clay" confining zones separated by a "middle sand" aquifer zone. The entire Crouch Branch Confining Unit thins in a northerly direction, and when the "upper clay" confining zone is absent, the "middle sand" aquifer zone merges with the overlying Steed Pond Aquifer north of the M-Area Settling Basin to form the Hollow Creek Aquifer. Within the southern to central portions of the AM Area, the Steed Pond Aquifer, from its base to the top of the aquifer, includes the "Lost Lake" aquifer zone, the "green clay" confining zone, and the "M-Area" aquifer zone.

Overlying the "M-Area" aquifer zone is the vadose zone. At the M-Area Settling Basin, the depth to the bottom of the vadose zone (water table) is approximately 130 feet below ground 
Demonstration of River Crossing Technology for Installation of Environmental Horizontal Wells: AMH-6 and AMH-7 Installation Report CDM Federal Programs Corporation

May 5, 1993
Westinghouse Savannah River Company

Subcontract No. AA46325P

Task Order No. 10

surface. The vadose zone underlying the M-Area Settling Basin includes portions of the Santee Formation, Dry Branch Formation, Tobacco Road Formation, and the "Upland unit". AMH-6 and AMH-7 were installed completely within the vadose zone below the M-Area Settling Basin and thus the only geologic formations that will be characterized in this report are those that comprise the vadose zone. These formations are described from the base of the vadose zone to ground surface.

\subsubsection{Santee Formation}

In the A/M Area, the Santee Formation varies in thickness from 30 to 45 feet. Below the M-Area Settling Basin, the Santee Formation is 43 feet thick at MHT-3C, and the top of the formation lies 103 feet below land surface. It is composed of brown, tan, and yellowish orange, fine to coarse, poorly to well-sorted sands and interbedded with clayey sand, sandy clay, and clay. It is distinguished from the cleaner sands of the overlying Dry Branch Formation by a higher gamma-ray count on geophysical logs. Underlying the M-Area Settling Basin, the Santee Formation is partially saturated with a static water level of approximately 130 feet below ground surface.

Both AMH-6 and AMH-7 were screened in the Santee Formation. Figures 3-5 and 3-6 illustrate the relationship of the installed screen zones to the formations and the zone of saturation. Drilling became difficult during the installation of both AMH-6 and AMH-7 as each borehole was emerging from the radius of curvature. This point appears to correspond to the contact between the Santee Formation and the overlying Dry Branch Formation. The Santee Formation has a higher clay content and numerous clay stringers in comparison to the relatively clean sands of the Dry Branch Formation. This increase in clay content probably accounted for the difficulty in penetration of the drill bit.

\subsubsection{Dry Branch Formation}

The Dry Branch Formation crops out in stream valleys, and the thickness varies from 0 to 110 feet in A/M Area wells. Below the M-Area Settling Basin, the Dry Branch Formation is 35 feet thick at MHT-3C, and the top of the formation lies 68 feet below ground surface. Sand of the Dry Branch Formation probably accumulated in a shallow marine environment. Jacksonian (Late Eocene) fossils have been found in the formation in downdip SRS wells, and the specific formation was traced into the $\mathrm{A} / \mathrm{M}$ Area by correlating it with lithologic and geophysical logs.

The Dry Branch Formation is composed of orange, brown, tan, and yellow, fine to coarse, poorly to well-sorted quartz sand. Pebbly layers are common, and induration is slight to moderate. The Twiggs Clay Member of the Dry Branch Formation (Fig. 3-3) is difficult to map within the AMArea, but clay that is lithologically similar to the Twiggs Clay Member is present at various stratigraphic intervals within the Dry Branch Formation. This clay lithofacies, interbedded with sand and clayey sand, which is characterized as tan, light gray, and brown, ranges from 12 to 34 feet thick and occurs at approximately 80 feet below ground surface beneath the M-Area Settling Basin (Science Applications International Corporation [SAIC], 1992) but is not laterally continuous over long distances. It has been referred to as the "tan clay" in previous SRS reports and as the "270-ft clay" by Eddy and others (1991). The top of the Dry Branch Formation is identified on geophysical logs where a low gamma-ray count in the cleaner sand of the Dry Branch Formation sharply increases in the more 
Demonstration of River Crossing Technology for Installation of Environmental Horizontal Wells: AMH-6 and AMH-7 Installation Report CDM Federal Programs Corporation May 5, 1993
Westinghouse Savannah River Company

Subcontract No. AA46325P

Task Order No. 10

argillaceous sand of the Tobacco Road Formation. On most lithologic logs, the contact, which is probably conformable, is marked by an increase in silt and clay percentage. The Dry Branch Formation and the overlying formations are unsaturated beneath the M-Area Settling Basin.

\subsubsection{Tobacco Road Formation}

The Tobacco Road Formation crops out in several places in the A/M Area. The formation has a higher silt and clay content and thus a lower permeability than the Dry Branch Formation. The Tobacco Road Formation was probably deposited in a shallow marine environment and has been dated as late Jacksonian (late Late Eocene) downdip from the SRS in Georgia (Huddleston and Hetrick, 1985). Nystrom and Willoughby (1982) have traced the formation into the vicinity of the $\mathrm{A} / \mathrm{M}$ Area by correlation of outcrops and have dated it as Claibornian, not Jacksonian.

Beneath the M-Area Settling Basin, the Tobacco Road Formation is 15 feet thick at MHT-3C, and the top of the formation lies 53 feet below ground surface. The top of the Tobacco Road Formation is identified where comparatively well-sorted sand is overlain by more poorly sorted sand, pebbly sand, and clay of the "Upland unit". The Tobacco Road Formation is orange, red, brown, yellow, tan, and purple. Fine to coarse, poorly to well-sorted sands compose almost the entire formation. Pebbly layers are common, especially near the base. Clay clasts are fairly common, and clay layers ranging from 2 to 10 feet thick have been identified underlying the M-Area Settling Basin (SAIC, 1992). This unit is referred to as the "300-ft clay" by Eddy and others (1991).

\subsection{4 "Upland Unit"}

The "Upland unit" unconformably overlies the Tobacco Road Formation. The South Carolina Geological Survey has been mapping it as the informally named "Upland unit" (Nystrom and Willoughby, 1982). It partially corresponds to sediments previously mapped at the SRS as the Hawthorn Formation (Siple, 1967). The unit caps higher areas in much of the southwestern Coastal Plain of South Carolina and is a deposit of poorly-sorted, clayey, silty, pebbly, and cobbly quartz sand, conglomerate, and clay which show significant lateral and vertical variation.

In the $\mathrm{A} / \mathrm{M}$ Area, these sediments are yellow, orange, purple, red, brown, and tan, mostly fine to very coarse, clayey, silty quartz sand beds. They are locally pebbly with layers of conglomerate and are very poorly to poorly sorted, moderately indurated. Weathered feldspar grains are abundant in places. Clay lenses interbedded with these sands are laterally discontinuous. Thickness of the "Upland unit" varies from 0 to approximately 60 feet. The sediments, which have low permeability, were probably deposited in high energy fluvial channels, point bars, floodplains, and abandoned channels. The "Upland unit" has not been dated paleontologically, but it may correlate with the Miocene Altamaha Formation in Georgia (Nystrom et al., 1986).

Underlying the M-Area Settling Basin, the "Upland unit" is 53 feet thick at MHT-3C. Locally the "Upland unit" is characterized as a reddish orange, brown, and purple, poorly sorted gravelly sand and clay. The sandy units have a speckled appearance (SAIC, 1992). Only a few clay layers exceed one foot in thickness. Textural evidence exists indicating that many of 
Demonstration of River Crossing Technology for Installation of Environmental Horizontal Wells: AMH-6 and AMH-7 Installation Report CDM Federal Programs Corporation

May 5, 1993
Westinghouse Savannah River Company Subcontract No. AA46325P Task Order No. 10

the one-foot intervals logged as clay and sandy clay, in the lower portions of this unit, are cobble- to boulder-sized clasts of clay eroded from the underlying sediments or small lenticular clay lenses (SAIC, 1992).

During the installation of both AMH-6 and AMH-7, a dense, clayey horizon was encountered at approximately 25 feet below ground surface within the "Upland Unit". The density of this clay horizon slowed the spud jet penetration to nearly the point of rejection and caused both boreholes to be deflected horizontally. Figures 3-5 through 3-10 define the trace of AMH-6 and AMH-7 as installed below the M-Area Settling Basin as well as the first abandoned attempt at installing AMH-6 both in plan and in cross section. 
Demonstration of River Crossing Technology for Installation of Environmental Horizontal Wells: AMH-6 and AMH-7 Installation Report CDM Federal Programs Corporation

May 5, 1993
Westinghouse Savannah River Company Subcontract No. AA46325P Task Order No. 10

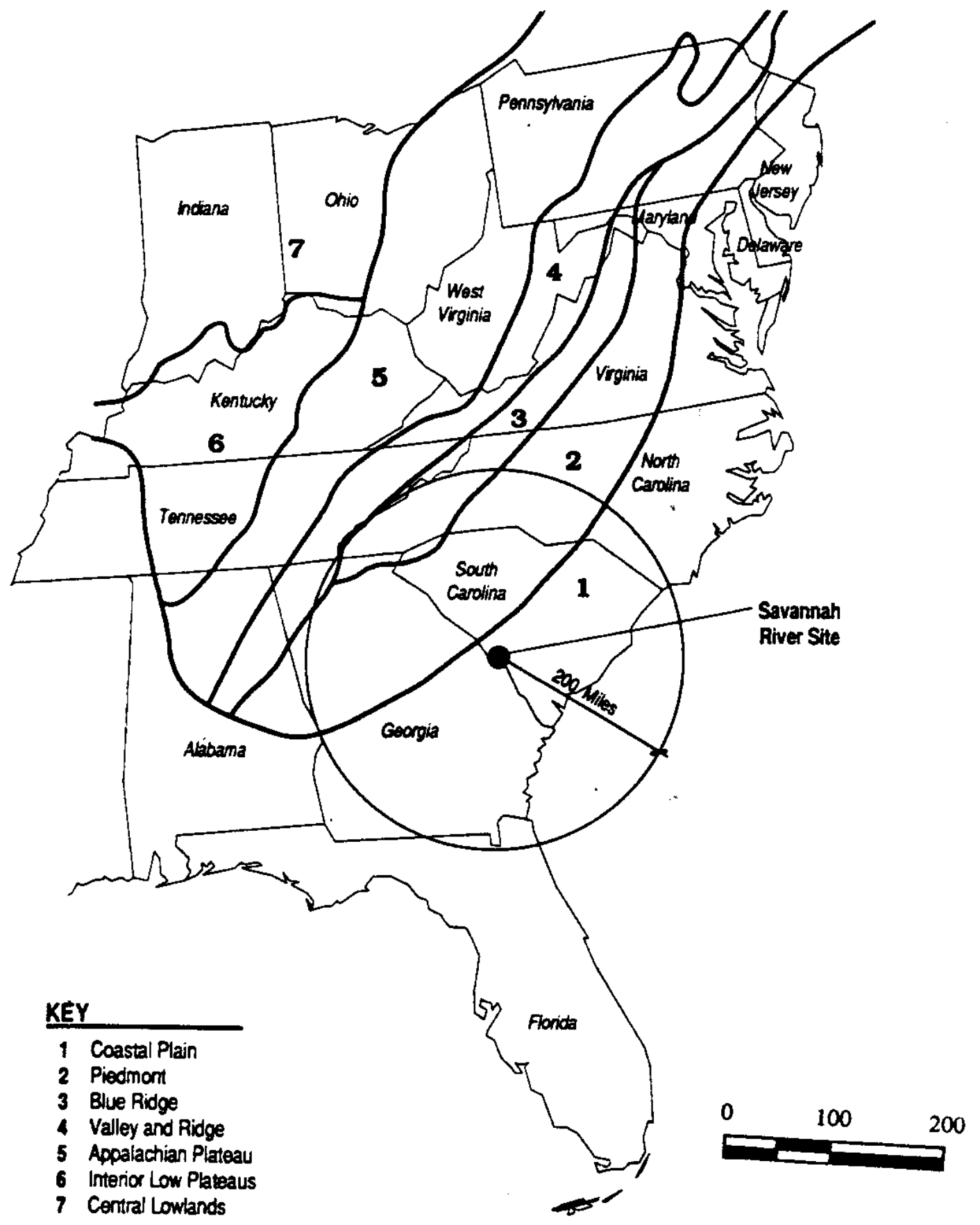

SOUACE: Water Resources Commission Report, Number 155, 1989

Figure 3-1. Physiographic Provinces of the Eastern United States 
Demonstration of River Crossing Technology for Installation of Environmental Horizontal Wells: AMH-6 and AMH-7 Installation Report CDM Foderal Programs Corporation

May 5, 1993
Westinghouse Savannah River Company Subcontract No. AA46325P Task Order No. 10

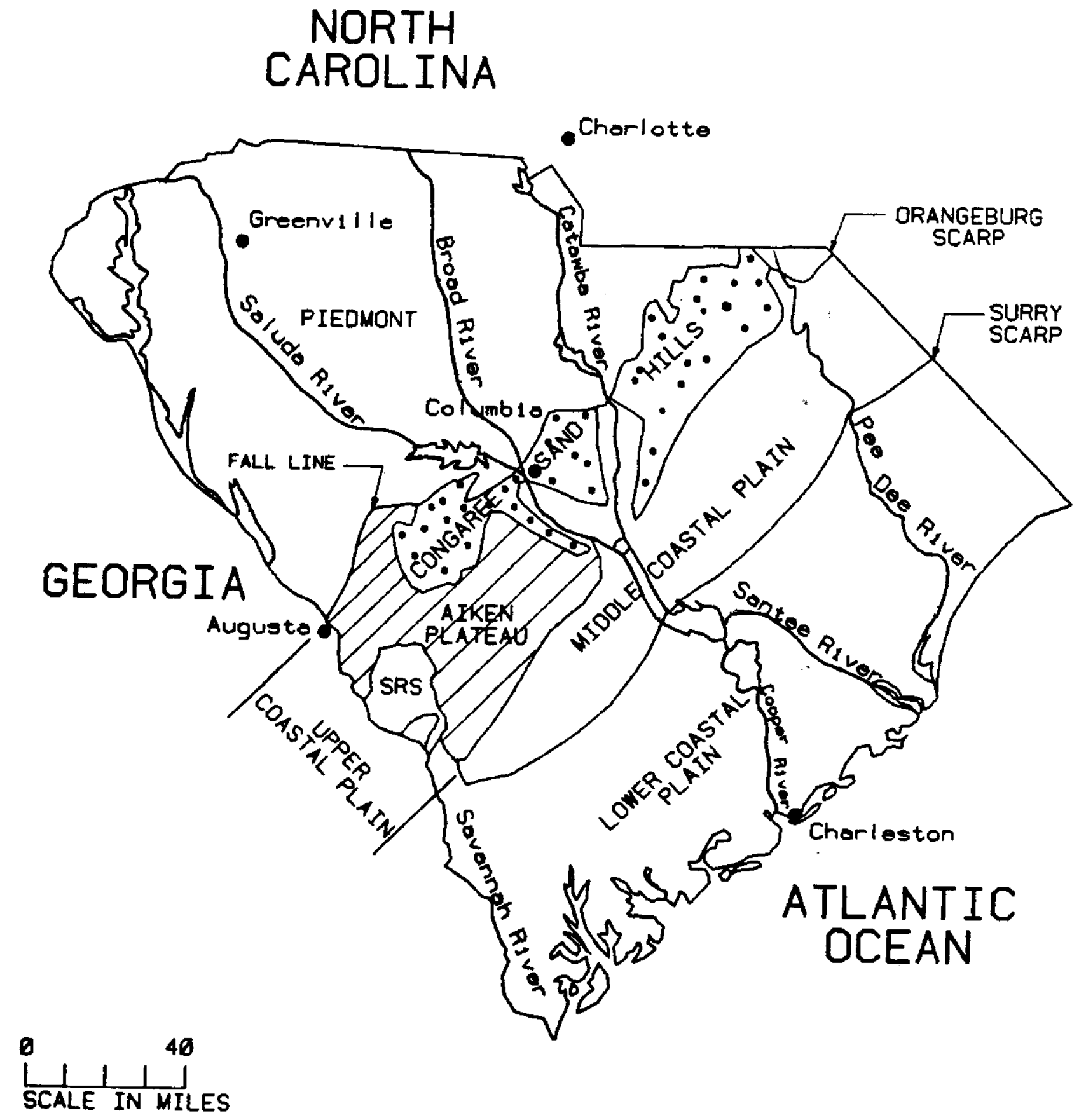

Figure 3-2. Physiographic Subprovinces of the South Carolina Coastal Plain 


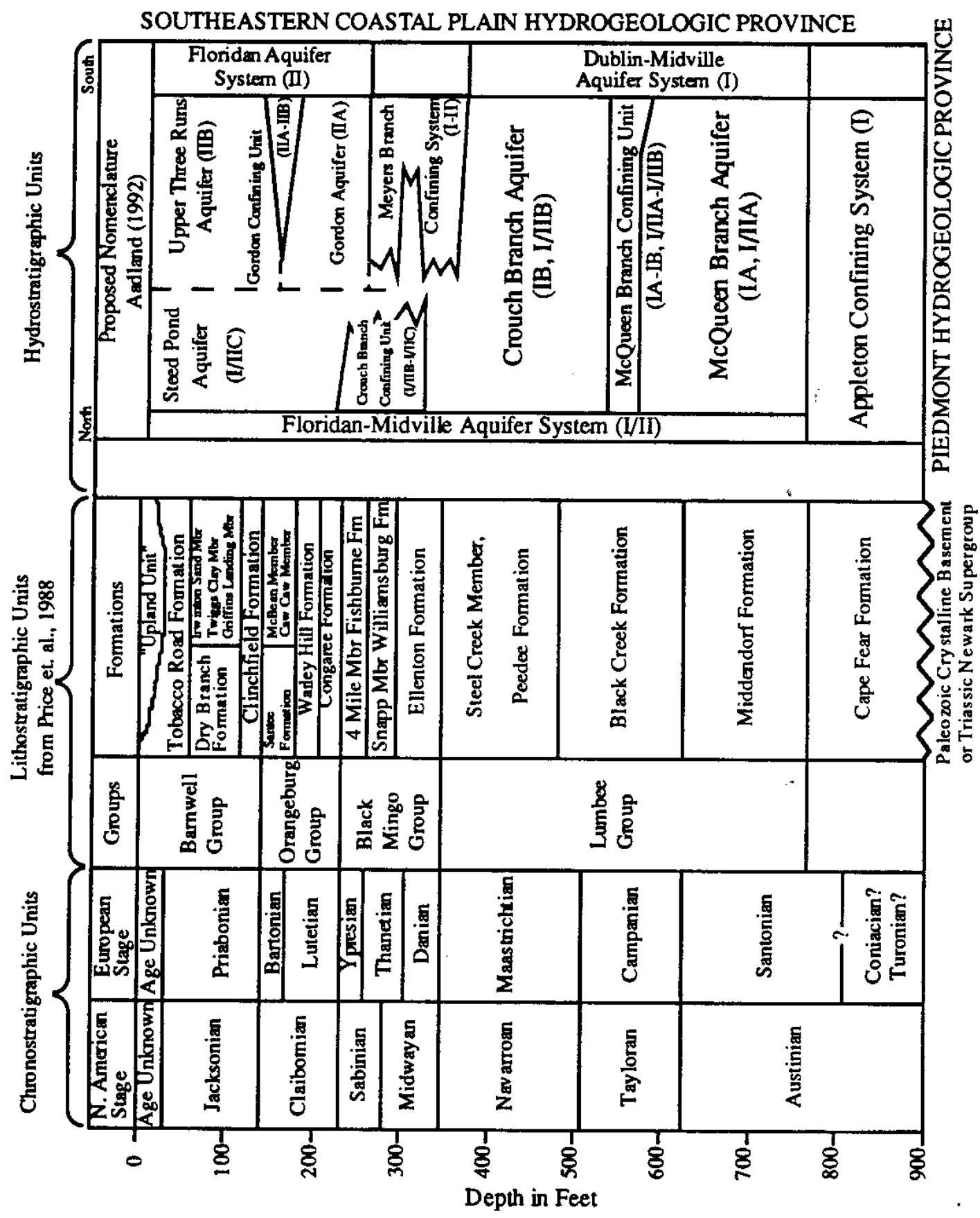

Figure 3-3. Comparison of Chronostratigraphic, Lithostratigraphic, and Hydrostratigraphic Units at the SRS 
Demonstration of River Crossing Technology for Installation of Environmental Horizontal Wells: AMH-6 and AMH-7 Installation Report CDM Federal Programs Corporation May 5, 1993
Westinghouse Savannah River Company Subcontract No. AA46325P Task Order No. 10

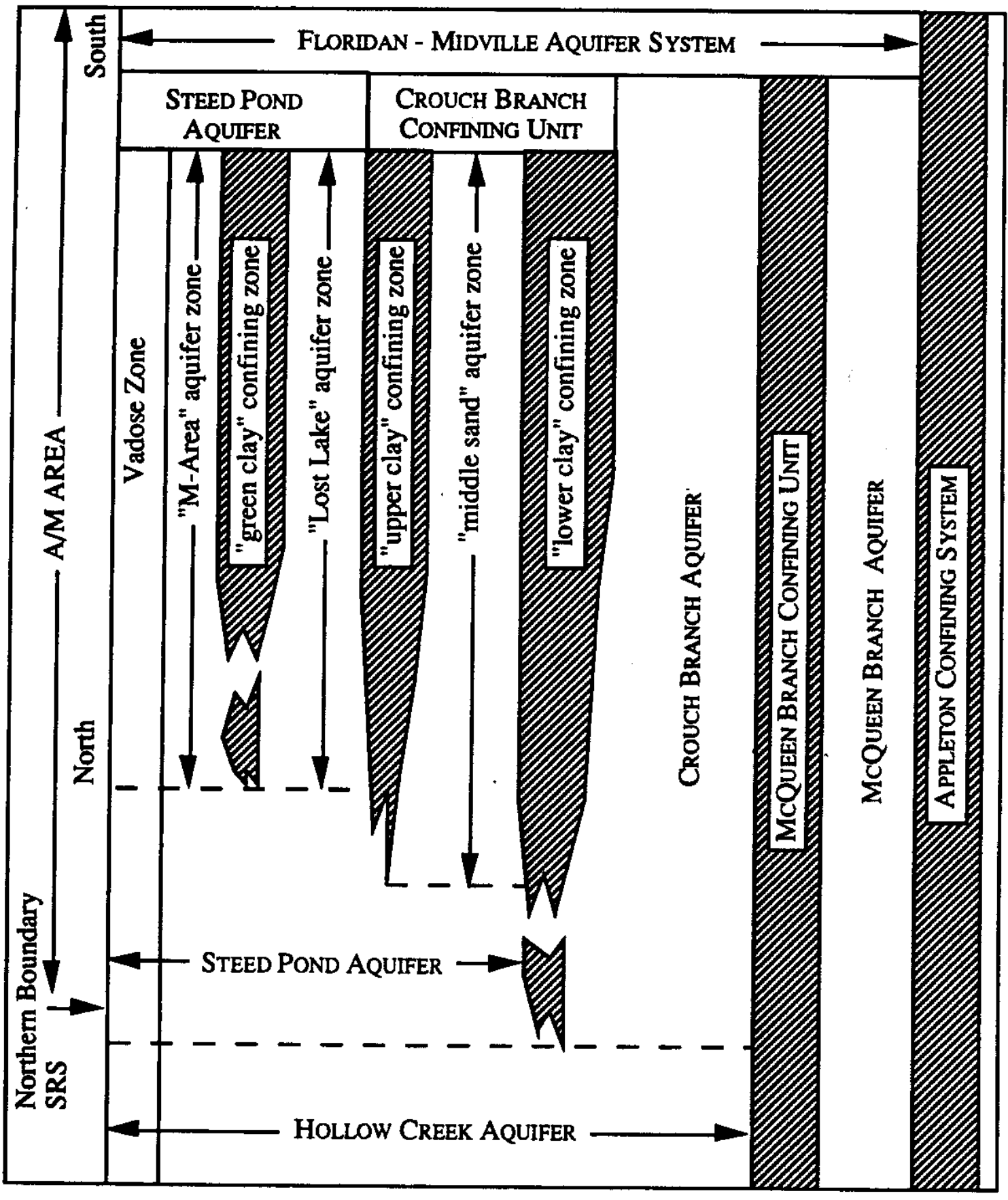

Figure 3-4. Hydrostratigraphic Chart for the $\mathbf{A} / \mathbf{M}$ Area 
Demonstration of River Crossing Technology for Installation of Environmental Horizontal Wells: AMH-6 and AMH-7 Installation Report CDM Federal Programs Corporation

May 5, 1993
Westinghouse Savannah River Company Subcontract No. AA46325P

Task Order No. 10

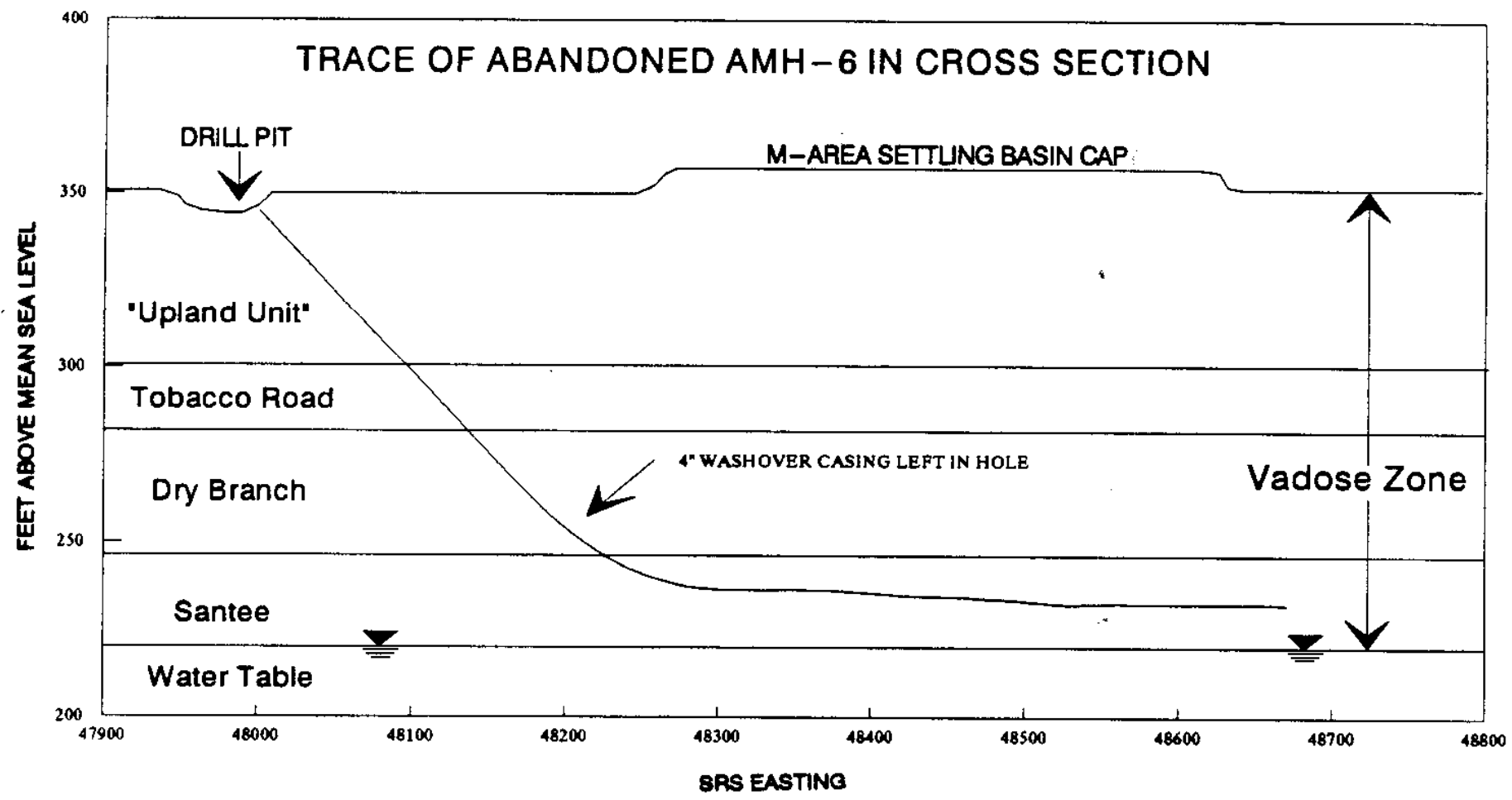

Figure 3-5. Trace of Abandoned Borehole AMH-6 in Cross Section with Relation to Geologic Units 
Demonstration of River Crossing Technology for Installation of Environmental Horizontal Wells: AMH-6 and AMH-7 Installation Report CDM Federal Programs Corporation

May 5, 1993
Westinghouse Savannah River Company Subcontract No. AA46325P Task Order No. 10

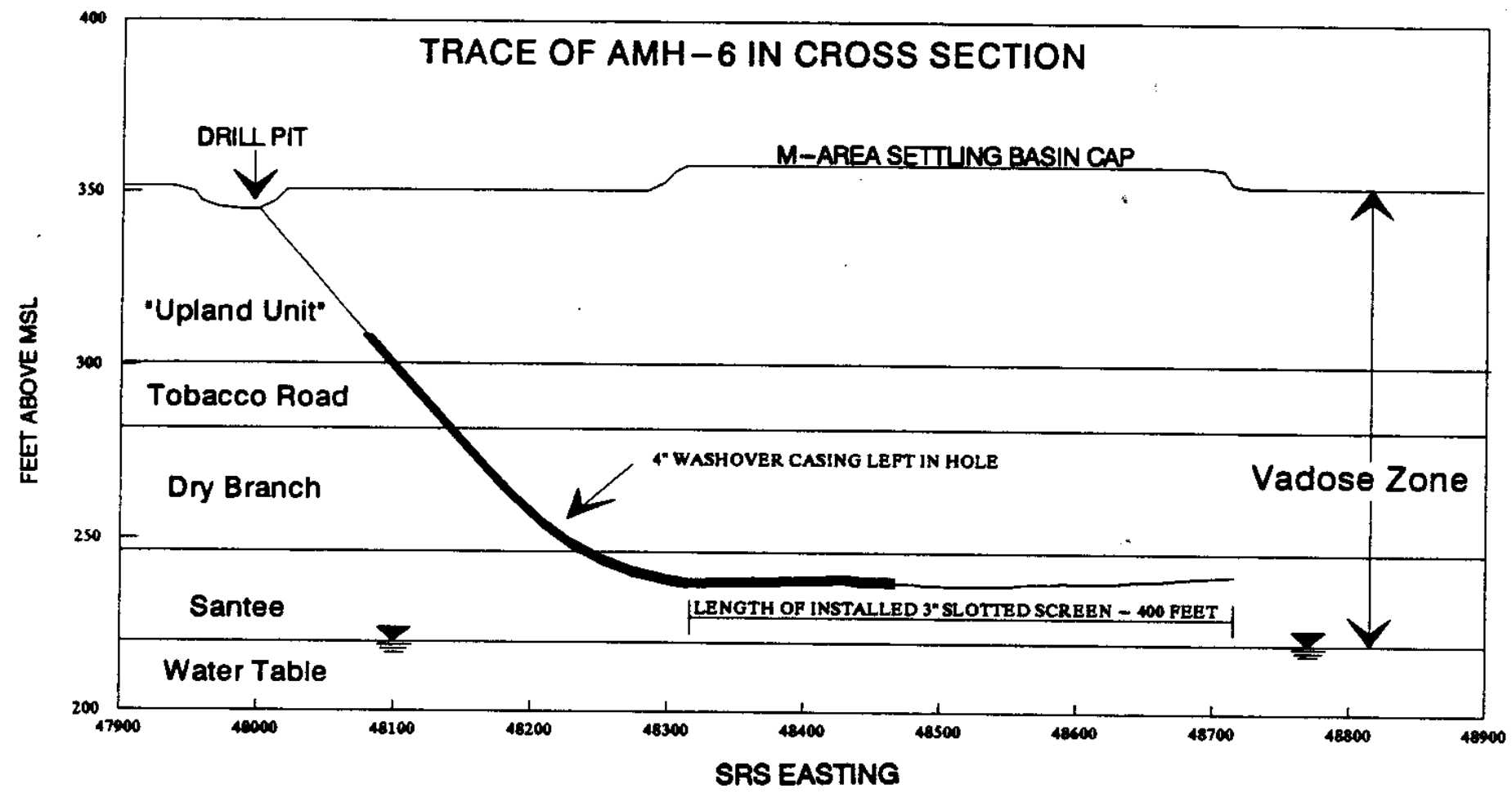

Figure 3-6. Trace of AMH-6 as Installed in Cross Section with Relation to Geologic Units 
Demonstration of River Crossing Technology for Installation of Environmental Horizontal Wells: AMH-6 and AMH-7 Installation Report CDM Federal Programs Corporation May 5, 1993
Westinghouse Savannah River Company Subcontract No. AA46325P Task Order No. 10

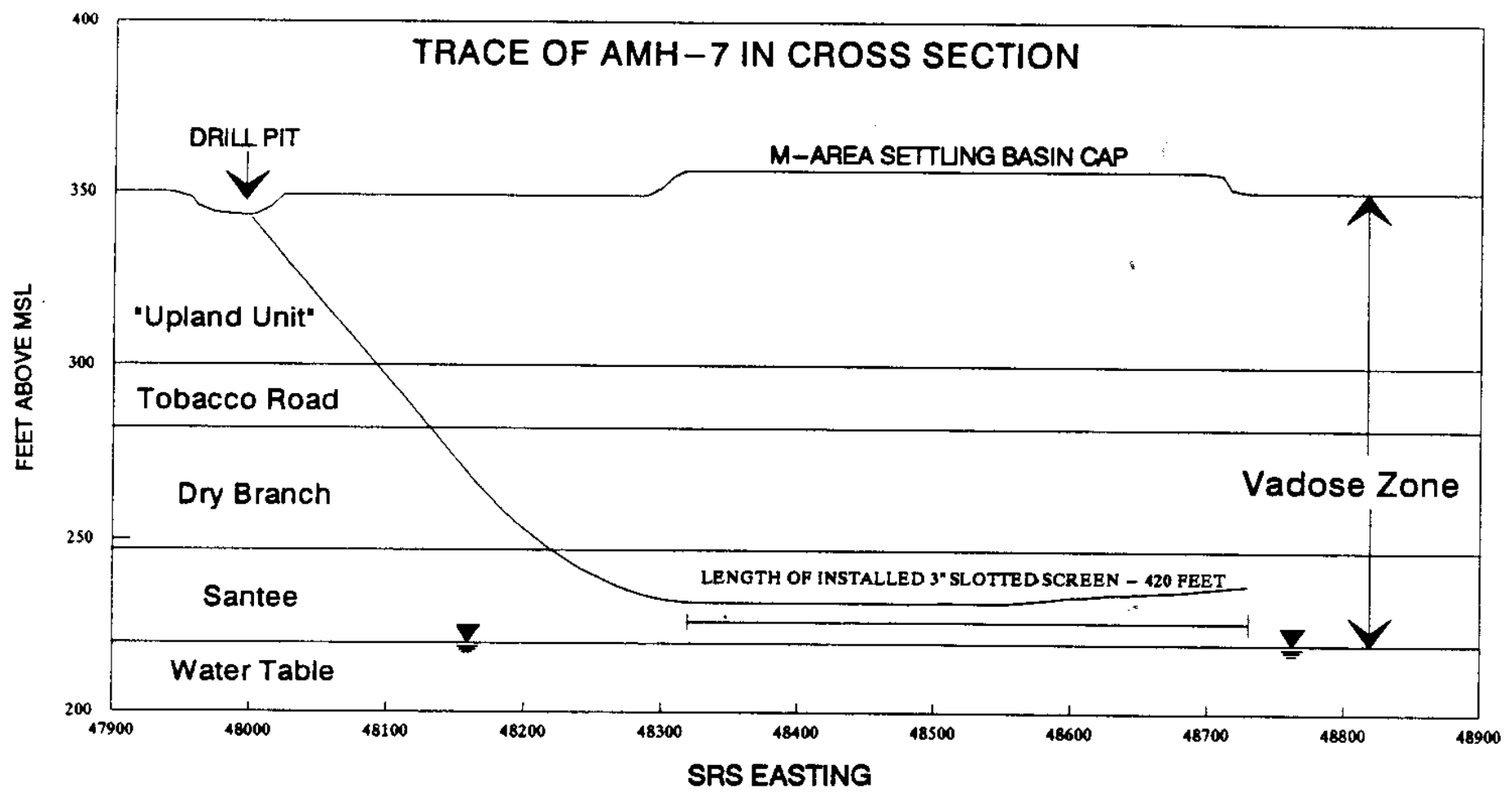

Figure 3-7. Trace of AMH-7 as Installed in Cross Section with Relation to Geologic Units 
Demonstration of River Crossing Technology for Installation of Environmental Horizontal Wells: AMH-6 and AMH-7 Installation Report CDM Federal Programs Corporation

May 5, 1993
Westinghouse Savannah River Company Subcontract No. AA46325P Task Order No. 10

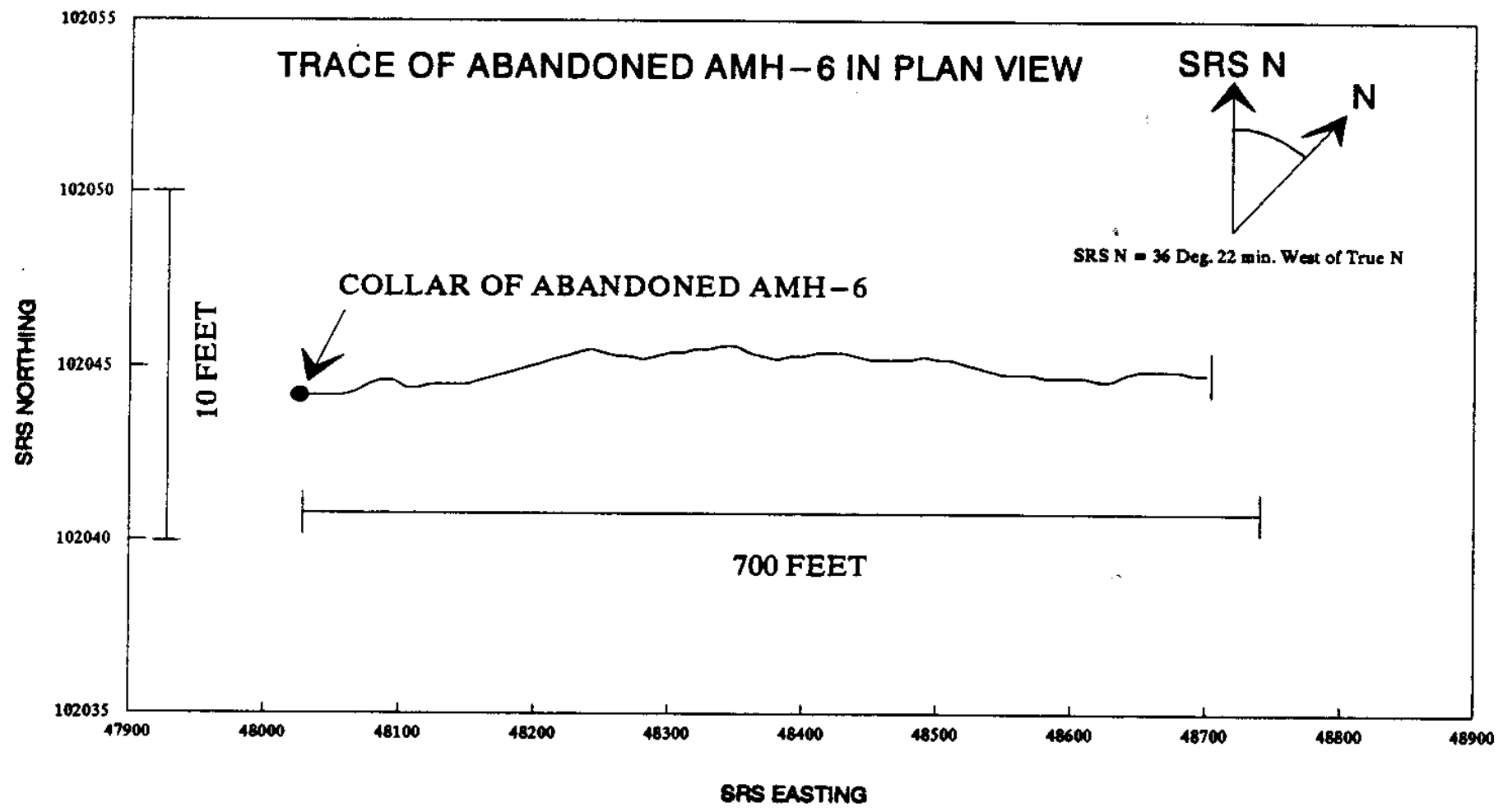

Figure 3-8. Trace of Abandoned Borehole AMH-6 in Plan View 
Demonstration of River Crossing Technology for Installation of Westinghouse Savannah River Company Environmental Horizontal Wells: AMH-6 and AMH-7 Installation Report CDM Federal Programs Corporation Subcontract No. AA46325P May 5, 1993

Task Order No. 10

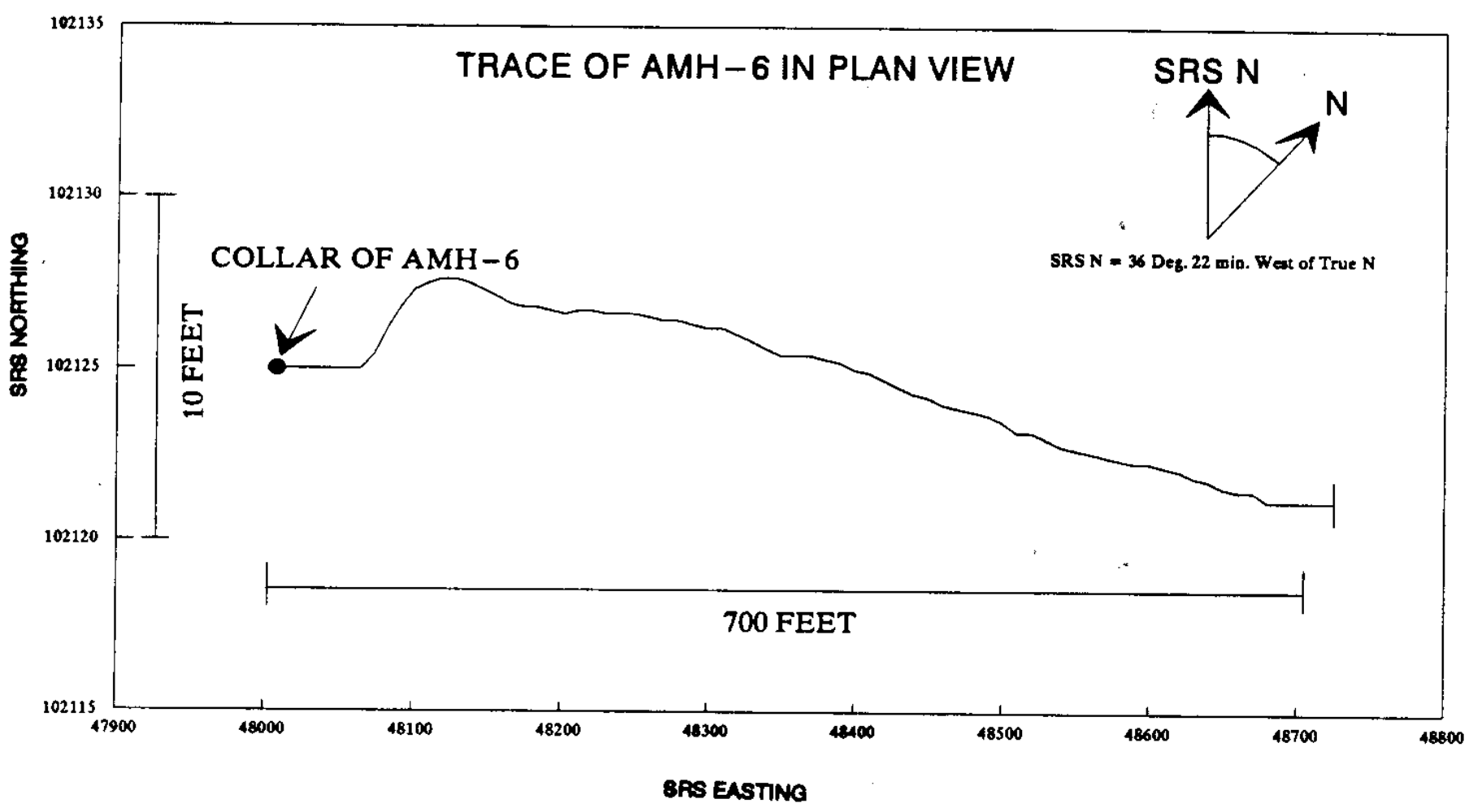

Figure 3-9. Trace of AMH-6 as Installed in Plan View 
Demonstration of River Crossing Technology for Installation of Westinghouse Savannah River Company Environmental Horizontal Wells: AMH-6 and AMH-7 Installation Report CDM Federal Programs Corporation

Subcontract No. AA46325P

May 5, 1993

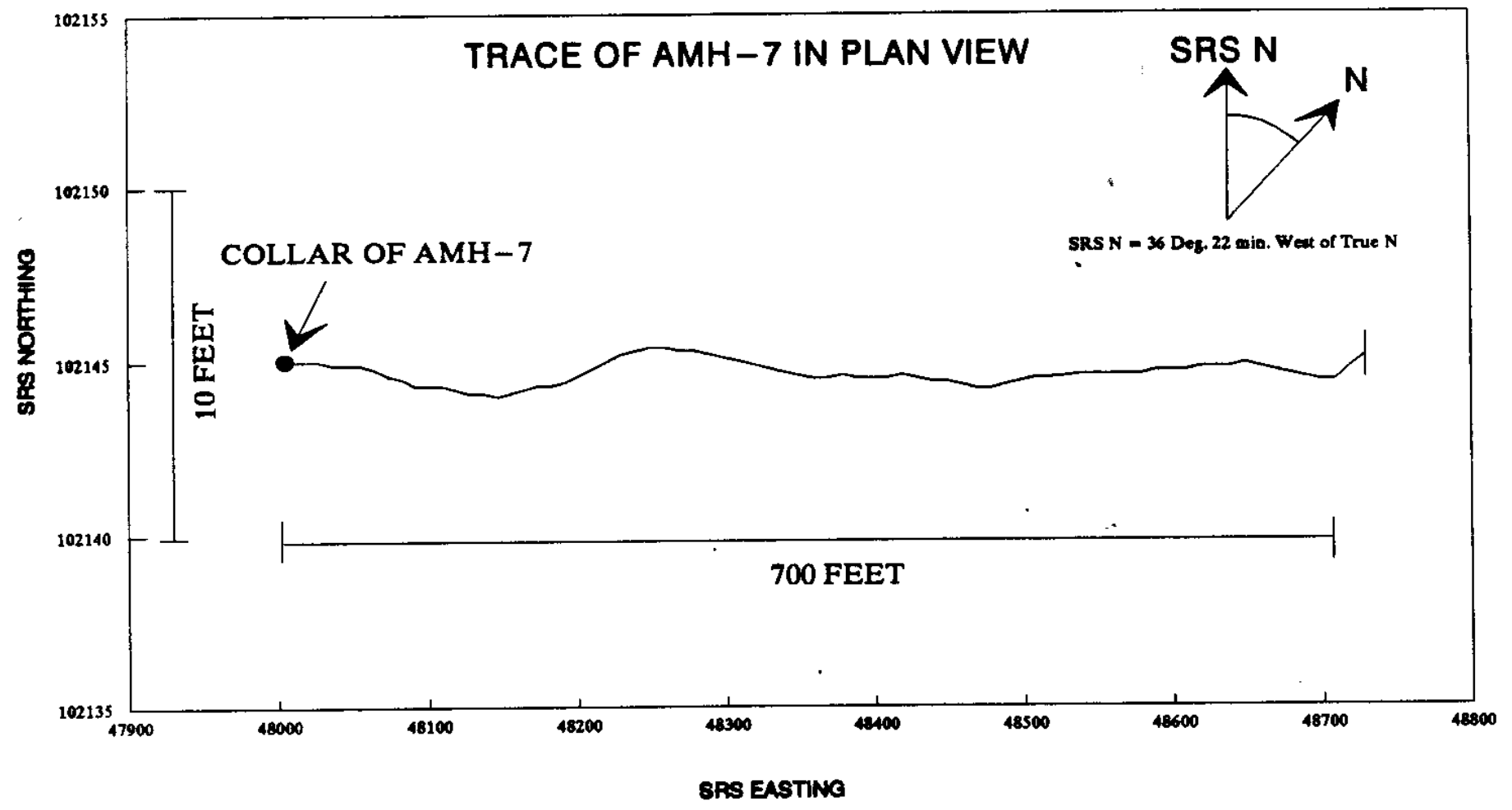

Figure 3-10. Trace of AMH-7 as Installed in Plan View 
Demonstration of River Crossing Technology for Installation of Environmental Horizontal Wells: AMH-6 and AMH-7 Installation Report CDM Federal Programs Corporation

May 5, 1993
Westinghouse Savannah River Company Subcontract No. AA46325P Task Order No. 10

\subsection{DRILLING SYSTEM}

A river crossing industry directional drilling rig was used for this project. River crossing industry directional drilling rigs range in size from small trailer mounted drilling rigs that can be pulled by a pick-up truck to large semi-tractor trailer mounted drilling rigs capable of drilling large (up to 60-inches in diameter) boreholes thousands of feet. Horizontal wells AMH-6 and AMH-7 were installed using a medium-sized river crossing directional drilling rig.

\subsection{Equipment Used}

\subsubsection{Drilling Rig}

The MC-90 drilling rig (Fig. 4-1) is a top drive hydraulic mud rotary rig with a high thrust and rotational torque capacity. The maximum thrust power of the drilling rig is 47,000 pounds (lbs). The maximum pullback capacity is $120,000 \mathrm{lbs}$. The maximum spindle rotational speed of the drilling rig is 200 revolutions per minute (rpms) with a maximum spindle torque of 6,000 foot-pounds (ft-lbs). The maximum mud pressure of the power source is 2500 pounds per square inch (psi) generated from 234 horsepower. The drilling rig is able to turn drill pipe in sizes ranging from the smallest available size to 12 inches in diameter for distances of up to 2,000 feet in most soil conditions. The diameter and/or length capability may be significantly reduced where formations contain 30 percent or more gravels. The maximum drill rod length for the drilling rig is 10 feet. The drilling operations are controlled from a console mounted on the right side of the drilling rig.

The drilling rig is track driven and has two adjustable drilling platforms that allow the driller to accurately adjust the drilling angle. The track drive and the drilling platform are controlled from a console located at the rear of the drilling rig. The approximate operating weight of the rig is $8,000 \mathrm{lbs}$.

At the front of the drilling rig there is a piston-driven ram that is used to anchor the drilling rig. The drilling rig anchor is created by welding the ram to a mass of metal buried in the ground (a "dead man"). During this project the "dead man" consisted of two 10-foot sections of fourinch drill pipe driven vertically into the ground.

\subsubsection{Down-Hole Drilling Assembly}

The down-hole drilling assembly consists of a directional drilling tool and a steering tool contained in a non-magnetic housing (Fig. 4-2). The total length of the down-hole drilling assembly is approximately 15 feet. All components of the down-hole drilling assembly, including the closest three pieces of drill stem, are constructed of non-magnetic steel to prevent magnetic interferences with the steering tool.

\section{Drilling Tool}

CEC proposed to use one of two types of drilling tools depending on the hardness of the materials encountered. A hydraulic spud jet, designed to penetrate soft alluvial formations (sands, clayey sands, etc.) similar to the types of sediments present at the M-Area Settling 
Demonstration of River Crossing Technology for Installation of Environmental Horizontal Wells: AMH-6 and AMH-7 Installation Report CDM Federal Programs Corporation

May 5, 1993
Westinghouse Savannah River Company

Subcontract No. AA46325P

Task Order No. 10

Basin, was planned as the primary drilling tool. An in-hole mud drilling motor was planned to be used if drilling conditions became too difficult for the hydraulic spud jet drilling tool.

The hydraulic spud jet drilling tool (Fig. 4-3) was equipped with a $2^{\circ}$ bend in the housing to provide directional drilling capabilities. When the drilling tool is pushed forward without rotation, the tool deviates in the direction of the angle of the tool. To drill without deviation the drilling tool is rotated as it is pushed forward; in this way the tool face does not have a preferred orientation, and the drilling tool advances along a straight path, as in the slant or horizontal sections of the borehole. The tool face orientation is monitored by the steering

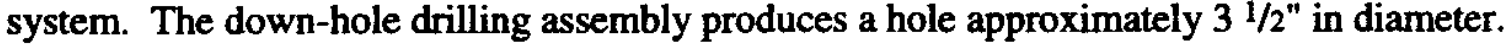

\section{Steering System}

The orientation and location of the pilot bit was constantly monitored with a "real time" magnetic guidance system (MGS) (Fig. 4-4). This MGS enabled the driller to steer the pilot bit into place and ensure proper borehole alignment and elevation. The MGS was supplied by Sharewell, Inc., a subcontractor to CEC. The MGS enabled the driller to guide the pilot bit by providing immediate gravitational and magnetic information on tool face orientation, azimuth (horizontal location) and inclination (vertical location). These raw data were transmitted to an interface unit at the surface from a down-hole sensor located immediately above the drilling tool or drill motor via a single conductor wire. The surface interface unit displayed tool face orientation, azimuth, and inclination readings. Knowledge of the length of the drill string, azimuth, and inclination allowed the driller to calculate the location of the down-hole sensor and thus the borehole path. Tool face orientation provides information used to determine the steering direction of the drilling tool. The MGS is a proven, accurate system and is hindered only by local magnetic interferences. If magnetic interferences are observed, then a secondary survey system is used. The secondary survey system was not required for this drilling project.

\subsubsection{Drill Rods and Bits}

The drilling method utilizes two drill strings. A small diameter drill string (pilot drill string) is used with the down-hole drilling assembly to drill the pilot hole, and a larger diameter drill string (washover drill string) is drilled over the pilot drill string (Fig. 4-5).

The pilot drill string was used to accurately place the pilot hole in the correct location. The pilot drill string is made up of $23 / 16^{\prime \prime}$ outside diameter (OD), 4130 heat-treated steel BCQ drill rods adapted from the mining industry. The length of the pilot drill string rods was limited to 10 feet by the size of the drilling rig.

The washover drill string was used to maintain borehole stability during installation of the horizontal well materials. The $41 / 2^{\prime \prime} \mathrm{OD}, 2160$ heat-treated steel washover pipe was drilled circumferentially over the $23 / 16^{\prime \prime}$ pilot string which served as a guide for the washover pipe until the total drilling distance was achieved (Fig. 4-5). CEC utilized a nine-inch bit for drilling in the washover pipe (Fig. 4-6). The length of the washover drill string rods was limited to 10 feet by the size of the drilling rig. 
Demonstration of River Crossing Technology for Installation of Environmental Horizontal Wells: AMH-6 and AMH-7 Installation Report CDM Federal Programs Corporation

May 5, 1993
Westinghóuse Savannah River Company Subcontract No. AA46325P Task Order No. 10

\subsection{Drilling Fluid System}

The drilling fluid system was typical of a recirculating mud rotary drilling operation. The system included: a mixing tank where the drilling fluid was mixed, a mud pumping system to pump the mud through the hydraulic spud jet, a mud pit to mechanically settle the coarser fraction of suspended drilling solids as it exits from the borehole, and a mud settling tank and desander to remove the finer sand remaining in suspension (Fig. 4-7).

The drilling fluid consisted of processed guar gum beans, ground into colloidal particles and mixed with water through a standard mixing jet hopper. Guar gum is a natural polymer that acts to increase the viscosity of the drilling fluid. With bentonite-based drilling fluids, the gel strength or carrying capacity (the size of particles remaining in suspension) is directly related to the viscosity of the drilling fluid. However, with a guar gum-based drilling fluid the gel strength is not directly related to viscosity. Therefore, the carrying capacity of a guar gumbased drilling fluid cannot be predicted by its viscosity. To increase the gel strength of the guar gum-based drilling fluid, the natural polymers must be linked together by an additive. The additive most commonly used is Borax. During this drilling project the guar gum carrying capacity was not enhanced with Borax and therefore drill cuttings were left in the borehole. The drilling fluid needed periodic reconditioning due to the length of the drilling program and was reconditioned by simply adding more guar gum. Guar gum-based drilling fluids biodegrade naturally within approximately two days.

\subsection{Drilling Procedures}

The drilling procedures consisted of setting up the drilling rig, drilling the borehole, and installing the horizontal well.

\section{Setting Up the Drilling Rig}

Setting up the drilling rig involved surveying the direction (azimuth) of the horizontal well, calibrating the steering tool along the azimuth of the horizontal, and setting up the drilling rig and mud system. The well entry locations were surveyed, and the azimuth of each horizontal well was delineated on the ground surface with stakes and cords. The steering tool was lined up on the horizontal well azimuth and calibrated to ensure proper orientation of the borehole.

Plastic sheeting ( 0.010 millimeter thick) was placed on the ground at the entry point and the drilling rig was then moved into place and lined up on the horizontal well azimuth (Fig. 4-8). The drilling platform was tilted to the proper entry angle, and a mud pit was constructed at the entry point. Plastic sheeting was also placed in the mud pit. The down-hole drilling assembly was placed on the drilling rig and drilled into the ground.

\section{Drilling the Borehole}

The borehole was constructed using a technique named "over-washing". The procedure required a pilot drill string and a washover drill string. The pilot drill string was advanced in stages and then drilled over (over-washed) by the washover drill string. The length of the stages were dictated by the drilling conditions; generally the length of the stage was from 100 feet to 200 feet. The one exception was the section between the kick-off point and the end of 
Demonstration of River Crossing Technology for Installation of Westinghouse Savannah River Company Environmental Horizontal Wells: AMH-6 and AMH-7 Installation Report CDM Federal Programs Corporation

Subcontract No. AA46325P

May 5, 1993

the curve. The pilot hole was always completely drilled in the curved section before the washover casing was advanced. Once the pilot hole reached the target measured depth and the washover drill string was advanced to the total measured depth, the pilot drill string was removed.

\section{Installing the Horizontal Well Materials}

The horizontal well string (the riser casing and well screen) was installed by screwing 20 -foot sections together and advancing them down inside the washover drill string by hand. Hydraulic pressure (drilling fluid) or mechanical pressure (the drilling rig) was used to advance the well string when resistance to the manual installation became too great to advance the well string. Once the well string was in place the washover drill string was retrieved, and the horizontal well was grouted and developed. Well development consisted of volume water flushing and air lifting drilling fluid and cuttings from the well until all cuttings were removed from the well screen.

\subsection{Operating Conditions}

The drilling plan called for the use of two crews with operations running 24 hours per day, seven days per week, as long as drill rods were in the ground. Approximately 30 minutes of shift overlap was allowed for crew shift transition. The night crew was informed they could work at a slower pace, if they felt it deemed necessary, to prevent safety hazards due to limited visibility.

The two extraction wells were designed to pass directly below the M-Area Settling Basin, above the water table in the vadose zone. Because the vadose zone below the basin contains various amounts of VOCs, namely trichloroethylene (TCE) and tetrachloroethylene (PCE), it was necessary to monitor the cuttings coming out of the ground. The SRTC representative utilized a hand-held photoionization detector (PID) for determining the amount of ambient VOCs within the drilling area. The health and safety plan designated worker clothing as Level D (hard hats, steel toe boots, coveralls). If PID readings for VOCs exceeded 10 parts per million (ppm), then the workers would be advised to move up to safety Level $C$ (respirator) while working in these areas. If VOCs readings reached $25 \mathrm{ppm}$, the workers would be required to move up to Level C protection. Readings were collected usually once a shift or as often as deemed necessary by the technical oversight. No VOC readings were recorded above $3 \mathrm{ppm}$, with average readings less than or equal to $1 \mathrm{ppm}$, for the duration of the project. 
Demonstration of tiver Crossing Technology for Installation of Envirommental Horizontal Wells: AMH-6 and AMH-7 Installation Report COM Federal Programs Corporation May 5, 1993
Westinghouse Savannah River Company Subcontract No. AA46325P Task Order No. 10

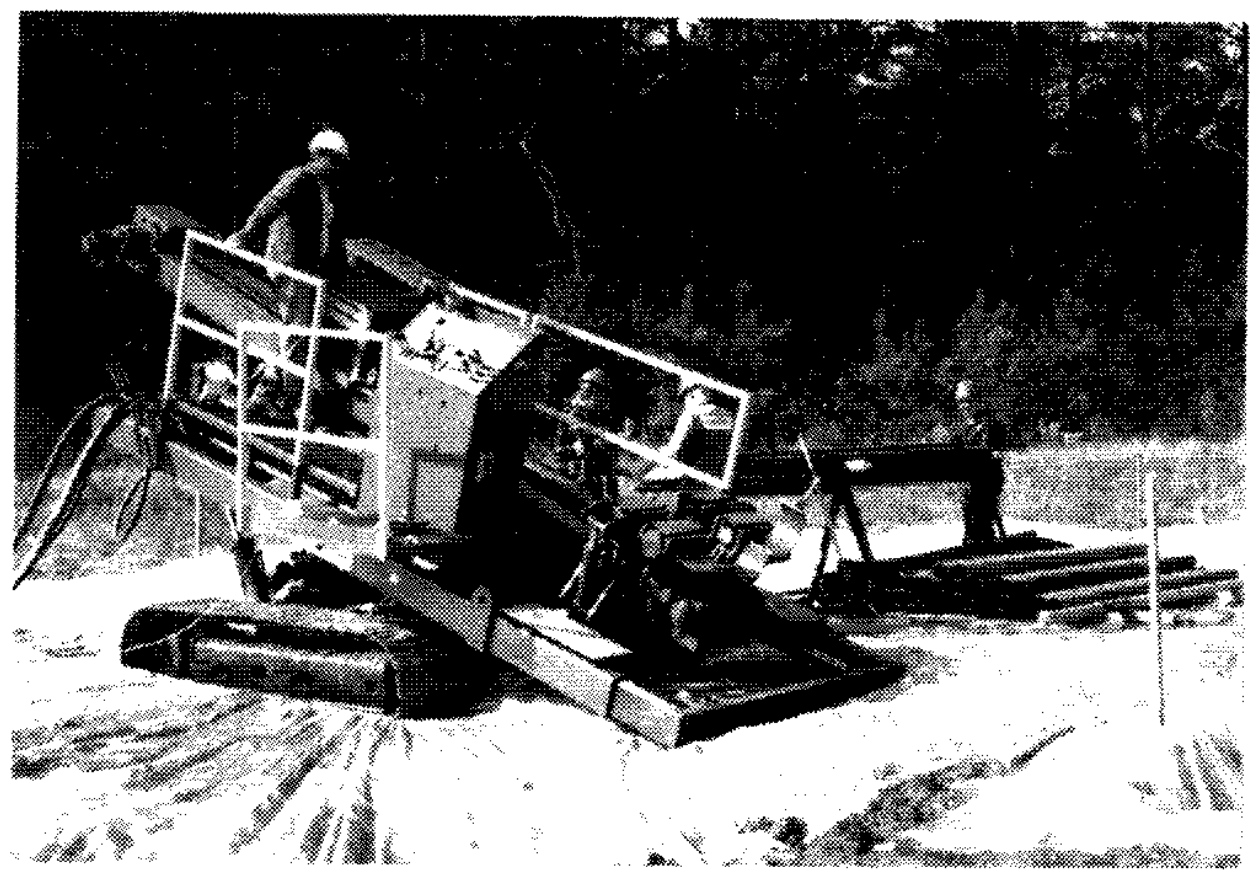

Oblique view of $\mathrm{MC}-90$ drilling rig .

Figure 4-1. Oblique View of MC-90 Drilling Rig 
Demonstration of River Crossing Technology for Installation of Environmental Horizontal Wells: AMH-6 and AMH-7 Installation Report CDM Federal Programs Corporation

May 5, 1993
Westinghouse Savannah River Company Subcontract No. AA46325P Task Order No. 10

\section{THIS PAGE INTENTIONALLY LEFT BLANK}


Demonstration of River Crossing Techuology for Installation of Environmental Horizontal Wells: AMH 6 and AMH-7 Installation Report CDM Federal Programs Corporation

May 5,1993
Westinghouse Savanuah River Company Subcontract No. AA46325P Task Order No. 10

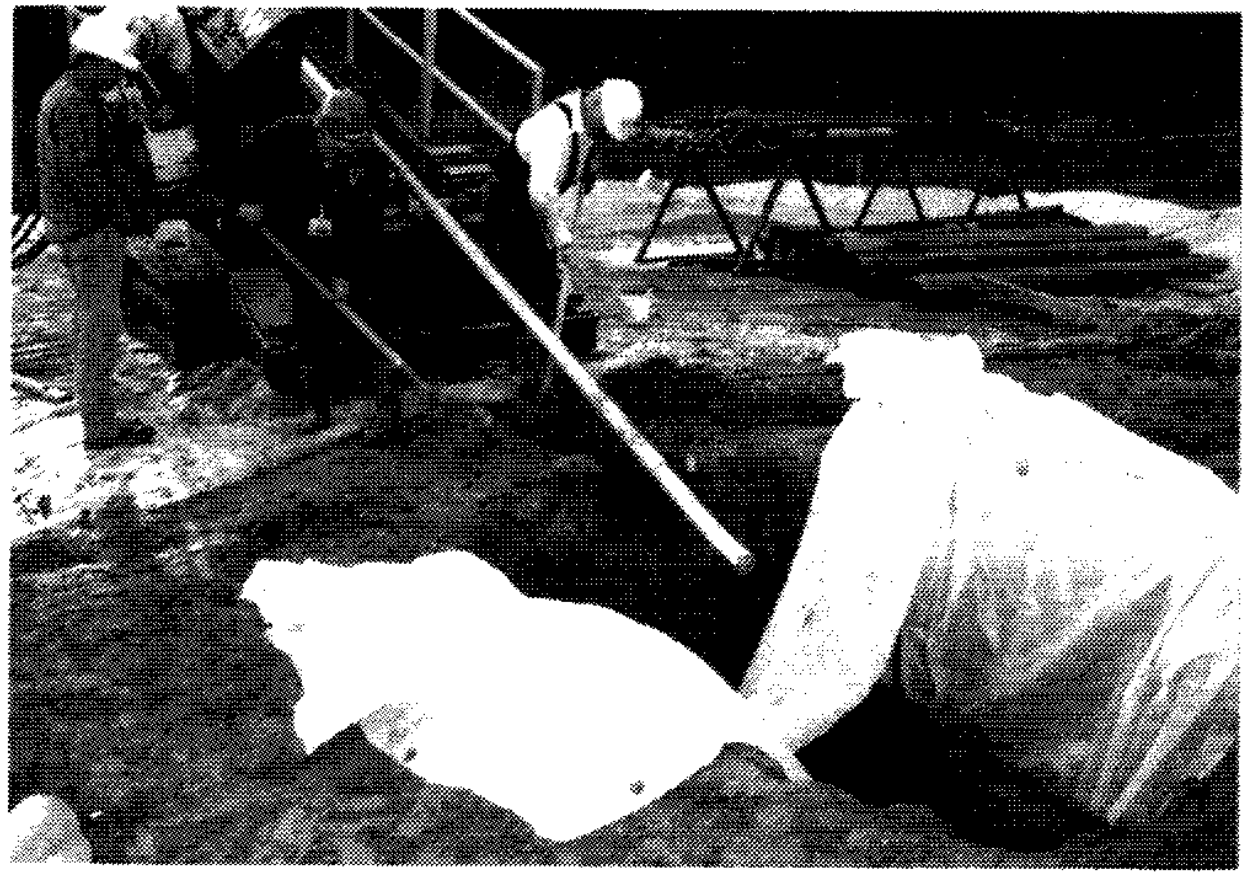

The down hole drilling assembly is shown on the drilling rig. The hydraulic spud-jet and bent sub-assembly are at the end of the down-hole assembly. The steering tool is located in the housing just behind the bent sub assembly. The drill sump is in the foreground.

Figure 4-2. Down-Hole Drilling Assembly 
Demonstration of River Crossing Technology for Installation of Environmental Horizontal Wells: AMH -6 and AMH-7 Installation Report CDM Federal Programs Corporation

May 5, 1993
Westinghouse Savannah River Company Subcontract No. AA46325 Task Order No. 10

\section{THIS PAGE INTENTIONALLY LEFT BLANK}


Demonstration of River Crossing Technology for lnstallation of Envirommental Horizontal Wells: AMH -6 and AMH-7 Installation Report CDM Federal Programs Corporation Miy 5,1993
Westinghouse Savannah River Company Subcontract No. AA46325P Task Order No. 10

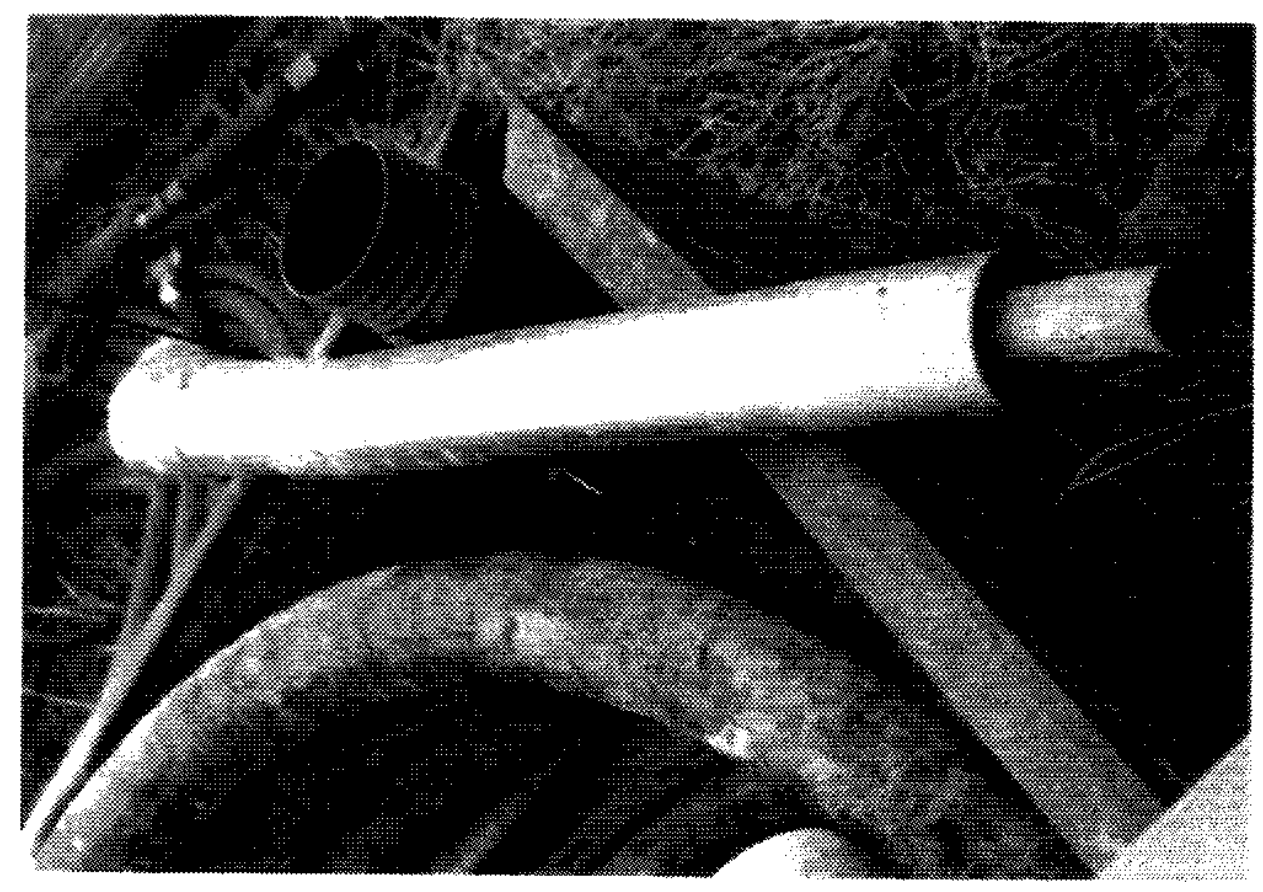

This hydraulic spud jet drilling tool was used throughout the duration of the project.

Figure 4-3. Directional Drilling Tool 
Demonstration of River Crossing Technology for Installation of Environmental Horizontal Wells: AMH-6 and AMH-7 Installation Report CDM Federal Programs Corporation

May 5, 1993
Westinghouse Savamah River Company Subcontract No. AA46325P Task Order No. 10

THIS PAGE INTENTIONALLY LEFT BLANK 
Demonstration of River Crossing Technology for Installation of Environmental Horizontal Wells: AMH-6 and AMH 7 Installation Report CDM Federal Programs Corporation

Westinghouse Savannah River Company May 5,1993

Subcontract No. AA46325P

Task Order No. 10

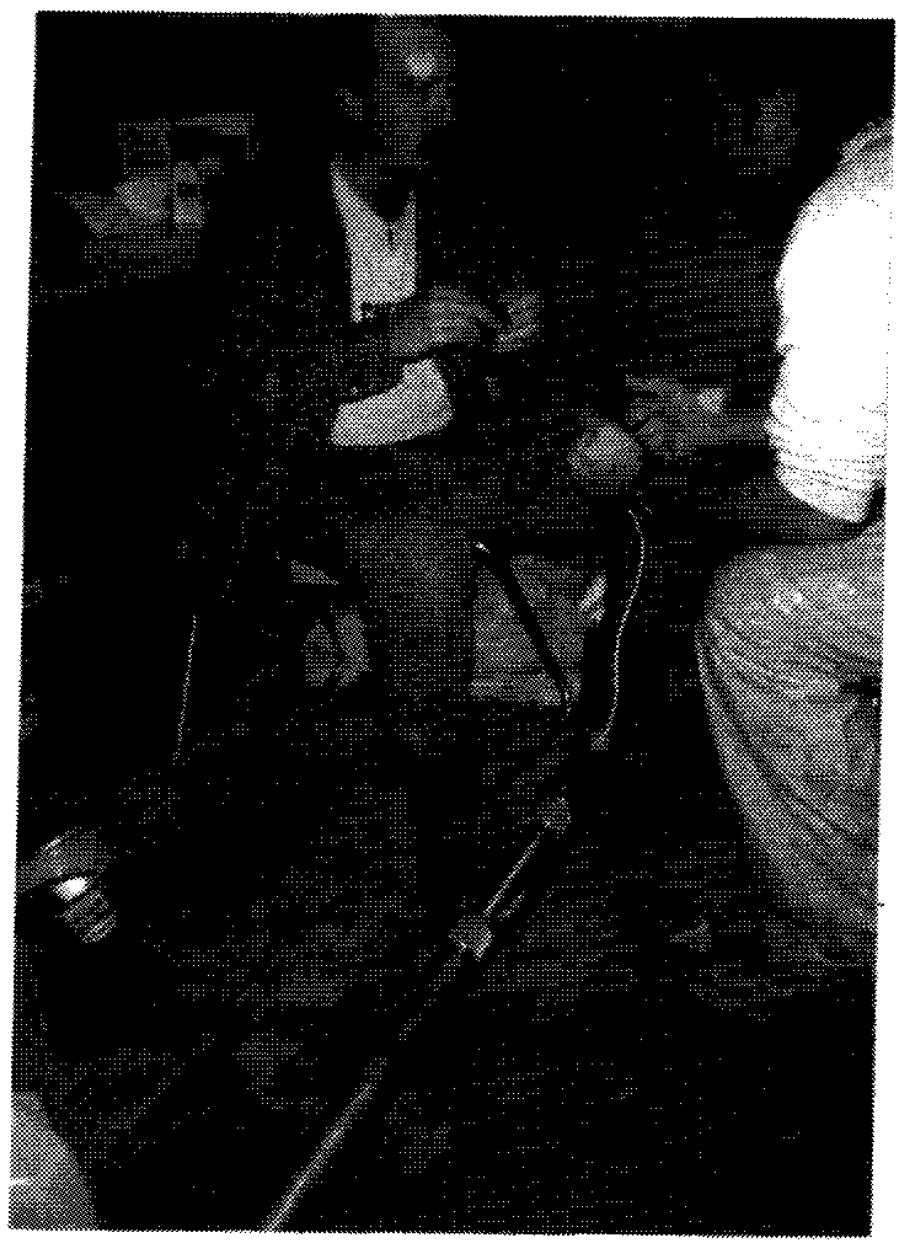

The Magnetic Guidance System (MGS) is shown in the foreground.

The tool is inserted into the Borehole Drilling Assembly.

The wire attached to the top connects the MGS to the computer.

Figure 4-4. Magnetic Guidance System 
Demonstration of River Crossing Technology for Installation of Envirommental Horizomtal Wells: AMH -6 and AMH-7 Installation Report

CDM Federal Programs Corporation

May 5,1993
Westinghouse Savannah River Company Subcontract No. AA46325P

Task Order No. 10

\section{THIS PAGE INTENTIONALLY LEFT BLANK}


Dexwonstution of River Crossing Technology for Installation of

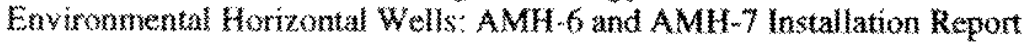

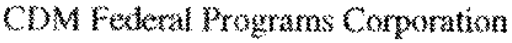
May 5.1993
Westinghouse Savannah River Company Subcontract No. AA46325P Task Order No. 10

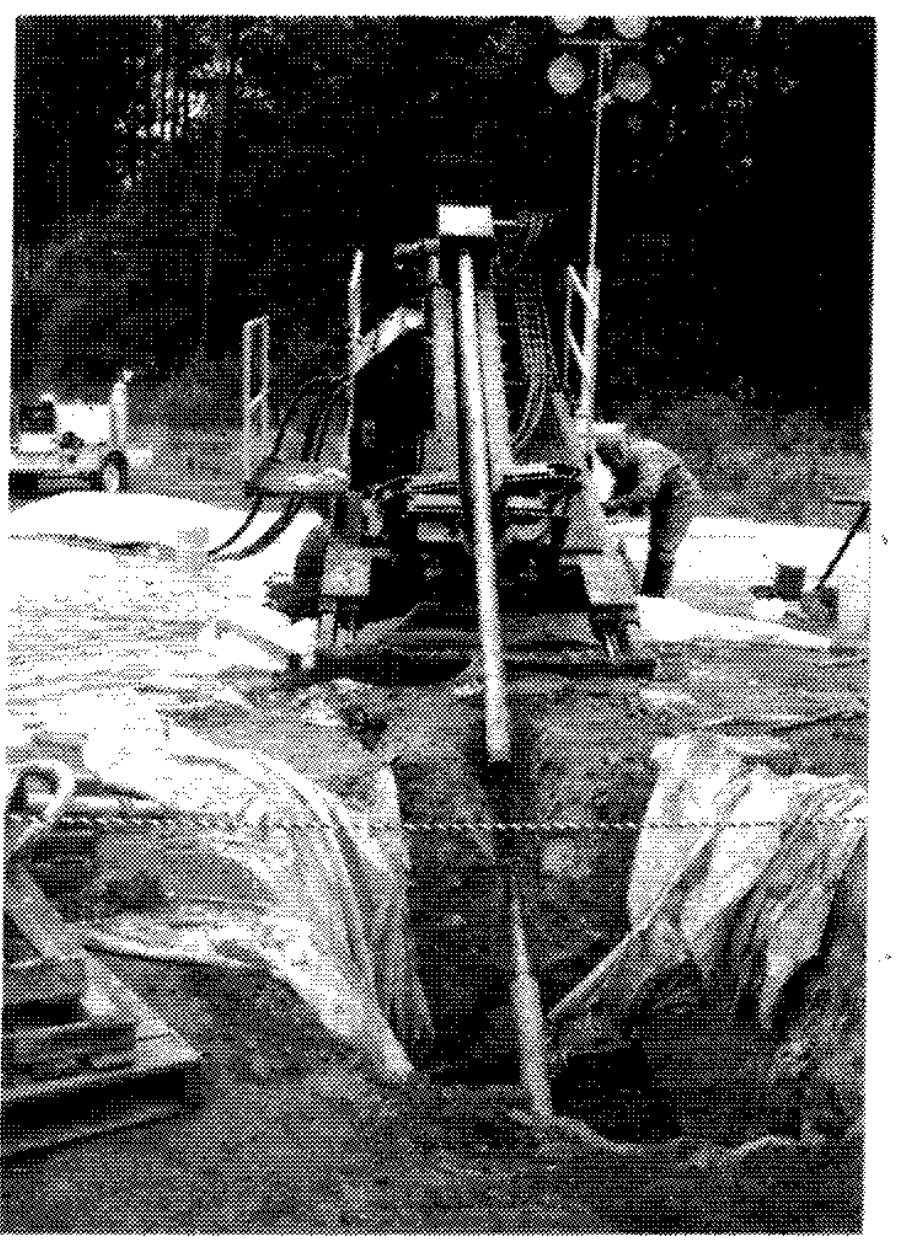

The four-nch washover pipe can be seen protruding at the base of the drill pit and attached to the drilling rig. The wo-inch pilot string can be seen projecting out of the washover pipe.

Figure 4-5. Drill String Assembly 
Demonstration of River Crossing Technology for Installation of

Westinghouse Savannah River Company Environmental Horizontal Wells: AMH-6 and AMH-7 Installation Report COM Federal Programs Corporation Subcontract No. AA46325P

May 5,1993

Task Order No. 10

THIS PAGE INTENTIONALLY LEFT BLANK 
Demonstration of River Crossing Technology for Installation of Enwironmemial Horizontal Wells: AMI 6 and AMH 7 Installation Report CoM Federal Programs Comporation May 5.1093
Westinghouse Sayamnah River Company Subcontract No. AA46325P Task Order No. 10

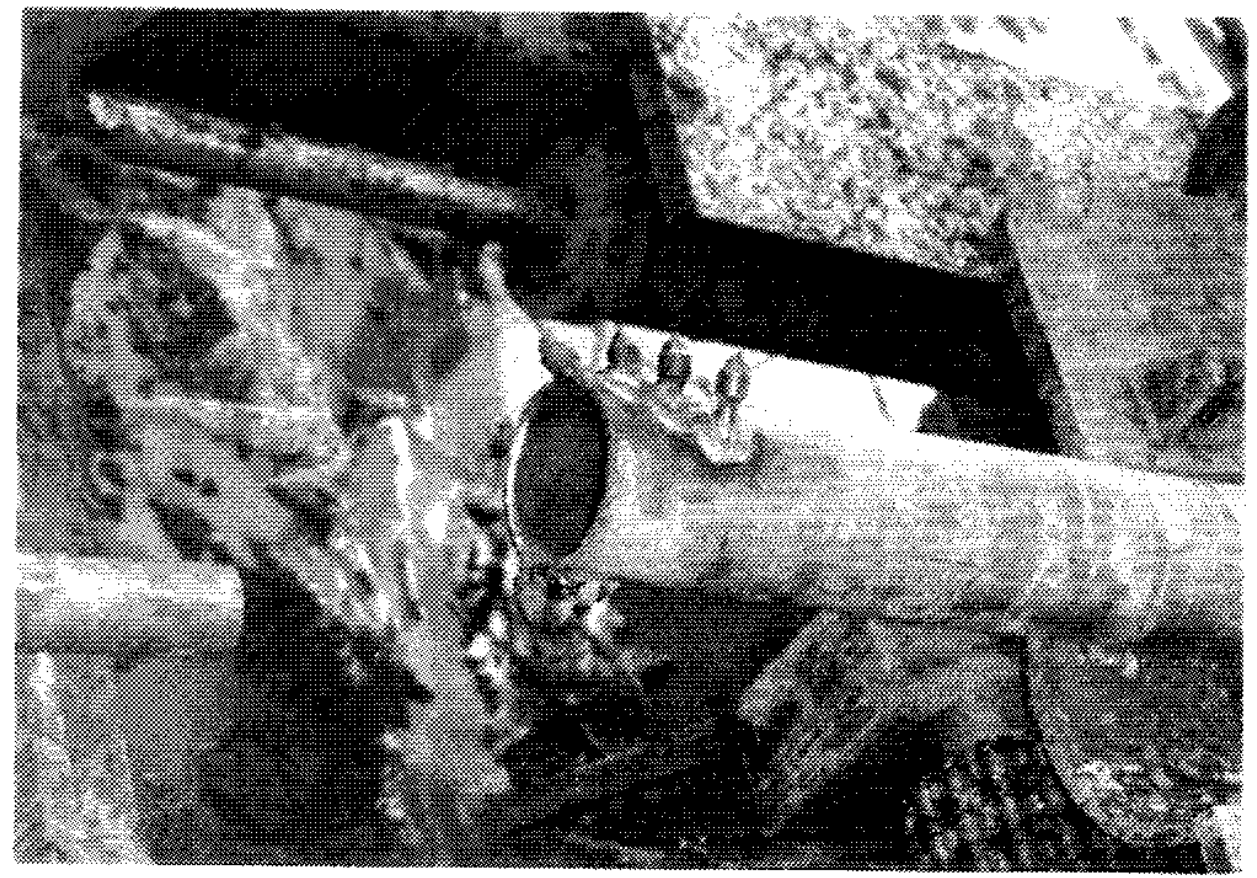

The minemend drill bil consists of carbide tips welded to a four-inch washover coupling.

Digure 4.6. Nine-Inch Drill Bit Attached to Washover Pipe 
Demonstration of River Crossing Technology for lnstallation of Enviromental Horizontal Wells: AMH -6 and AMH-7 Installation Report CDM Federal Programs Corporation

May 5,1993
Westinghouse Savannah River Company Subcontract No. AA46325P

Task Order No. 10

\section{THIS PAGE INTENTIONALLY LEFT BLANK}


Demonstration of 2 verer Crosing Technology for Installation of Enviromwertal Howizontal Wells: AMH 5 and AMH 7 lnstallation Report CDM waderal Programs Corporation May 5,1993
Westinghouse Savamah River Company

Subontract No. AA46325P

Task Order No. 10

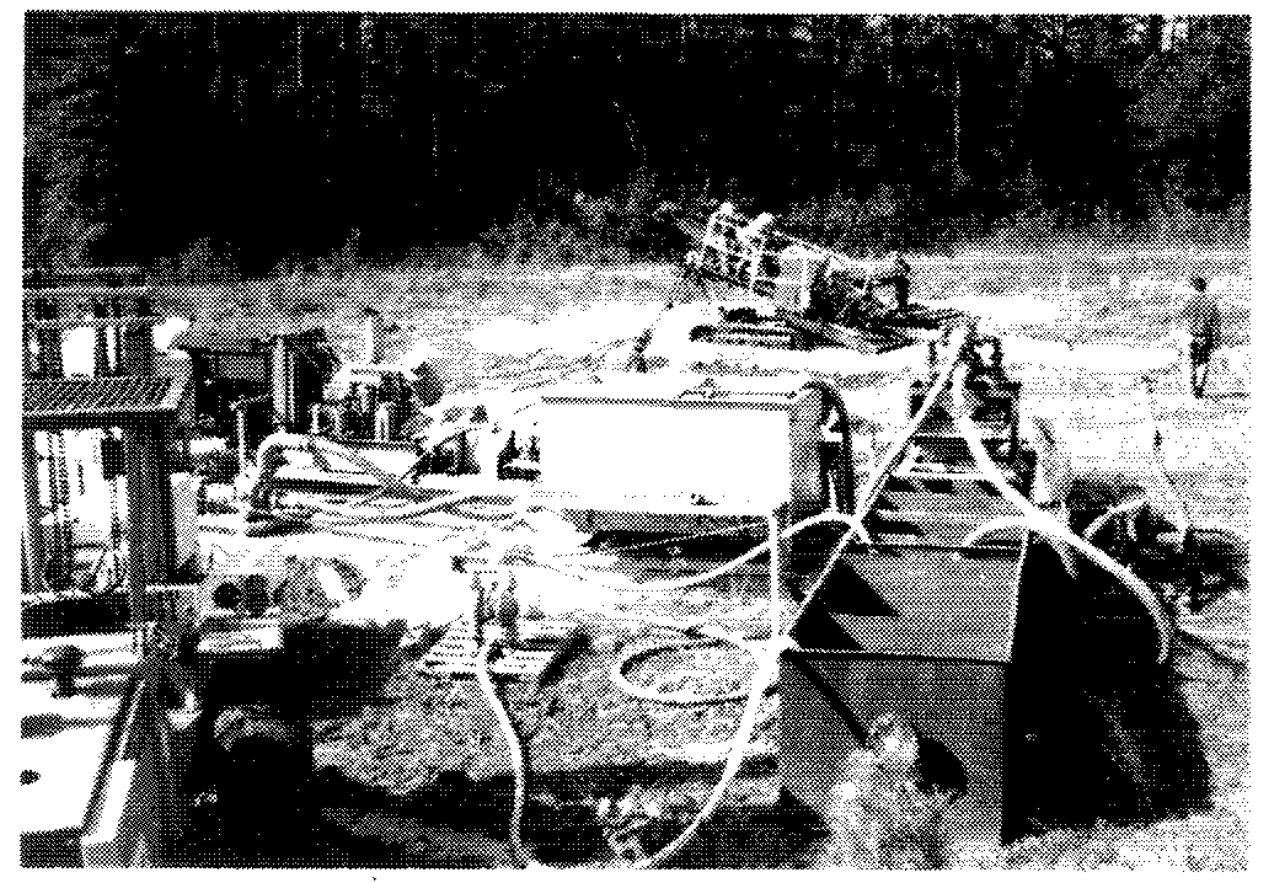

The light green tank in the foreground is the mixing tank. The mud pumping system is to the left of the mud mixing tank. The mud pit is directly in front of the drilling rig in the background. The mud setting tank/desander is the light brown tank in the right foreground.

Tigure 4.7, Mud System Set-Up 
Demonstration of River Crossing Technology for Installation of Westinghouse Savannah River Company Environmental Horizonal Wells: AMH-6 and AMH-7 Installation Report CDM Federal Frograms Corporation Subcontract No. AA46325P May 5.1993 Task Order No. 10

\section{THIS PAGE INTENTIONALLY LEFT BLANK}


Denonstration of liver Crossing Technology for Installation of

Enviromxuental horizontal Wets: AMH -6 and AMH-7 Installation Report

CDM Fedent Fograms Corporation

Mary 5,1993
Westinghouse Savannah River Company

Subcontract No. AA46325P

Task Onder No. 10

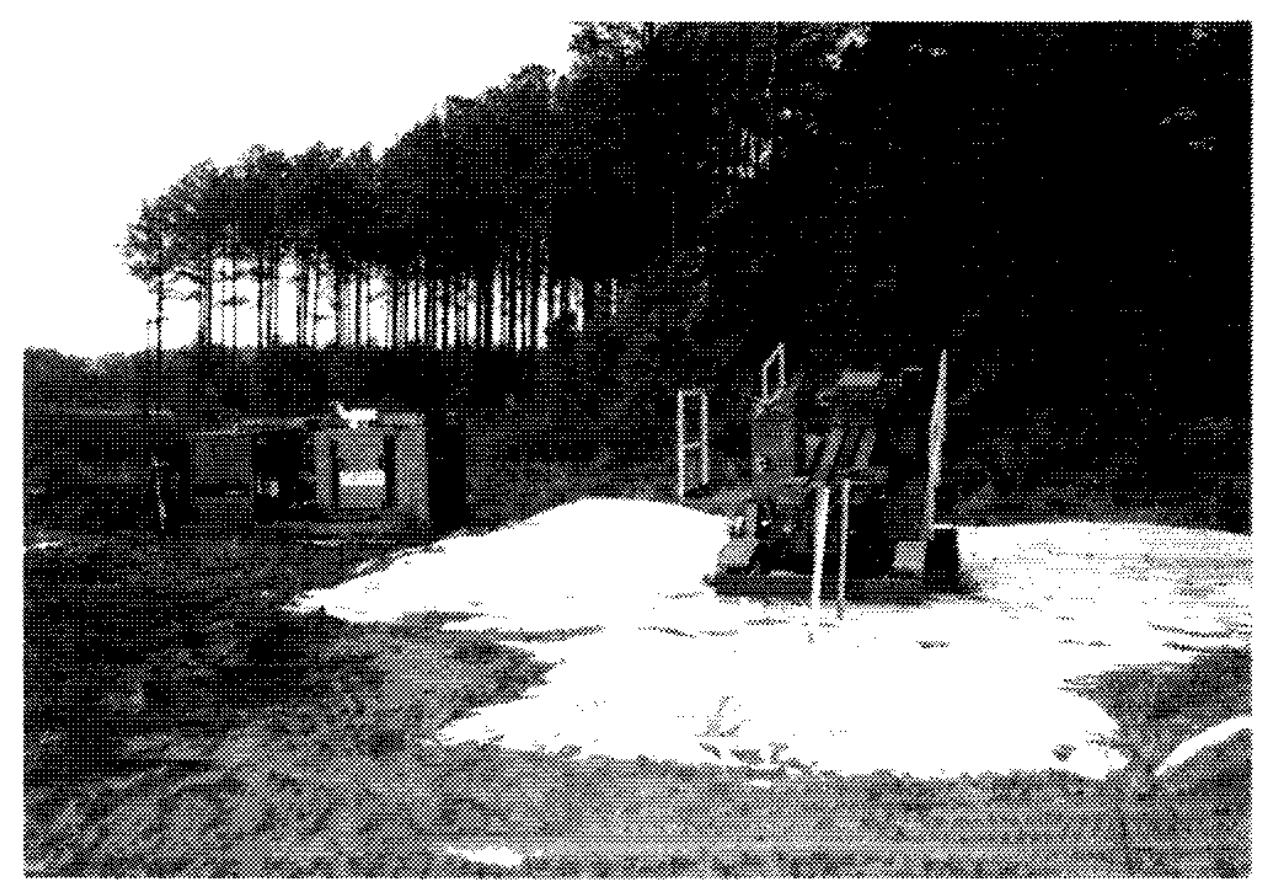

The drill site is lined with 0.010 millimeter-thick plastic sheeting. The plastic extends under the drilling rig and down into the mud pit.

Figure 4-8. Drill Site Set-Up with Lined Drill Pad and Sump 
Dexnonstration of River Crossing Technology for Installation of Exvironmental Horizontal Wells: AMH-6 and AMH-7 Installation Report CDM Federal Programs Corporation

May 5,1993
Westinghouse Savanuab River Company Subcontract No. AA46325P Task Order No. 10

THIS PAGE INTENTIONALLY LEFT BLANK 
Demonstration of River Crossing Technology for Installation of

Westinghouse Savannah River Company

Environmental Horizontal Wells: AMH-6 and AMH-7 Installation Report

Subcontract No. AA46325P

CDM Federal Programs Corporation

Task Order No. 10

May 5,1993

\subsection{TECHNICAL APPROACH}

One of the objectives of the project was to install two identical and parallel horizontal wells beneath the $M$-Area Settling Basin and to demonstrate river crossing directional drilling and horizontal well installation technology. The horizontal wells will be part of a soil gas extraction system designed to remediate the vadose zone beneath the M-Area Settling Basin and prevent further migration of VOCs downward into the groundwater. SRTC decided to install the wells approximately 10 to 15 feet above the water table in a clayey sand horizon at an elevation of 240 - 245 feet above mean sea level (msl). The horizon was chosen because it appeared to be a permeable zone close to the water table. During operation of the soil gas extraction system air will pass from the surface through the vadose zone to the horizontal wells. Aerating the vadose zone in this manner will maximize the removal of the VOCs. The wells were planned to be constructed 100 feet apart (Fig. 5-1) beneath one half of the basin.

Borehole Path - Plan 1

The directional drilling and horizontal well installation plan was devised by the drilling contractor, CEC, and approved by SRTC. The methodology is described in Section 4.0. The directional drilling plan was based on the need to construct a $430-\mathrm{ft}$-long borehole at the target depth below the basin. A diagram used for calculating the borehole path is shown in Figure 5-2; the pertinent borehole path data were:

Target Elevation:

Entry Elevation:

Total Vertical Depth (TVD):

Radius of Curvature:

Approach Angle:

Step-off Distance:

Kick-off Point:

Length of Curve:

End of Curve:

Total Measured Depth:
243 feet msl

353 feet $\mathrm{msl}$

110 feet

300 feet $\left(19^{\circ} / 100\right.$ feet $)$

$25^{\circ}$ from the horizontal

302.7 feet

194.1 feet Measured Depth (MD), 82.0 feet Vertical Depth (VD)

130.9 feet

324.3 feet $\mathrm{MD}$

754.3 feet $M D$

\section{Borehole Path - Plan2}

The first borehole path plan was abandoned after the first attempt to drill a borehole with the above specifications failed. It was believed at the time that the radius of curvature was too short and therefore the radius of curvature was increased to 400 feet. The well separation was decreased to 80 feet. A diagram used for calculating the borehole path is shown in Figure 5-2; the pertinent borehole path data were:

Target Elevation:

Entry Elevation:

Total Vertical Depth:

Radius of Curvature:

Approach Angle:

Step-off Distance:

Kick-off Point:
243 feet msl

353 feet $\mathrm{msl}$

110 feet

400 feet $\left(14.4^{*} / 100\right.$ feet $)$

$25^{\circ}$ from the horizontal

325.9 feet

173.2 feet $\mathrm{MD}, 73.2$ feet VD 
Demonstration of River Crossing Technology for Installation of Envirommental Horizontal Wells: AMH-6 and AMH-7 Installation Report CDM Federal Trograms Corporation

May 5,1993

Length of Curve:

End of Curve:

Total Measured Depth:
Westingthouse Savannah River Company Subcontract No. AA46325P

Task Order No. 10

\section{Horizontal Well installation Plan}

The boreholes were constructed using a dual drill pipe system as described in Section 4.0 . Once the pilot drill string attained the total measured depth and the washover pipe was drilled to the total measured depth, the pilot string was retrieved from the borehole. The well materials were then pushed into the washover pipe until the well screen was placed in the entire horizontal section beneath the basin. The well materials were chosen by SRTC and CEC. The well screen was 0.010 inch slotted three-inch internal diameter schedule 40 polyvinyl chloride (PVC) pipe. The riser casing was solid three-inch internal diameter schedule 40 PVC pipe. 
Demonstration of River Crossing Technology for Installation of

Westinghouse Savannah River Company Environmental Horizontal Wells; AMH -6 and AMH-7 Installation Report CDM Federal Programs Corporation

Subcontract No. AA46325P

May 5,1993

Task Order No, 10

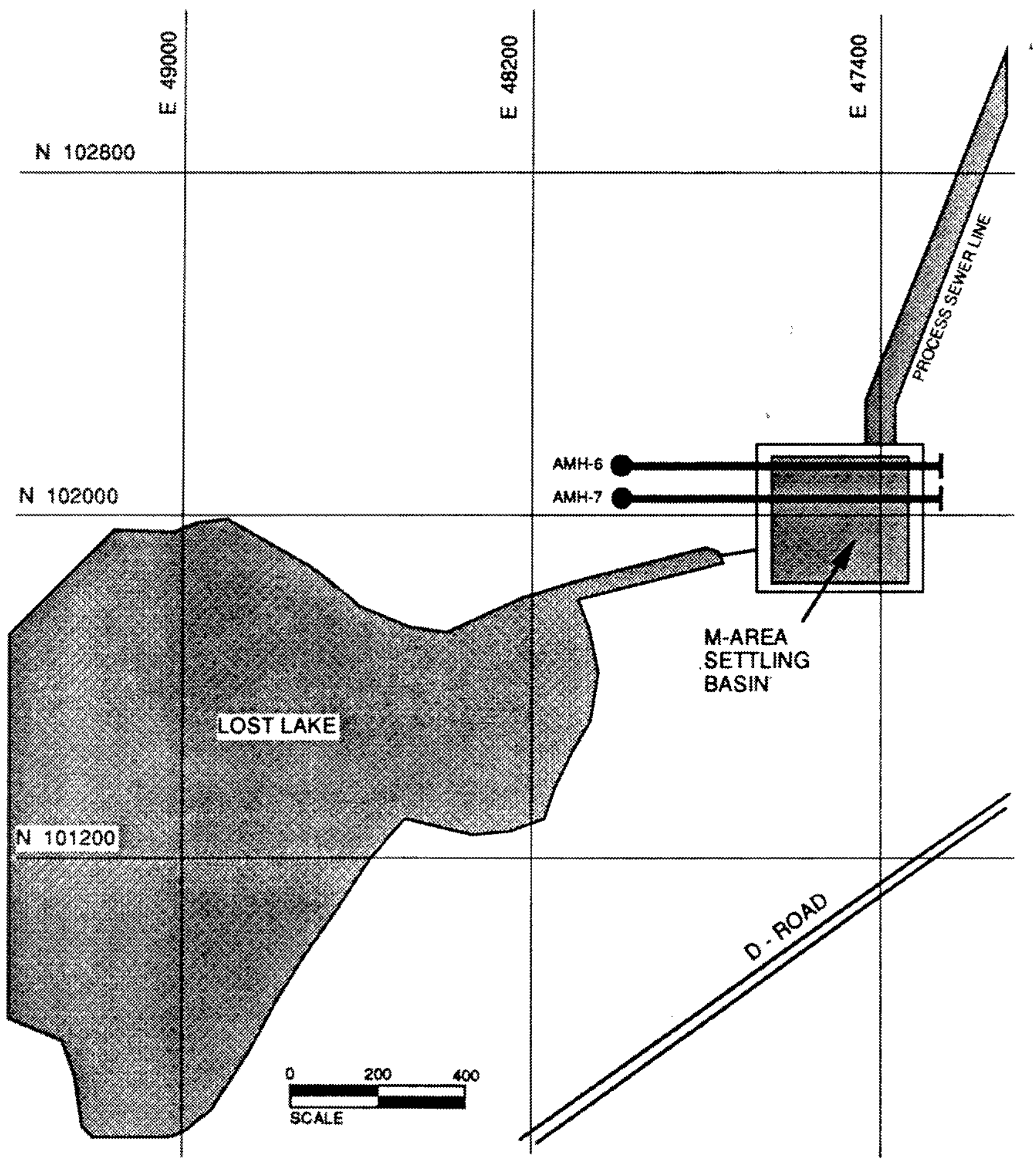

Figure 5.1. Proposed Path (Plan View) of Horizontal Wells in M Area 
Dexonconstration of River Crossing Technology for Installation of

Westinghouse Savannah River Company Eavironmental Horizontal Wells: AMH-6 and AMH-7 Installation Report CDM Federal Programs Corporation

Subcontract No. AA46325P

May $\$, 1993$

Task Order No. 10

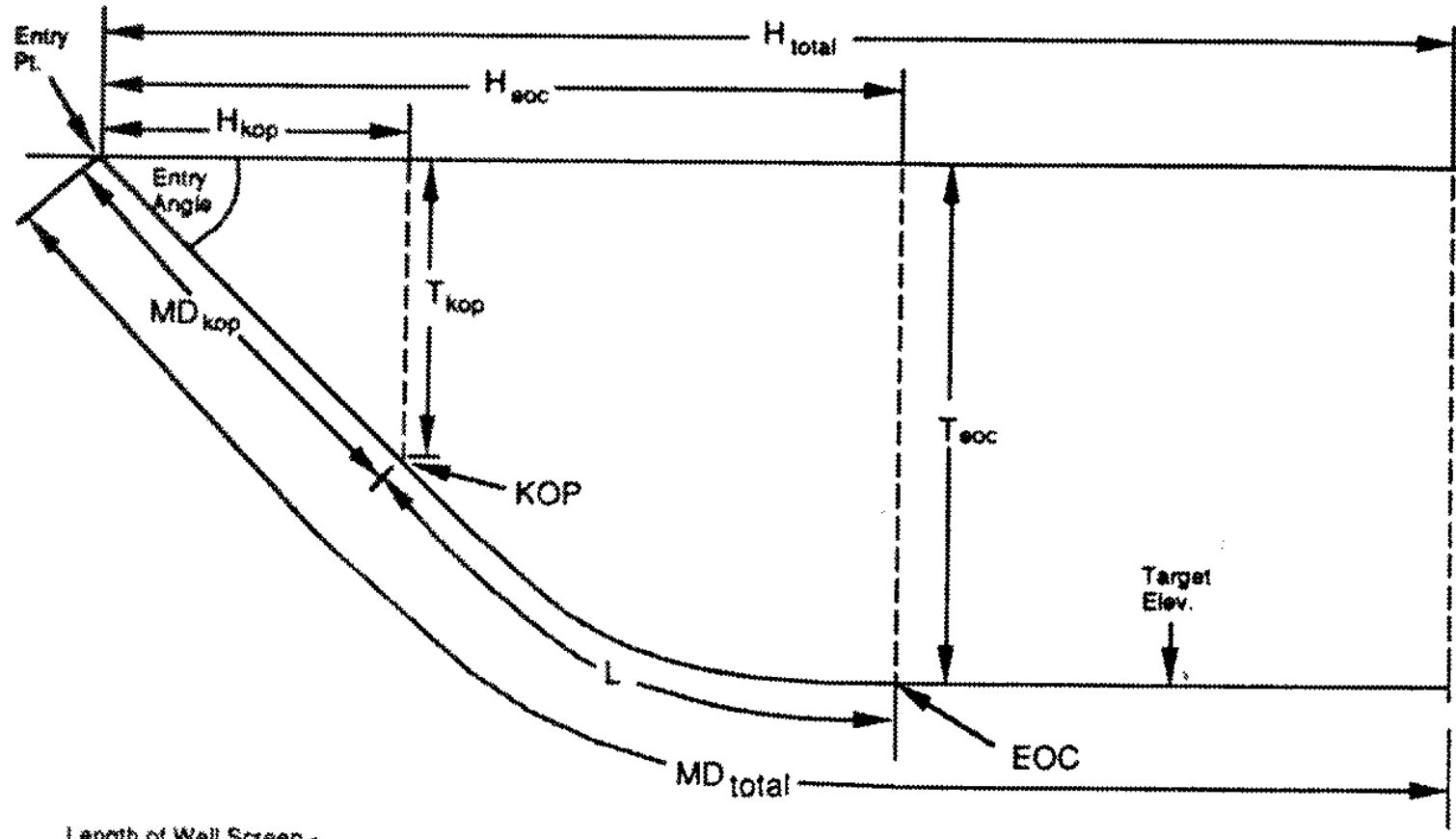

Wals son

Etation atritry.

Etovation of Targent.

Ertry Angio.

Doph to Tarcet

Fadits of Curyation .

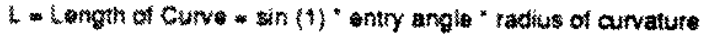

EOC End of Curve

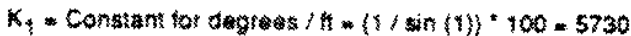

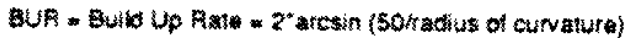

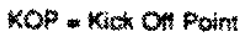

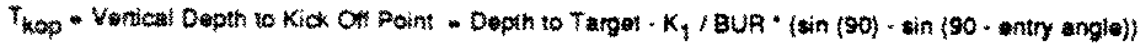

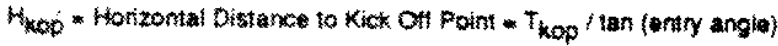

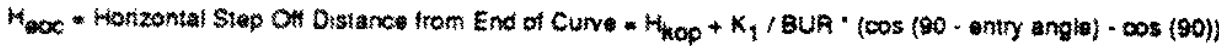

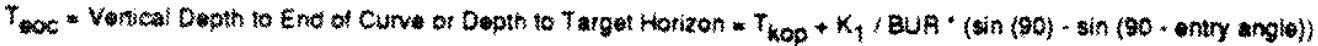

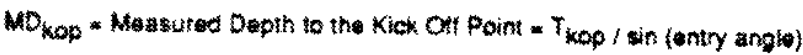

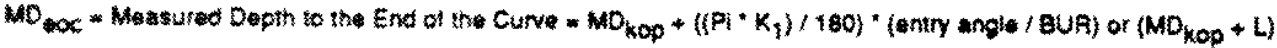

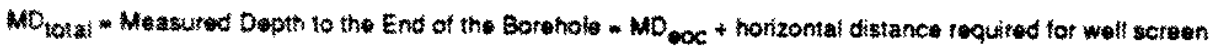

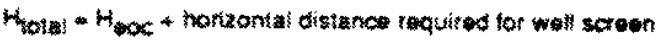

Figure 5-2. Diagram (in Cross Section) of Horizontal Well Layout 
Demonstration of River Crossing Technology for Installation of Environmental Horizontal Wells: AMH-6 and AMH-7 Installation Repor CDM Fexieral Programs Corporation May 5,1993
Westinghouse Savannah River Company Subcontract No. AA46325P Task Order No. 10

\subsection{WELL CONSTRUCTION SUMMARY}

Directional drilling and horizontal well installation activities began on November 11, 1992 and continued until December 25, 1992. This section contains a description of the activities for this period. Appendix A contains a detailed account of drilling and fishing activities. Appendix B contains the Daily Activity Reports for this period. Appendix $C$ contains photographs of the drilling activities for this period. Appendices $D$ and $E$ contain well construction diagrams and as-built diagrams, respectively. Appendix F provides specific information on the Guar Gum drilling additive utilized for this task.

A health and safety orientation meeting was conducted during the morning of November 11 , 1992 by the SRTC representative. The items discussed during the meeting were the health and safety plan, the objectives of the drilling program, and the drilling plans. After the meeting $\mathrm{CEC}$ personnel began preparing the site for drilling operations. Inclimate weather and equipment break-downs forced site preparation activities to continue until the aftemoon of November 13,1992 . Site preparation normally does not take that long to complete.

The SRTC representative calibrated the PID unit at the beginning of drilling and on a daily basis thereafter.

\subsection{AMH-6 Borehole Construction - First Attempt}

\section{Preliminary Work}

Preliminary work included setting up the drilling rig, setting up the mud system, and setting up the downhole drilling assembly. The drilling rig was set up on the AMH-6 location and oriented on the proper azimuth and entry angle. The drilling rig power pack and the mud system were set up between the AMH-6 and AMH-7 drilling locations. A mud pit was excavated at the entrance site of AMH- 6 to accumulate and contain drilling fluids. The downhole drilling assembly was assembled and a line of sight survey of the proposed borehole path was performed. As discussed in Section 5.0, the planned paths of the boreholes passed directly below the basin and between several clusters of monitoring wells. It was imperative that the survey tracking be closely monitored to ensure that the existing monitoring wells were not damaged. Sharewell Inc. personnel calibrated the steering tool along the line of site survey to ensure the accuracy of the borehole.

\section{Drilling the Slant}

AMH-6 borehole construction began during the afternoon of November 13, 1992. The pilot drill stem entered the ground at the prescribed $25^{\circ}$ approach angle. As the downhole drilling assembly was initially being advanced (within ten feet of ground surface), drilling fluid was observed discharging out of the subsurface approximately 25 feet from the drill collar. The pilot drill stem was advanced 40 feet into the ground, and 20 feet of washover pipe were installed. The drilling fluid then stopped discharging to the surface.

At 25 feet VD ( 55 feet to 65 feet $\mathrm{MD}$ ), an extremely hard layer was encountered. This layer was likely the "325-ft clay" of the "Upland unit" as mentioned in Section 3.2.4. 
Demonstration of River Crossing Technology for Installation of Envirommental Horizontal Wells: AMH-6 and AMH-7 Installation Report CDM Federal Programs Corporation

May 5,1993
Westinghouse Savannah River Company Subcontract No. AA46325P

Task Order No. 10

The pilot drill string was advanced to 195 feet MD (initial point for beginning the curve). The washover pipe was then advanced to a depth of 160 feet MD. Mud pressures during this portion of the drilling stayed around $300 \mathrm{psi}$. Mud returns were generally good during this initial portion of the hole with some fluid loss at 140 feet $M D$.

\section{Drilling the Curve}

Once the slant portion of the borehole was complete, the pilot hole of the curved section of the borehole was drilled. The pilot drill stem was drilled with a constant build rate of $19^{\circ}$ per 100 feet of borchole through the curve.

The curve was drilled to 262 feet MD ( 245 feet $\mathrm{msl}$ ) when a hard layer was encountered. This hard layer deflected the drill bit up approximately two feet. Pilot string installation continued, and drilling fluid circulation was lost around 290 feet MD. The drillers decided to pull the pilot stem back to the point of encountering the hard layer and correct the deflection in the radius of curvature. The drillers were concerned that this deflection would make the radius of curvature too small and jeopardize the integrity of both the pilot drill stem and the washover pipe. The drillers were successful in re-entering the hard layer at the correct build rate for the curve. The pilot hole was drilled through the curve and into the horizontal portion of the borehole to 363 feet MD. Drilling fluid circulation was regained at 330 feet but was on the whole sporadic. Losses of drilling fluid to the formation during this period were estimated at 2000 gallons. Because of the difficulty in penetrating the formation at the target horizon, the target elevation for the well was moved down from 245 to 243 feet msl.

Once the pilot string was drilled through the radius of curvature, drilling switched back to washover pipe installation. The washover pipe was advanced to 340 feet $\mathrm{MD}$. Drilling fluid circulation was intermittent while the washover pipe was advanced through the curve. At least another 1000 gallons of drilling fluid was lost to the formation during this period.

\section{Drilling the Horizontal}

The pilot drill stem was advanced to 570 feet $\mathrm{MD}$ where drilling became too difficult to advance any further. From 363-570 feet MD the drilling was intermittently hard and soft, and drilling fluid returns were good. The elevation of the downhole drilling assembly at 570 feet $\mathrm{MD}$ was 239.5 feet msl.

The washover pipe installation resumed at 340 feet $M D$. However, at 350 feet $M D$ the drilling fiuid circulation was lost to the formation. The drillers continued advancing the washover pipe to $\$ 30$ feet $\mathrm{MD}$, until drilling became too difficult to advance the washover pipe. It is estimated that 11,000 gallons of drilling fluid were lost to the formation during the 12 hours it took to drill the washover pipe through the section of the well from 340 to 530 feet MD. The washover pipe could not be advanced past 530 feet $\mathrm{MD}$, and the driller decided to advance the pilot drill stem.

The pilot drill stem was advanced to 700 feet MD. Drilling was intermittently hard and soft. Drilling fluid retums were good. Once again the drillers attempted to advance the washover pipe past 530 feet $M D$ and failed. The decision was made to retract the washover pipe to determine if the pipe had broken. The drillers pulled off only 32 joints of washover pipe 
Demonstration of River Crossing Technology for Installation of Enviromental Horizontal Wells: AMH 6 and AMH-7 Installation Report CDM Federal Programs Comporation May 5,1993
Westinghouse Savannah River Company

Subcontract No. AA46325P

Task Order No. 10

before encountering the end of the drill string. The washover drill string had broken off at the box joint of a washover pipe. Twenty-one pieces $(210$ feet) of washover pipe were left down hole with the top of the broken section at approximately 310 feet $\mathrm{MD}$. On November 15 , 1992 , at 2100 hours, drilling was halted until a recovery (fishing) tool could be flown in to extract the broken pipe.

\section{Drill Pipe Recovery Activities}

The recovery activities lasted from November 17, 1992 to November 21,1992 and were ultimately unsuccessful in recovering all the washover pipe and the borehole. The downhole drilling assembly and pilot drill stem were recovered. Drill pipe recovery activities are presented in Appendix A. During the recovery activities, approximately 19,000 gallons of drilling fluid were lost to the formation.

\section{AMH-6 Drilling Summary - First Attempt}

The salient observations that were made during this attempt were that 31,000 gallons of drilling fluid were lost to the formation and the washover pipe broke. No mitigating actions were taken to prevent drilling fluid loss other than thickening the drilling fluid by mixing the guar gum at a rate that prevented total dissolution of the guar gum in the drilling fluid. The result was clumps of guar gum powder (known as "fish eyes") that float in the drilling fluid. The purpose of the fish eyes was to flow into and plug any cavities in the area of the borehole that were experiencing the fluid loss. CEC personnel determined later in the drilling project that the washover pipe was not the proper grade and strength for this drilling technique. Another observation that was made was that the desander in the drilling fluid system did not perform efficiently. The drilling fluid had a high fine sand and silt content and therefore the carrying capacity of the drilling fluid was greatly reduced.

The washover pipe had broken at the first attempt to advance it past 530 feet MD. However, the driller failed to recognize the situation and continued to drill the pilot hole. The time and effort spent drilling the 130 feet of extra pilot hole was wasted. The abandoned borehole remained open until the drilling project was completed. The borehole was then grouted from total depth to the surface.

\subsection{AMH-7 Borehole Construction}

\section{Preliminary Work}

Preliminary work included setting up the drilling rig, setting up the mud system, and setting up the downhole drilling assembly. The drilling rig was set up on the AMH-7 location and oriented on the proper azimuth and entry angle. Because of the problems encountered in drilling AMH-6, the decision was made to move the collar of AMH-7 back to the south approximately 25 feet to increase the radius of curvature on the hole from 300 feet to 400 feet (see Section 5.0). The new location was surveyed in by Sharewell Inc. personnel and reviewed by the SRTC representative. To assist in anchoring the drilling rig to the ground, the drillers utilized a backhoe to push two 10-foot sections of four-inch diameter drill steel into the ground in front of the drilling rig and welded the steel to the rig frame. This allowed for much 
Demonstration of River Crossing Technology for Installation of Environmental Horizontal Wells: AMH-6 and AMH-7 Installation Report CDM Federal Programs Corporation

May 5,1993
Westinghouse Savannah River Company Subcontract No. AA46325P

Task Order No. 10

greater stability during pushing or pulling on the drill rods. The drilling rig power pack and mud system were already set up between the AMH-6 and AMH-7 drilling locations.

A mud pit was excavated at the entrance site of $\mathrm{AMH}-7$ to accumulate and contain drilling fluids. The downhole drilling assembly was assembled, and a line of sight survey of the proposed borehole path was performed. Sharewell Inc. personnel calibrated the steering tool along the line of site survey to ensure the accuracy of the borehole.

\section{Drilling the Slant}

AMH -7 drilling activities began at 0800 hours on November 21,1992 . Initial drilling of the pilot string progressed smoothly until 110 feet $\mathrm{MD}$. At this point the steering tool control wire broke at the downhole drilling assembly. The crew installed washover pipe down to 100 feet and extracted the pilot drill stem and the downhole drilling assembly. The crew reattached the broken wire, reinstalled the pilot stem down to 110 feet, and resumed drilling.

\section{Drilling the Curve}

The pilot hole was drilled from 110 feet $\mathrm{MD}$, through the curve and into the horizontal section, to 360 feet MD. The build rate in the curve was $14.4^{\circ}$ per 100 feet drill stem. A soft horizon was encountered at approximately 239 feet msl. The elevation of the end of the curve was 237.5 feet msl. The washover pipe was then advanced to 300 feet MD. Approximately 3000 gallons of drilling fluid were lost to the formation up to this point in drilling AMH-7.

\section{Drilling the Horizontal}

The drilling conditions at 370 feet MD $(237.5 \mathrm{msl})$ indicated a very dense clay horizon. Drilling fluid pressure was increased to 750 psi, and the pilot string advanced slowly to 400 feet MD. Drilling efforts then switched back to washover pipe installation to ensure that the two-inch pilot string was not getting bound up by drill cuttings. The extreme push pressure on the washover pipe caused the drilling rig to separate from the four-inch steel support pilings. The anchors were reattached. Mud returns to this point were good, and fluid losses to the formation were minimal. The decision was made to drill up two feet to reach the soft horizon encountered at 239 feet $\mathrm{msl}$. The driller did drill upwards, but the drilling did not become easier.

A very hard zone was encountered between 580 and 590 feet MD. This zone deflected the downhole drilling assembly up $2.4^{\circ}$ in a ten-foot length. The borehole deviation was too great to accommodate the washover pipe; therefore, the pilot stem was retracted to approximately 560 feet MD, and the washover pipe was advanced. The cutting ability of the rotary bit on the washover pipe opened up the borehole at the point of deflection, and the downhole drilling assembly returned to the proper trajectory.

Drilling continued, alternating approximately every 50 feet between the pilot string and the washover pipe installation. The drilling was extremely difficult, and cuttings coming back up the annulus indicated that the formation being penetrated was a tan green clay with very little to no sand. At 740 feet MD drilling reached the point of rejection. The decision was made to pull the pilot string back to approximately 710 feet $\mathrm{MD}$ and drill the washover pipe to the total depth 
Demonstration of River Crossing Technology for Installation of Exyironmental Horizontal Wels: AMH 6 and AMH-7 Installation Report CDM Federal Programs Corporation

May 5.1993
Westinghouse Savannah River Company Subcontract No. AA46325P

Task Order No. 10

of the well (770 feet MD). The washover pipe was then retracted forty feet and the pilot string advanced to the end of the well to collect survey information. The drillers completed surveying the well and retracted the pilot drill stem and prepared for installation of the well materials inside the washover pipe.

\section{AMH 7 Drilling Summary}

During the borehole construction, 9,000 gallons of drilling fluid were lost to the formation. No mitigating actions were taken to prevent drilling fluid loss other than thickening the drilling fluid by mixing the guar gum at a rate that prevented total dissolution of the guar gum in the drilling fluid.

\subsection{AMH-7 Well Installation}

The well materials for AMH-7 consisted of:

- One six-inch long, 3-inch diameter, schedule 40 PVC cap.

- 21 pieces of 20 -ft long, flush threaded, 3-inch nominal inside diameter (ID), 0.010-inch slotted schedule 40 PVC screen in the horizontal section below the basin.

- 16 pieces of 20 -foot long and 2 pieces of 10 -foot long, flush threaded, 3 -inch nominal ID, schedule 40 PVC riser above the screen.

The slotted screen was easily installed by hand to 250 feet MD. However, at this depth the buoyancy of the screen within the drilling fluid in the borehole created a frictional force that exceeded the driller's ability to push the screen by hand. Drilling mud was pumped inside the screen to decrease the buoyancy. Once filled with mud, the screen and casing were easily pushed by hand down to approximately 600 feet MD. Sand, built up in front of the screen, made it necessary to use the drilling rig to advance the well casing to the end of the borehole. A cap was placed over the end of the well casing, and the rig drill head pushed slowly on the pipe until the section was near ground level. Once the section of well pipe was installed the cap was removed, another section of pipe added, and the process was repeated. The total installed depth of well AMH-7 was 760.5 feet (750.5 feet below ground surface and 10 feet of casing above the ground surface).

Once the well materials were installed, the washover pipe was extracted. The well installation was completed on November 25,1992 at 1400 hours. The well would be grouted and developed upon completion of drilling and installation of AMH -6 . Drilling and well installation for AMH 7 took just over four days.

\subsection{AMH-6 Borehole Construction - Second Attempt}

\section{Breliminary Work}

Preliminary work included setting up the drilling rig, setting up the mud system, and setting up the downhole drilling assembly. Because of the problems encountered in drilling the first attempt at AMH-6, the decision was made to move the entry site of AMH-6 back to plant west approximately 25 feet to increase the radius of curvature on the hole from 300 feet to 400 feet (see Section 5.0) and to plant south approximately 20 feet, to prevent physical and magnetic 
Demonstration of River Crossing Technology for Installation of Environmental Horizontal Wells: AMH 6 and AMH-7 Installation Report CDM Federal Programs Corporation

May 5,1993
Westinghouse Savamnah River Company

Subcontract No. AA $46325 \mathrm{P}$

Task Order No. 10

interference from the broken section of washover pipe left in the first abandoned attempt on AMH -6 . The new location was surveyed in by Sharewell Inc. and reviewed by the SRTC representative. The drilling rig was set up on the AMH-6 location and oriented on the proper azimuth and entry angle. A drilling fluid return pit was constructed at the entry point, and two 10-foot sections of four-inch diameter drill steel were pushed into the ground in front of the drilling rig and welded to the rig frame to anchor the drilling rig. The drilling rig power pack and the mud system were already set up between the AMH-6 and AMH-7 drilling locations.

\section{Drilling the Slant}

Drilling began on AMH-6 on November 25, 1992 at 2100 hours. Initial drilling of the pilot string progressed to 161 feet $\mathrm{MD}$ before switching over to install the initial sections of washover pipe. The steering tool experienced magnetic interference near the surface that resulted in an azimuth error and a subsequent borehole deviation of 2.3 feet to the right of the proposed borehole path. A standard practice is to "plug" the proposed azimuth into the steering tool software where there is a possibility of magnetic interferences (such as near the ground surface). The Sharewell Inc. survey operator did not plug the proper azimuth. The difference in azimuth was not crucial to the completion of the well. Drilling continued, and the borehole was brought back on the correct path (see Figure 3-9).

Washover installation continued to 140 feet MD (approximately 290 feet msl). Based on the previous attempt at installing AMH-6, SRTC and CEC made the decision to move the target elevation of the well to 245 feet msl. The crew switched to installing the pilot string and began building the angle at 161 feet $\mathrm{MD}$.

\section{Drilling the Curve}

Installation of the pilot string continued to 301 feet MD (approximately 250 feet msl). Washover pipe was installed to 260 feet $\mathrm{MD}$, and then the pilot string was drilled through the curve. At 351 feet MD the end of the curve was reached, and drilling became very difficult. A visual analysis of the cuttings indicated that the bit was penetrating a clayey zone.

\section{Drilling the Horizontal - Stage 1}

Drilling of the pilot hole proceeded smoothly to 511 feet $\mathrm{MD}$ (244 feet msl). The borehole was within a couple of feet of the projected elevation. The steering tool appeared to have experienced no magnetic interference from the broken section of washover pipe that remained in the abandoned borehole left from the first attempt at drilling AMH-6. The drilling, within the horizontal section below the basin, alternated between hard and soft indicating a possible variable clay content in the horizon. To this point, returns for all drilling in this borehole were good, and there appeared to be minimal losses in drilling fluids to the formation. At 511 feet $\mathrm{MD}$, drilling became difficult, and the crew switched to installing the washover pipe. Washover pipe installation began at 250 feet $\mathrm{MD}$ and proceeded to 340 feet $\mathrm{MD}$ where drilling reached the point of rejection. The decision was made to retract the washover pipe to inspect the drill bit for wear. The crew moved the pilot string to ensure it was not stuck in the hole and then proceeded to pull the washover pipe. 
Demonstration of River Crossing Technology for Installation of Environmental Horizontal Wells: AMH-6 and AMH - 7 Installation Report CDM Federal Programs Corporation May 5,1993
Westinghouse Savannah River Company Subcontract No. AA46325P Task Order No. 10

The washover pipe was found to have broken at 270 feet MD; 60 feet of washover pipe remained between 270 and 330 feet $\mathrm{MD}$. The break occurred between the \#6 and \#7 washover pipe above the downhole drilling assembly. The box of joint \#6 was still attached to the pin of joint 7. This relationship of the box breaking off on the pin of the previous pipe is the same for each of the washover pipe failures for this project.

\section{Recovery Activities}

The drillers retracted the pilot drill stem and recovered the downhole drilling assembly. A detailed account of the recovery activities may be found in Appendix $A$. The washover pipe was recovered with a simple hook attached to the pilot drill stem.

\section{Drilling the Horizontal - Stage 2}

The pilot stem with the downhole drilling assembly was re-installed to 511 feet $\mathrm{MD}$, and the washover pipe was re-installed to 330 feet MD. Drilling began again on the washover pipe and proceeded to 405 feet $M D$ where the point of rejection was reached. It appeared that the washover pipe had again broken at some point in the curve.

The drillers retracted the pilot drill stem and recovered the downhole drilling assembly. The pilot drill stem was replaced with a "dummy string" to 511 feet $\mathrm{MD}$. The dummy string consisted of the pilot drill stem without the down-hole drilling assembly. The washover pipe was retracted. The break occurred at 325 feet $\mathrm{MD}$, between washover joints $\# 8$ and $\$ 9$ above the drill bit. The box of joint \#8 was still attached to the pin of joint \#9. Eighty feet of washover pipe was left in the hole between 325 and 405 feet MD.

\section{Recovery Activities}

A detailed account of the recovery activities may be found in Appendix A. The washover pipe was recovered with a simple hook attached to the pilot drill stem. The total down time for retrieving the broken washover pipe was 24 hours.

\section{Drilling the Horizontal - Stage 3}

The pilot drill stem with the down-hole drilling assembly was re-installed in the borehole to $\$ 11$ feet $\mathrm{MD}$, and the washover pipe was re-installed to 405 feet MD. Because there was a major concern that the washover pipe had been weakened by the cumulative stresses of the previous drilling activities, the drillers decided to use lower rotational speed and push force to put less strain on the joints of washover pipe as they rotated through the curved section of the borehole. CEC and the SRTC representative agreed that the rotational speed would not exceed 30 rpms.

Drilling of the washover pipe resumed and mud losses to the formation became significant. The crew completed pushing the washover pipe to 490 feet MD; however, fluid losses to the formation had reached 1000 gallons per twenty feet of borehole drilled.

The pilot drill stem was drilled 611 feet $\mathrm{MD}$. At this point the drillers took a 30 -minute break for dinner. Upon returning from dinner break, all of the drilling mud had drained out of the 
Demonstration of River Crossing Technology for Installation of Euvironmental Horizontal Wells: AMH -6 and AMH-7 Installation Report CDM Federal Programs Corporation

May 5,1993
Westinghouse Savannah River Company Subcontract No. AA46325P Task Order No. 10

mud pit and presumably into the formation. The borehole took an entire tank of drilling mud just to regain circulation. Mud losses to the formation appeared to have begun while drilling the washover pipe between 420 to 440 feet MD. Circulation could be maintained as long as mud was being pumped down the borehole. However, if the drilling stopped, the thick mud would visibly flow back down the hole and into the formation by the hydrostatic head pressure of the drilling mud alone. Analysis of the potential causes for these fluid losses will be discussed in Section 7.0 .

Pilot string installation continued to 631 feet $\mathrm{MD}$. While drilling 620 to 630 feet $\mathrm{MD}$, the directional drilling tube was pointed up but the inclination of the borehole (as indicated on the survey tool) dropped down $4^{2}$. This indicated that the downhole drilling assembly encountered very soft material or an open void. Approximately 1000 gallons of drilling fluid were used to drill this ten feet of borehole. The amount of drilling fluid running out of the mud pit and into the formation under hydrostatic pressure alone was estimated by observing that the fluid level in the $10 \mathrm{ft} . \times 6 \mathrm{ft}$. mud pit was dropping 1 inch per minute. The estimated rate of fluid loss was 5 cubic feet or 40 gallons per minute.

The drilling crew decided to advance the washover pipe to the end of the pilot drill stem to mitigate the drilling fluid loss. However, the washover pipe would not advance further. The crew then pulled on the washover pipe until it jerked suddenly. The jerk indicated that the washover pipe had broken downhole. The washover pipe was extracted. The break in the washover pipe occurred at 80 feet $\mathrm{MD}$, between washover joints $\# 42$ and $\# 41$ above the drill bit. The box of joint $\# 4$ still attached to the pin of joint $\# 42$. The 400 feet of washover pipe remaining in the borehole was between 80 and 480 feet $M D$.

\section{Recovery Activities}

The recovery activities are described in Appendix A. The washover pipe was not recovered from the horizontal section of the borehole.

\section{Drilling the Horizontal - Stage 4}

CEC proposed to SRTC that they would drill 270 feet past the end of the broken section of washover pipe and install the well materials in an open borehole. The result would be 270 feet of open screen beneath the M-Area Settling Basin. SRTC decided to accept the well if CEC could install 250 to 280 feet effective screen below the basin. The SRTC decision was made because of their concem of the massive fluid losses to the formation. A replacement well would be drilled only if all other attempts at salvaging the current borehole failed.

The pilot drill stem was advanced to 745 feet MD. The pilot borehole was sized to a larger diameter to facilitate the installation of the well materials. The open borehole was between 480 feet MD to 745 feet $\mathrm{MD}$.

\section{AMH -6 Drilling Summary - Second Attempt}

Approximately 34,000 gallons of drilling fluid were lost to the formation during this attempt, the washover pipe broke numerous times, and the well was not completed to the original specifications. No mitigating actions were taken to prevent drilling fluid loss other than 
Demonstration of River Crossing Technology for Installation of Environmental Horizontal Wells: AMH-6 and AMH-7 Installation Report

Westinghouse Savannah River Company CDM Feateral Programs Corporation

Subcontract No. AA46325P

May 5,1993

Task Order No. 10

thickening the drilling fluid by mixing the guar gum at a rate that prevents total dissolution of the guar gum in the drilling fluid. CEC personnel determined that the washover pipe was not the proper grade and strength for this drilling technique. The desander in the drilling fluid system did not perform efficiently. The drilling fluid had a high fine sand and silt content and therefore the carrying capaciry of the drilling fluid was greatly reduced. Many days were spent trying to extract washover pipe that was stuck in the borehole. The end result was that the washover pipe remained in the borehole and that the well screen was not the originally proposed length.

\subsection{AMH-6 Well Installation}

The well construction materials for AMH-6 consisted of:

- One six-inch long, 3-inch diameter, schedule 40 PVC cap.

* Twenty pieces of 20 -ft long, flush threaded, 3 -inch nominal $\mathrm{ID}, 0.010$-inch slotted schedule 40 PVC screen in the horizontal section below the basin.

- Eight pieces of 20 -foot long and 16 pieces of 10 -foot long, flush threaded, 3 -inch nominal $\mathrm{ID}$, schedule 40 PVC riser above the screen.

The slotted screen was easily installed by hand to a MD depth of 295 feet; however, at this depth the buoyancy of the screen within the drilling mud exceeded the driller's ability to push the screen by hand. A cap was attached to the top of the well pipe, but the drilling rig was unable to push the well materials downhole without the possibility of breaking the PVC pipe. The crew thinned out the drilling mud to allow easier penetration by the well material, but this did not work. The two-inch pilot drill stem was installed inside the well material to push the well material from the bottom of the screen. This technique proved successful, and the well was advanced to 710 feet MD.

At 710 feet $\mathrm{MD}$, the well material would not advance any further. The drillers felt they had pushed the cap off of the end of the screen. Well installation could proceed no further. The result was that there was a total of 230 feet of well screen open to the formation. SRTC personnel decided to accept the well length although the length was 20 feet less than the minimum length agreed upon earlier. SRTC personnel wanted to prevent further damage to the target horizon.

A plug, designated as a "one way pig", was installed to within five feet of the end of the screen to reseal the end of the well. The plug consisted of a 6 "long, 3.25 " diameter polypropylene plug. The total installed depth of well AMH-6 was 720 feet ( 710 feet below ground surface and 10 feet above ground). The total effective screen installed beyond the broken section of washover pipe in AMH 6 is 225 feet (710 feet MD minus 480 feet for the broken washover pipe and 5 feet for the plug).

The drillers attempted to remove the extra washover pipe that had been installed from the surface down to the top of the broken section; however, the pipe would not move. Sand had apparently settled in around the splayed end of the washover pipe, preventing it from being extracted. Instead of risking damage to the installed well, the drillers rotated the washover pipe counterclockwise to unscrew as much of the pipe as possible. Only 6 sections of washover 
Demonstration of River Crossing Technology for Installation of Environmental Horizontal Wells: AMH-6 and AMH-7 Installation Report CDM Federal Programs Corporation May 5, 1993
Westinghouse Savannah River Company

Subcontract No. AA46325P

Task Order No. 10

pipe were extracted, leaving 420 feet of washover casing down the hole from 60 to 480 feet MD.

\subsection{AMH-6 and AMH-7 Well Completion}

Well completion was accomplished by: installing sand by tremmie pipe in the annulus above the well screen; installing a bentonite plug in the annulus above the sand; and filling the annulus with grout from the bentonite plug to the surface (see Appendix D for Horizontal Well Construction Diagrams). Both wells were completed on December 9, 1992. The total time for installation of the two horizontal wells was 26 days.

\subsection{AMH-6 and AMH-7 Well Development}

The well materials were installed using hydraulic pressure supplied by the drilling fluid system. The drilling fluid used during the installation of AMH-7 had a significant silt and fine sand fraction. Therefore, AMH-7 had a significant amount of sand in the well screen after well installation was complete. The drilling fluid used to install AMH-6 did not have a significant silt and sand fraction and therefore AMH-6 did not contain a significant amount of sand in the well screen.

\section{AMH-6 Well Development}

Development of AMH-6 began on December 12, 1992. The crew installed 330 feet of two-inch PVC tremmie pipe with a perforated six-inch pointed plug on the end (Fig. 6-1) into the well. The perforations consisted of approximately eight $1 / 4$ " angled holes. The purpose of the holes was to force water and air back uphole to wash sediment from the screen.

When the tremmie pipe reached 330 feet $\mathrm{MD}$, water was injected as each 10 -foot section of pipe was added. The tremmie pipe was push to 635 feet $\mathrm{MD}$, at which time the crew could no longer advance the pipe. Approximately 2500 gallons of fresh water was pumped down the well during the four hours of tremmie pipe installation between 330 feet and 635 feet MD; however, no returns came to the surface (with all the drilling fluid lost, no returns were expected).

Apparently the water (and whatever sand) in the well was blowing back uphole but the pump was not strong enough to force the sand and water to the surface. The tremmie pipe was extracted from AMH -6, several more holes drilled in the plug, and the pipe reinserted into the well. The plan was to: insert the tremmie pipe into the well until the first sand was encountered; pump water; and then air lift to see if any fluids and/or cuttings returned to the surface. The tremmie pipe was installed to 360 feet before the first sand was encountered. Approximately 200 gallons of water were pumped down the hole before the crew began blowing air down the tremmie pipe. No returns were observed at the surface.

The driller decided to advance the tremmie pipe to the end of the well and blow with air as the pipe was being extracted, forcing the sand out laterally into the walls of the borehole. Tremmie pipe was installed to 705 feet $\mathrm{MD}$, and the air development technique was applied. The technique was successful, and the well screen was cleared of sediments. 
Demonstration of River Crossing Technology for Installation of Envizonmental Horizontal Wells: AMH-6 and AMH 7 Installation Report CDM Federal Programs Corporation May 5.1993
Westinghouse Savannah River Company Subcontract No. AA46325P

Task Order No. 10

\section{AMH.7 Well Development}

AMH.7 well development proceeded with the same techniques used to develop AMH-6. Development of AMH-7 began on December 14, 1992. The crew installed 735 feet of twoinch PVC tremmie pipe with the perforated plug on the end into the well. The tremmie pipe was installed easily by hand to 610 feet before water was needed to assist in advancing the pipe. At 735 feet, the sand remaining in the screen zone had either been forced out into the formation or compressed into the last 15 feet of the screen zone, making the effective screen length of AMH-7 405 feet. Several hundred gallons of water were pumped down the well over a three-hour period with no returns at the surface. The crew began continuously injecting air into the well while extracting the tremmie pipe, forcing the sand and silt laterally out of the screen into the formation. This technique was applied until all tremmie pipe was extracted from the well. Development on AMH-7 was completed on December 15, 1992. 
Demonstration of River Crossing Technology for Installation of Einvironmental Horizontal Wells: AMH-6 and AMH-7 Installation Report CDM Federal Programs Corporation

May 5,1993
Westinghouse Savamah River Company Subcontract No. AA46325P

Task Order No. 10

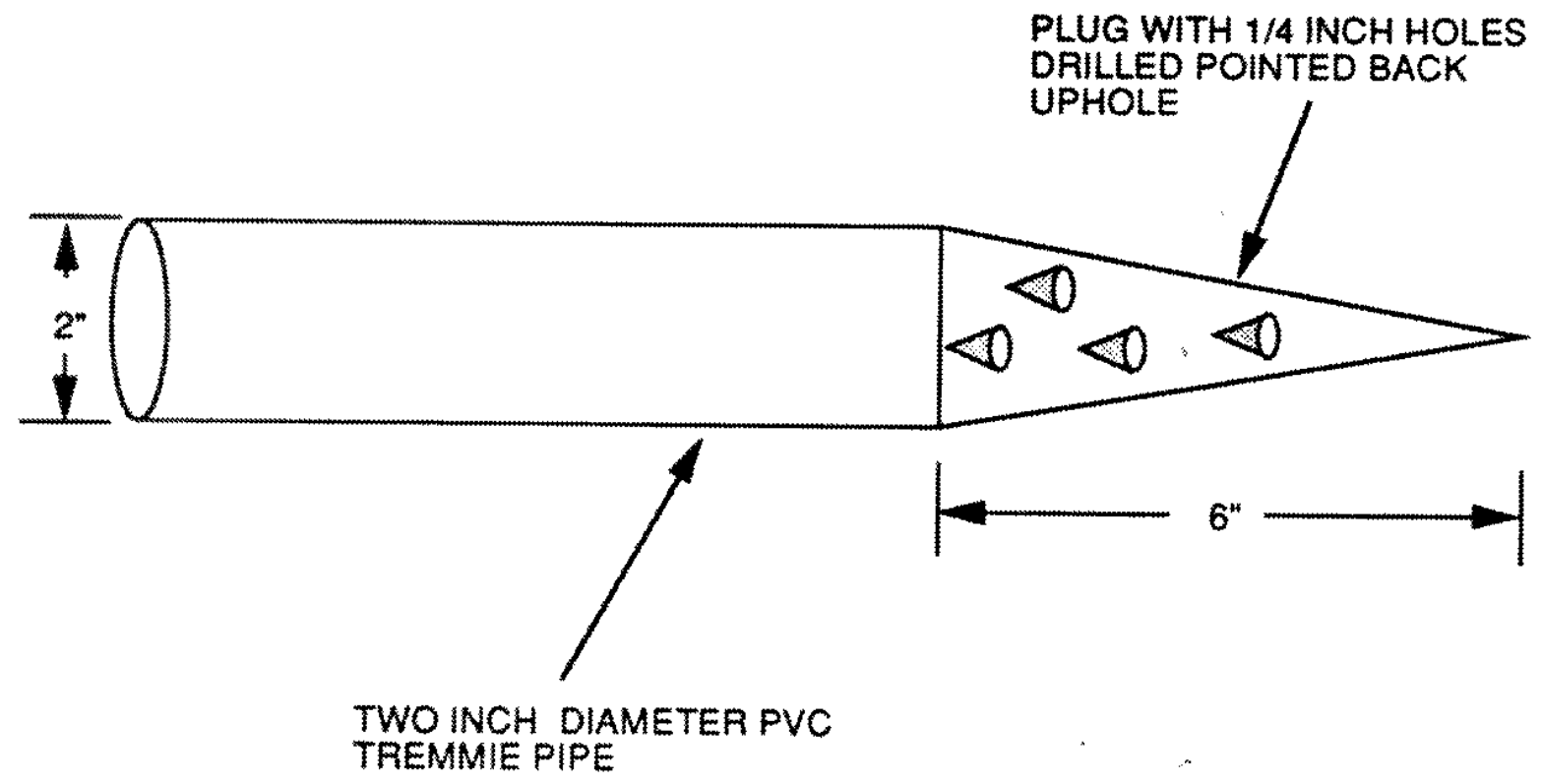

A six-inch long, two-inch diameter plug was perforated with $1 / 4^{\prime \prime}$ holes for blowing water and/or air down inside the three-inch well for cleaning sand and mud out during well development.

Figure 6-1. Two-Inch Diameter Perforated PVC Plug for Well Development 
Demonstration of Rivet Crossing Technology for Installation of Environmental Horizontal Wells: AMH-6 and AMH -7 Installation Report CDM Federal Programs Comporation

Westinghouse Savannah River Company May 5,1993

Subcontract No. AA46325P

Task Order No. 10

\subsection{DISCUSSION}

The directional drilling and horizontal well installation technology used by CEC appears to be a sensible approach to horizontal well installations. However, the implementation of that technology was flawed by the inexperience of the drilling crew and therefore the technology cannot be fully evaluated.

\subsection{Analysis of the Drilling Program}

Factors which controlled the drilling performance are discussed below and include the following:

- Inexperience of the drilling crew.

- Ineffective drilling fluid system.

- Specific geologic conditions (clay percentage and highly permeable zones) and fluid losses.

- Deficient washover pipe.

- Other factors.

These factors will be discussed below.

\subsubsection{The Drilling Crew}

The CEC drilling crew consisted of two crews. The night crew worked from 7:00 pm to 7:00 am. The night crew chief was the Vice President of Operations for CEC. The day crew worked from 7:00 am to 7:00 pm. The day crew chief was operating the drilling rig for the first time. It was not a coincidence that the washover pipe usually broke when the day crew chief was drilling. Both crews were relatively inexperienced in deep (greater than 50 feet vertical depth) environmental well installation.

The inexperience of the drilling crews was demonstrated in their inability or reluctance to adapt their drilling methods to the site-specific drilling conditions. Two aspects of their drilling method which needed to be adapted for this drilling project were washover pipe installation and the drilling fluid system.

CEC claims that the washover pipe was deficient (discussed below). The joints of the washover pipe were too weak to withstand the oblique stresses experienced while the pipe was - rotated and/or pushed through the curved section of the borehole. After the first attempt at constructing the AMH- 6 borehole failed, the radii of curvature of the borehole paths were increased from 300 feet to 400 feet. The increased radius of curvature was supposed to decrease the oblique stresses experienced by the joints of the washover pipe. No other changes were made in the drilling operation to prevent the washover pipe joints from breaking until well into the project after the washover pipe had broken numerous times. Changes that were made included rotation of the washover pipe slowed to approximately $30 \mathrm{rpms}$ and the push pressure reduced. By that time, the washover pipe was well wom and more fragile, and the changes did not significantly improve the drilling performance.

Drilling fluid circulation was often lost during the drilling project. The drilling crew used the following methods to mitigate the fluid loss: 
Demonstration of River Crossing Technology for Installation of Environmental Horizomtal Wells: AMH-6 and AMH-7 Installation Report CDM Fecteral Programs Comporation

May 5.1993
Westinghouse Savannah River Company Subcontract No. AA46325P Task Order No. 10

1. The drill crew thickened the drilling fluid by quickly mixing the guar gum at a rate that prevents total dissolution of the guar gum in the drilling fluid. The result was clumps of guar gum powder (known as "fish eyes") that float in the drilling fluid. The purpose of the fish eyes was to flow into and plug any cavities in the area of the borehole that were experiencing the fluid loss.

2. The drill crew drilled the washover pipe past the zone where drilling fluid was being lost. This method only regains fluid circulation while drilling the pilot drill stem and is not effective if fluid loss occurs while advancing the washover pipe.

These two methods of drilling fluid loss mitigation may work at some drilling sites; however, they did not work at this site. The crew kept trying the above listed methods over and over again, regardless of the efficacy of their efforts. Alternate drilling fluid loss mitigation methods are discussed below.

The ineffectiveness of the drilling crews to deal with these two drilling challenges resulted in many additional man hours of drilling, loss of drilling fluids to the formation, and because drilling fluid loss caused the washover pipe to become stuck in the borehole, loss of drilling materials.

\subsubsection{The Drilling Fluid System}

CEC uses a guar gum-based drilling fluid on all their environmental horizontal well installation drilling projects. CEC distributes information on guar gum in their informational brochures (Appendix F). Guar gum-based drilling fluid is a natural organic polymer additive which overcomes problems associated with conventional drilling fluids. Guar gum-based drilling fuid systems have the following advantages. Formation damage is minimized because the fuid does not introduce clays to the borehole and formation. Drilling tool penetration rates are increased because the fluid reduces friction on the drilling tool.

A guat gumbased drilling fluid also has disadvantages. A guar gum-based drilling fluid has virtually no gel strength. Gel strength is a measure of the ability of the drilling fluid to maintain cuttings in suspension. When fluid circulation is stopped or lost, drill cuttings will settle to the bottom of the borehole. Once cuttings settle out of the fluid they will remain at the bottom of the borehole until the fluid velocity becomes great enough to once again entrain the cuttings in the fluid. The drilling fluid velocity can be increased by increasing the fluid pressure at the drilling tool.

A second disadvantage is at high temperatures a guar gum-based drilling fluid tends to "break down" or lose viscosity more quickly. This is in part due to the growth of certain microorganisms which are most prolific at $80^{\circ}$ to $120^{\circ} \mathrm{F}\left(27-49^{\circ} \mathrm{C}\right)$. Enzymes produced by these organisms in addition to those inherent in the guar gum-based drilling fluid can cause the breakdown of guar gum-based drilling fluid to be accelerated. Where such microorganisms or soil bacteria are likely to be present, precautions should be taken. If the mud pit is earthen, it should be lined with plastic. The mix water should be disinfected by chlorinating to $100 \mathrm{ppm}$. During the project, the mud pit quickly lost its plastic liner, and the mix water was not disinfected. 
A third disadvantage is that if the guar gum-based drilling fluid has penetrated into a very permeable formation it will temporarily reduce the well's efficiency which could result in inaccurate test pumping data. To remove this fluid, the well should be developed by high velocity horizontal jetting with $1,000 \mathrm{ppm}$ chlorine solution which will break down the guar gum-based drilling fluid. The wells installed during this project were not developed in this manner.

The drilling fluid system was inefficient for two reasons: (1) the drilling system was inefficient in removing drill cuttings, and (2) the guar gum-based drilling fluid was inefficient in maintaining fluid circulation. These two items are discussed below.

\section{Removal of Drill Cuttings}

The drilling system was inefficient in removing drill cuttings because the carrying capacity of the drilling fluid was not sufficient to remove drill cuttings from the borehole. The carrying capacity of the drilling fluid was affected by the gel strength of the fluid, the velocity of the fluid, and the fine sediment content of the fluid.

The crew increased the viscosity of the guar gum-based drilling fluid to increase the gel strength of the fluid and to stop fluid loss (described below). However, the gel strength of the guar gum-based drilling fluid remained less than the gel strength of a bentonite-based drilling fluid with the same viscosity. Whenever drilling fluid circulation stopped, the larger fractions of the entrained cuttings settled from the fluid to the bottom of the borehole. Because the borehole was either horizontal or at a low angle the cuttings remained in the borehole until the fluid velocity became great enough to erode the cuttings from the bottom of the borehole. The SRTC representative suggested to CEC personnel that the fluid velocity should be increased to remove cuttings. The CEC drilling $\mathrm{crew}$ did not increase the fluid velocity to remove drill cuttings from the borehole.

The drilling fluid system contained one small desander that early in the drilling project proved ineffective in removing fine sediments from the drilling fluid. The purpose of the desander was to remove fine sediments from the drilling fluid as it circulated from the borehole to the mud mixing tank. Drilling activities were stopped numerous times to allow the drilling crew to remove fine sand from the mud mixing tank that should have been removed by the desander. The desander was not replaced and remained inefficient throughout the drilling project. The results of the ineffectiveness of the desander were that the carrying capacity of the drilling fluid was greatly reduced and drill cuttings remained in the borehole. The drill cuttings remaining in the borehole quite possibly contributed to the washover pipe sticking and breaking numerous times. Cuttings that remain in the borehole will form a bridge between the drill pipe and the borehole wall. The bridge will act as a wedge when the drill pipe turns, and the drill pipe will become stuck.

\section{Loss of Drilling Fluid Circulation}

Two methods are available to stop drilling fluid loss. The first method requires an extremely viscous guar gumbased drilling fluid, 120 Marsh funnel seconds or more. A mass of this freshly mixed highly viscous guar gum-based drilling fluid must be spotted in the hole opposite the lost circulation zone. Enough of this guar gum-based drilling fluid to twice fill the borehole 
Demonstration of River Crossing Technology for Installation of civiromental Horizontal Wells: AMH -6 and AMH-7 lnstallation Report CDM Federal Programs Corporation

May 5,1993
Westinghouse Savannah River Company Subcontract No. AA46325P

Task Order No, 10

annulus should be mixed in a separate tank or pit and pumped through the drill pipe to this zone. The drill pipe is then pulled back allowing the viscous guar gum-based drilling fluid to migrate into the permeable zone, thus sealing it off. After about 30 minutes, the viscosity of the remaining fluid can be reduced, and normal drilling can resume. The drill crew used a similar approach to mitigate fluid loss. The drill crew did mix a viscous guar gum drilling fluid (described above), but they did not have a Marsh funnel to measure viscosity, and they did not pull back the drill pipe to the loss circulation zone and pump the viscous drilling fluid into the permeable zone.

The second method to mitigate drilling fluid loss involves mixing Borax with the guar gumbased drilling fluid to create a dense, rubbery plugging material. Onsite experimentation with a few quarts of fluid is useful to determine mix ratios but generally one can proceed as follows:

1. Mix one cup of "20 Mule Team Borax" in 5 gallons of water, then pour the borated water directly into the drill stem.

2. Mix a pit of highly viscous guar gum-based drilling fluid - about 120 Marsh funnel seconds.

3. Raise the pH of this fluid to 9.0 to 9.5 by adding soda ash as needed. Start by dissolving a cupful of soda ash per 1,000 gallons of water and slowly add to circulating fluid system at the pump suction. System $\mathrm{pH}$ should be checked periodically while circulating and should be kept below 10 to avoid polymer destruction.

4. Mix additional borated water at the ratio of one cup borax per 5 gallons of water.

5. Place bottom of drill stem opposite lost circulation zone.

6. Raise pump suction to near pit surface level.

7. Activate pump at idling speed and when the drilling fluid starts to flow, pour borated water into the pit near the pump suction. Continue pumping until borated gel appears at ground surface in the annulus between drill stem and bore. It will be a thick, gelled mass.

8. Shut pump down immediately to prevent gel from reaching pit.

9. Pull drill stem back one or two lengths and wait 30 minutes for gel to cure.

10. Resume drilling operation with pump operating at reduced speed until several feet of new formation has been penetrated.

11. Repeat entire operation if necessary. If used in an aquifer where a screen has been set, it may be necessary to develop the well by high velocity jetting with a 1,000 ppm chlorine solution.

The gelled fiuid may be retumed to its starting viscosity by reducing the pH to 7 or lower. Reducing the amount of guar gum-based drilling fluid or Borax used or using a pH above 7 but less than 9 will weaken the chemical cross-linking bond of the guar gum polymer and produce a partially gelled, stringy mass that can be easily pumped or circulated. This partially cross linked gel can be used where excessive fluid loss is a problem as, for example, when encountering coarse sand and gravel or other highly permeable zones.

The SRTC representative strongly suggested to CEC that they should try this method to stop drilling fluid loss. The CEC drill crew did not apply this method. 
Demonstration of River Crossing Technology for Installation of Environmental Horizontal Wells: AMH-6 and AMH-7 Installation Report CDM Fetieral Programs Corporation May 5,1993
Westinghouse Savannah River Company Subcontract No. AA46325P Task Order No. 10

\subsubsection{Specific Geologic Conditions and Fluid Losses}

The specific geologic conditions that created difficulties during drilling were the clay content of sediments and sporadic, high permeability zones within the target horizon. The geologic cross section provided to CEC by SRTC showed that the target horizon was generally silty sand to silty, clayey sand. The drilling plan submitted to SRTC by CEC acknowledged the possibility of the presence of clay and/or clayey silt/sand horizons. The drilling plan provided for the use of a down-hole drilling motor if drilling conditions became too difficult for the hydraulic spudjet drill bit. CEC did not bring a downhole drill motor to the site nor did they send for one when drilling conditions became too difficult for the hydraulic spud-jet. While drilling the AMH 7 borehole, the drilling rate was as slow as 10 feet of pilot hole drilled per 90 minutes. The reluctance of CEC to adapt to drilling conditions added many hours to the drilling project.

The nature of the high permeability zones within the target horizon is unclear. Regardless of the cause of the loss of drilling fluid circulation, the fact remains that CEC did not adapt their drilling method or fluid system to meet site conditions.

\subsubsection{Drill Rod Type}

The 4130 heat-treated two-inch steel pilot drill pipe used proved to be adequate for drilling in the coastal plain sands and clays. However, the 2160 washover pipe (used by mistake instead of 4130 pipe) proved to be inadequate. This type of washover pipe broke on several occasions with the box of the downhole pipe breaking off on the pin of the pipe above it. Later in the drilling project, 4130 washover pipe was shipped to the drill site and used to extract the broken sections of 2160 pipe. No problems were encountered with any of the new 4130 washover pipe.

\section{1 .5 Other Factors}

\section{Drilling Tool}

The Task Management Plan provided by CEC stated that a drill motor and hydraulic spud-jet system would be used on this project. CEC chose to provide only a hydraulic spud-jet system at the site. However, the clayey nature of the target horizon dictated that a drill motor was required. These wells could have been completed more efficiently by using the drill motor.

\section{Steering System}

The steering system is the most accurate system avallable. The survey crew must calibrate the tool before drilling begins. The drilling method used by CEC required that the control wire that connects the downhole steering probe with the surface control unit be spliced twice at the beginning of each ten-foot run. Normal drilling operations require only one splice. The second splice added more time to the drilling operation and provided another weak spot in the wire. The wire will break at weak spots and cause failure of the steering system. System failure required extracting the pilot string from the borehole, resulting in significant drilling delays. 
Demonstration of River Crossing Technology for Installation of Envirommental Horizontal Wells: AMH-6 and AMH-7 Installation Report CDM Federal Prograus Comporation

May $\$, 1993$
Westinghouse Savannah River Company

Subcontract No. AA46325P

Task Order No. 10

\section{Drilling Rig Anchorage}

Anchors were placed at the front of the drilling rig by driving two 10-foot sections of four-inch diameter washover pipe into the ground and welding them to the frame of the drilling rig. The drilling rig anchors became loose due to excessive pushing and pulling and had to be periodically welded back to the frame. The standard anchor system for the drilling rig consisted of a hydraulic ram and a "dead man" (Section 4.1.1). The standard anchor system was never employed by CEC.

\subsection{Analysis of the Well Installation Method}

The well installation method is described in Sections 6.3 and 6.5 . While this method is intuitively simple, it does put stress on the well materials. At any given time each section or joint in the well string experiences the following components of stress:

Compression - Compression is exerted on the well materials when the drilling rig must be used to push the well construction material from the surface. This technique is necessary to overcome downhole frictional forces. If too much force is exerted, the screen may collapse.

Weight - The weight of the well string is dependent on the mass of the well materials and upward or downward forces in the borehole. An example of upward force is buoyancy caused by fluid in the borehole. An example of a downward force is the weight of the well string.

This installation method is easy and efficient. The implementation of the method during this drilling project was flawed. Drilling mud was used to install the well materials in AMH-7. The drilling fluid contained a large fraction of fine sediments. The sediments remained in the well after the materials were pushed into place and well development was difficult. A clean, low viscosity, chlorinated drilling fluid should have been used to supply the hydraulic pressure needed to install the well materials.

There appeared to be no problems associated with installation of the sand, bentonite, and grout well seals in the wells.

\subsection{Well Development}

Well development for a soil vapor extraction well is difficult because there is no formation water to aid in flushing out the drilling mud. As discussed above, if a clean, low viscosity, chlorinated drilling fluid was used to apply hydraulic pressure to the well materials during well installation (instead of drilling fluid that contains abundant drill cuttings), then there would have been less sediments in AMH-7, and the guar gum-based drilling fluid would have been rendered biologically inactive. A water-flushing treatment of the well may have been deemed unnecessary if the well installation had been done properly. However, water-flushing of the well was performed. The water was not chlorinated and biological activity induced by the guar gum-based drilling fluid may cause reduction in formation permeability. 
Demonstration of River Crossing Technology for Installation of Environmental Horizontal Wells: AMH-6 and AMH-7 Installation Report

Westinghouse Savannah River Company CDM Federal Programs Corporation

Subcontract No. AA46325P

May 5,1993

Task Order No. 10

\subsection{CONCLUSIONS}

The following conclusions were reached upon completion of the river crossing directional drilling demonstration.

1. Two horizontal wells were successfully installed at $24 \pm 5$ feet msl (under the M-Area Settling Basin. Well AMH-7 was installed with a screen of 420 feet; well AMH-6 was installed with an effective screen of 230 feet (190 feet short of the proper length due primarily to the washover casing left in the borehole).

2. Formation damage could have been minimized by:

- Controlling fluid loss to the formation during borehole drilling.

- Using clean, chlorinated drilling fluid during well installation.

- Using clean, chlorinated water during well development.

3. The drilling crew was inexperienced in installing deep (greater than 50 vertical feet) horizontal wells. The crew's inexperience was demonstrated by their inability to: deal with adverse site specific drilling conditions; deal with loss of drilling fluid circulation; deal with an ineffective desander in the drilling fluid system.

4. A downhole drill motor would have improved drilling efficiency.

5. The drilling crew did not ensure that washover pipe of the proper strength was used during the drilling project. The radii of curvature of the boreholes ( 400 feet) were not large enough to ensure stability of the washover pipe.

6. The guar gumbased drilling fluid system was inadequate. The drilling fluid system should have been improved or a bentonite-based drilling fluid should have been considered. The drilling crew did not keep drilling records or mud reports during this project. Therefore, the drilling crew was unprepared to adapt to the site-specific drilling conditions.

7. The directional drilling and horizontal well installation method used during this project cannot be fully evaluated because the implementation of the method was flawed. However, at this time the method should be considered as an appropriate technology for installing horizontal wells. 
Demonstration of exver Crossing Technology for Installation of

Enviromented Horizontal Wells: AMH-6 and AMH 7 Installation Report

CDM Ecteral Programs Corporation

May 5,1993
Westinghouse Savannah River Company Subcontract No. AA46325P Task Order No. 10

THIS PAGE INTENTIONALLY LEFT BLANK 
Denonstration of piyer Crossing Technology for Installation of

Environmental Horizontal Wells: AMH-6 and AMH-7 Installation Report

CDM rederal Programs Corponation

May 5,1993
Westinghouse Savannah River Company

Subcontract No. AA46325P

Task Order No. 10

\subsection{RECOMMENDATIONS AND SUGGESTIONS FOR FUTURE ACTIVITIES}

\subsection{Recommendations}

The following are major recommendations for consideration if future projects of this nature are planned.

1. The drilling contractor should provide an experienced drilling crew. The drilling crew should be experienced in the following:

- Installation of a horizontal well in conditions similar to that found at the proposed drilling site.

- The use of all equipment used to install the horizontal well.

2. The drilling crew should make every effort to control the loss of drilling fluid circulation. Loss circulation zones should be plugged when they are encountered.

3. When using a guar gum-based drilling fluid, a chlorine additive should be used in the drilling fluid mix water and development water to disinfect the drilling fluid and inhibit bacterial growth. If the state Health Department does not allow a disinfectant to be introduce to the subsurface, then an alternate drilling fluid (such as a bentonite-based drilling fluid) should be used.

4. If hydraulic pressure is used to install the well materials, a clean, chlorinated, drilling fluid should be used. A clean drilling fluid would not introduce drill cuttings into the well materials that would increase well development efforts.

5. Drilling crews should be required to keep detailed daily records of drilling activities and drilling fluid properties. The records can be used to adapt drilling methods to site conditions.

6. Radii of curvature for the boreholes should be large enough to accommodate the drilling materials. Future drilling projects that use similar washover pipe should be designed to have a borehole with a radius of curvature greater than 400 feet.

7. Longer drill pipe and a wireless drilling survey system would greatly decrease the drilling time.

\subsection{Suggestions for Future Activities}

Based on the results of this field demonstration, the following suggestion is made regarding the future of horizontal wells AMH-6 and AMH-7. The efficiency of the horizontal wells are scheduled to be evaluated during the soil vapor extraction tests. If the horizontal well evaluations demonstrate a lower than expected soil gas permeability, then the wells should be developed with chlorinated water to destroy bacterial growth in the formation. 
Demonstration of River Crossing Technology for Installation of

Westinghouse Savannah River Company Exavironmental Horizontal Wells: AMH-6 and AMH-7 Installation Report

CDM Federal Programs Corporation

Subcontract No. AA46325P

May $\$, 1993$

Task Order No. 10

\section{THIS PAGE INTENTIONALLY LEFT BLANK}


Demonstration of River Crossing Technology for Installation of Environmental Horizontal Wells: AMH 6 and AMH-7 Installation Repor CDM Foderal Programs Comporation

May 5,1993
Westinghouse Savannah River Company

Subcontract No. AA46325P

Task Order No. 10

\section{REFERENCES}

Aadland, R.K., Smits, A.D., and Thayer, P.A., 1992, Geology and Hydrostratigraphy of the A/M Area, Savannah River Site (SRS), South Carolina (U)

CDM Federal Programs Corporation, 1992, Hydrogeologic Setting of the A/M Area: Framework for Groundwater Transport, Second Draft, WSRC-TR-92-355.

Eddy, C.A., Looney, B.B., Dougherty, J.M., Hazen, T.C., and Kaback, D.S., 1991, Characterization of the Geology, Geochemistry, Hydrology and Microbiology of the In-Situ Air Stripping Demonstration Site at the Savannah River Site, USDOE Report WSRC-RD-9121. Westinghouse Savannah River Co., Savannah River Laboratory, Aiken, SC 29808, 118 p

Huddleston, D.F., and Hetrick, J.H., 1985, Upper Eocene Stratigraphy of Central and Eastern Georgia. Georgia Geologic Survey Bulletin 95, 78 p

Nystrom, P.G., Ir., and Willoughby, R.H., 1982, "Cretaceous, Tertiary, and Pleistocene(?) Stratigraphy of Hollow Creek and Graniteville Quadrangles, Aiken County, South Carolina", in Nystrom, P.G., Jr., and Willoughby, R.H., eds., 1982, Geological Investigations Related to the Stratigraphy in the Kaolin Mining District, Aiken County, South Carolina. Carolina Geological Society Field Trip Guidebook 1982, South Carolina Geological Survey, Columbia, $\mathrm{SC}$, pp $80-113$

Nystrom, P.G., Jr., Willoughby, R.H., and Kite, L.E., 1986, Cretaceous-Tertiary Stratigraphy of the Upper Edge of the Coastal Plain Between North Augusta and Lexington, South Carolina. Carolina Geological Society Field Trip Guidebook, South Carolina Geological Survey

Science Applications International Corporation, 1992, Construction Notes and Summary of Hydrostratigraphy for Hydrogeologic Cross-Sections for the Integrated Demonstration Site, Savamnah River Site. SAIC, 360 Bay Street, Suite 200, Augusta, GA 30901

Siple, G.E., 1967, Geology and Groundwater of the Savannah River Plant and Vicinity, South Carolina. U.S. Geological Survey Water-Supply Paper 1841,113 p 
Demonstration of hiver Crossing Technology for Installation of Exvironmental Horizontal Wells: AMH-6 and AMH-7 Installation Report CWM Federal Programs Corporation

May 5,1993
Westinghouse Savannah River Company Subcontract No. AA46325P Task Order No. 10

THIS PAGE INTENTIONALLY LEFT BLANK 
Demonstration of River Crossing Technology for Installation of

Westinghouse Savannah River Company

Environmental Horixontal Wells: AMH 6 and AMH-7 Installation Report

CDM Foderal Programs Corporation

Subcontract No. AA46325P

May $\$ .1993$

Task Order No. 10

\section{APPENDIX A}

\section{SUMMARY OF BROKEN WASHOVER PIPE RECOVERY ACTIVITIES}


Demonstration of River Crossing Technology for Installation of Environmental Horizontal Wells: AMH-6 and AMH-7 Installation Report CDM Fecteral Programs Corporation

May 5,1993
Westinghouse Savannah River Company Subcontract No. AA46325P Task Order No. 10

THIS PAGE INTENTIONALLY LEFT BLANK 
Demonstration of River Crossing Technology for Installation of Enwironmental Horizontal Wells: AMH-6 and AMH-7 Installation Report COM Federal Programs Corporation May 5,1993
Westinghouse Savannah River Company

Subcontract No. AA46325P

Task Order No. 10

\section{A. SUMMARY OF BROKEN WASHOVER PIPE RECOVERY ACTIVITIES}

Section 6.0 of this report provides detailed drilling activities for AMH-6 and AMH-7. This appendix provides a detailed account of the broken washover pipe recovery activities during the two attempts to install AMH-6. Refer to Appendices B and C for Daily Activity Reports for the period of November 11, 1992 to December 15, 1992 and for drilling photographs, respectively.

\section{A.1 First Attempt at Drilling of AMH-6 and Subsequent Fishing Activities}

Drilling began on Hole \#2 (AMH-6) on November 13, 1992. The pilot drill stem was advanced to 570 feet $\mathrm{MD}$ and the washover pipe to 350 feet $\mathrm{MD}$ before significant drilling fluid losses began to occur. Installation of the washover pipe continued until washover pipe \#54 ( 540 feet $\mathrm{MD}$ ) could not be advanced and the decision was made to trip out the washover pipe to determine if the washover pipe had broken. The driller pulled off only 32 joints of washover pipe before encountering the end of the drill string. The washover pipe had broken off at the box of joint 22 , leaving 21 joints (210 feet) of washover pipe down hole with the top of the broken section approximately 310 feet MD down hole.

On November 15,1992 at 2100 hours, drilling was halted until a fishing tool could be flown in to extract the broken pipe. The fishing tool (Fig. A-1) arrived on November 17, 1992 at 0700 hours. The fishing tool, designed as an overshot barrel, was attached to the end of the washover pipe. This device was then advanced over the broken section of washover pipe and rotated to grind off any anomalous metal from the end of the broken pipe. A sleeve within the fishing tool locks on to the broken section of pipe for extraction.

The drillers attempted to push the fishing tool down to the broken section of washover pipe; however, the hole was too tight to detect when the tool encountered the broken string. The drillers tripped out the fishing tool, went back into the hole with a nine-inch rotary bit to widen the borehole, and advanced it down to within two feet of the broken string. The rotary bit was tripped out and the fishing tool reinserted. On November 18,1992 at 0430 hours, the fishing tool was successfully attached to the broken washover pipe; however, the drilling rig was unable to move or rotate the washover pipe. The decision was made to pull the two-inch drill string, with the Non-Magnetic Bottom Hole Assembly (BHA) resting approximately 80 feet past the end of the broken washover pipe. The BHA was retracted into the broken string until it reached the fishing tool but would move no further. The opening in the fishing tool was too small for the BHA to pass, so the BHA was advanced back down past the broken string. At 1500 hours on November 18,1992 the decision was made to order a vibrating hammer and a spare BHA.

The vibrating hammer (Fig. A-2) arrived on site November 24, 1992 at 1040 hours. The crane provided by EMTC was not capable of lifting the hammer off the truck. A new crane was ordered and arrived at 1600 hours. The hammer was attached, and the rig began attempting to move the washover pipe. Utilizing both the pulling power of the drilling rig and the vibration of the hammer, the pipe began to move. The fishing tool appeared at the collar of the borehole, but no washover pipe was attached. Now that the fishing tool was out of the way, the BHA was extracted and the hole abandoned. The crew pulled all of the two-inch pilot string with the BHA out of the hole and moved to Hole \# (AMH-7). 
Demonstration of River Crossing Technology for Installation of Exviroamental Horizontal Wells: AMM-6 and AMH-7 Installation Report CDM Federal Programs Corporation

May 5, 1993
Westinghouse Savannah River Company

Subcontract No. AA46325P

Task Order No. 10

The total estimated drilling fluid lost to the formation during the first attempt at installing AMH -6 was 31,000 gallons. This volume was unacceptable, and attempts were made during the drilling of AMH-7 to minimize this loss.

\section{A.1 Second Attempt at Drilling of AMH-6 and Subsequent Fishing Activities}

Drilling began on AMH-6 on November 25, 1992 at 2100 hours. Pilot hole drilling proceeded to 511 feet MD and washover pipe to 350 feet MD before the washover pipe again broke downhole.

The washover pipe had broken between joints \#6 and \#7 downhole ( 270 feet MD) with the box of joint still attached to the pin of joint \#7. This relationship of the box breaking off on the pin of the previous pipe has been the same for each of the pipe failures for this project. The broken section of six washover pipes rested between 270 and 330 feet $\mathrm{MD}$. The driller tripped out the BHA and replaced it with a two-inch dummy string to 510 feet. The washover pipe was then advanced down to the top of the broken section with a nine-inch drill bit to increase the diameter of the hole for installation of the fishing tool. Because the broken section of washover pipe was encountered a few feet shallower than expected, the driller felt that it may be loose and decided to use a hook instead of the fishing tool to retrieve the pipe. The two-inch dummy string was tripped out of the hole, and the hook (Fig. A-3) was attached to the end. The hook was then pushed back downhole and passed out the end of the broken string. To grab the broken section of pipe, the hook was pulled back slowly past the estimated point of the end of the broken washover pipe and by placing a hand on the two-inch pipe as it was retracted, contact with the broken section could be felt. If the hook was retracted beyond the estimated downhole end of the pipe, then it was advanced back down past the end of the pipe and rotated $90^{\circ}$ and the process repeated.

Contact with the broken string was achieved, and the crew began pulling the pipe back. Every time a section of the two-inch retrieving pipe was removed from the rig, the driller would push the hook back down the hole approximately two feet and begin pulling slowly again until contact with the broken washover pipe was felt. This process continued until the hook reached 160 feet MD. During the attempt to pull joint \#16 no contact could be felt with the broken string. The driller decided to continue pulling the hook, but there was no broken washover pipe attached when it reached the surface. The hook was advanced back down the hole, past the broken string and reattached to the end of the broken string. Extraction resumed and when the broken section emerged at the surface, the hook was attached to the outside of the broken string.

The crew proceeded to reinstall the pilot string with the BHA back down to 511 feet MD and the washover pipe to 330 feet $\mathrm{MD}$. Drilling began again on the washover pipe and proceeded to 405 feet MD where the point of rejection was reached. It appeared that the washover pipe had again broken at some point in the curve.

The crew decided to trip out the two-inch pilot string and reinstall the two-inch string with the hook, using the washover pipe as a guide to the bottom. Once the hook was installed, the washover pipe was pulled to determine the location of the separation. The break occurred between washover joints \#8 and \#9 ( 325 feet MD) with the box of joint \#8 still attached to the pin of joint \#9. The eight joints left in the hole were between 325 and 405 feet MD. The drill 
Demonstration of River Crossing Technology for Installation of Environmental Horizontal Wells: AMH-6 and AMH 7 Installation Report CDM Fockal Programs Corporation May 5,1993
Westinghouse Sayamah River Company

Subcontract No. AA46325P

Task Order No. 10

crew used the same technique described above for removal of the broken washover pipe. The broken string was removed without incident.

The driller tripped the two-inch pilot string with the BHA back into the hole to 511 feet $\mathrm{MD}$ and the washover pipe to 405 feet MD. The drillers decided to use lower rotational speed and pull down force to put less strain on the washover pipe. The rates agreed on by CEC and the SRTC representative were that pull down force not exceed $800 \mathrm{lbs}$ and rotational speed not exceed 30 rpms. At this point, a major concern was the amount of strain that had previously been put on the washover pipe was a major concem for the rest of the drilling program.

Drilling of the washover pipe resumed with mud losses to the formation becoming significant. The dnill crew completed pushing the washover pipe to 490 feet $\mathrm{MD}$; however, fluid losses to the formation reached 1000 gallons per twenty feet drilled or approximately 1000 gallons every 40 minutes. Drilling efforts again shifted to the pilot string and progressed to joint \#61 (611 fet $\mathrm{MD}$ ).

The drill crew attempted to move the washover pipe 63 (631 feet MD), but it was stuck. The rig continued to pull on the washover pipe until it moved suddenly. This indicated that the washover pipe had probably broken downhole. The break occurred between washover joints $\# 42$ and $\# 41$ ( 80 feet $M D$ ) with the box of joint \#41 still attached to the pin of joint \#42. The 40 joints left in the hole were between 80 and 480 feet $\mathrm{MD}$. If the well could be drilled out to the end of the original project distance, then even if the washover casing was left in the hole there could be 270 feet of effective screen below the basin. SRTC personnel were informed of the massive fluid losses and the broken washover pipe. The decision was made by SRTC personnel to accept the well with 250 to 280 feet of effective screen below the basin if the washover casing could not be removed. Because of the massive fluid losses to the formation and the problems with the integrity of the washover pipe, a replacement well would be drilled only if all other attempts at salvaging the current borehole failed.

The drill crew tripped out the two-inch pilot string with the BHA and reinstalled the hook to pull on the downhole end of the broken string. They also reinstalled the fishing tool to attach to the upper end of the broken string. In retrospect, it was not a good idea to use both of these tools together. Once the fishing tool was attached to the upper end of the broken string, it became impossible to retract the hook back through the fishing tool. The drill crew began pulling on the two-inch hook in an attempt to move the pipe; however, the hook broke off downhole from the two-inch string. The two-inch string was extracted to determine where the break occurred. All of the sections of two-inch pipe emerged from the borehole with the exception of the four-inch long hook. The driller felt a two-inch pipe with a plug on the end could be pushed downhole and the broken hook either pushed to the end of the hole or laterally into the borehole wall. The crew tripped a dummy two-inch string back down the borehole, past the end of the broken washover pipe, to act as a guide. The drill crew prepared to hook up the vibrating harnmer to the four-inch washover pipe.

The hammer was engaged, and the coupling on the washover pipe directly below the hammer began to separate. The drill crew cut in half a two-foot long section of four-inch steel washover pipe and welded it over the coupling to stabilize the link. The vibrator was again engaged, but the plate attaching the hammer to the four-inch washover pipe broke. The drill 
Demonstration of River Crossing Technology for Installation of Wextinghouse Savamnab River Company Environmental Horizontal Wells: AMH-6 and AMH-7 Installation Report

Subcontract No. AA46325P

CDM Federal Programs Corporation

Task Order No. 10

May 5,1993

crew decided to stop work for the night and ordered a D-8 bulldozer for the morning to provide added pulling capabilities.

The D-8 bulldozer arrived on site at 1000 hours the next moming. The drill crew hooked the winch of the bulldozer up to the four-inch washover pipe and began to pull. The pipe began to move until ten feet of washover pipe was exposed. The section of pipe was removed, and the string reattached to the drilling rig. The rig could not advance the string, even with the assistance of the bulldozer. The hammer was reattached and engaged, but the washover pipe broke apart four joints below the surface. Because the fishing tool was still downhole, the drill crew had to stop work for the day and order another fishing tool. Work was stopped on December 1, 1992 at 1600 hours.

The new fishing tool arrived late in the afternoon of December 2, so work resumed at 0700 hours of Decernber 3. The fishing tool reached the broken washover pipe at 46 feet MD. Pulling was intiated at 1000 hours utilizing both the drilling rig and the bulldozer together. The pipe failed to move after three hours of continuous pulling. A second D-8 bulldozer was ordered and arrived at 1420 hours. The drilling rig and the two bulldozers in tandem pulled on the pipe for one hour before the washover pipe broke. The crew retracted the washover pipe and recovered both fishing tools and 13 joints of washover pipe below the lower fishing tool. At this point 28 joints of washover pipe remained in the ground between 200 and 480 feet MD. The drill crew reinstalled the fishing tool, attached to the broken washover pipe, and began pulling and hammering with the drilling rig and the two bulldozers in tandem. The plate that attaches the washover pipe to the hammer broke, and a new plate was fabricated. The new plate was attached and pulling resumed, but the pipe broke again. This time the box of the fishing tool broke off on the pin of the washover pipe, leaving no surface for attaching another fishing tool.

The drill crew attached a spear to the washover pipe and advanced it down into the broken fishing tool. Several attempts were made at pulling the broken string out of the borehole with the spear, but the drilling rig could never advance the spear far enough into the fishing tool to get solid link. The drillers decided to try to disengage the fishing tool from the broken string by rotating the spear counterclockwise and pulling with light force. This effort was successful, and the fishing tool was removed from the borehole.

The drill crew reattached the BHA and began pushing the pilot string back down the borehole. Upon reaching the top of the broken section of the washover pipe (approximately 200 feet MD), the BHA would not pass in to it. A splayed coupling was prepared from a section of washover pipe to fit over the broken end downhole. This provided a guide to allow the BHA to pass. The pilot string passed out of the broken washover pipe but encountered the remains of the hook. The driller was successful in pushing the hook laterally into the wall of the borehole. A major concern was the possibility of the hook washing out of the wall of the borehole and preventing the extraction of the BHA. The BHA was extracted, and the well was installed.

After well installation, the drill crew atternpted to remove the extra washover pipe that had been installed from the surface down to the top of the broken section; however, the pipe would not move. Sand had apparently settled in around the splayed end of the washover pipe, preventing it from being extracted. Instead of risking damage to the installed well, the drill crew rotated 
Demonstration of River Crossing Technology for Installation of Ervironmental Horizontal Wells: AMH 6 and AMH 7 Installation Report CDM Federal Trograms Corporation

May 5,1993
Westinghouse Savannah River Company Subcontract No. AA46325P Task Order No. 10

the washover pipe counterclockwise to unscrew as much of the pipe as possible. Only 6 sections of washover pipe were extracted, leaving 420 feet of washover casing down the hole from 60 to 480 feet $\mathrm{MD}$. 
Demonstration of River Crossing Technology for Installation of

Westinghouse Savannah River Company

Environmental Horizontal Wells: AMH-6 and AMH-7 Installation Report

CDM Federal Programs Comoration

Subcontract No. AA46325P

May 5, 1993

Task Order No. 10

THIS PAGE INTENTIONALLY LEFT BLANK 
Demonstration of kiver Crossing Technology for Instaltation of Environmental Horkmtal Well: AMH.6 and AMH-7 Installation Repon CDM Fedstal Protrams Comporation Mury 5,1993
Westinghouse Savamah River Company Subcontract No. AA46325P Task Order No. 10

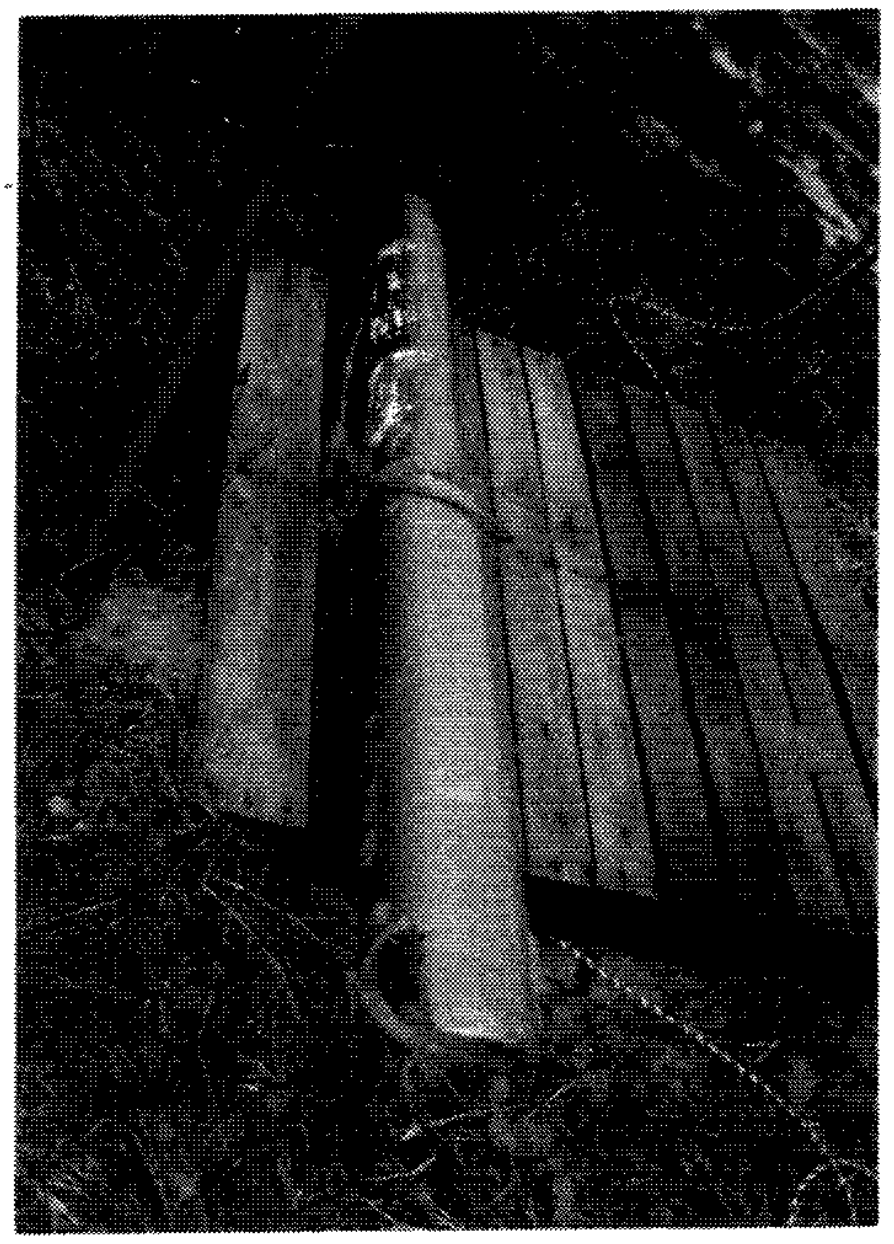

Oblique view of the fisking tool used as an overshot to attach on to the broken section of four. inch waskover pipe.

Figure A-1. Fishing Tool for Extraction of Broken Washover Pipe 
Demonstration of River Crossing Technology for Installation of Environmental Horizontal Wels: AMH 6 and AMH+7 Installation Repor CDM Feteral Programs Corporation May 5,1993
Westinghouse Savannah River Company Subcontract No. AA46325P Task Order No. 10

\section{THIS PAGE INTENTIONALLY LEFT BLANK}


Gemonstration of River Crossing Techology for Installation of

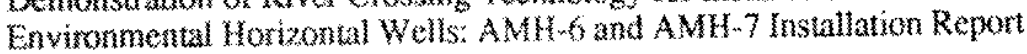
CDM Foural Fromams Corporation

May 5,1993
Westingthouse Savannat River Company Subcontract No. AA6325P Task Order No. 10

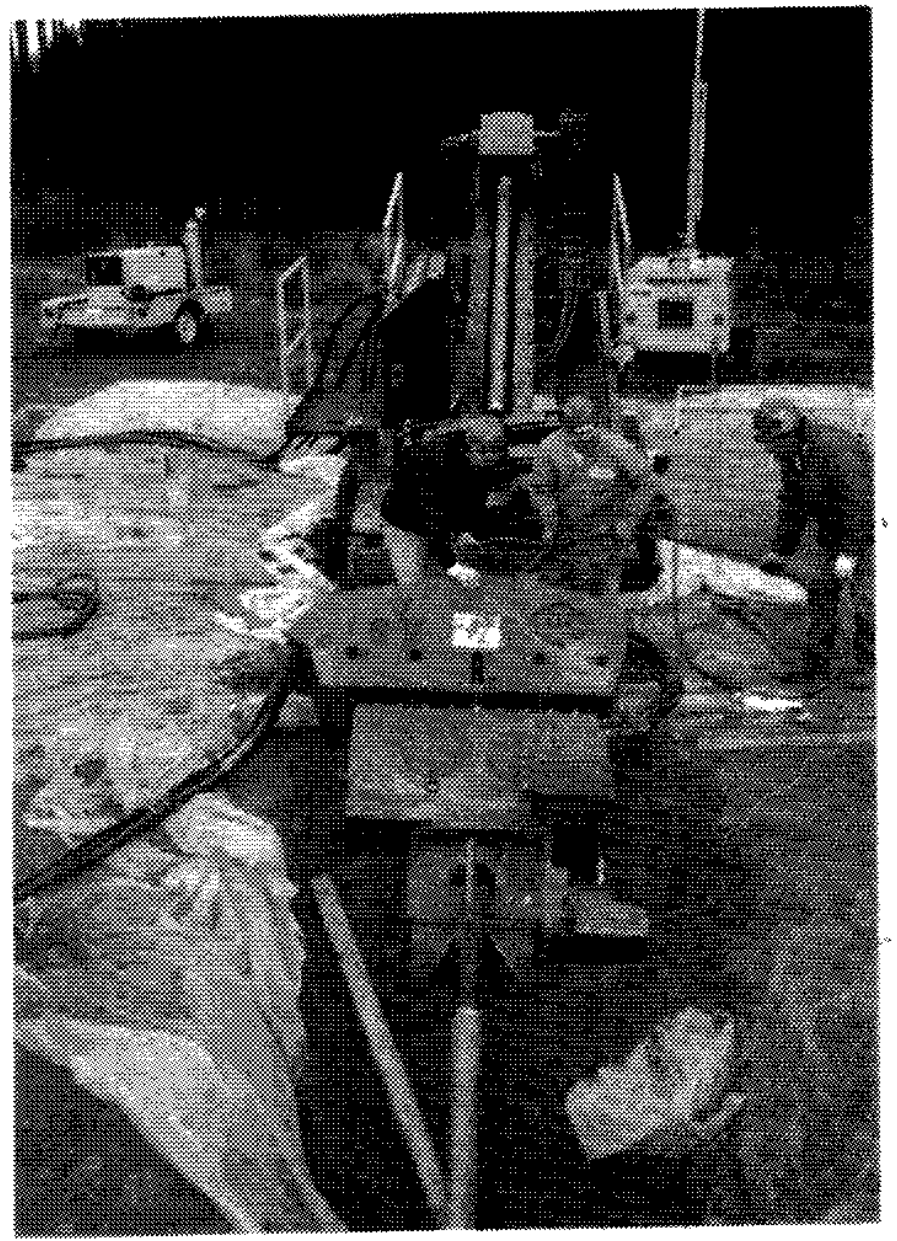

Vibrating hammer was attached to the washover pipe and vibrated with a pushing and pulling motion.

Wigure A.2. Vibrating Hammer for Extraction of Broken Washover Pipe 
Demonstration of River Crossing Technology for Installation of Environmental Horizontal Wells: AMH -6 and AMH. 7 Installation Report CDM Federal Programs Corporation

Westinghouse Savannah River Company

May 5,1993

Subcontract No. AA46325P

Task Order No. 10

THIS PAGE INTENTIONALLY LEFT BLANK 
Demonstration of River Crossing 'Tachnology for Instatlation of Environmental Horizontal Wells: AMH 6 and AMH.7 Installation Repon CDM Federal Prourans Corporabon May 5,1993
Westinghouse Savannah Rivet Company Subcontract No. AA46325P Task Order No. 10

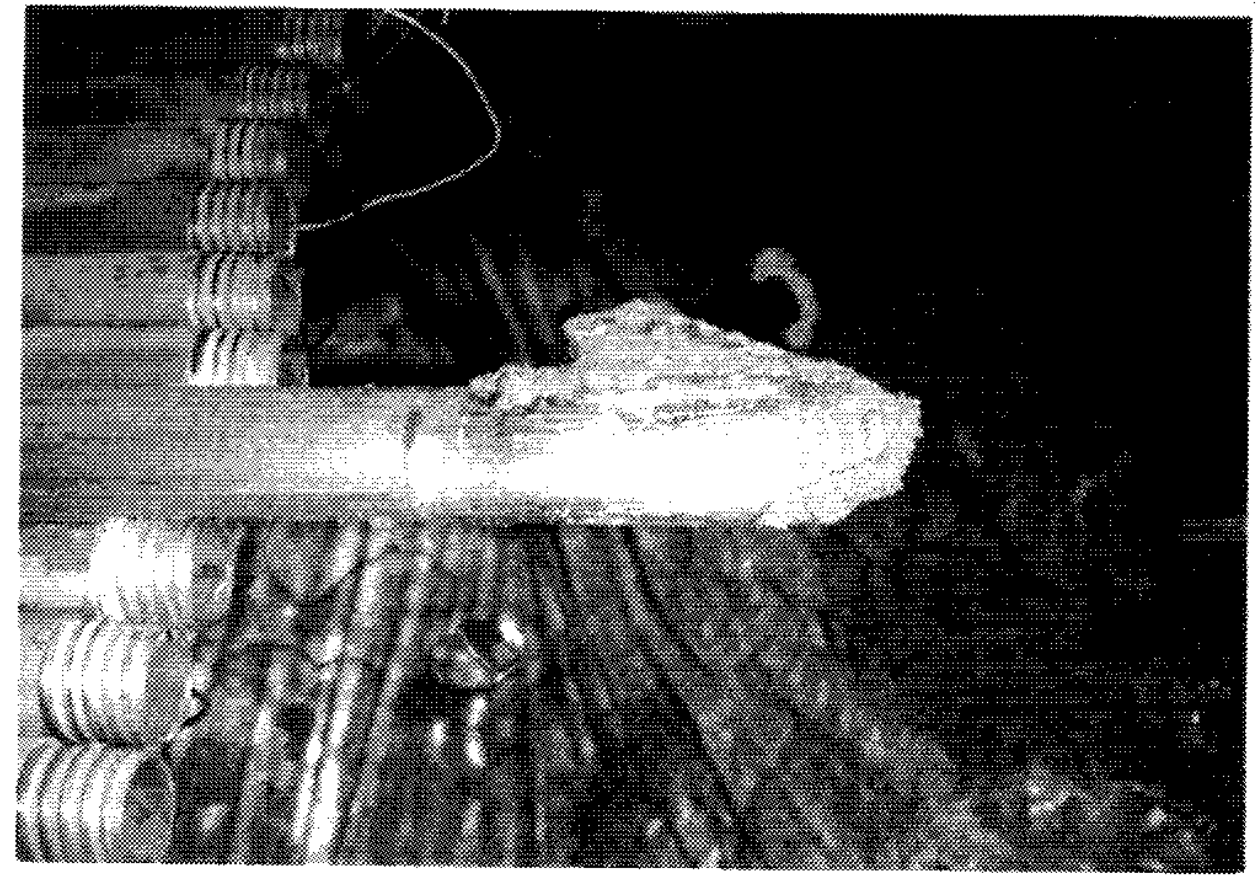

This hook was advanced down the inside of the four inch washover pipe atached to the two inch pilot string. The hook was passed out the end of the broken washover pipe and retracted whil the hook latened on to the downhole end of the broken section of pipe.

Figure A-3. Twownch Diameter Hook for Extraction of Broken Washover Pipe 
Demonstration of River Crossing Technology for Installation of Environmental Horizontal Wells: AMH-6 and AMH-7 Installation Report CDM Federal Programs Corporation

May 5, 1993
Westinghouse Savannah River Company

Subcontract No. AA46325P Task Order No. 10

THIS PAGE INTENTIONALLY LEFT BLANK 
Demonstration of River Crossing Technology for Installation of Environmental Horizontal Wells: AMH-6 and AMH-7 Installation Repon CDM Federal Programs Corporation

May 5, 1993
Westinghouse Savannah River Company

Subcontract No. AA46325P

Task Order No. 10

\section{APPENDIX B}

\section{DAILY ACTIVITY REPORTS}


Demonstration of River Crossing Technology for Installation of Enviroumextal Horizontal Wells: AMH-6 and AMH-7 Installation Report CDM Federal Programs Corporation

May 5, 1993
Westinghouse Savannah River Company Subcontract No. AA46325P Task Order No. 10

THIS PAGE INTENTIONALLY LEFT BLANK 
Demonstration of River Crossing Technology for Installation of Eovironmental Horizontal Wells: AMH-6 and AMH-7 Installation Report CDM Federal Programs Corporation

May 5,1993
Westinghouse Savannah River Company Subcontract No. AA46325P

Task Order No. 10

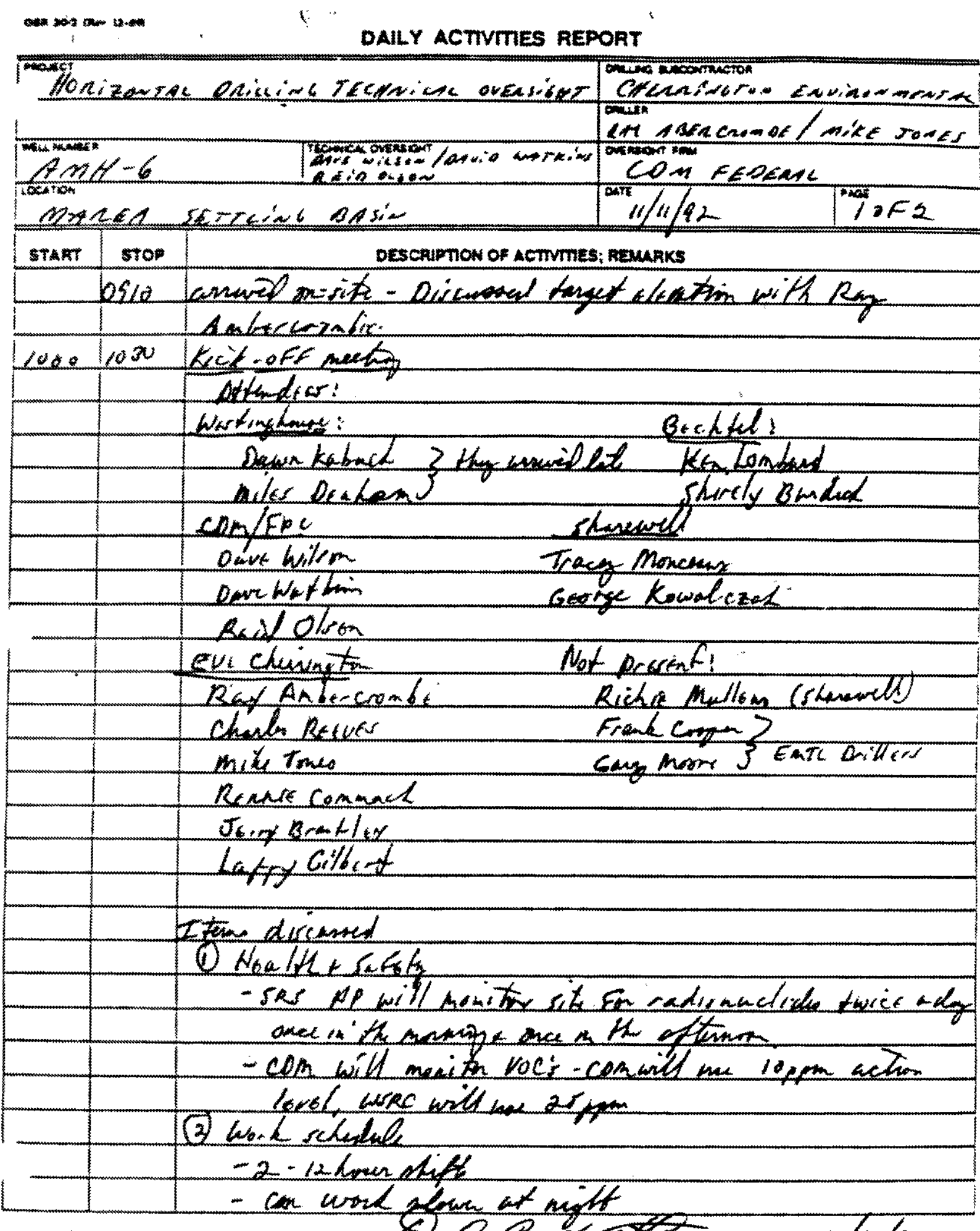

TECHNICAL OVERSIGHT SIGNATUAE Ela Q. DATE $11 / 11 / 12$ 
Demonstration of River Crossing Technology for Installation of Environmental Horizontal Wells: AMH-6 and AMH-7 Installation Report CDM Federal Programs Corporation May 5, 1993
Westinghouse Savannah River Company Subcontract No. AA46325P Task Order No. 10

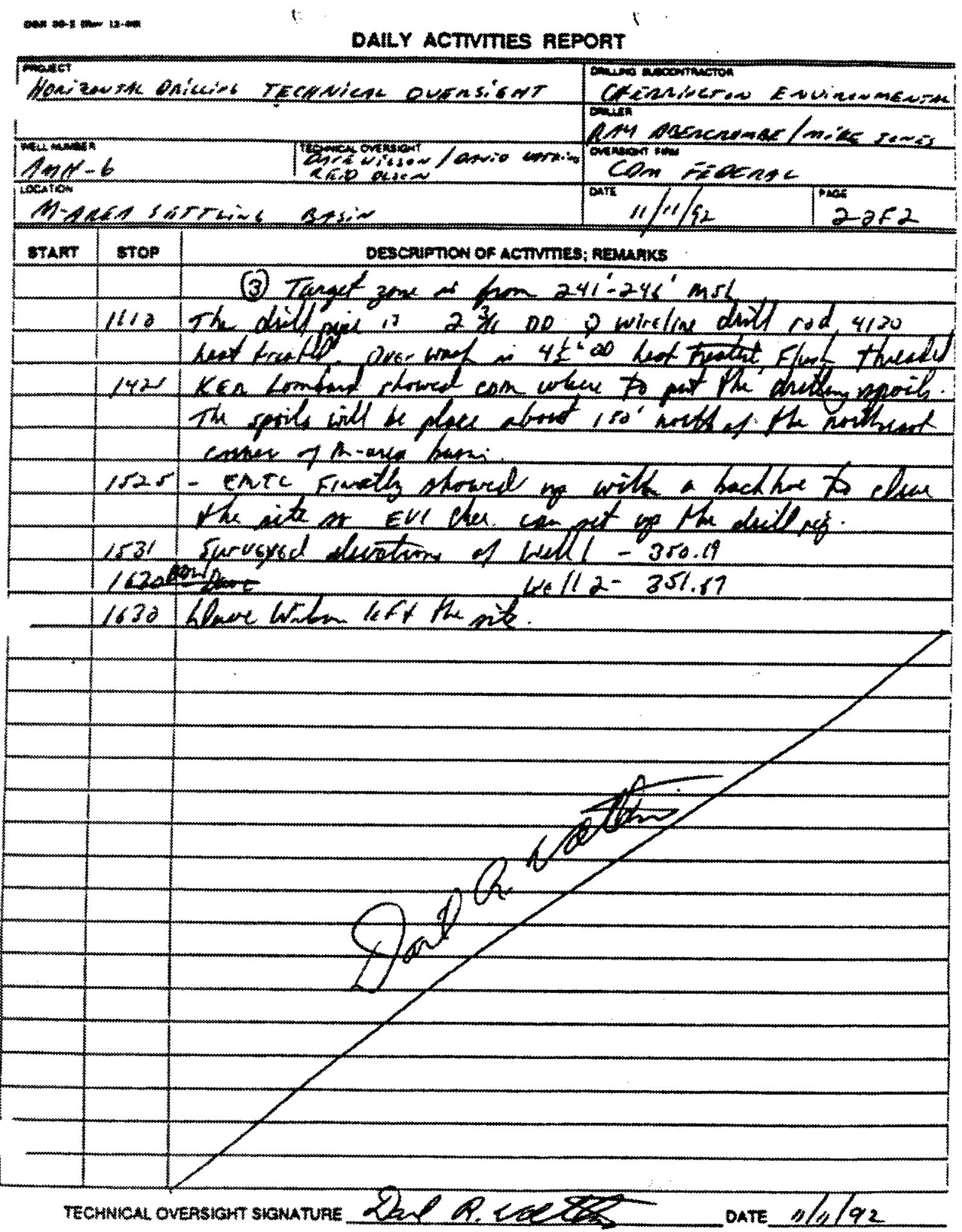


Demonstration of River Crossing Technology for Installation of Exvironmental Horizontal Wells: AMH -6 and AMH-7 Installation Report CDM Federal Programs Corporation May 5,1993
Westinghouse Savannah River Company Subcontract No. AA46325P Task Onder No. 10

2.

DALY ACTIVTES REPORT

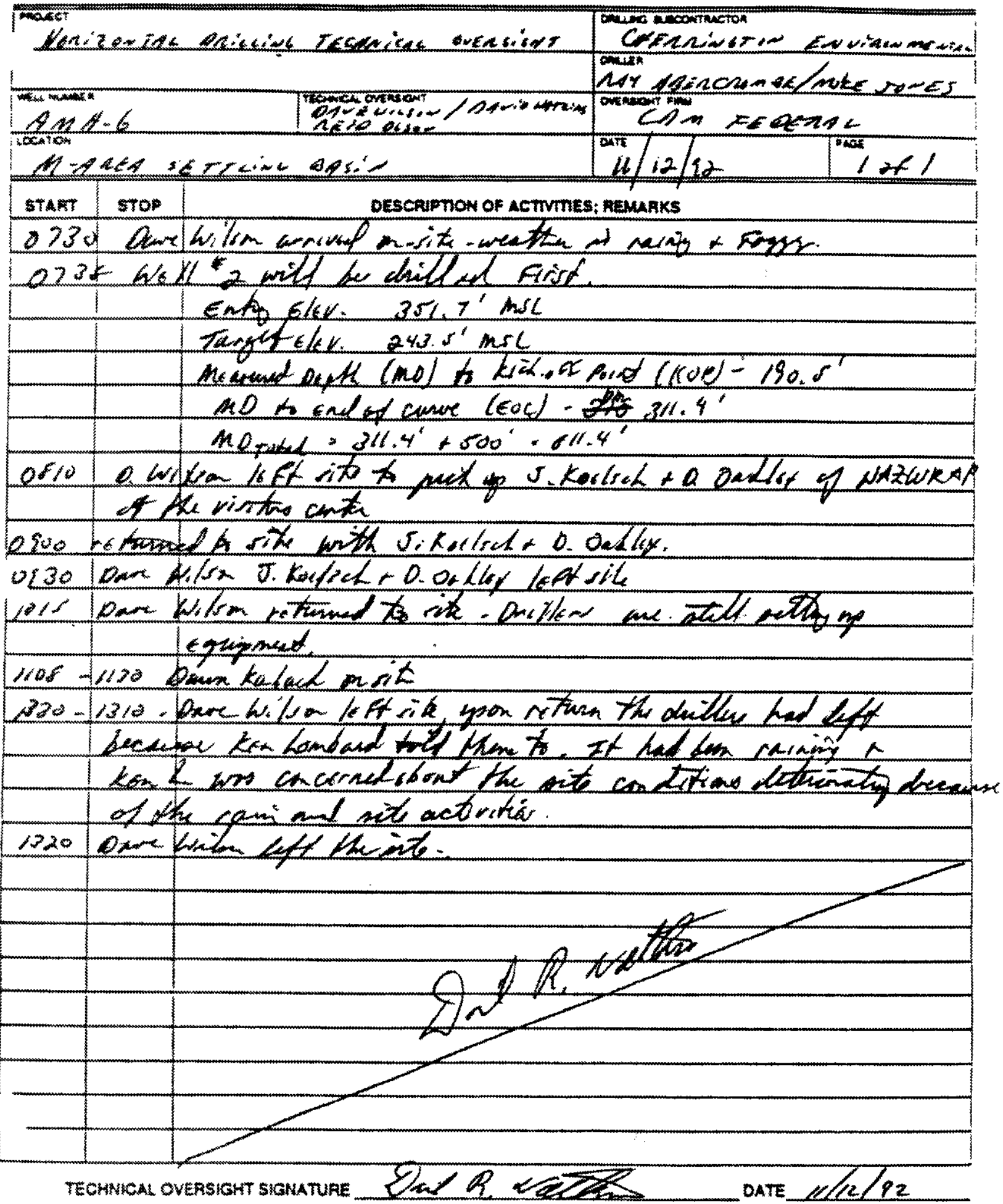


Dewacestration of River Crossing Technology for Installation of Westinghouse Savannah River Company Envirowmental Horizontal Wells: AMH-6 and AMH-7 Installation Report CDM Federal Programs Corporation

Subcontract No. AA46325P May 5,1993

Task Order No. 10

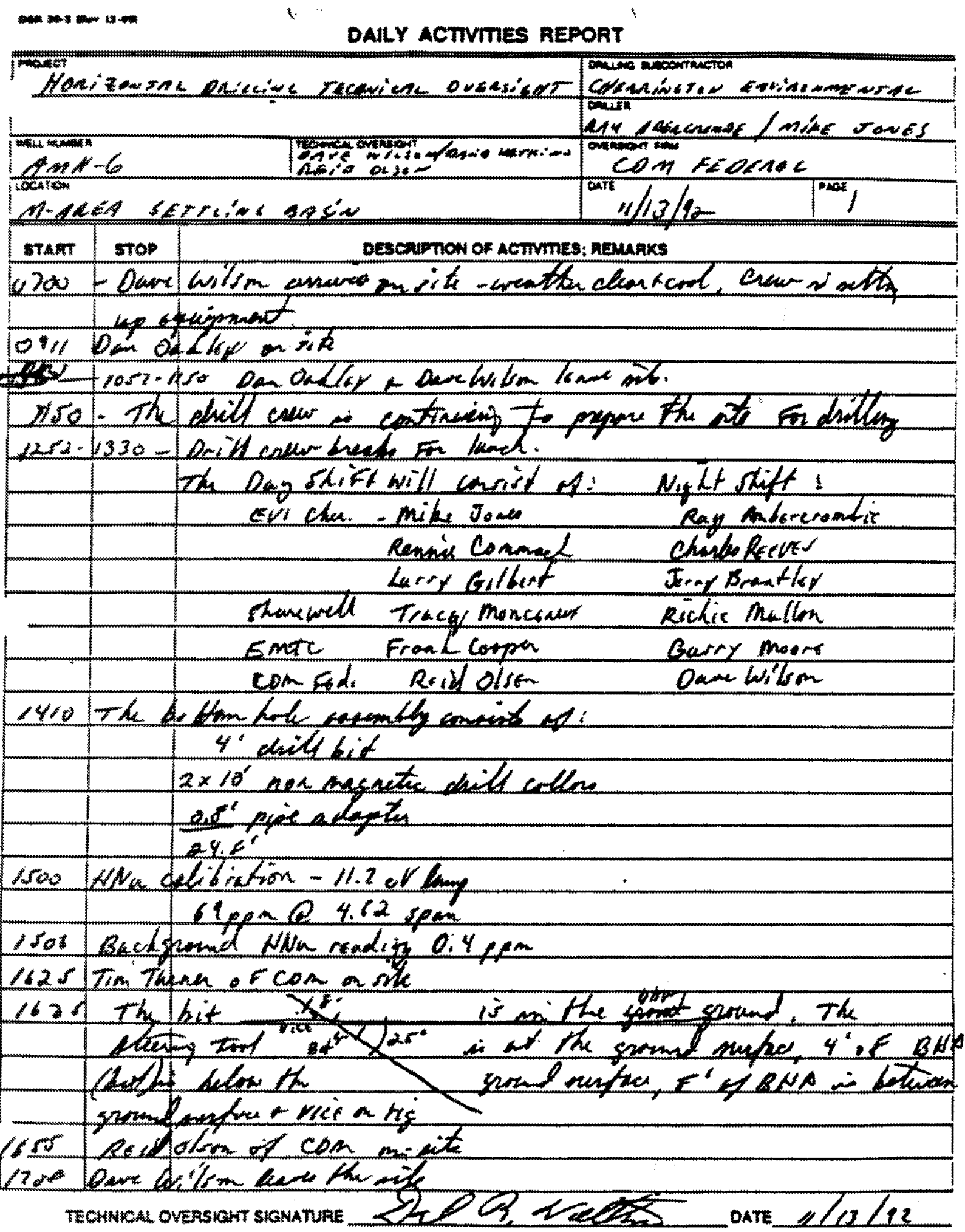

B-6 
Demonstration of River Crossing Technology for Installation of Environmental Horizontal Wells: AMH-6 and AMH - 7 Installation Report CDM Foderal Programs Corporation

May 5,1993
Westinghouse Savannah River Company Subcontract No. AA46325P Task Order No, 10

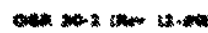

DALLY ACTVITES REPOAT

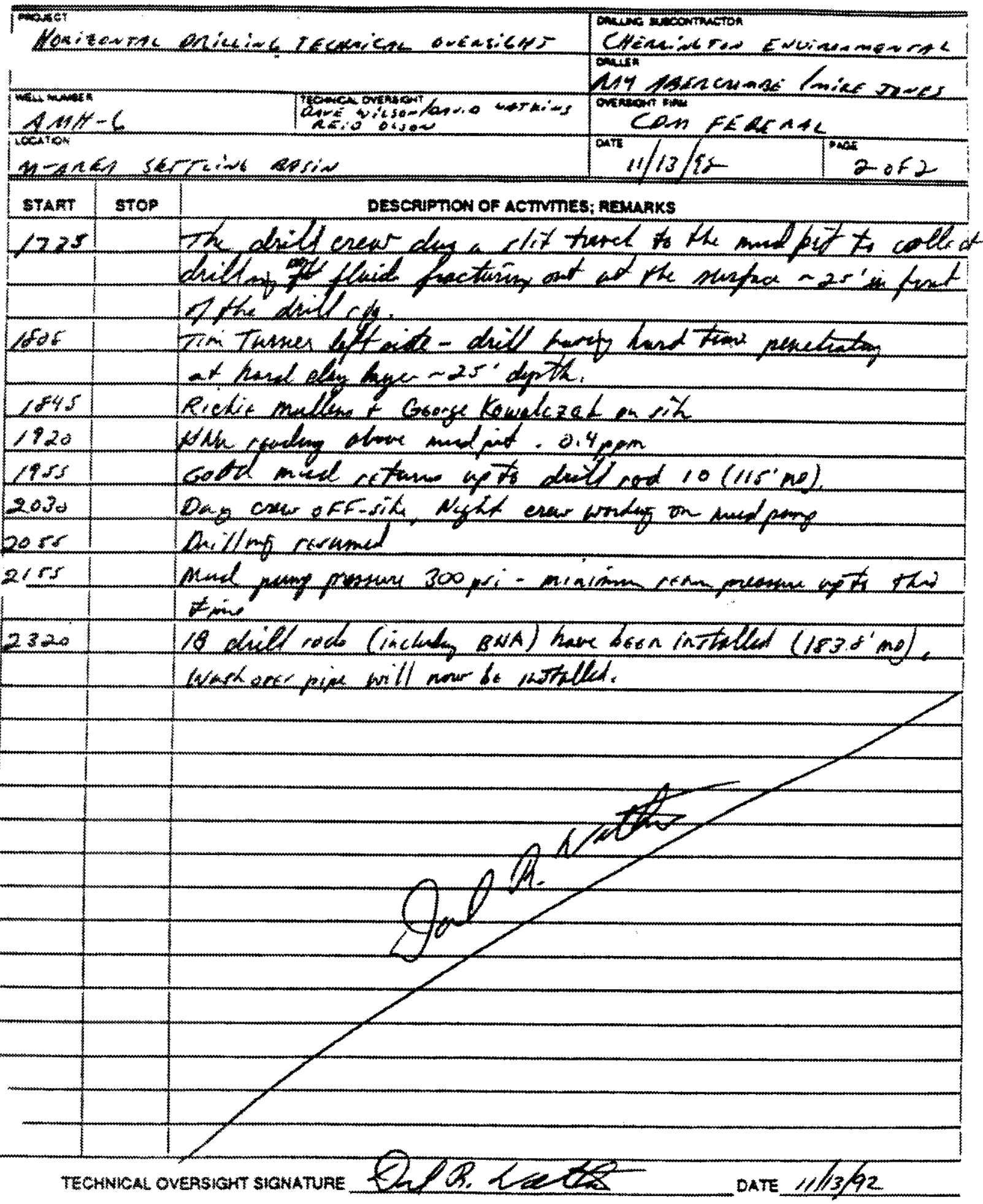


Demonstration of River Crossing Technology for Installation of Enviromanental Horizontal Wells: AMH-6 and AMH-7 Installation Report CDM Federal Programs Corporation

May \$, 1993
Westinghouse Savamnah River Company Subcontract No. AA46325P Task Order No. 10

\section{-1.}

DALY ACTIVIES REPORT

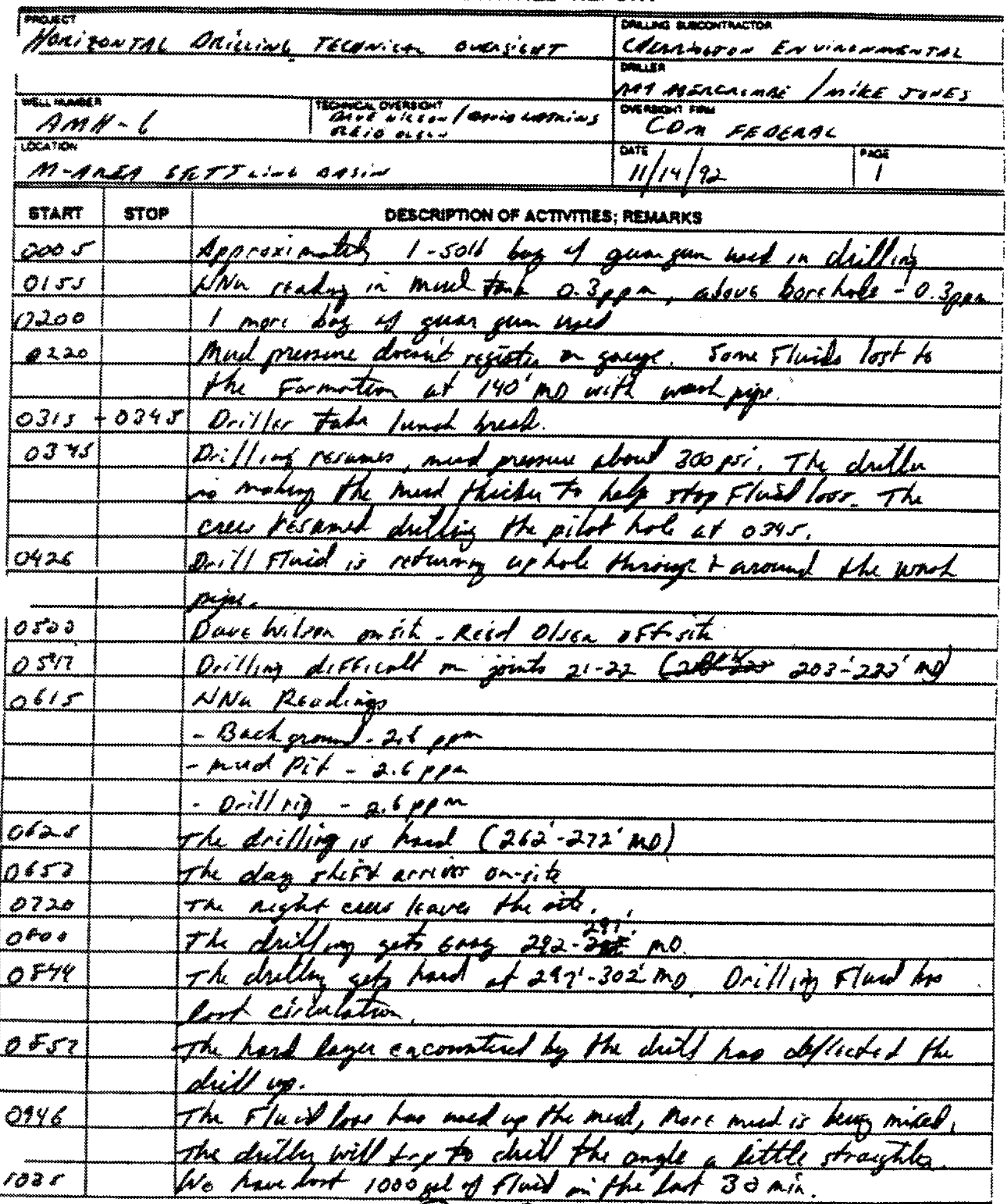

TrCHNICAL OVEASGOH SIGNATUAE EDQ DATE I/W/92

B.8 
Demonstration of River Crossing Technology for Installation of Environmental Horizontal Wells: AMH-6 and AMH-7 Installation Report CDM Federal Programs Corporation May 5, 1993
Westinghouse Savannah River Company Subcontract No. AA46325P

Task Order No. 10

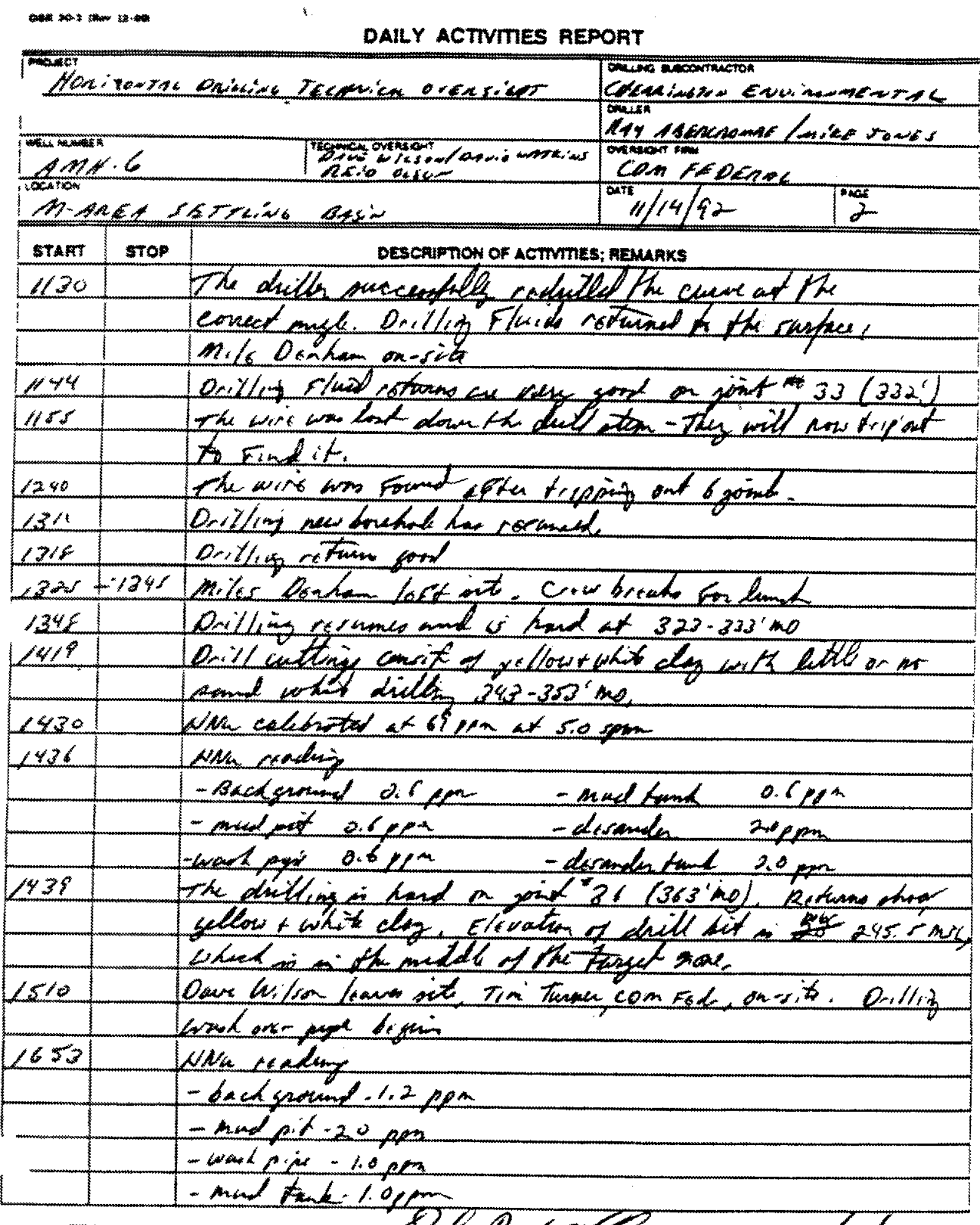

TECHNICAL OVERSHOHT SIGNATURE Qd a DATE $10 / 14 / 92$ 
Demonstration of River Crossing Technology for Installation of Environmental Horizontal Wells: AMH-6 and AMH-7 Installation Report CDM Federal Programs Corporation

May 5, 1993
Westinghouse Savannah River Company Subcontract No. AA46325P

Task Onder No. 10

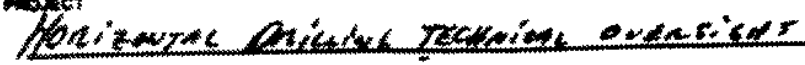

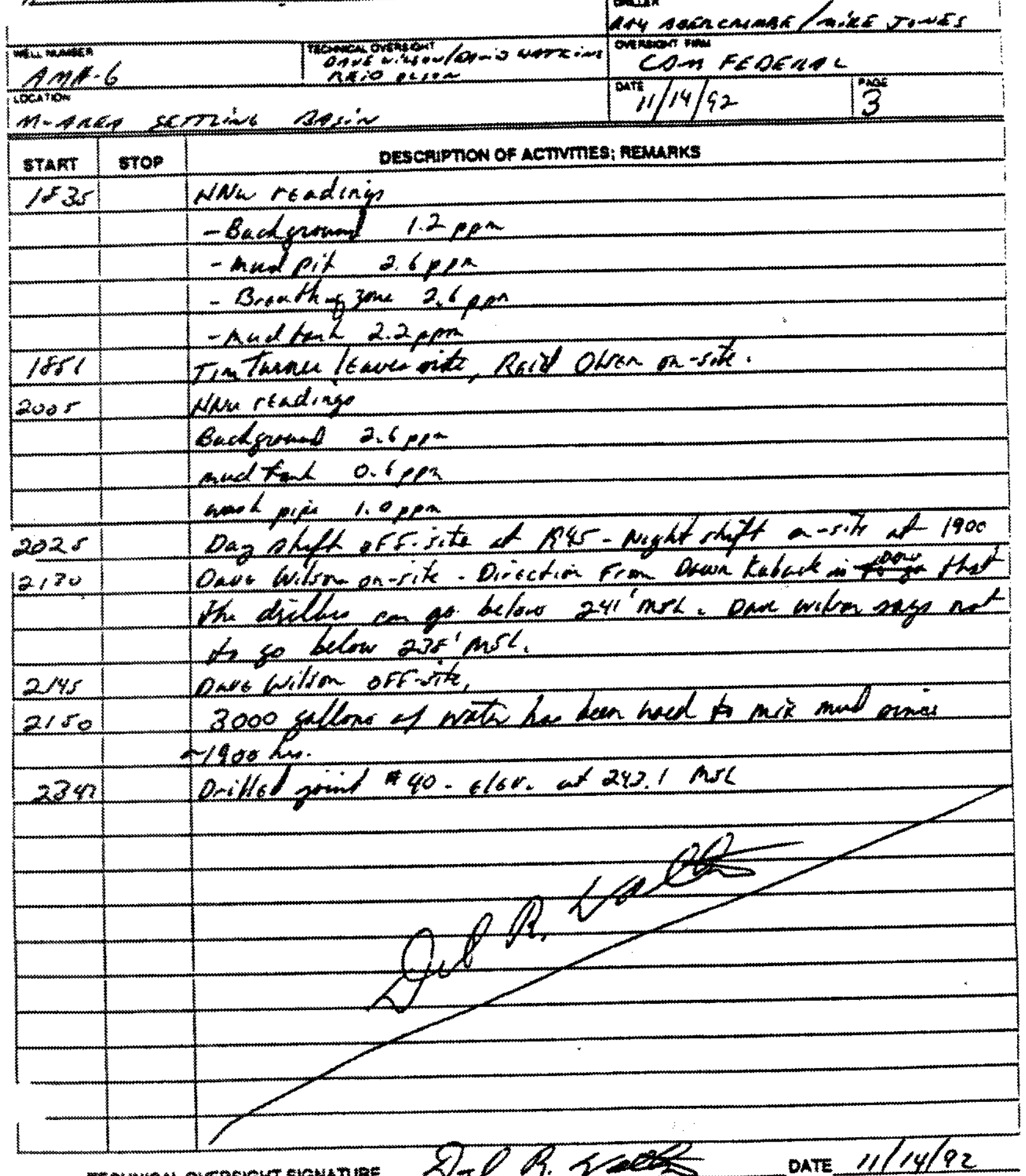

B-10 
Demonstration of River Crossing Technology for Installation of Westinghouse Savannah River Company Exvironmental Horizontal Wells: AMH-6 and AMH-7 Installation Report

Subcontract No. AA46325P

CDM Federal Programs Corporation

Task Order No, 10

May 5,1993

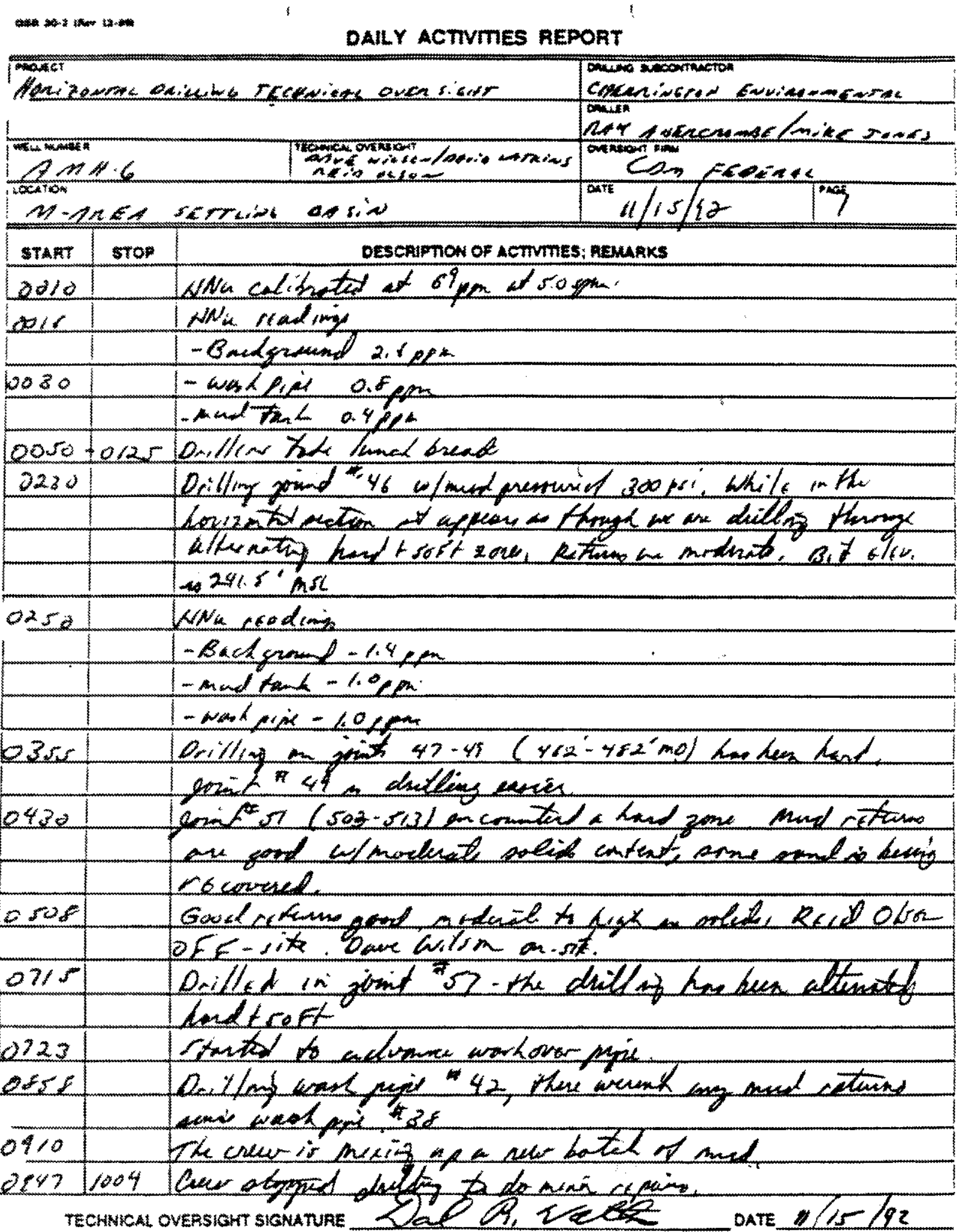


Demonstration of River Crossing Technology for Installation of Environmental Horizontal Wells: AMH-6 and AMH-7 Installation Report CDM Federal Programs Corporation

May 5,1993
Westinghouse Savannah River Company Subcontract No. AA46325P Task Order No. 10

4010

DALLY ACTIVMES REPORT

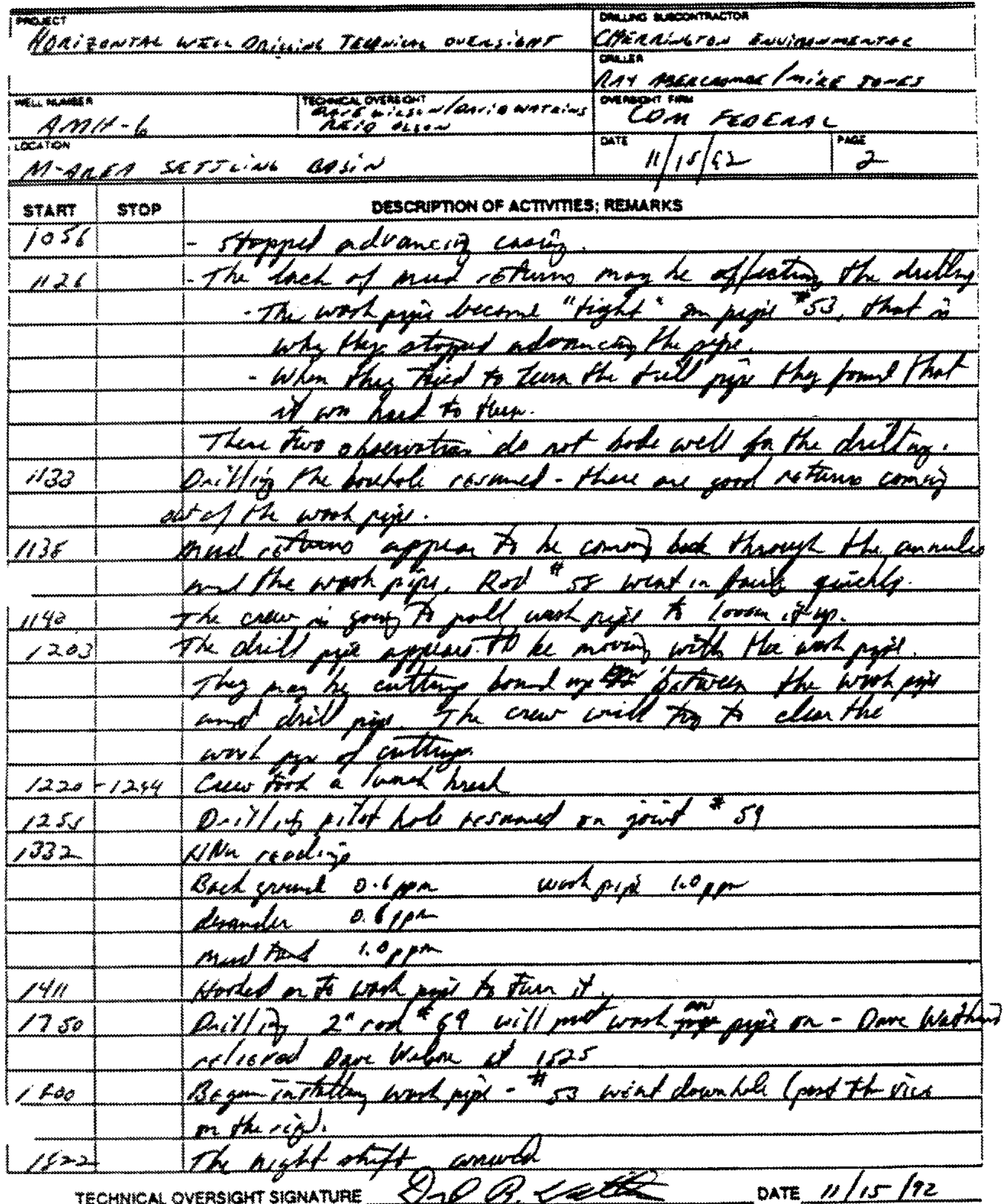


Demonstration of River Crossing Techrology for Installation of Environmental Horizontal Wells: AMH-6 and AMH-7 Installation Repon CDM Federal Programs Corporation May 5, 1993
Westinghouse Savannah River Company Subcontract No. AA46325P

Task Order No. 10

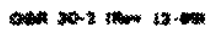

\section{DALY ACTIVTIES REPORT}

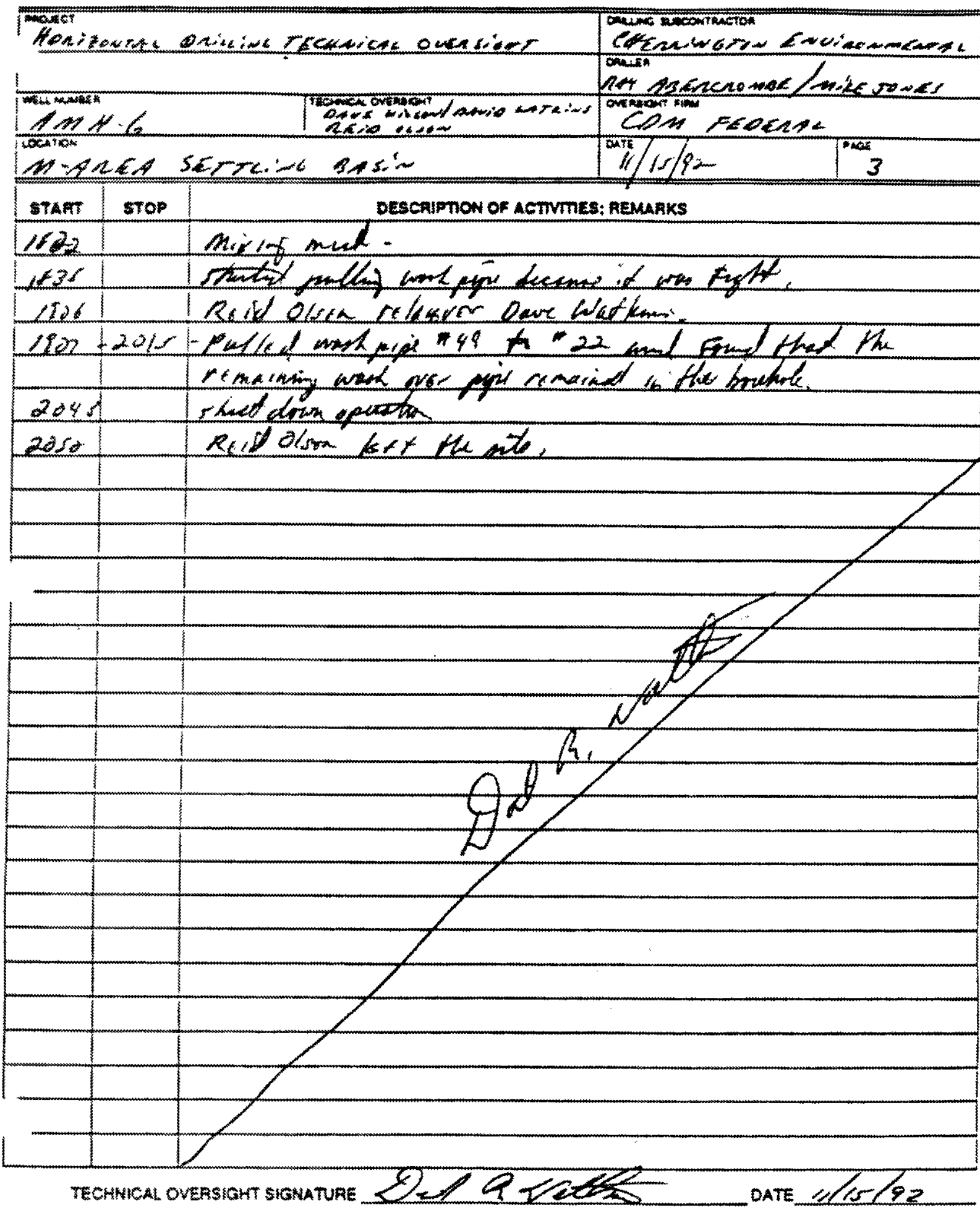


Demonstration of River Crossing Technology for Installation of Environmental Horizontal Wells: AMH-6 and AMH-7 Installation Repor CDM Federal Programs Corporation

May 5,1993
Westinghouse Savannah River Company Subcontract No. AA46325P

Task Order №. 10

-

DAILY ACTIVTIES REPORT

Manis

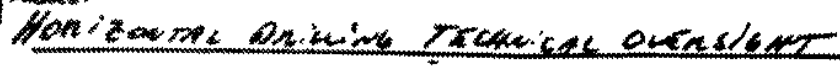

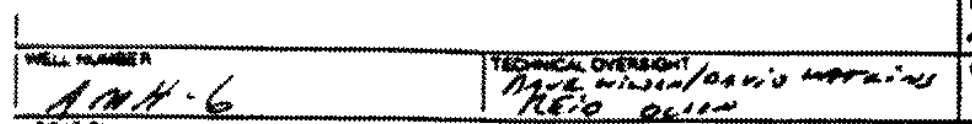

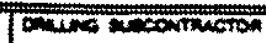

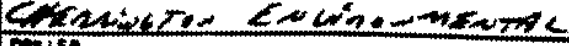
bisth

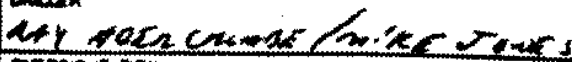

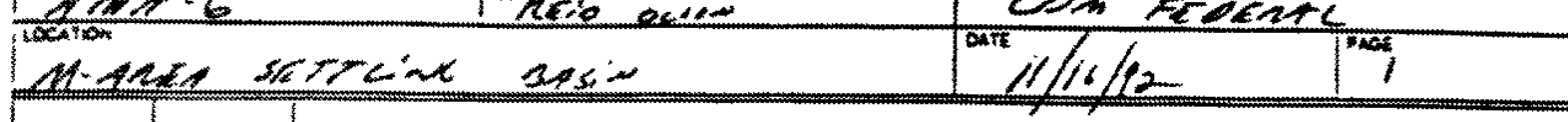

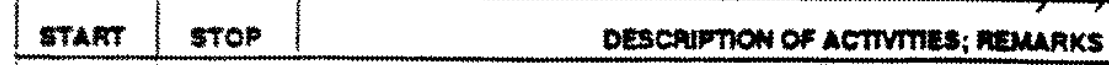

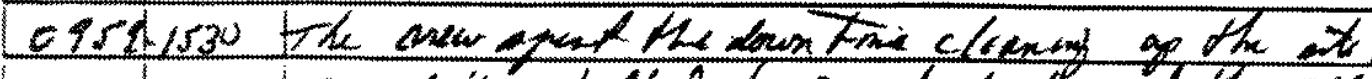

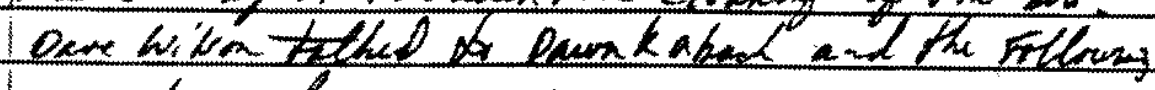
lax decenel.

-

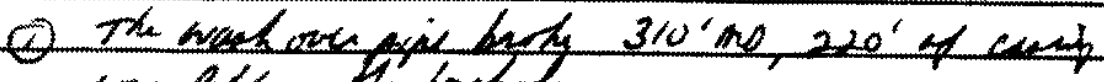
ans futt in the buarle.

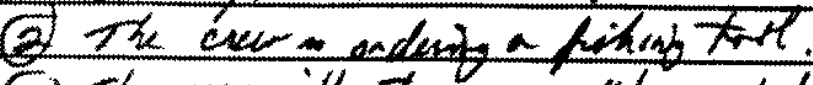

(3) The cnew with the 24 and day

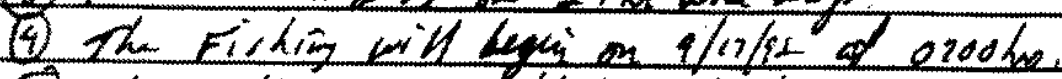

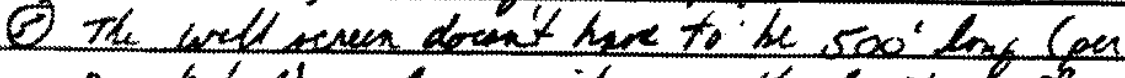

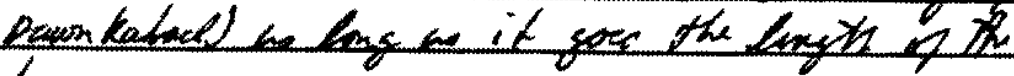

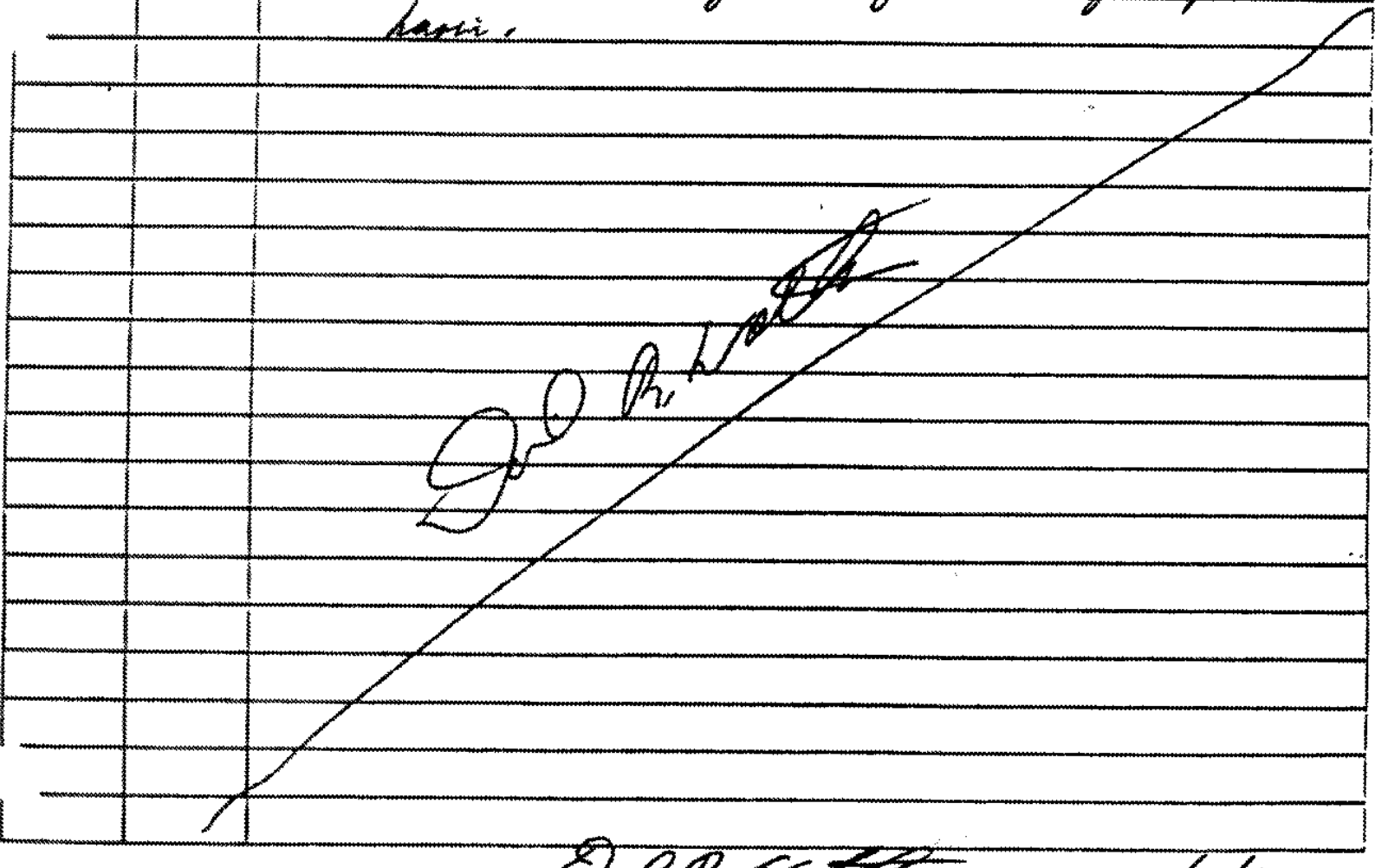

TECHWCA OVERSIOHT SIGNATURE

2003 DATE $1 / 1 / 62$ 
Demonstration of River Crossing Technology for Installation of Environmental Horizontal Wells: AMH-6 and AMH-7 Installation Report CDM Federal Programs Corporation May 5,1993
Westinghouse Savannah River Company Subcontract No. AA46325P Task Order No. 10

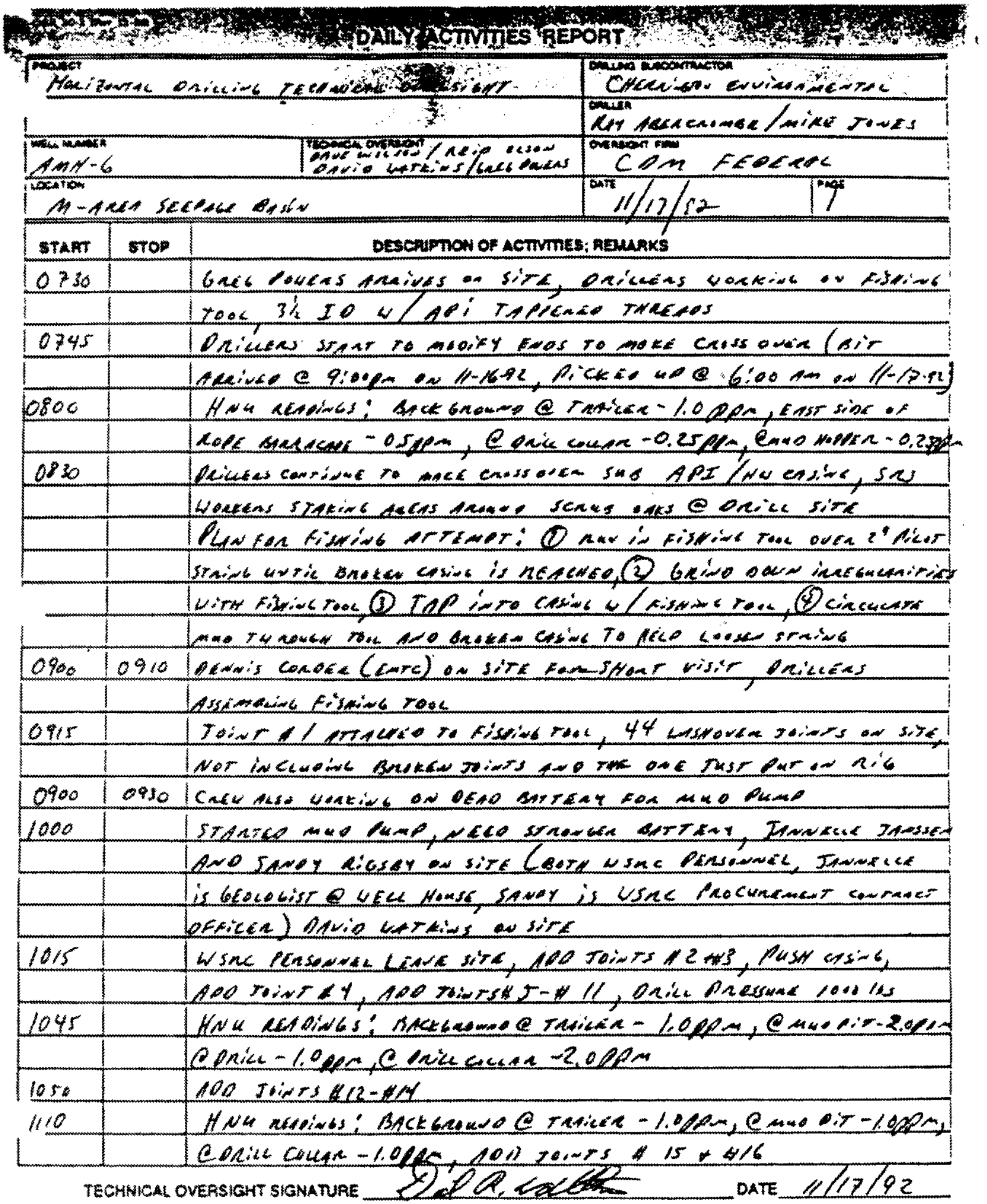


Demonstration of River Crossing Technology for Installation of Environmental Horizontal Wells: AMH-6 and AMH-7 Installation Repor COM Federal Programs Corporation

May 5,1993
Westinghouse Savannah River Company

Subcontract No. AA46325P

Task Order No. 10

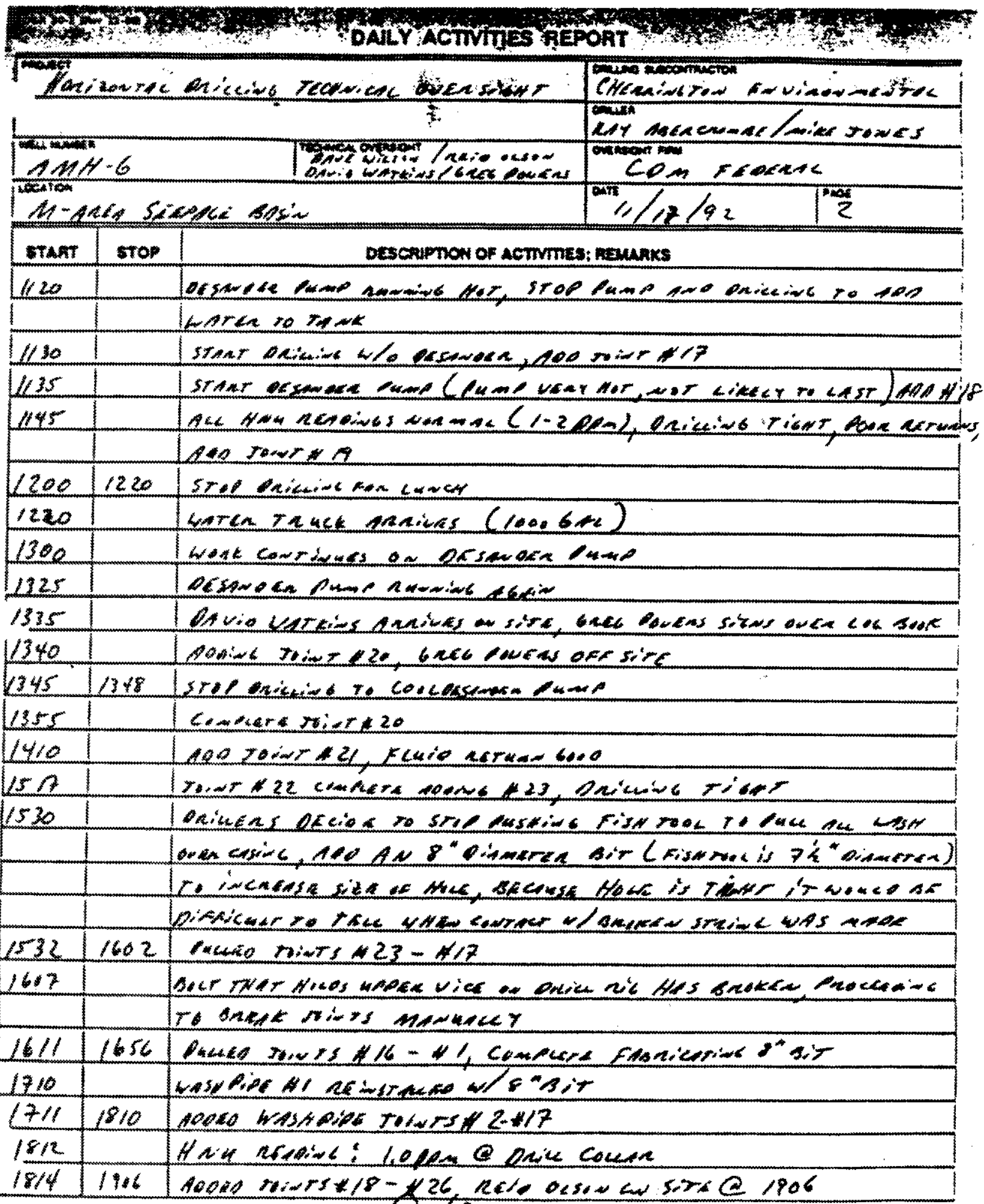

TECHNICA OVERSIGHT SIGNATURE Sabareze DATE $/ 1 / 13 / 42$ 
Demonstration of River Crossing Technology for Installation of Enviroamental Horizontal Wells: AMH-6 and AMH-7 Installation Report CDM Federal Programs Corporation

Westinghouse Savannah River Company May 5, 1993

Subcontract No. AA46325P

Task Order No. 10

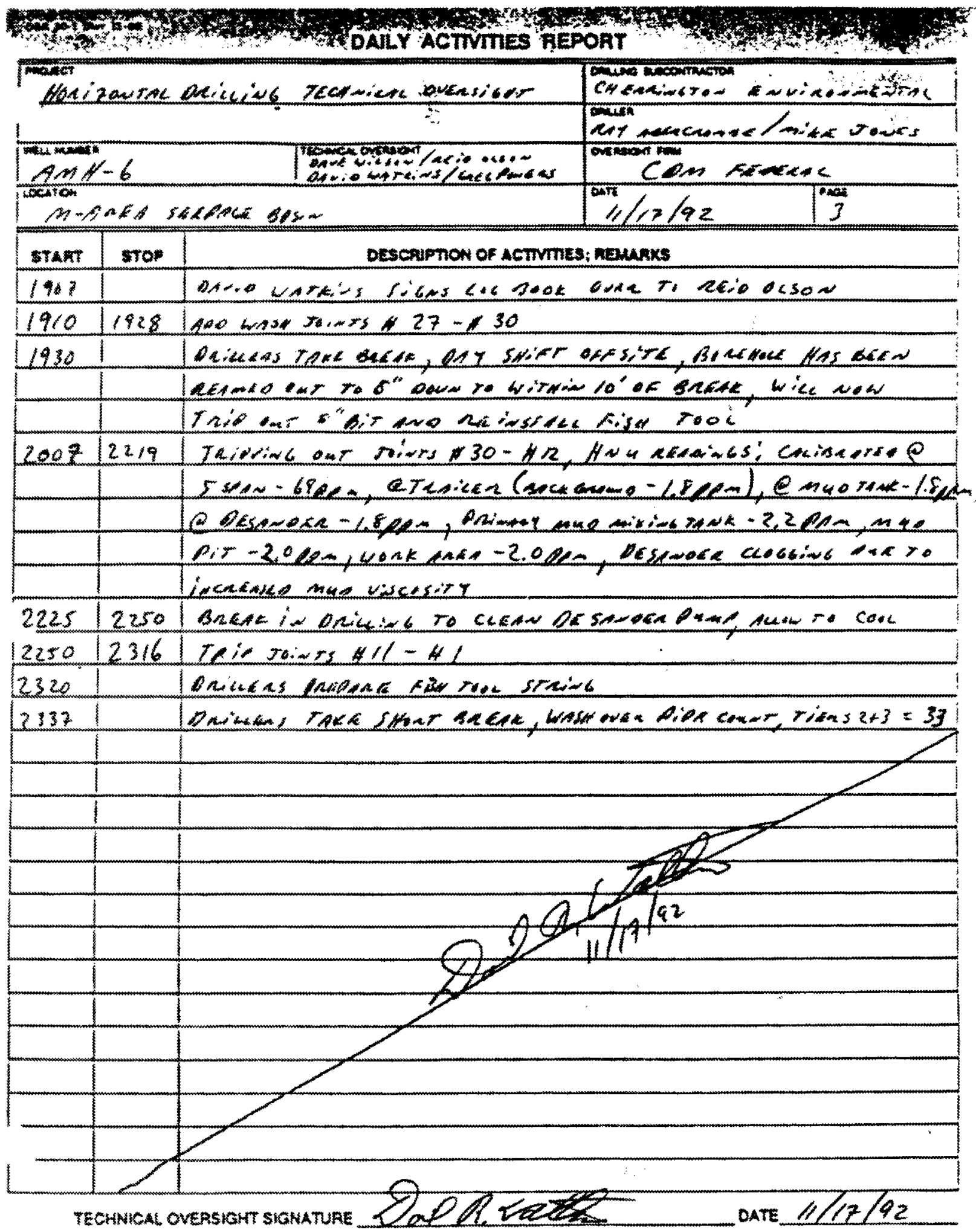


Demonstration of River Crossing Technology for Installation of West Environmental Horizontal Wells: AMH-6 and AMH-7 Installation Report CDM Federal Programs Corporation May 5, 1993

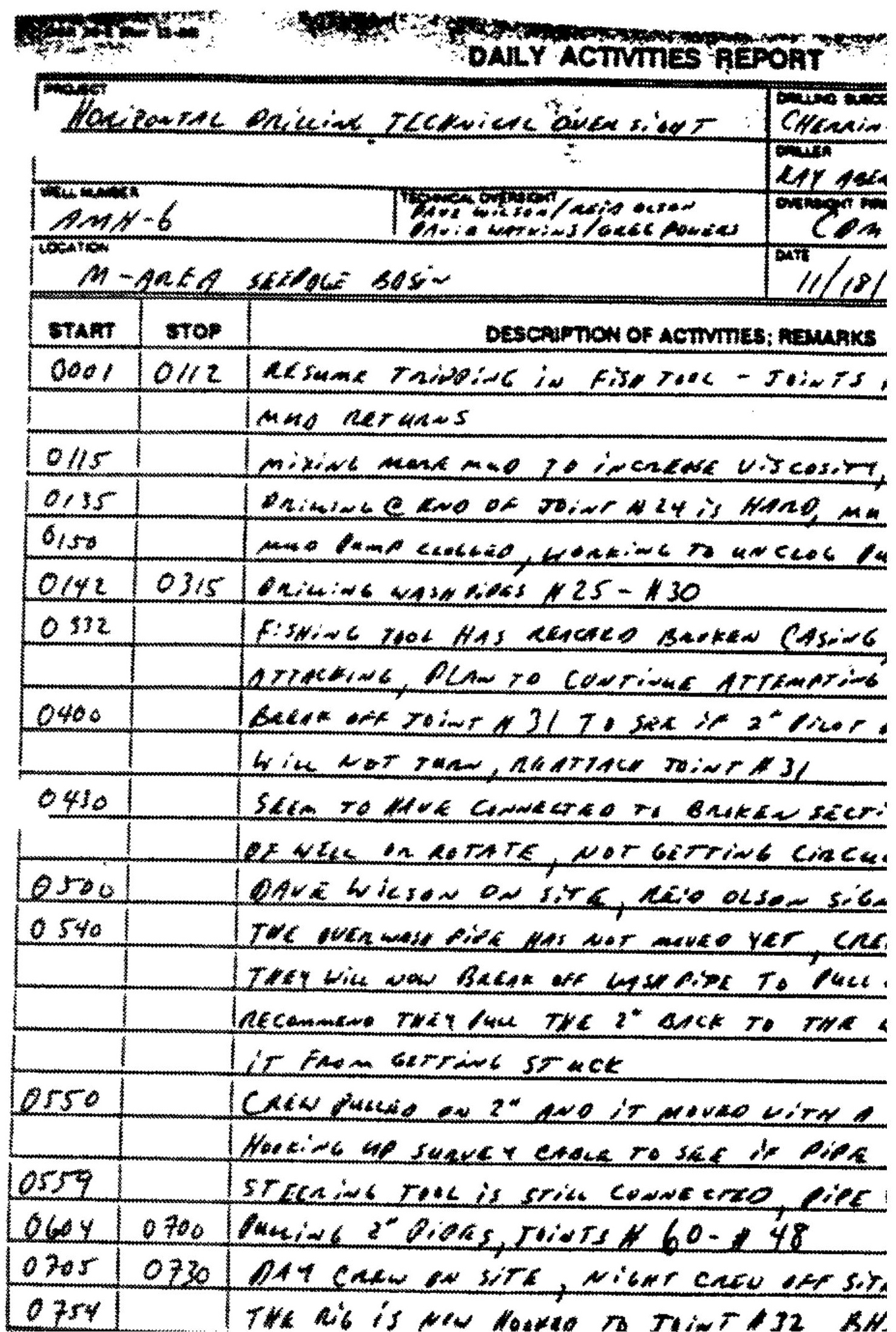


Demonstration of River Crossing Technology for Installation of West Environmental Horizontal Wells: AMH-6 and AMH-7 Installation Report CDM Federal Programs Corporation May 5, 1993

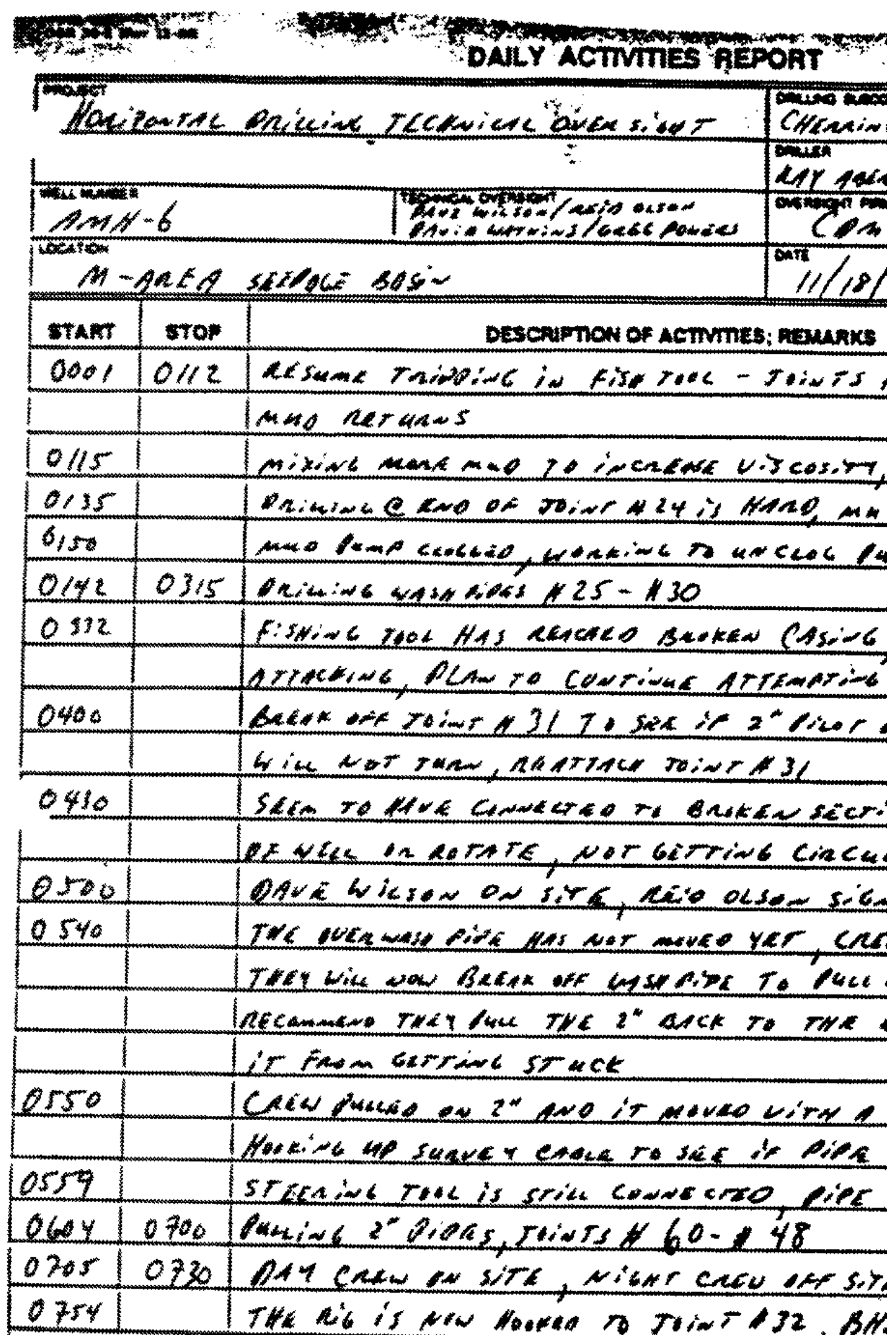


Demonstration of River Crossing Technology for Installation of Eavironmental Horizontal Wells: AMH-6 and AMH-7 Installation Report CDM Federal Programs Corporation May 5, 1993
Westinghouse Savannah River Company Subcontract No. AA4632sP Task Order No. 10

\begin{tabular}{|c|c|c|}
\hline \multicolumn{2}{|c|}{ Hoxizonect } & 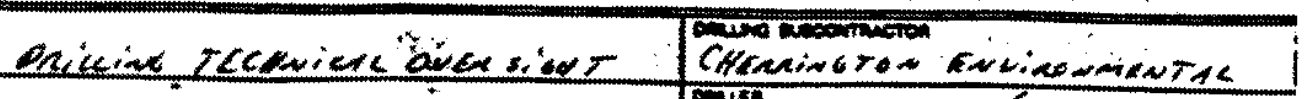 \\
\hline \multicolumn{3}{|c|}{$\frac{1}{10}$} \\
\hline \multicolumn{2}{|c|}{ 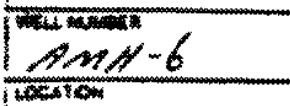 } & कom teenete \\
\hline \multicolumn{2}{|c|}{$A-A A E A$} & $11 / 18 / 92$ \\
\hline \multirow{3}{*}{ trant } & sto: & Descrupnow of Acmmes; newarks \\
\hline & \multirow[t]{2}{*}{$0 / 12$} & 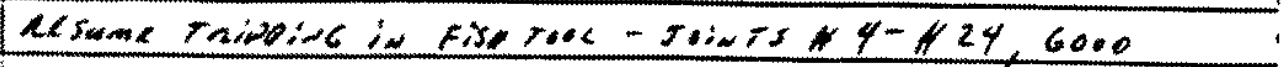 \\
\hline & & Mno nerants \\
\hline \multicolumn{2}{|l|}{$0 / 15$} & 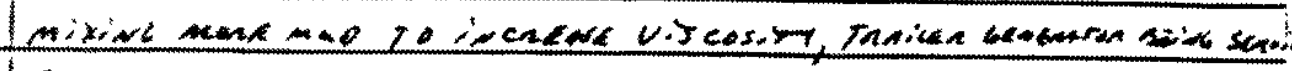 \\
\hline \multicolumn{2}{|l|}{0.35} & 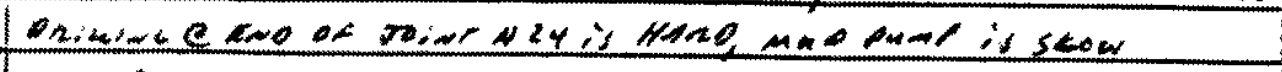 \\
\hline \multicolumn{2}{|l|}{$6 / 58$} & 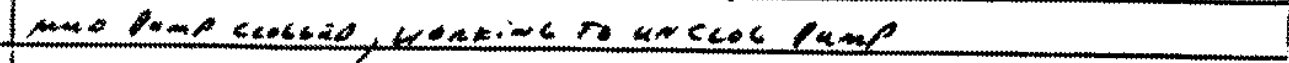 \\
\hline \multirow{3}{*}{$\frac{0142}{0132}$} & 0315 & 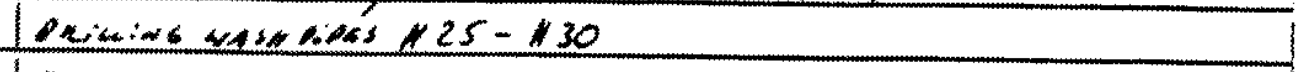 \\
\hline & & 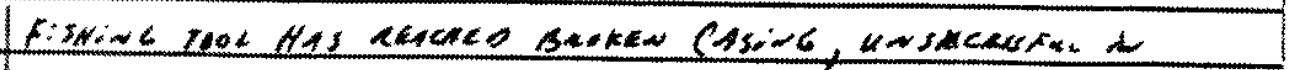 \\
\hline & & 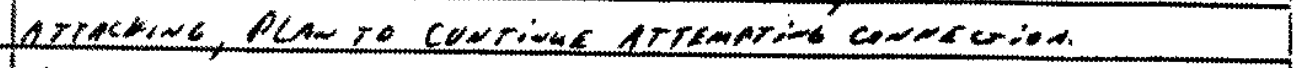 \\
\hline \multirow[t]{2}{*}{040} & & 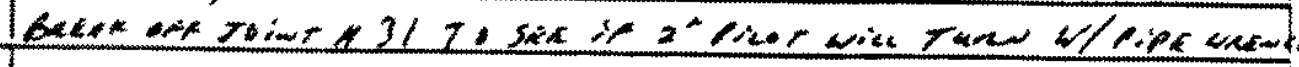 \\
\hline & & 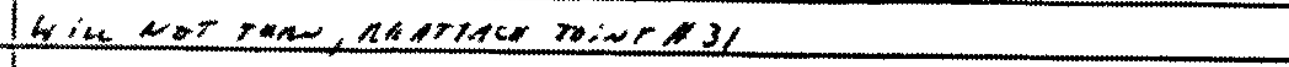 \\
\hline \multirow[t]{2}{*}{04,0} & & 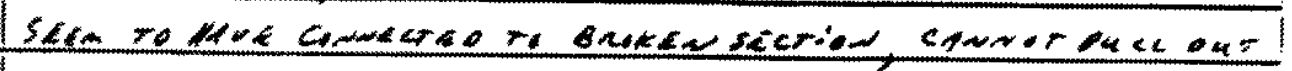 \\
\hline & & 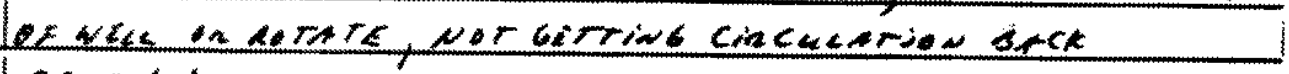 \\
\hline \multicolumn{2}{|l|}{$0 \pm 01$} & \multirow{2}{*}{ 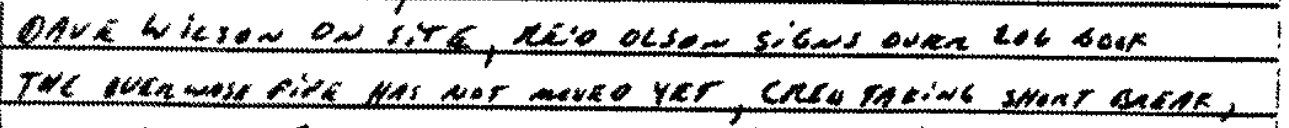 } \\
\hline \multirow[t]{4}{*}{0540} & & \\
\hline & & 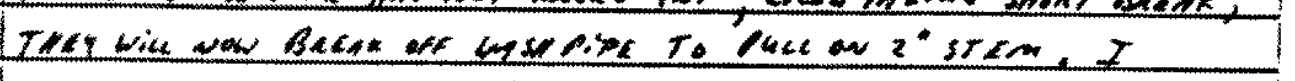 \\
\hline & & 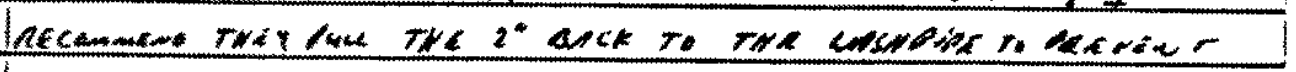 \\
\hline & & 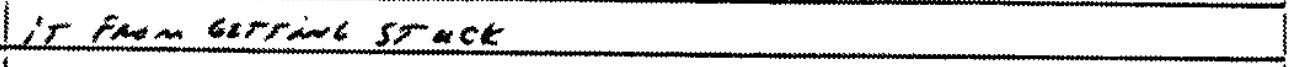 \\
\hline 0550 & & 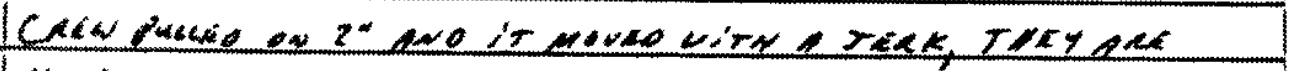 \\
\hline & & 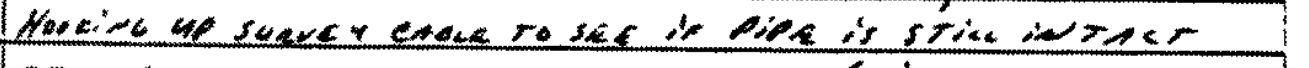 \\
\hline 0559 & & 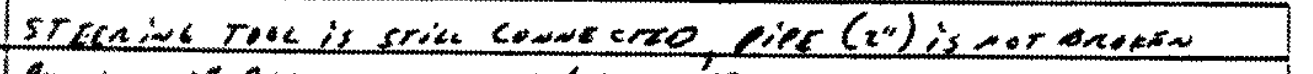 \\
\hline $060 y$ & 0700 & 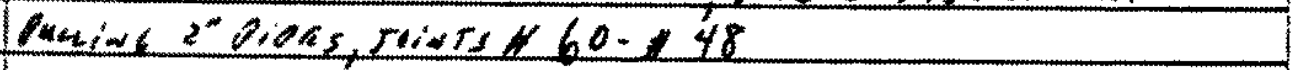 \\
\hline 0205 & 0230 & 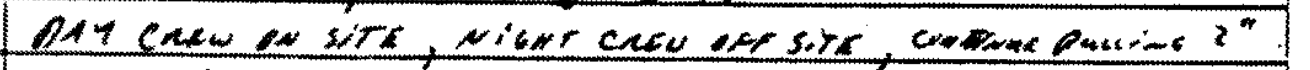 \\
\hline $0+24$ & & 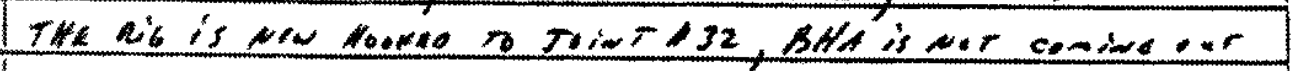 \\
\hline 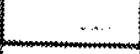 & & of Ite ovan \\
\hline 0826 & & 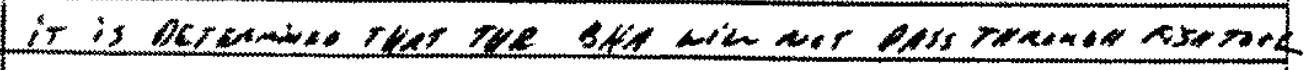 \\
\hline 0930 & & 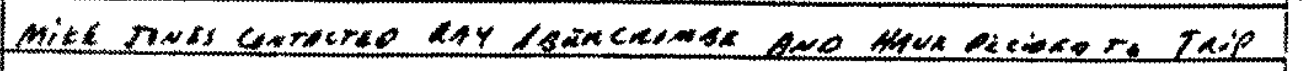 \\
\hline & & 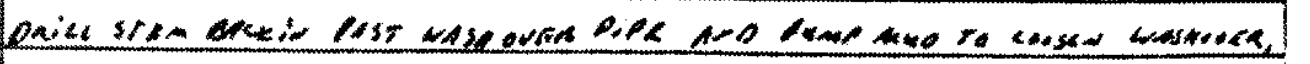 \\
\hline & & 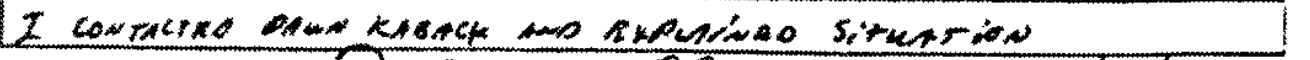 \\
\hline
\end{tabular}

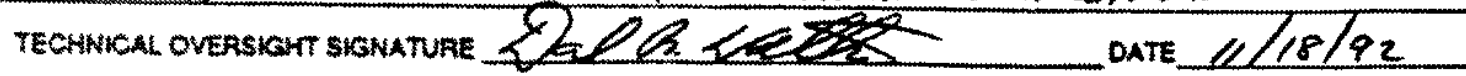
B-18 
Demonstation of River Crossing Technology for Installation of Envirommental Horizontal Wells: AMH -6 and AMH-7 Installation Report CDM Federal Programs Corporation

May 5,1993
Westinghouse Savannab River Company Subcontract No. AA46325P Task Order No. 10

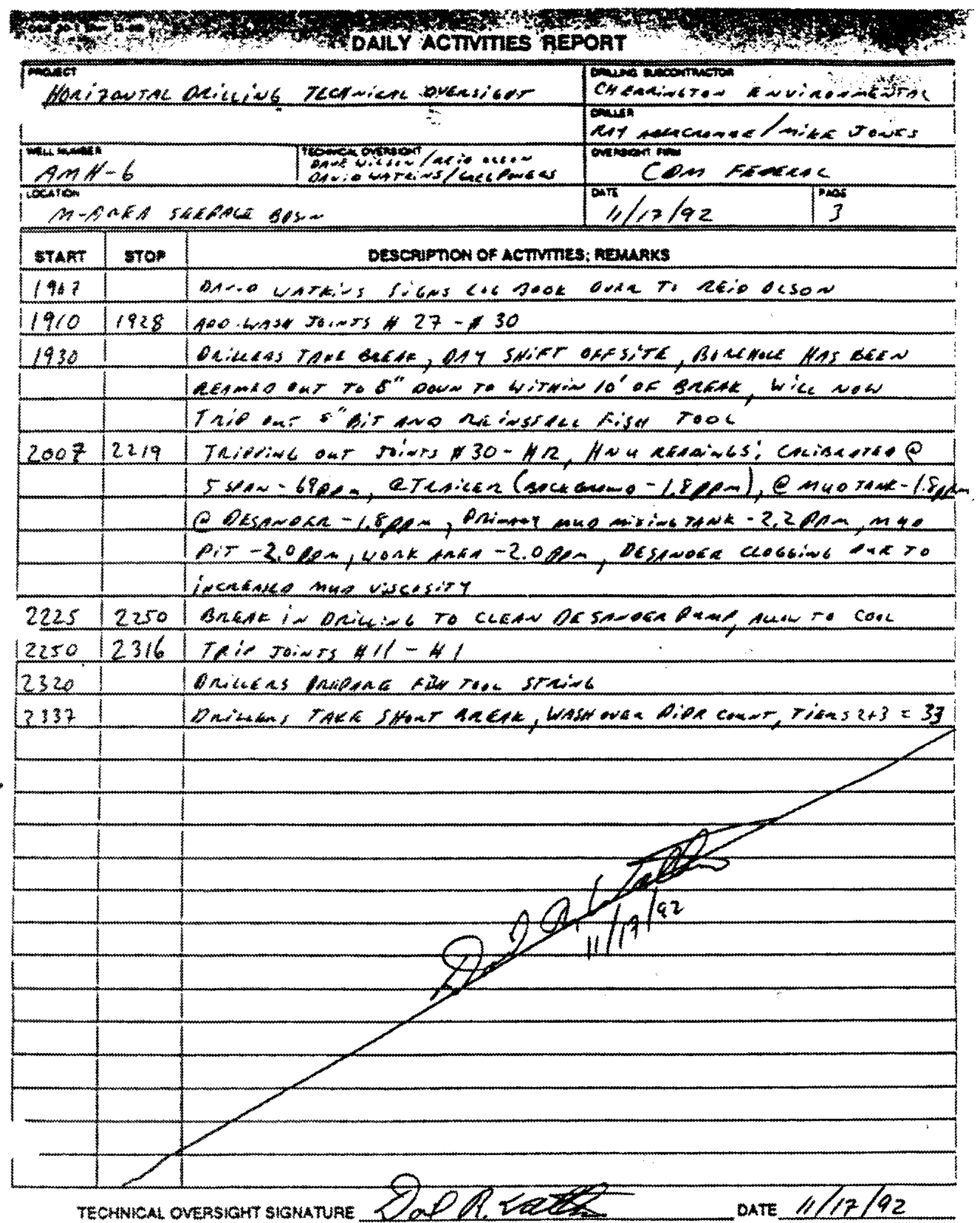


Demonstration of River Crossing Technology for Installation of Westinghouse Savannah River Company Environmental Horizontal Wells: AMH-6 and AMH-7 Installation Report CDM Federal Programs Corporation

Subcontract No. AA46325P

May 5,1993

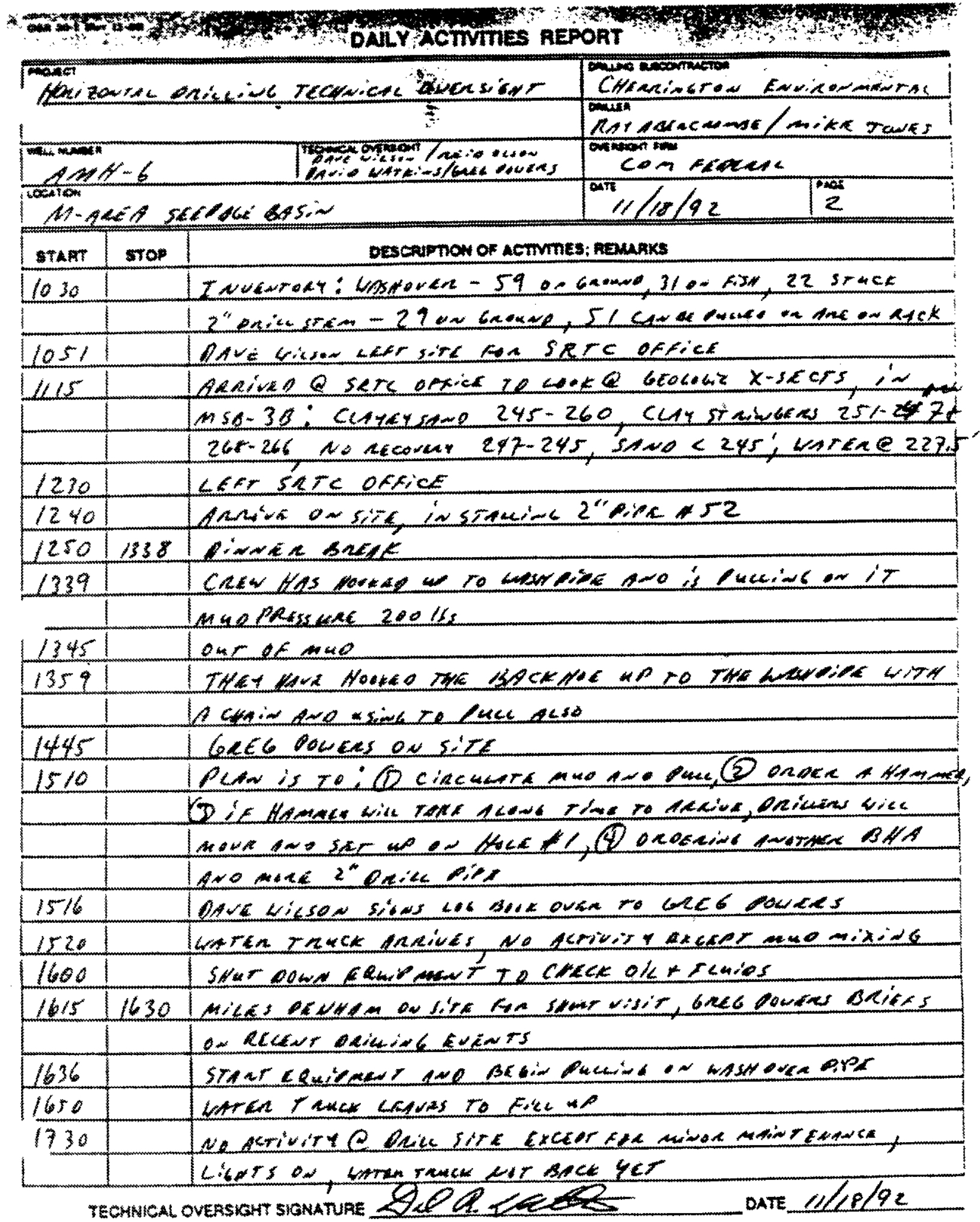


Dewnosstration of River Crossing Technology for Installation of Environmental Horizontal Wells: AMH-6 and AMH-7 Installation Report CDM Federal Programs Corporation May 5, 1993
Westinghouse Savannah River Company Subcontract No. AA46325P Task Order No. 10

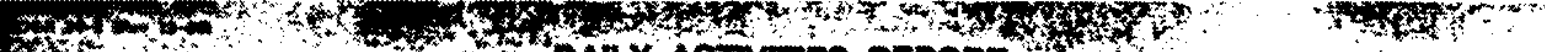 DALLY ACTVMTES REPORT}

\begin{tabular}{|c|c|c|c|}
\hline Hani & ras & 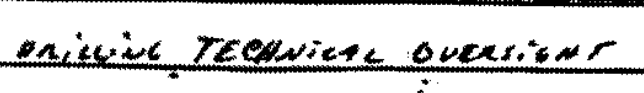 & CHFeximeran EN \\
\hline & & & 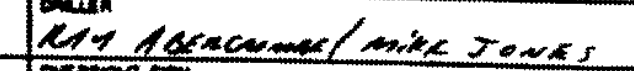 \\
\hline $\mathrm{Ams}$ & & 10 & Con revens \\
\hline$m-1$ & & SEEEAG SAsin & in/1/8/92 \\
\hline stant & stop & Desschup now of ACTMTM & ss:memukns \\
\hline 1735 & & untele raecex dexives or sirfe & \\
\hline 1745 & & 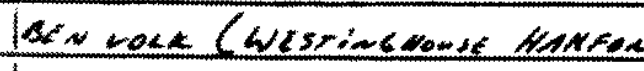 & - Lon siren assea \\
\hline 1140 & & wient snier on site & \\
\hline 1850 & & 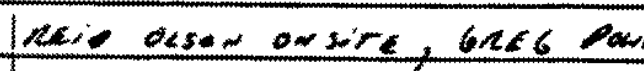 & eas siows ouen 206 sook \\
\hline 1900 & & 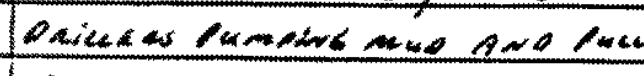 & 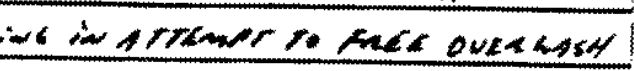 \\
\hline 1910 & & Denriak mue acrunan, mue la & 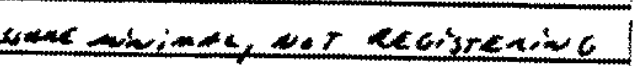 \\
\hline 2100 & & Sew vene oef sire, bew enty & 4 erranesree is con feocum \\
\hline & & Doinc Nemizentede Dnikeine a & ensigorr wouk C Manrond. \\
\hline & & 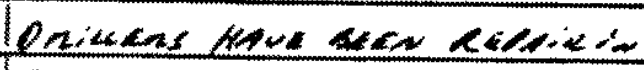 & 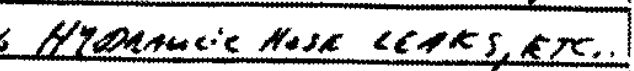 \\
\hline 2265 & & 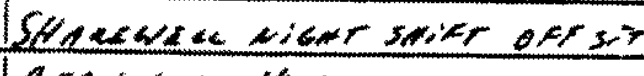 & C, Drimens stike condiog of \\
\hline & & 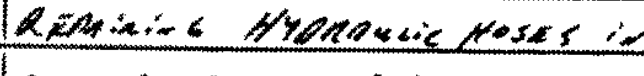 & THe coutan sox an nis, \\
\hline 240 & & 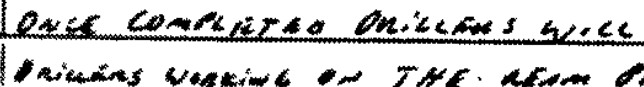 & 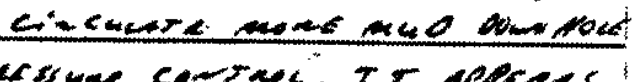 \\
\hline & & Ther The Desssune comren wine & 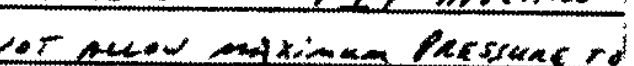 \\
\hline & & Ex atcivinero, IT is somerow a & $\therefore$ RCGmures \\
\hline 2250 & & nebuentom on cowrad davice & eEmoued DECTuse ir ans \\
\hline 310 & & 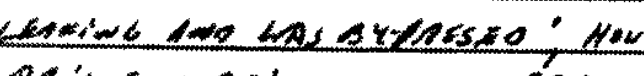 & 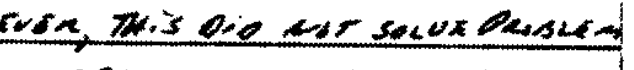 \\
\hline 310 & & 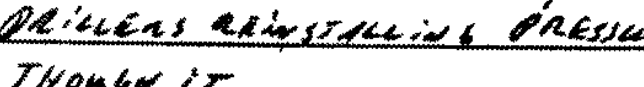 & 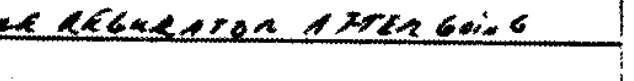 \\
\hline 51 & & 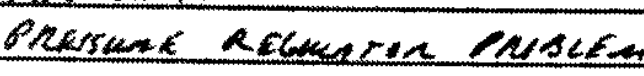 & Socver \\
\hline & & & \\
\hline & & & \\
\hline & & & \\
\hline & & & \\
\hline & & & \\
\hline & & & \\
\hline
\end{tabular}


Demonstration of River Crossing Technology for Installation of Environmental Horizontal Wells: AMH-6 and AMH-7 Installation Repon CDM Federal Programs Corporation

May 5,1993
Westinghouse Savannah River Company Subcontract No. AA46325P

Task Order No. 10

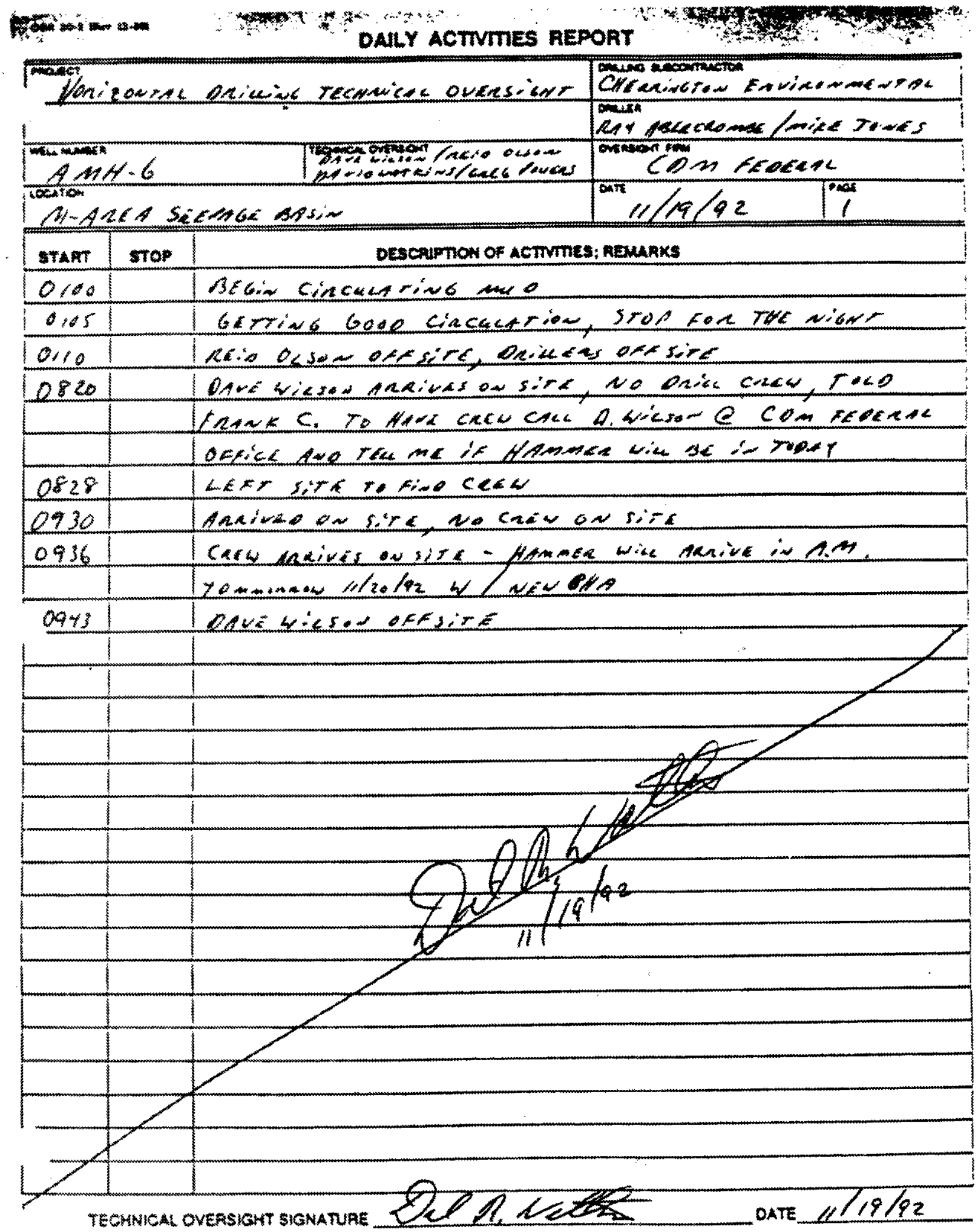


Demonstration of River Crossing Technology for Installation of Environmental Horizontal Wells: AMH-6 and AMH-7 Installation Repon CDM Federal Programs Corporation May 5.1993
Westinghouse Savannah River Company Subcontract No. AA46325P Task Order No. 10

r.w.

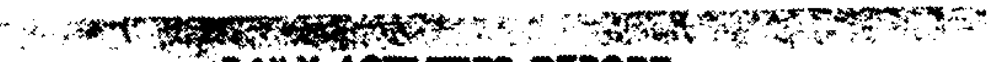
$\sin ^{2} x$ *ALY ACTVMES REPORT

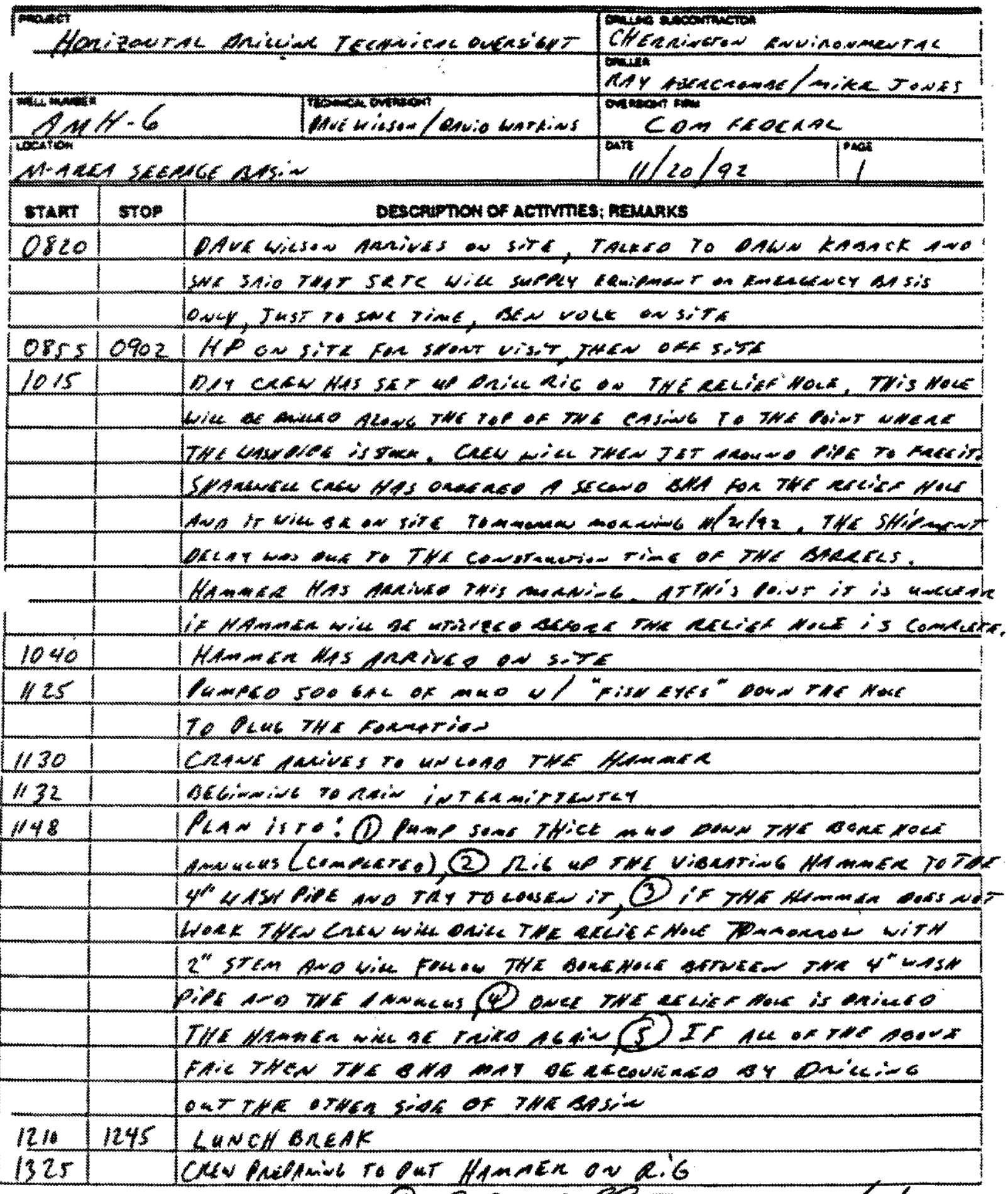

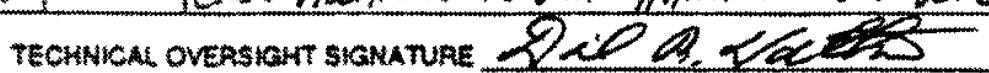
DATE $1 / 21 / 92$ B-22 
Demonstration of River Crossing Technology for Installation of Environmental Hoxizontal Wells: AMH-6 and AMH-7 Installation Report CDM Federal Programs Corporation May 5, 1993
Westinghouse Savannah River Company

Subcontract No. AA46325P

Task Order No. 10

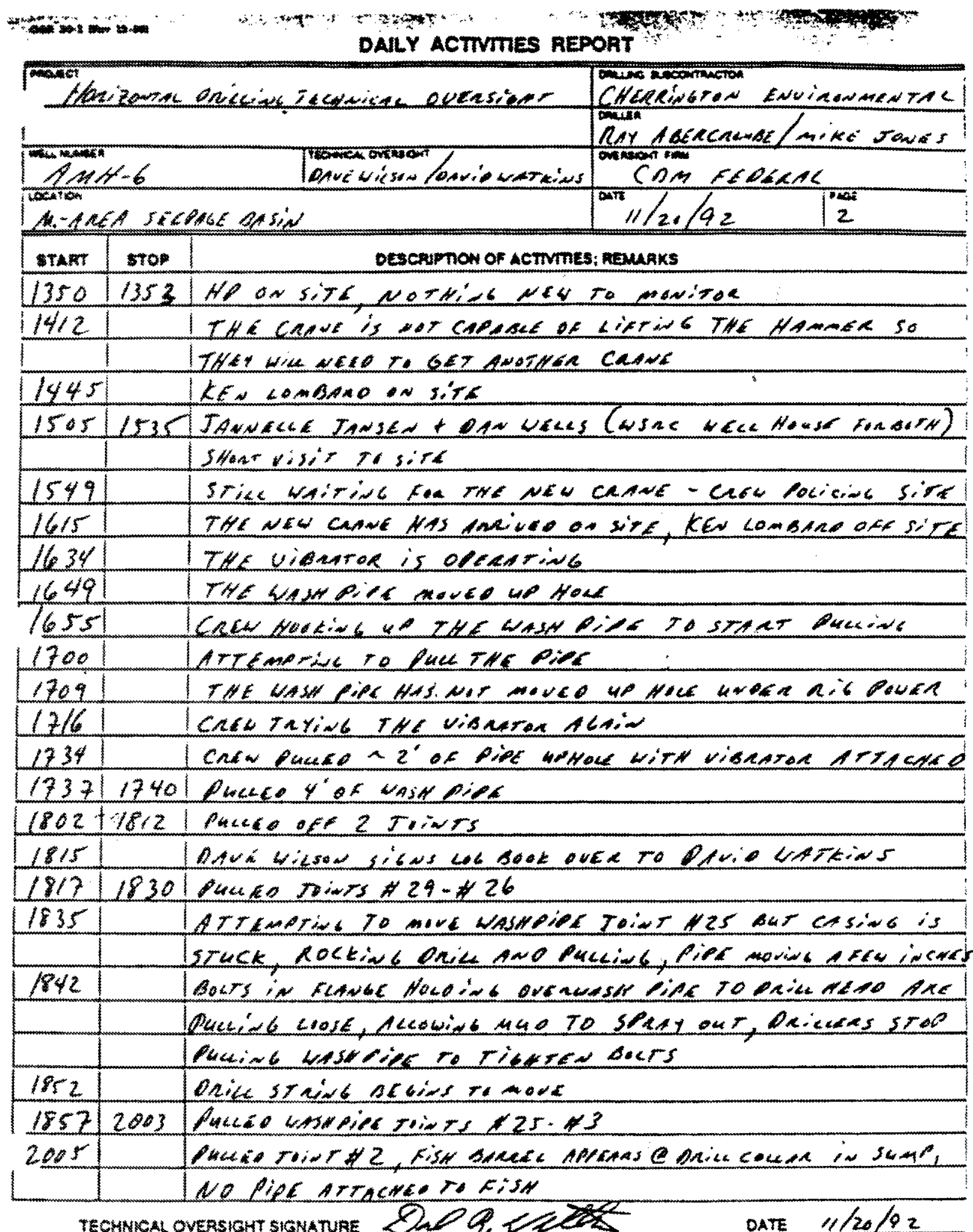


Demonstration of River Crossing Technology for Installation of Environmental Horizontal Wells: AMH-6 and AMH-7 Installation Repor CDM Federal Programs Comporation

May $\$, 1993$
Westinghouse Savannah River Company Subcontract No. AA46325P Task Order No. 10

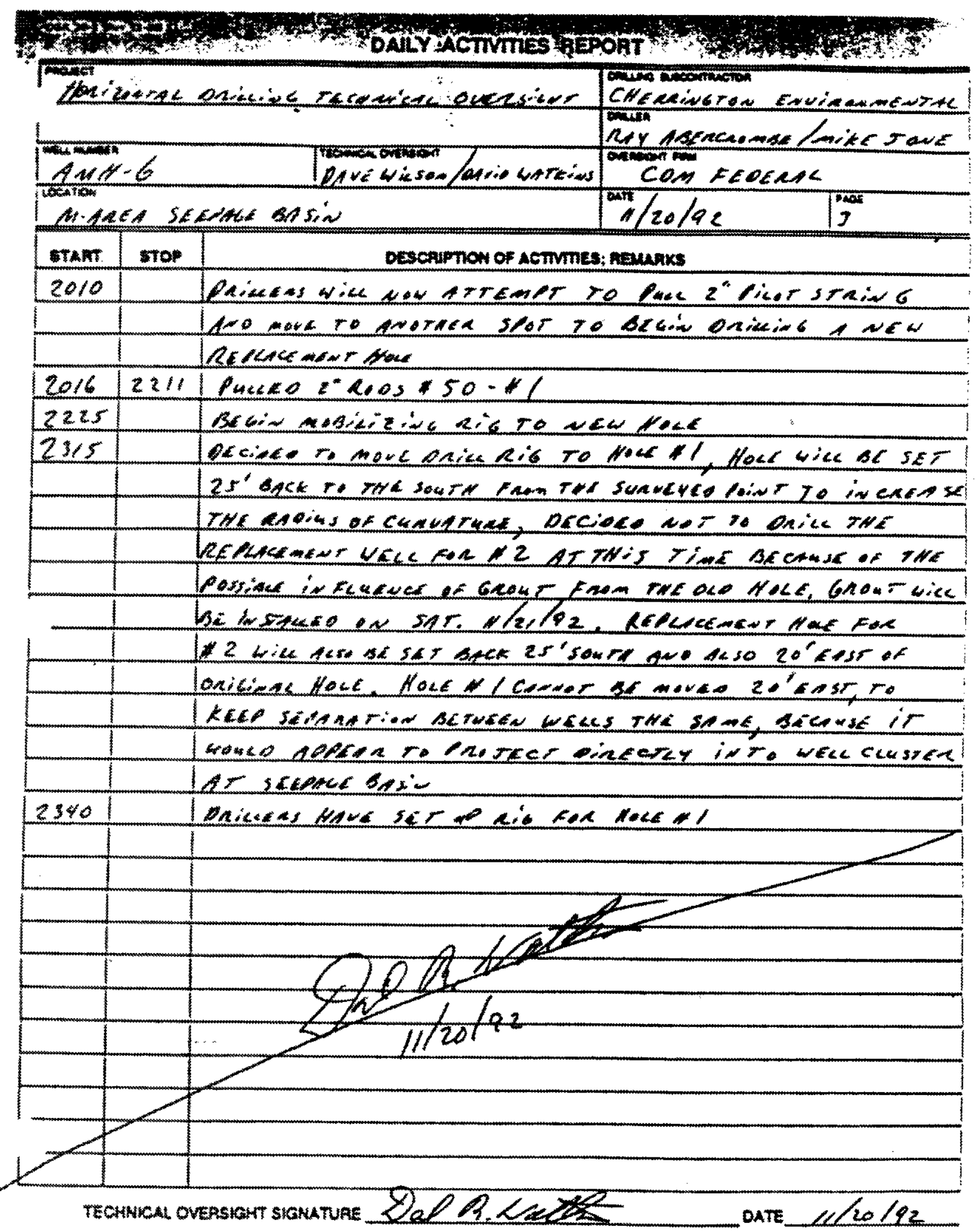

B-24 
Demonstration of River Crossing Technology for Installation of Environmental Horizontal Wells: AMH-6 and AMH-7 Installation Repon CDM Federal Programs Corporation

May 5,1993
Westinghouse Savannah River Company Subcontract No. AA46325P Task Order No. 10

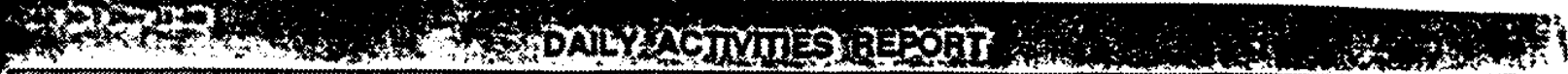

(3) Wok

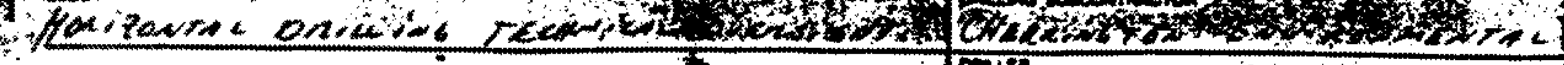

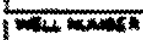
$4 M \not y-7$

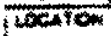
Descom $M+A R E A$ SEAQAGC $B O \sin$

\begin{tabular}{|c|c|c|c|c|}
\hline stant & stop & $11 / 21 / 42$ \\
\hline
\end{tabular}

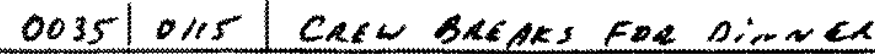

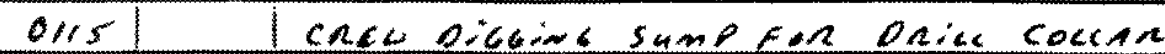

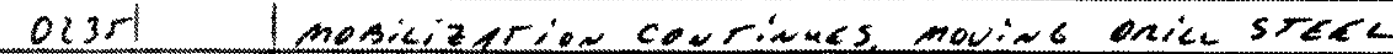

03,5 0325l daikens on coeter bLCAk

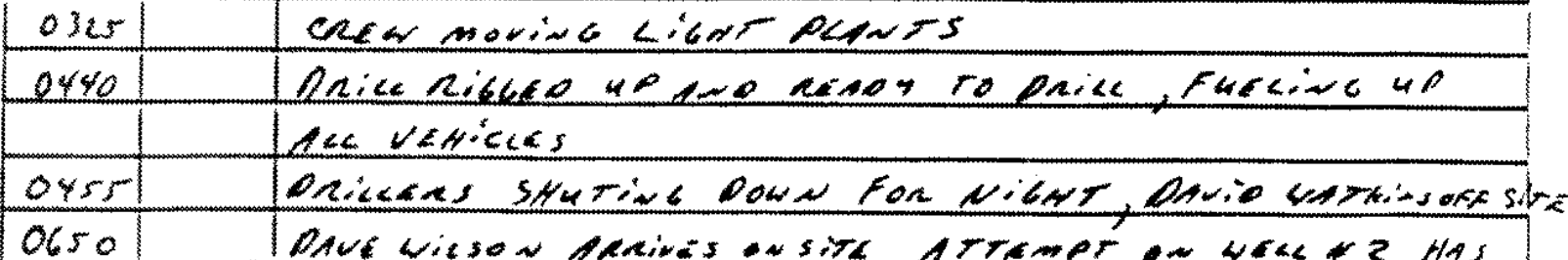

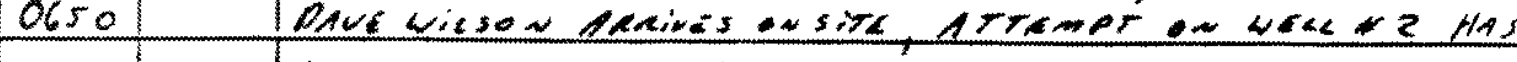

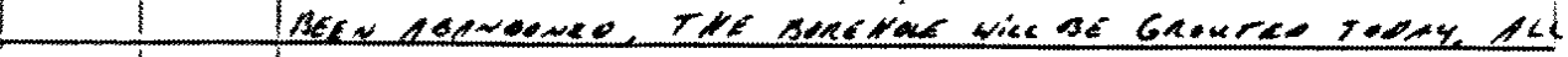

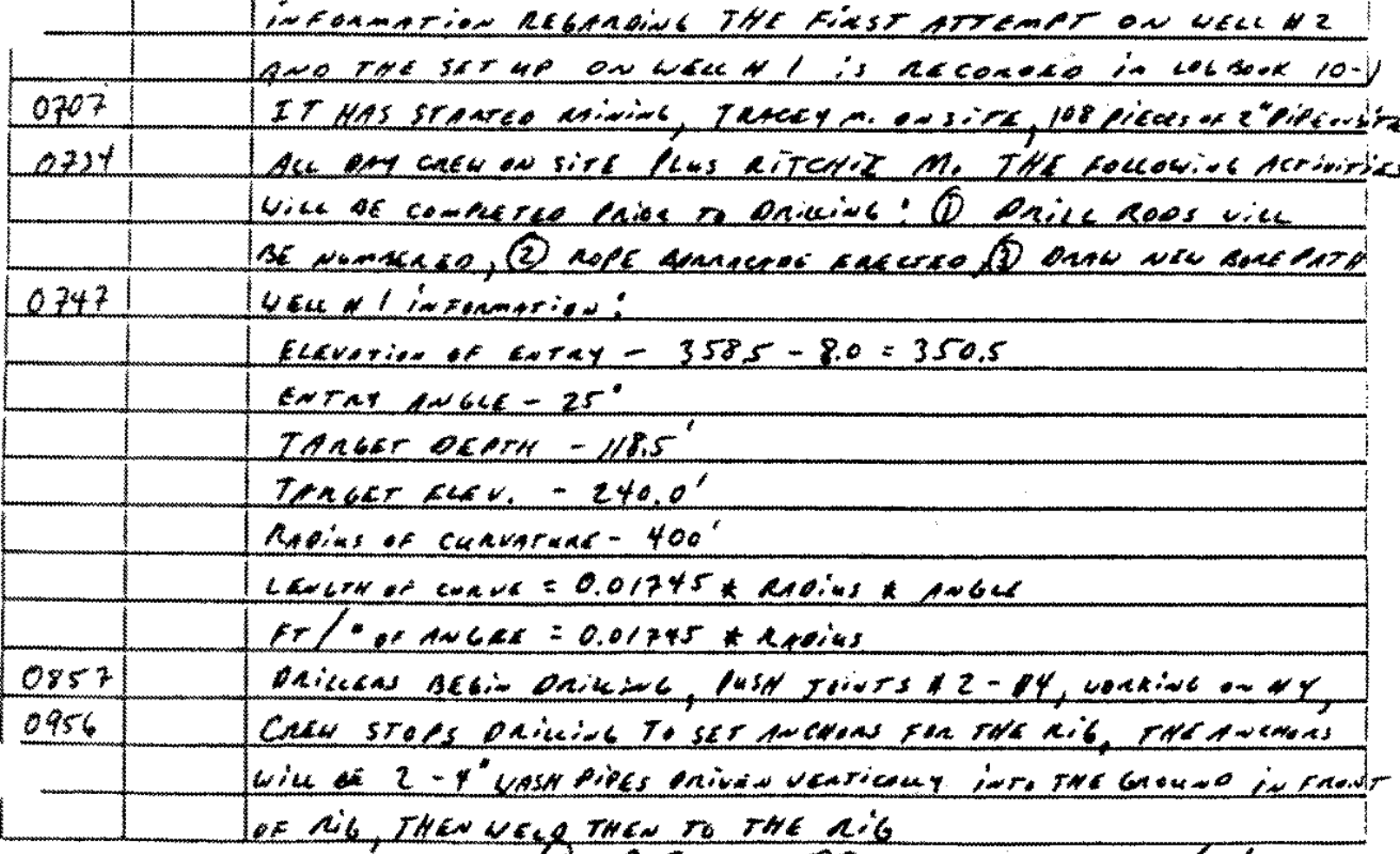

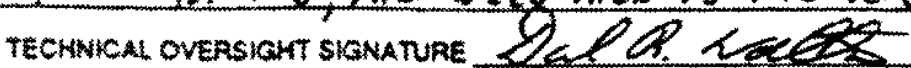

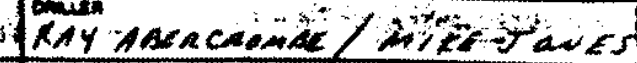

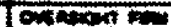
Com ficenta 
Demonstration of River Crossing Technology for Installation of Enviroamental Horizontal Wells: AMH-6 and AMH-7 Installation Repor CDM Fecieral Programs Corporation May 5,1993
Westinghouse Savannah River Company Subcontract No. AA46325P Task Order No. 10

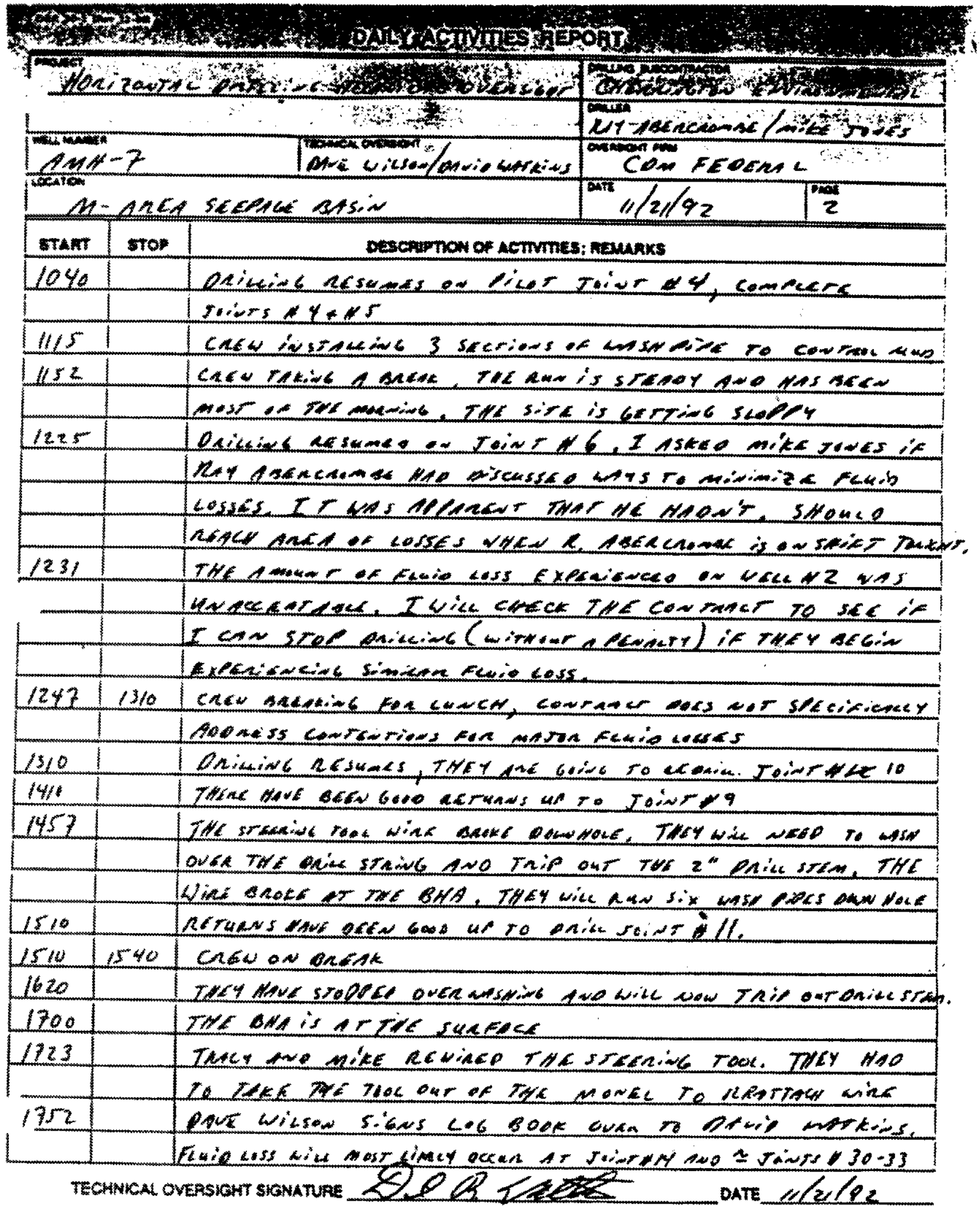


Demonstration of River Crossing Technology for Installation of Environmental Horizontal Wells: AMH-6 and AMH-7 Installation Report CDM Federal Programs Corporation

May 5,1993
Westinghouse Savannah River Company Subcontract No. AA46325P Task Order No. 10

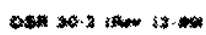

DAILY ACTVITES REPOAT

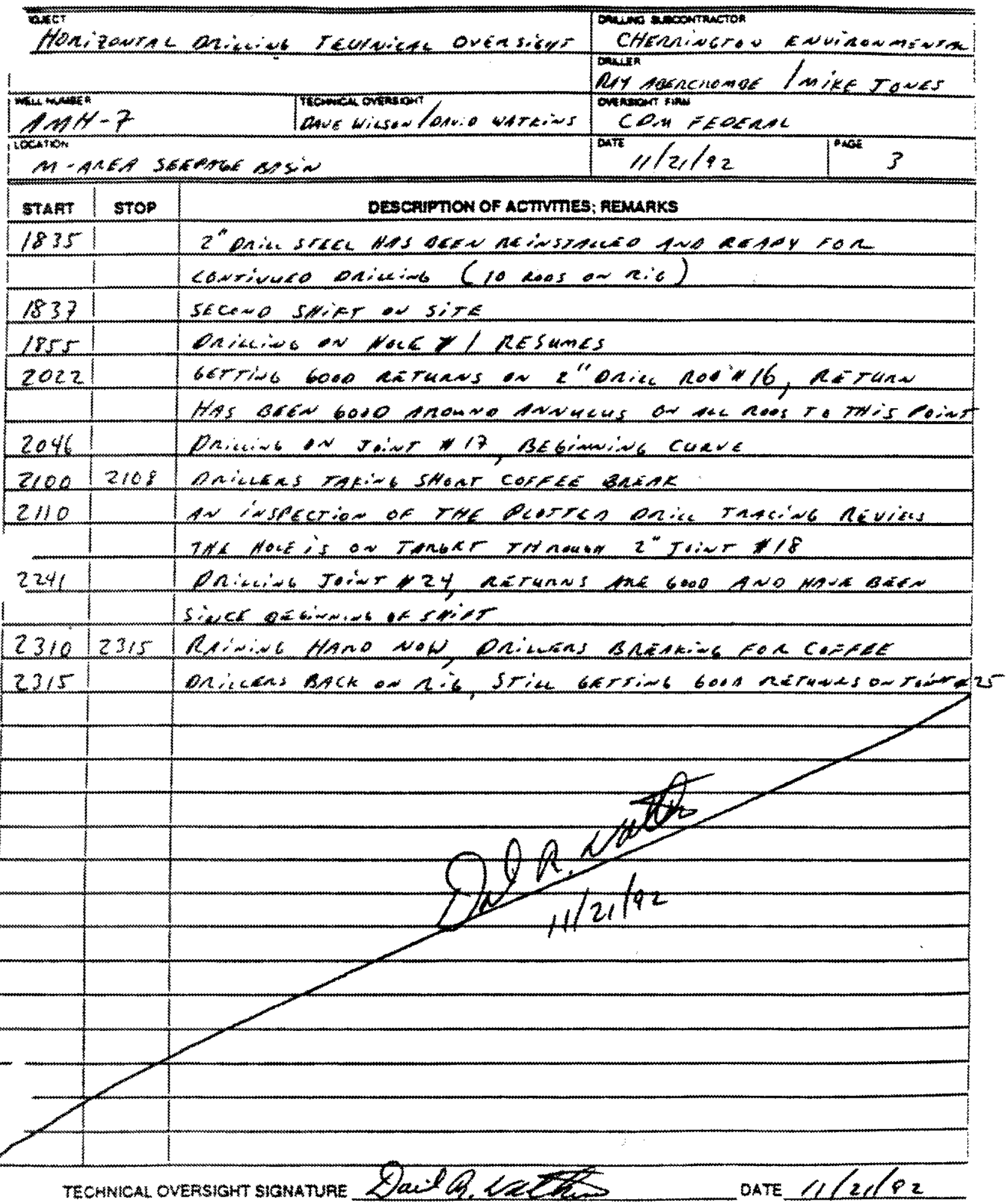


Demonstration of River Crossing Technology for Installation of Envirocmental Horizontal Wells: AMH-6 and AMH-7 Installation Report CDM Federal Programs Corporation

May S, 1993

Westinghouse Savannah River Company Subcontract No. AA46325P

Task Order No. 10

-1.2.

DAILY ACTIVIIES REPORT

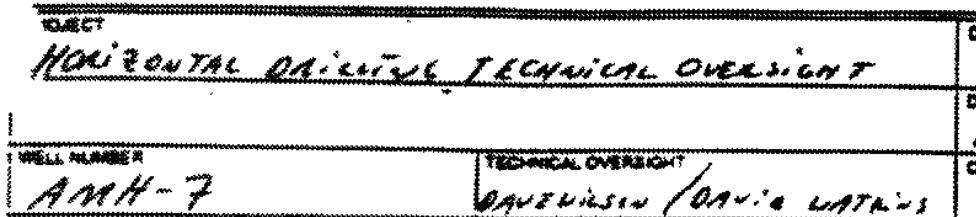

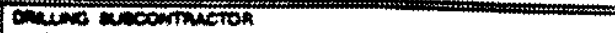

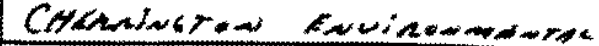

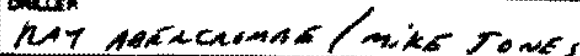

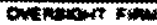

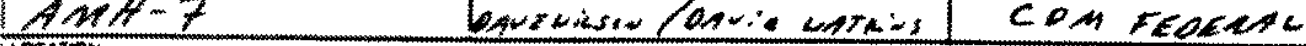

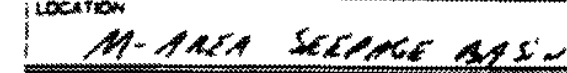
$11 / 22 / 92$

\begin{tabular}{|c|c|c|}
\hline START & stop & 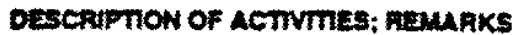 \\
\hline
\end{tabular}

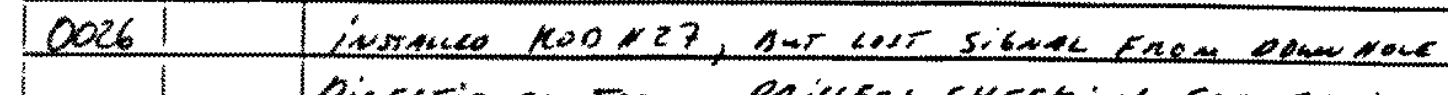

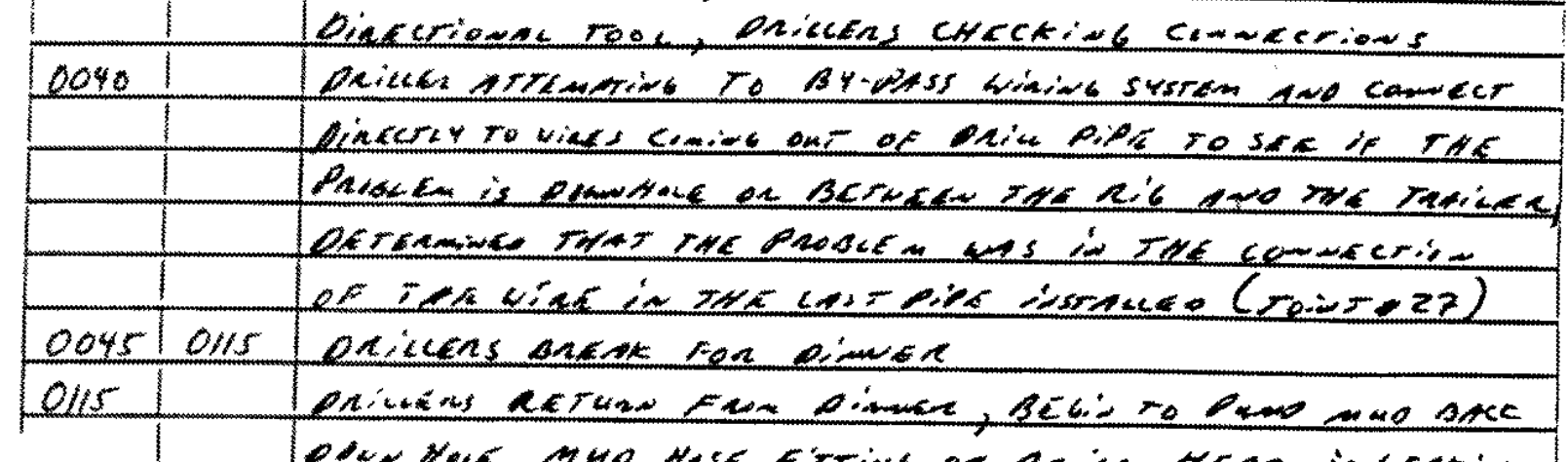

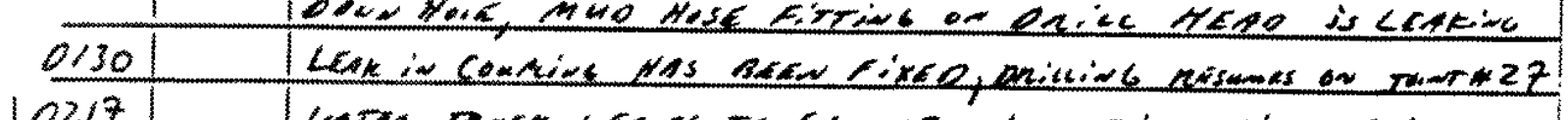

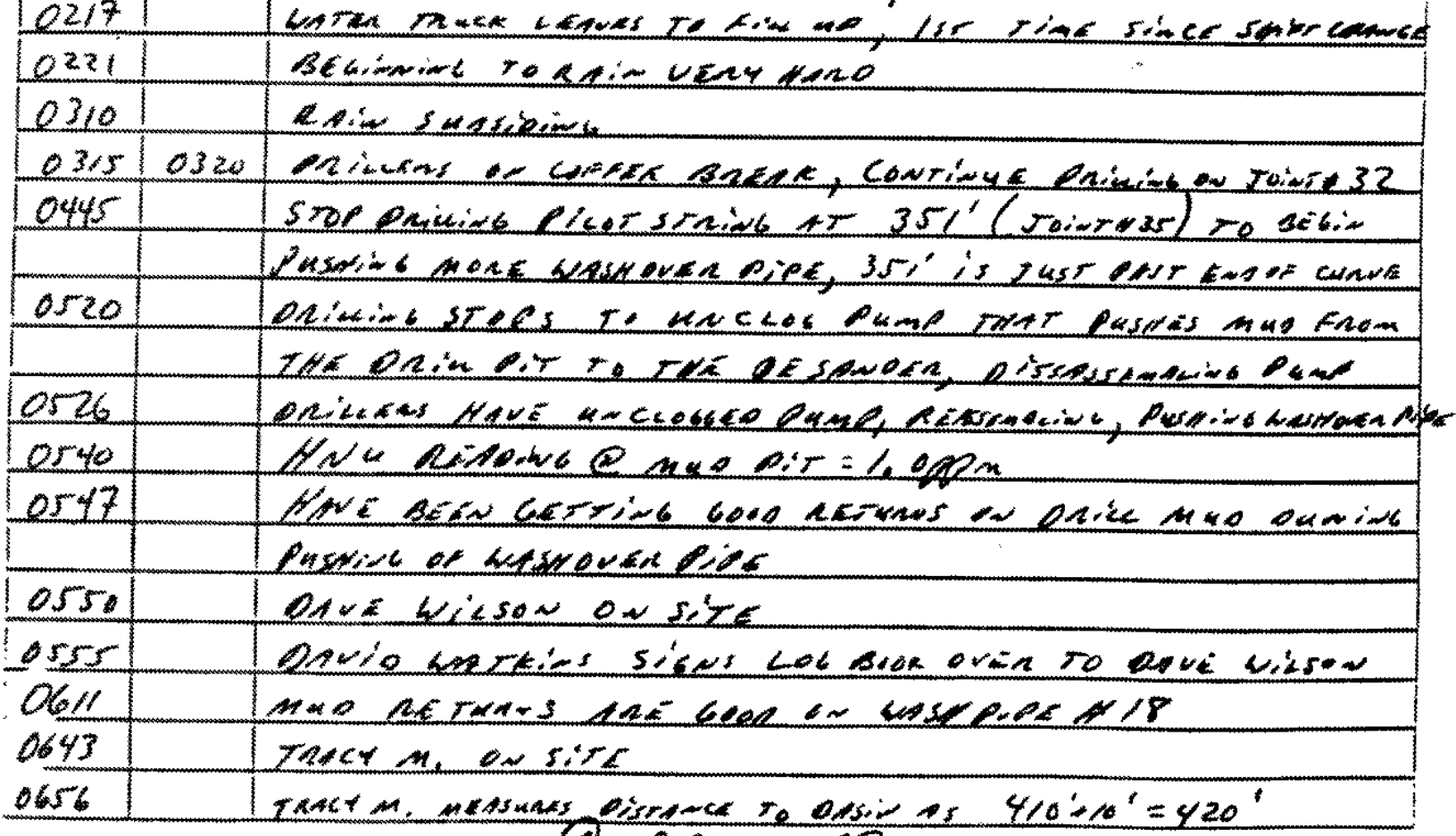

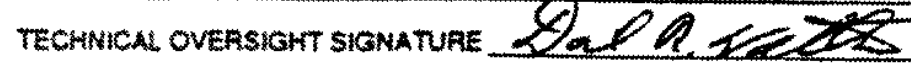
DATE $/ / 22 / 92$ 
Demonstration of River Crossing Technology for Installation of Environmental Horizontal Wells: AMH-6 and AMH-7 Installation Report CDM Federal Programs Corporation May 5, 1993
Westinghouse Savannah River Company Subcontract No. AA46325P Task Order No. 10

ox* $20.3=32$

DALIY ACTIVITES REPORT

\begin{tabular}{|c|c|c|}
\hline \multirow{2}{*}{\multicolumn{3}{|c|}{ 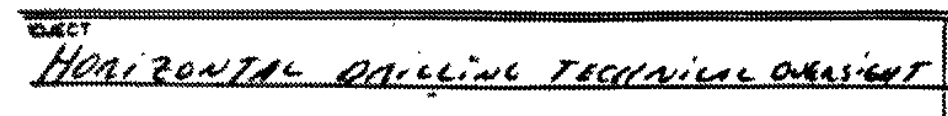 }} \\
\hline \multirow{2}{*}{\multicolumn{3}{|c|}{ 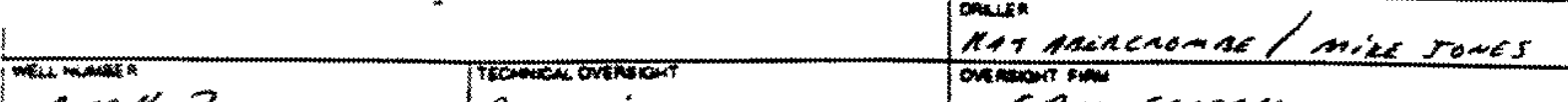 }} \\
\hline & & \\
\hline \multicolumn{2}{|c|}{$M-A R C A$} & $11 / 22 / 92$ \\
\hline START & stop & DESCRIPnON OF ACTVMES; REMARKS \\
\hline 0701 & & Det cres on sire \\
\hline \multirow[t]{5}{*}{$07 / 3$} & & 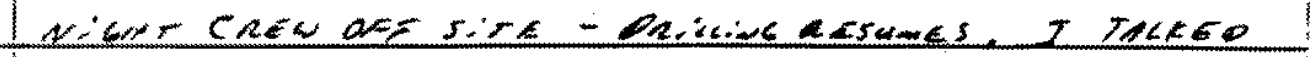 \\
\hline & & 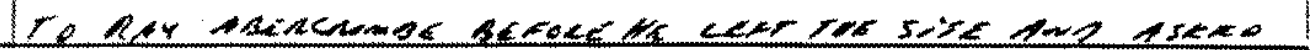 \\
\hline & & 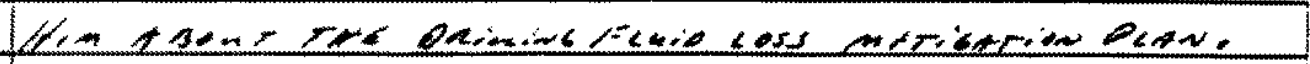 \\
\hline & & 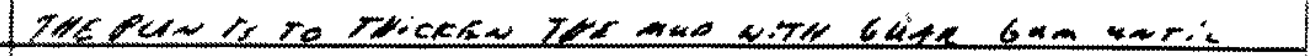 \\
\hline & & 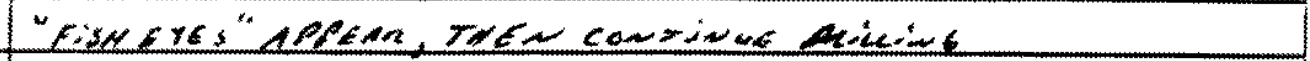 \\
\hline \multirow[t]{4}{*}{0332} & & 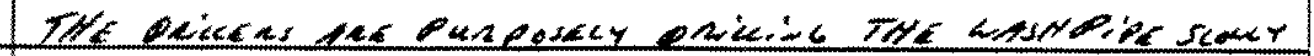 \\
\hline & & 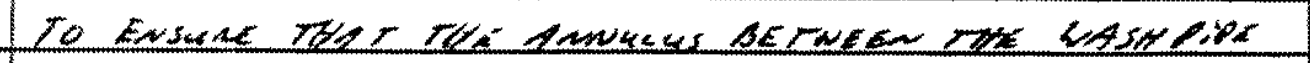 \\
\hline & & 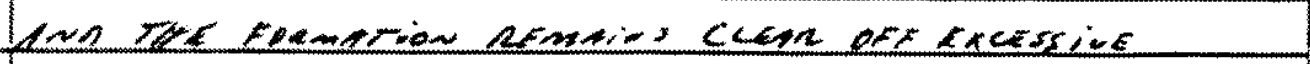 \\
\hline & & 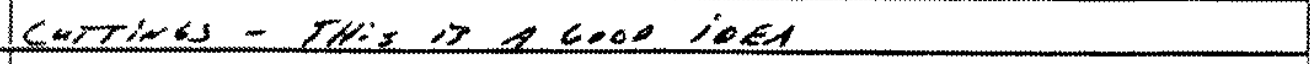 \\
\hline 080 & & 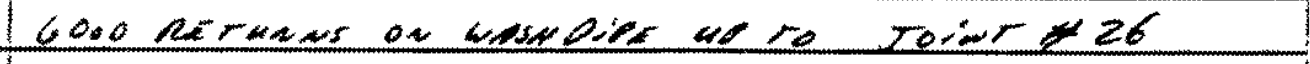 \\
\hline 080 & & 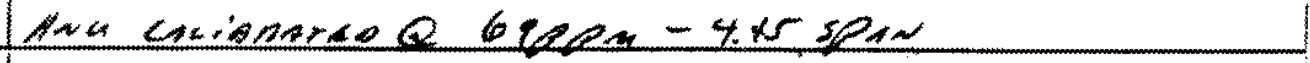 \\
\hline \multirow[t]{2}{*}{ Ders } & & 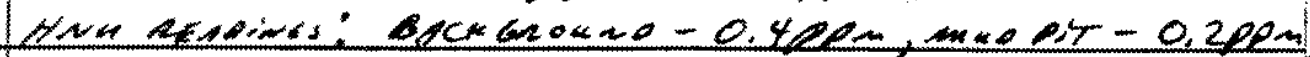 \\
\hline & & 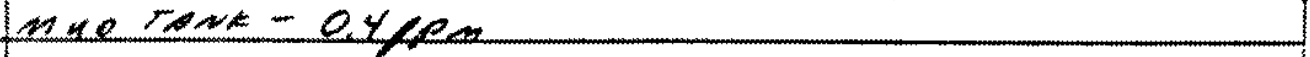 \\
\hline 082 & & 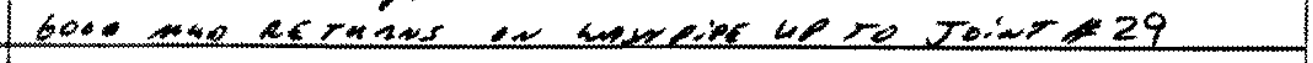 \\
\hline \multirow[t]{2}{*}{0.85} & & 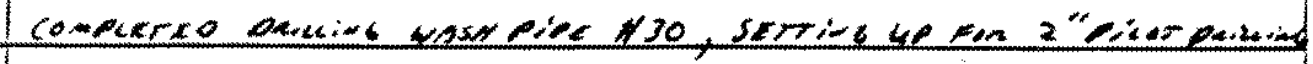 \\
\hline & & 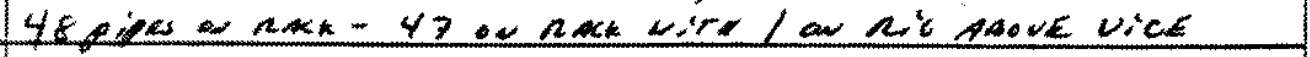 \\
\hline \multirow[t]{4}{*}{$0 \% 1$} & & 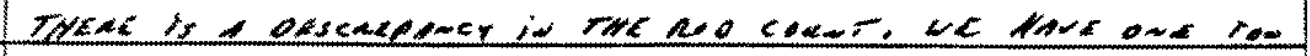 \\
\hline & & If we ane opt \&y awe ritr en $0^{\prime}$ \\
\hline & & 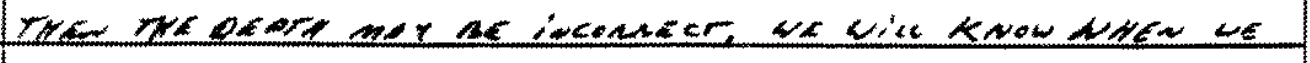 \\
\hline & & 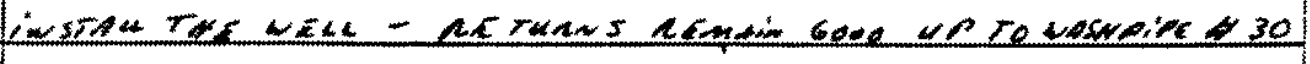 \\
\hline \multirow[t]{2}{*}{0712} & & 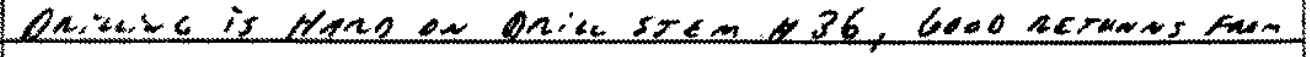 \\
\hline & & 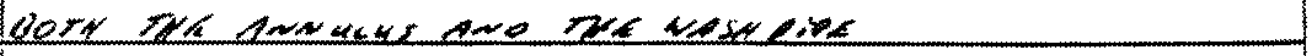 \\
\hline 2931 & & AMO PAESSun is 750 psi \\
\hline \multirow[t]{3}{*}{0932} & & 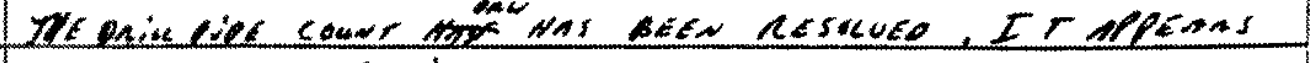 \\
\hline & & 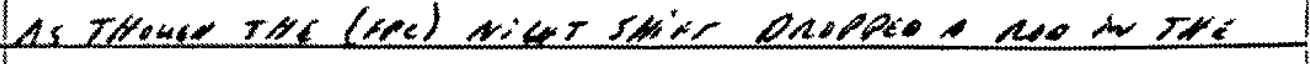 \\
\hline & & Nod cowar \\
\hline 0939 & & 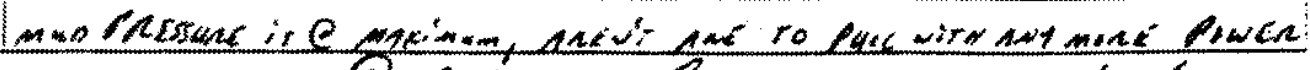 \\
\hline
\end{tabular}

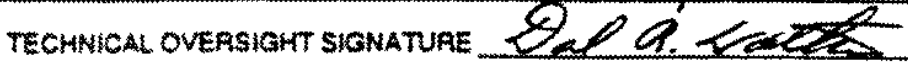
DATE $1 / 22 / 92$ 
Demonstration of River Crossing Tochnology for Installation of Enviroamental Horizontal Wells: AMH-6 and AMH-7 Installation Report CDM Federal Programs Corporation May 5, 1993
Westinghouse Savannah River Company Subcontract No. AA46325P Task Order No. 10

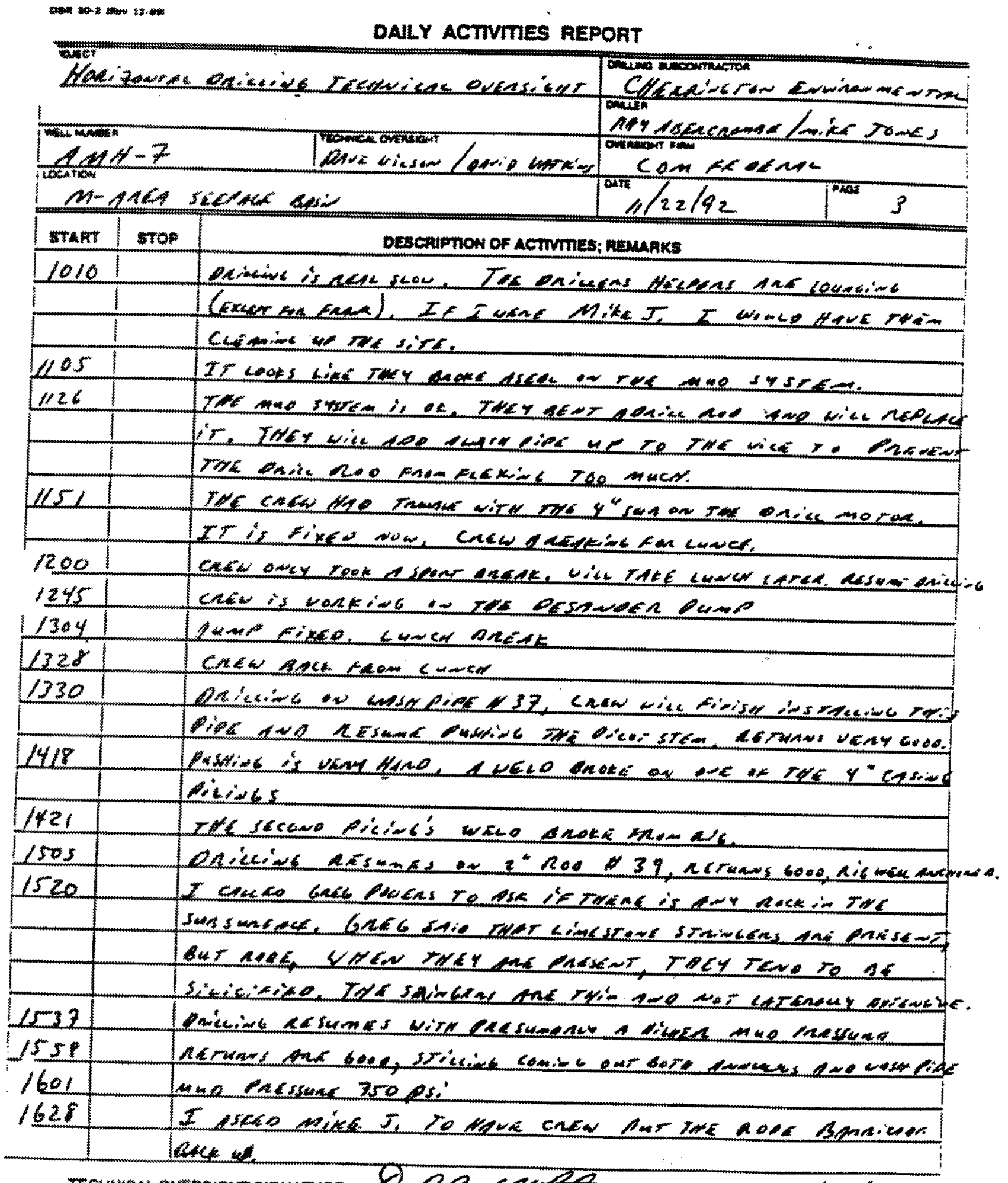

TECHWICA OVERSICHT SIGNATURE \&) PQ TEZ DATE $1 / 22 / 92$ 
Demonstration of River Crossing Technology for Installation of Environmental Horizontal Wells: AMH-6 and AMH-7 Installation Report CDM Federal Programs Corporation

May 5,1993
Westinghouse Savannah River Company Subcontract No. AA46325P

Task Order No. 10

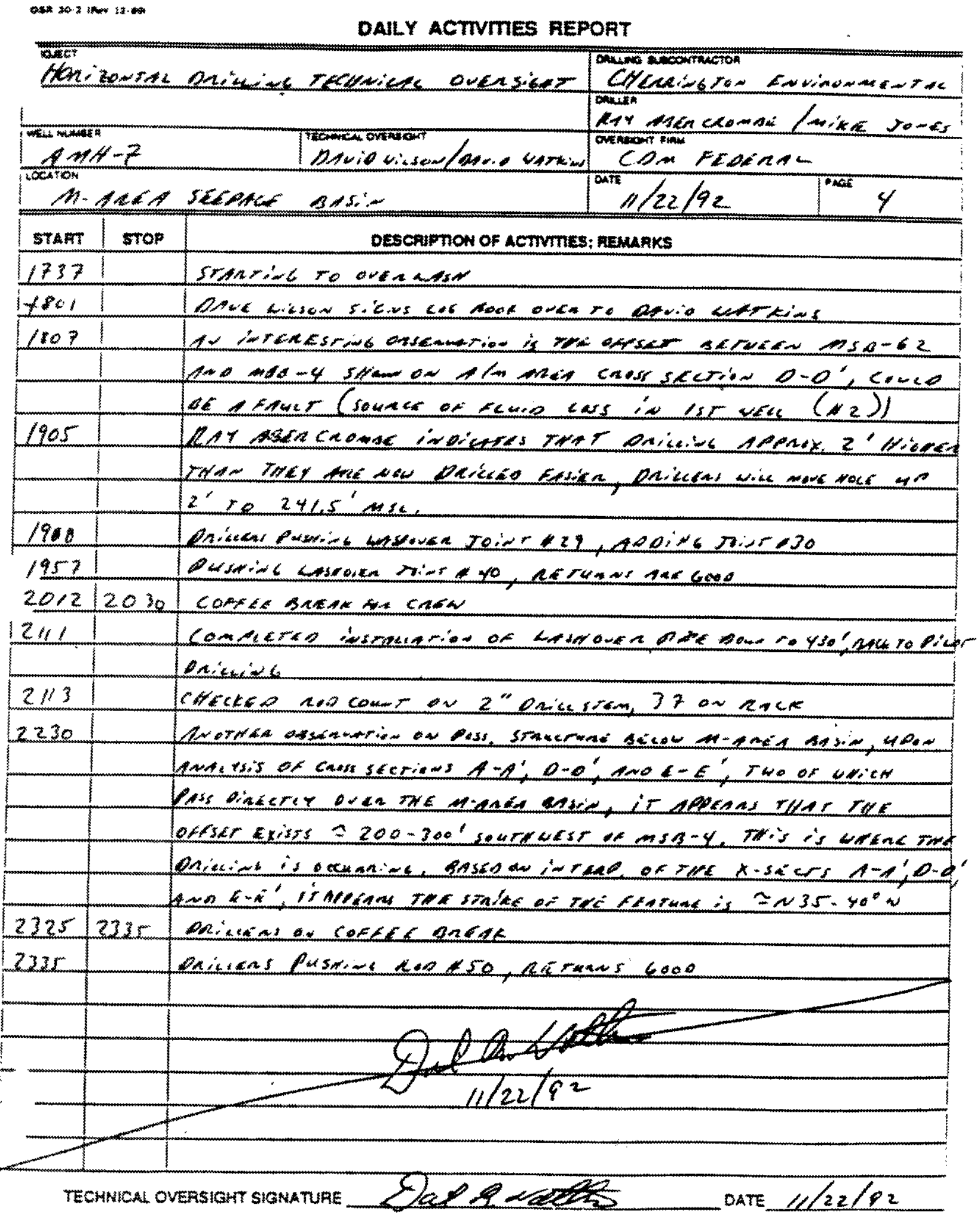


Demostration of River Crossing Technology for Installation of Eavironmental Horizontal Wells: AMH-6 and AMH-7 Installation Report COM Federal Programs Corporation

May 5,1993
Westinghouse Savannah Ríver Company Subcontract No. AA46325P

-14

DAILY ACTIVITES REPOAT

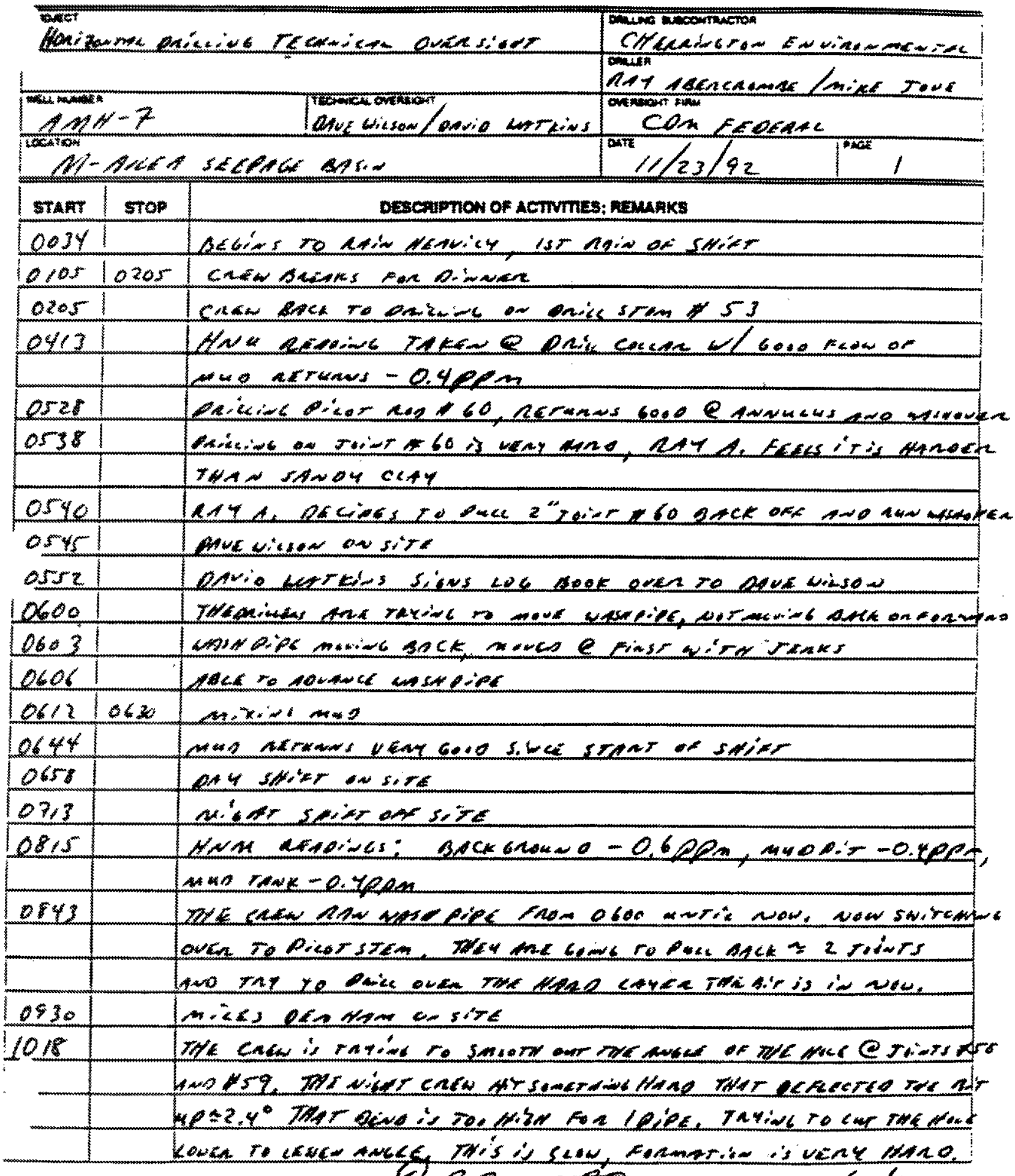

TEOHNCAL OVERIOHT SKSNATURE $4+26+2$ DATE $1 / / 23 / 12$ 
Deznonstration of River Crossing Technology for Installation of Westinghouse Savannah River Company Environmental Horizontal Wells: AMH-6 and AMH-7 Installation Report CDM Federal Programs Corporation

Subcontract No. AA46325P

May 5.1993

Task Order No. 10

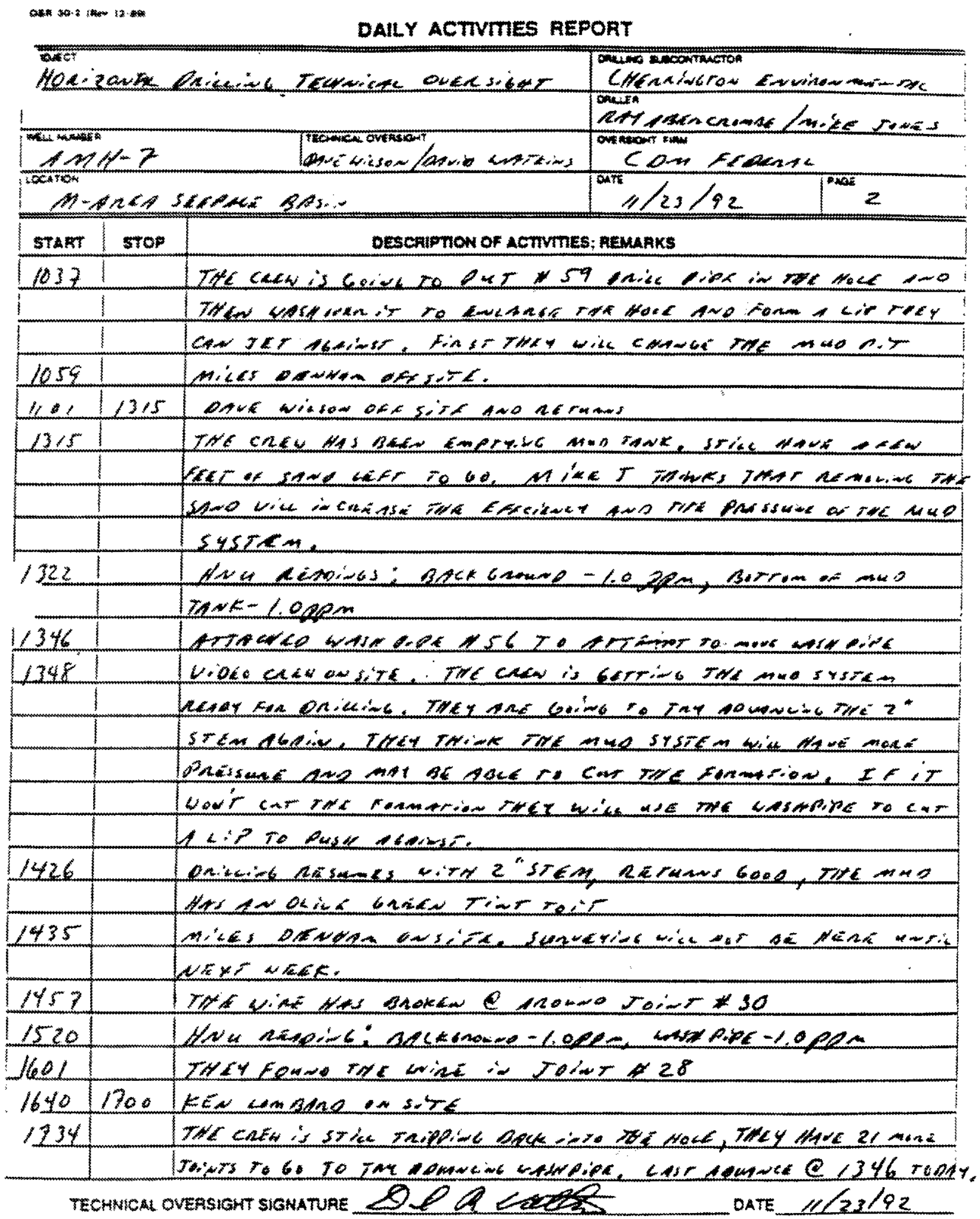


Demonstration of River Crossing Technology for Installation of Enviroumental Horizontal Wells: AMH-6 and AMH-7 lnstallation Report CDM Federal Programs Corporation

Westinghouse Savannah River Company May \$, 1993

Subcontract No. AA46325P Task Order No. 10

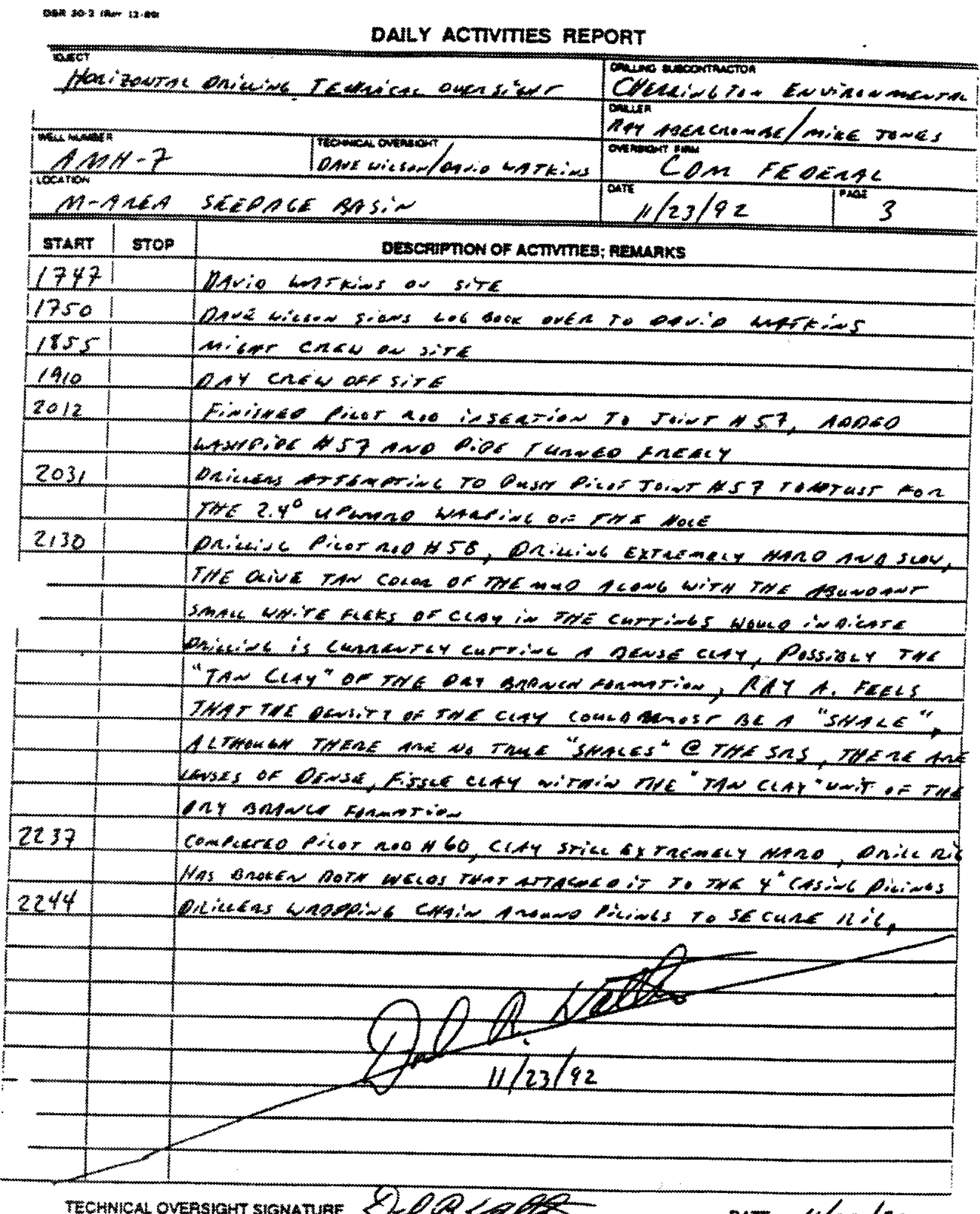

TECHNICAL OVEASHOHT SIGNATURE DATE $11 / 23 / 92$ 
Demonstration of River Crossing Technology for Installation of Eevironmental Horizontal Wells: AMH-6 and AMH-7 Installation Repon CDM Federal Programs Corporation May 5, 1993
Westinghouse Savannah River Company Subcontract No. AA46325P Task Order No. 10

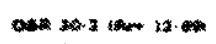

DALY ACTVITES REPORT

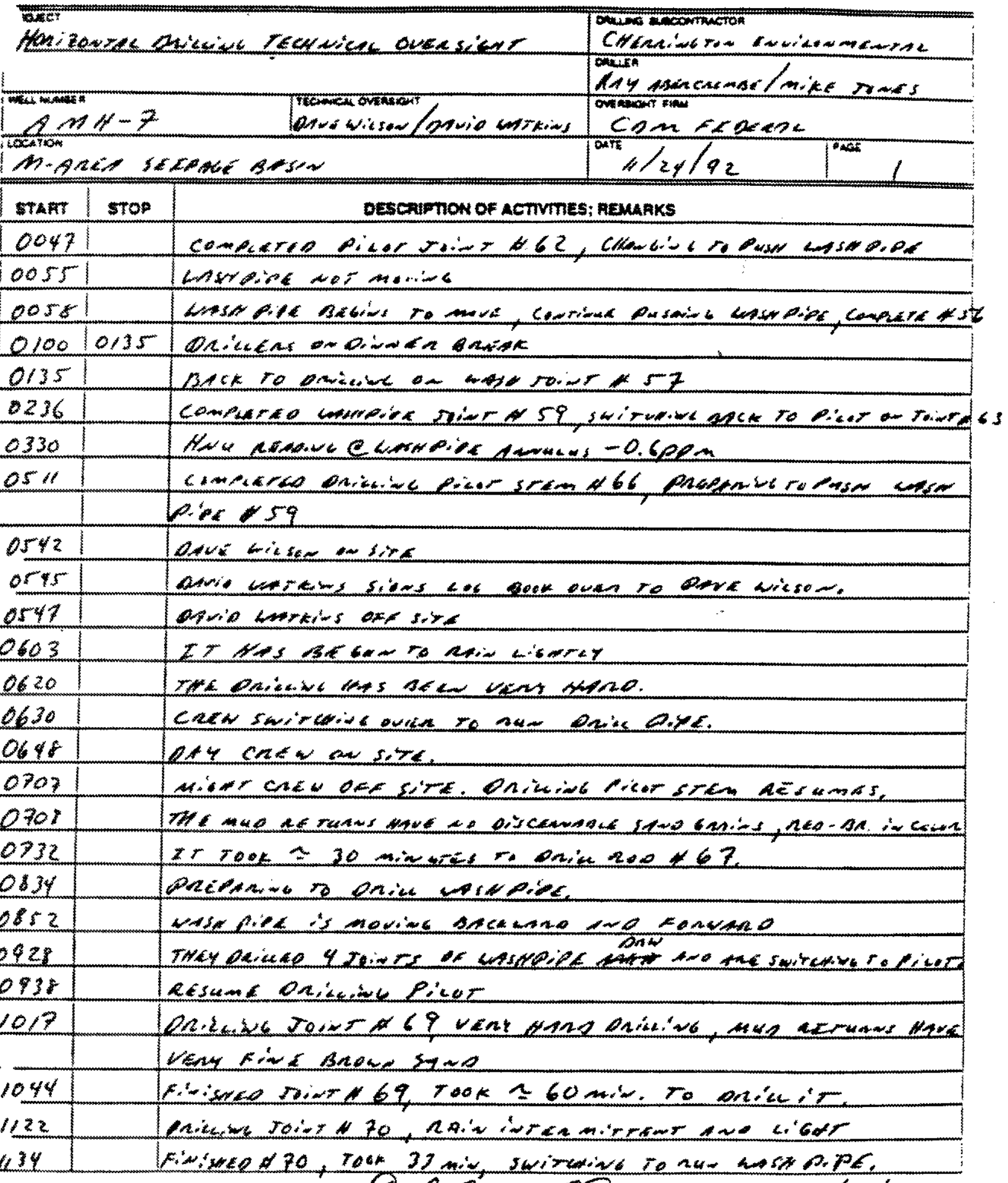

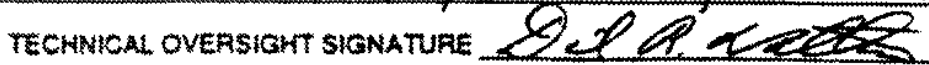
DATE $1 / 2 / 24 / 92$ 
Demonstration of River Crossing Technology for Installation of Environmental Horizontal Wells: AMH-6 and AMH-7 Installation Report CDM Federal Programs Corporation May 5.1993
Westinghouse Savannah River Company Subcontract No. AA46325P Task Order No. 10

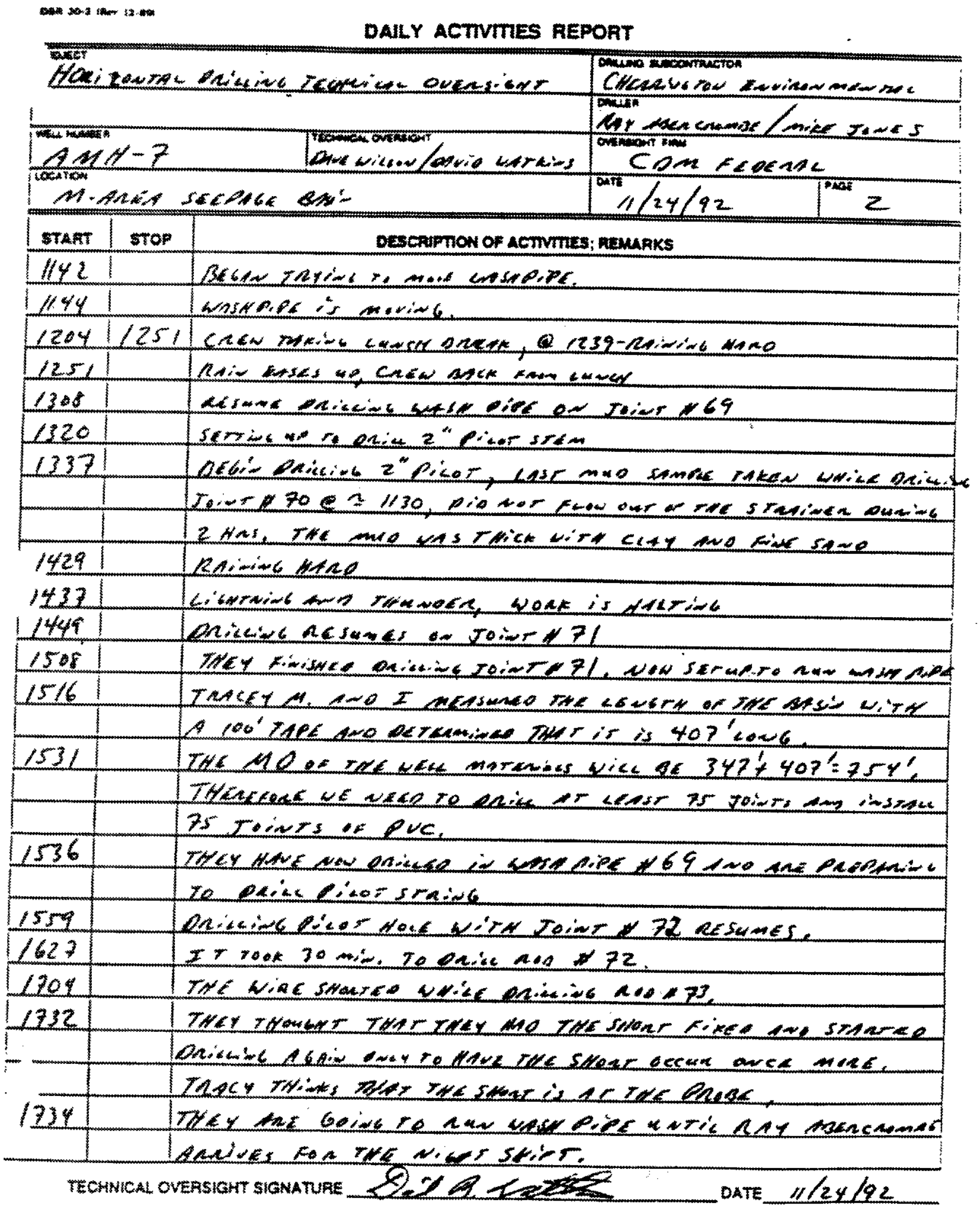


Dewonstration of River Crossing Technology for Installation of Environmental Horizontal Wells: AMH-6 and AMH-7 Installation Report CDM Federal Programs Corporation

May 5,1993
Westinghouse Savarnah River Company Subcontract No. AA46325P Task Order No. 10

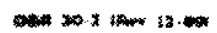

DAILY ACTIVTES REPORT

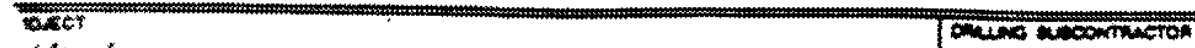

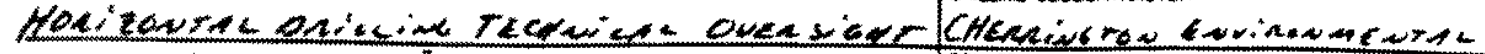
1 
Demonstration of River Crossing Technology for Installation of Enviroxmental Horizontal Wells: AMH-6 and AMH-7 installation Report CDM Foderal Programs Corporation

May \$. 1993
Westinghouse Savannah River Company

Subcontract No. AA46325P

Task Order No. 10

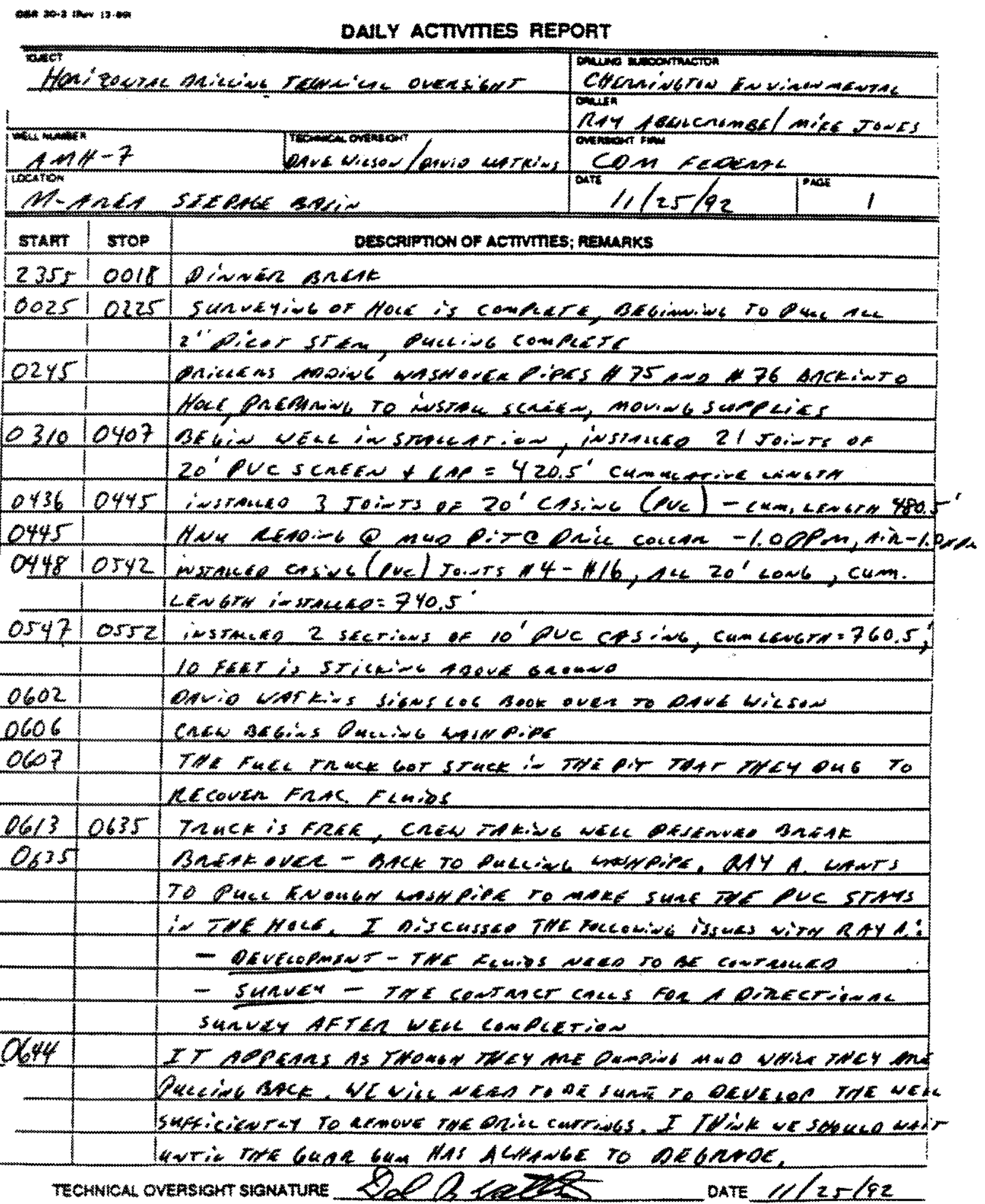


Demonstration of River Crossing Technology for Installation of Eswironmental Horizontal Wells: AMH-6 and AMH-7 Installation Repor CDM Federal Programs Corporation May \$, 1993
Westinghouse Savannab River Company Subcontract No. AA46325P Task Order No. 10

atom 20.20

DALY ACTVITES REPORT

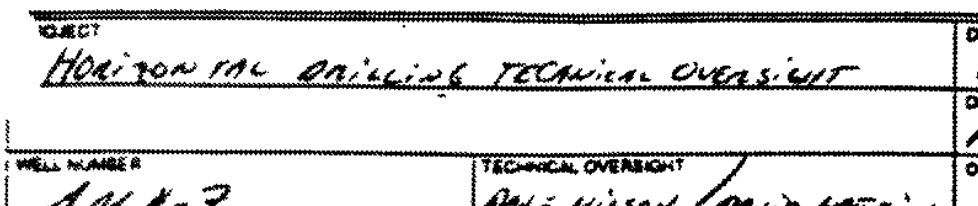

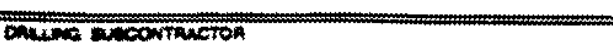

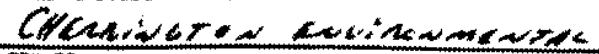
ontings

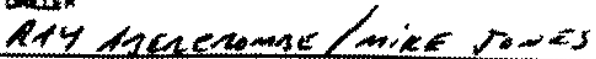
ormentiont A.

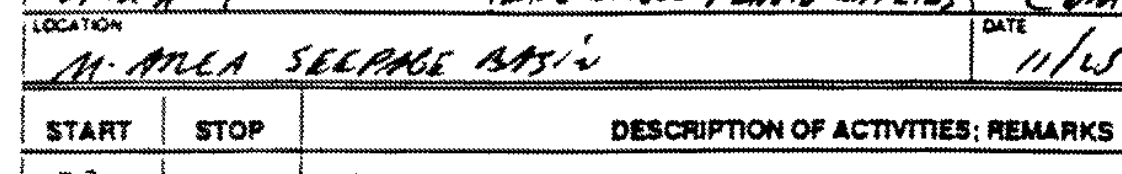
con thenc Q7,2 lety stive en site

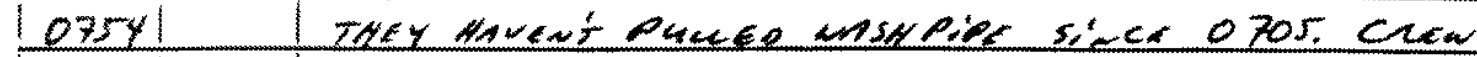

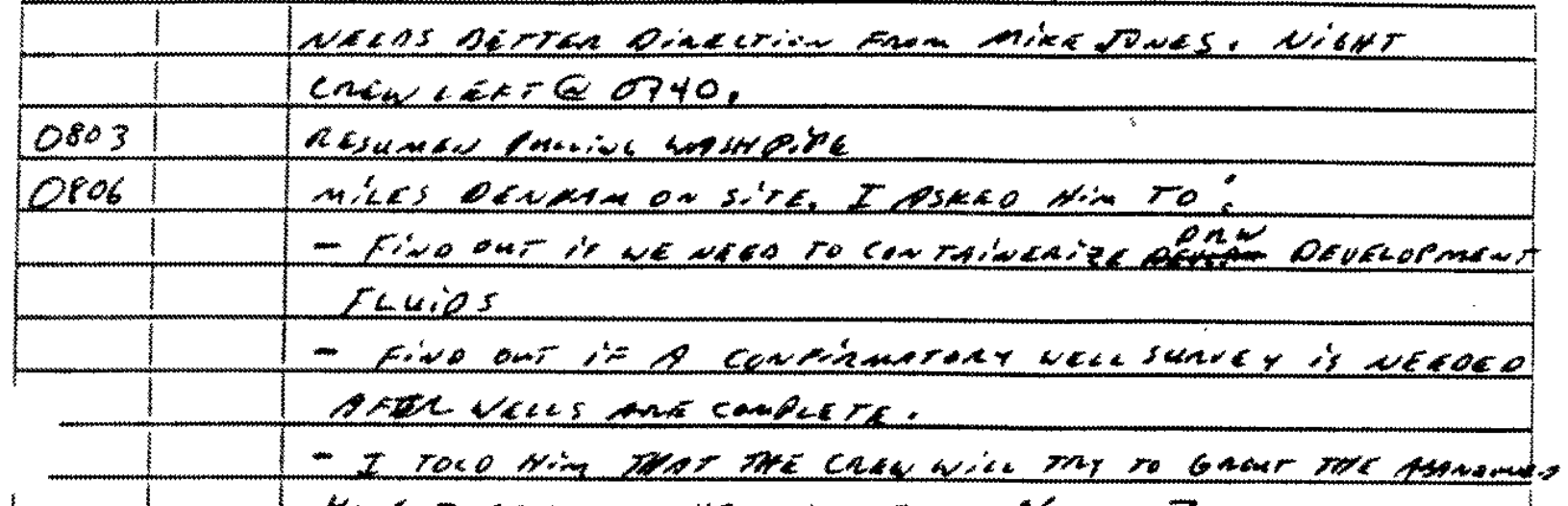

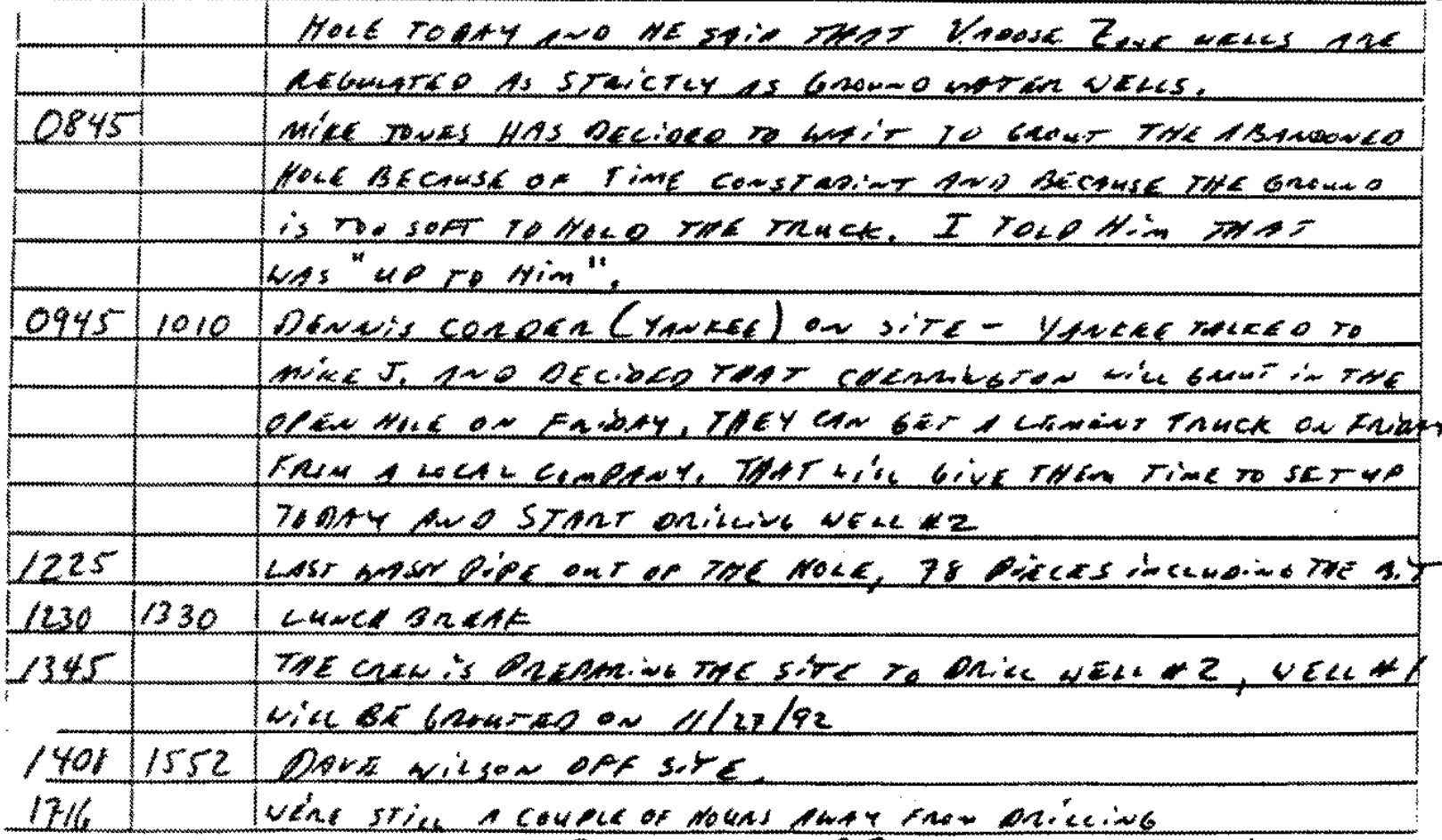

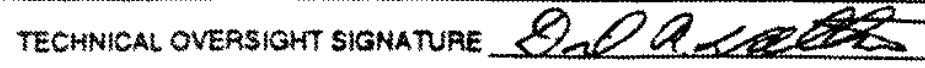
DATE $1 / 25 / 42$ 
Demonstration of River Crossing Technology for Installation of Westinghouse Savannah River Company

Environmental Horizontal Wells: AMH-6 and AMH-7 Installation Repon

COM Foderal Programs Corporation

Subcontract No. AA46325P

May 5, 1993

Task Order No. 10

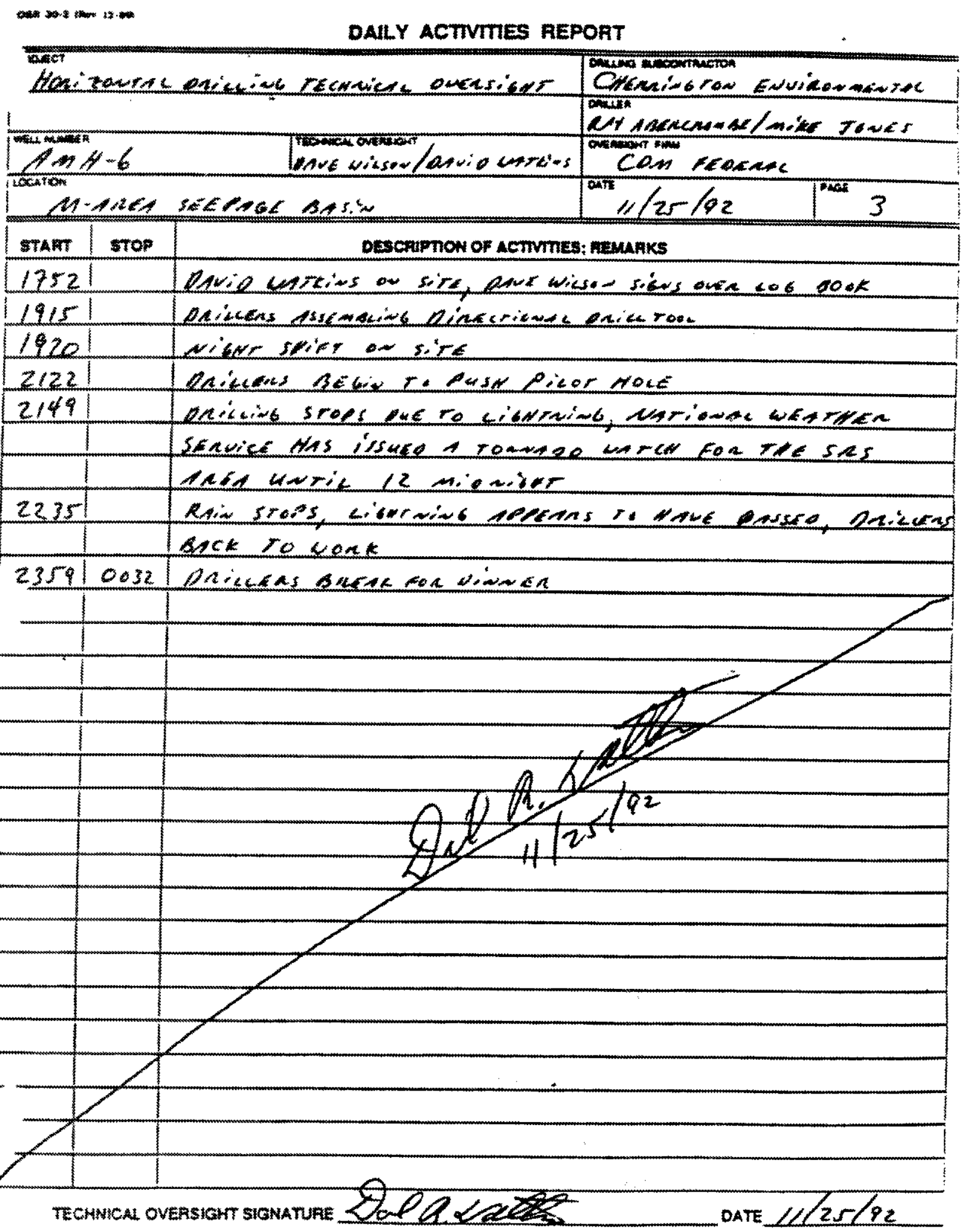

$B \cdot 40$ 
Demonstration of River Crossing Technology for Installation of Westinghouse Savannah River Company Environmental Horizontal Wells: AMH-6 and AMH-7 Installation Report Subcontract No. AA46325P CDM Federal Programs Corporation Task Order No. 10

May 5,1993

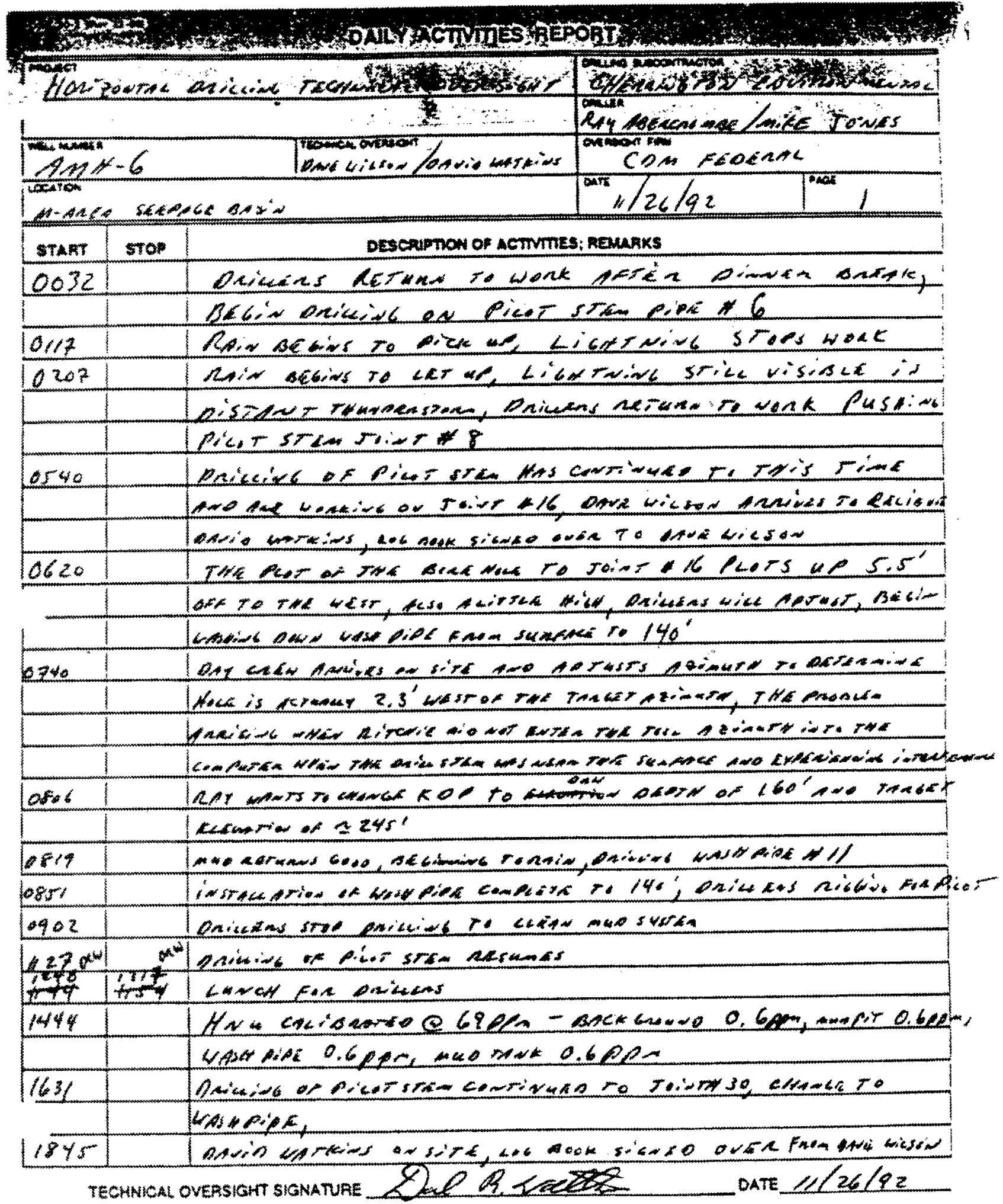


Dexacestration of River Crossing Technology for Installation of

EDMvironmental Horizontal Wells: AMH-6 and AMH-7 Installation Repont

Westinghouse Savannah River Company

May 5.1993

Subcontract No. AA46325P

Task Order No. 10

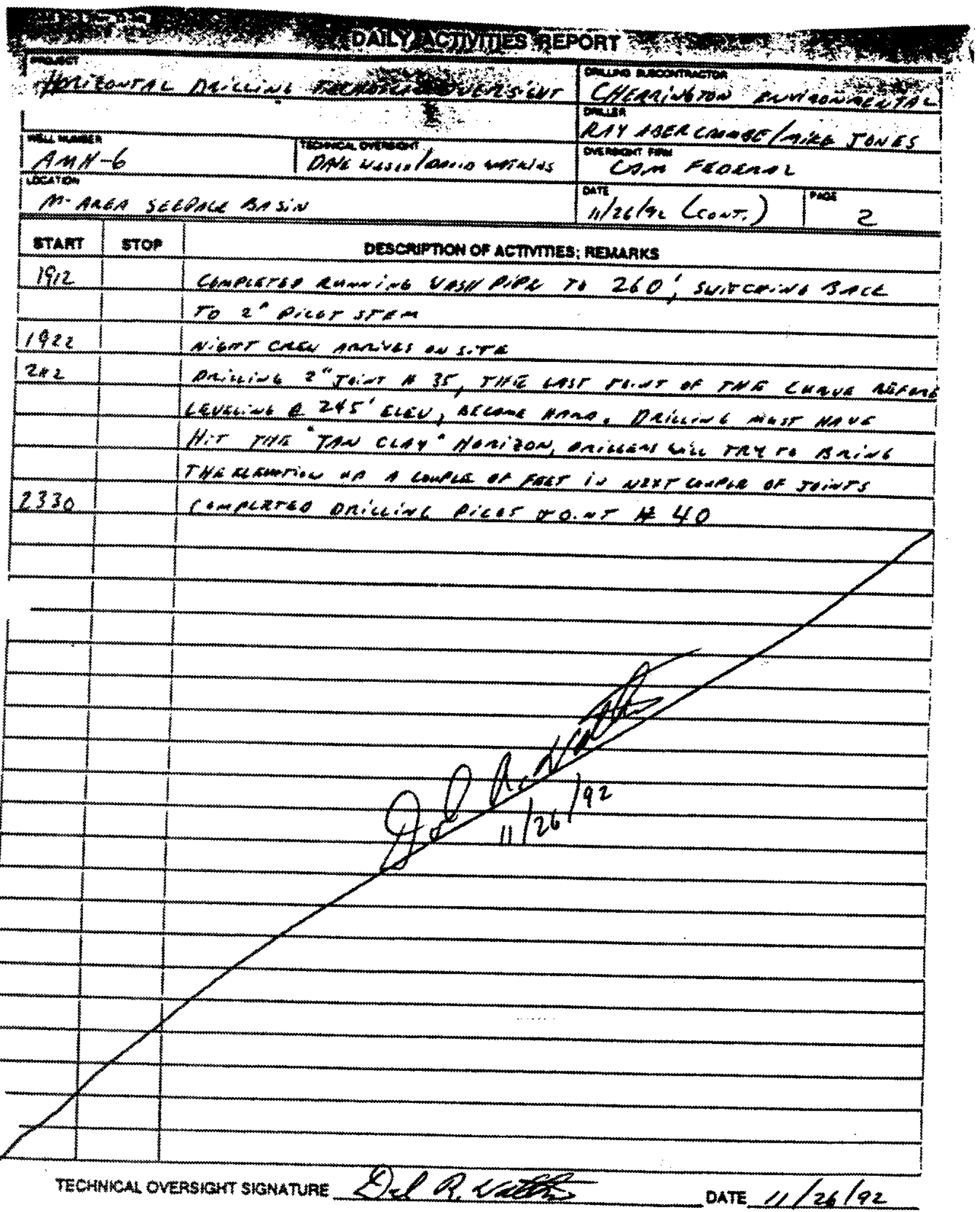


Demonstration of River Crossing Technology for Installation of Westinghouse Savannah River Company Environmental Horizontal Wells: AMH-6 and AMH-7 Installation Report CDM Federal Programs Corporation Subcontract No. AA46325P May 5, 1993 Task Order No. 10

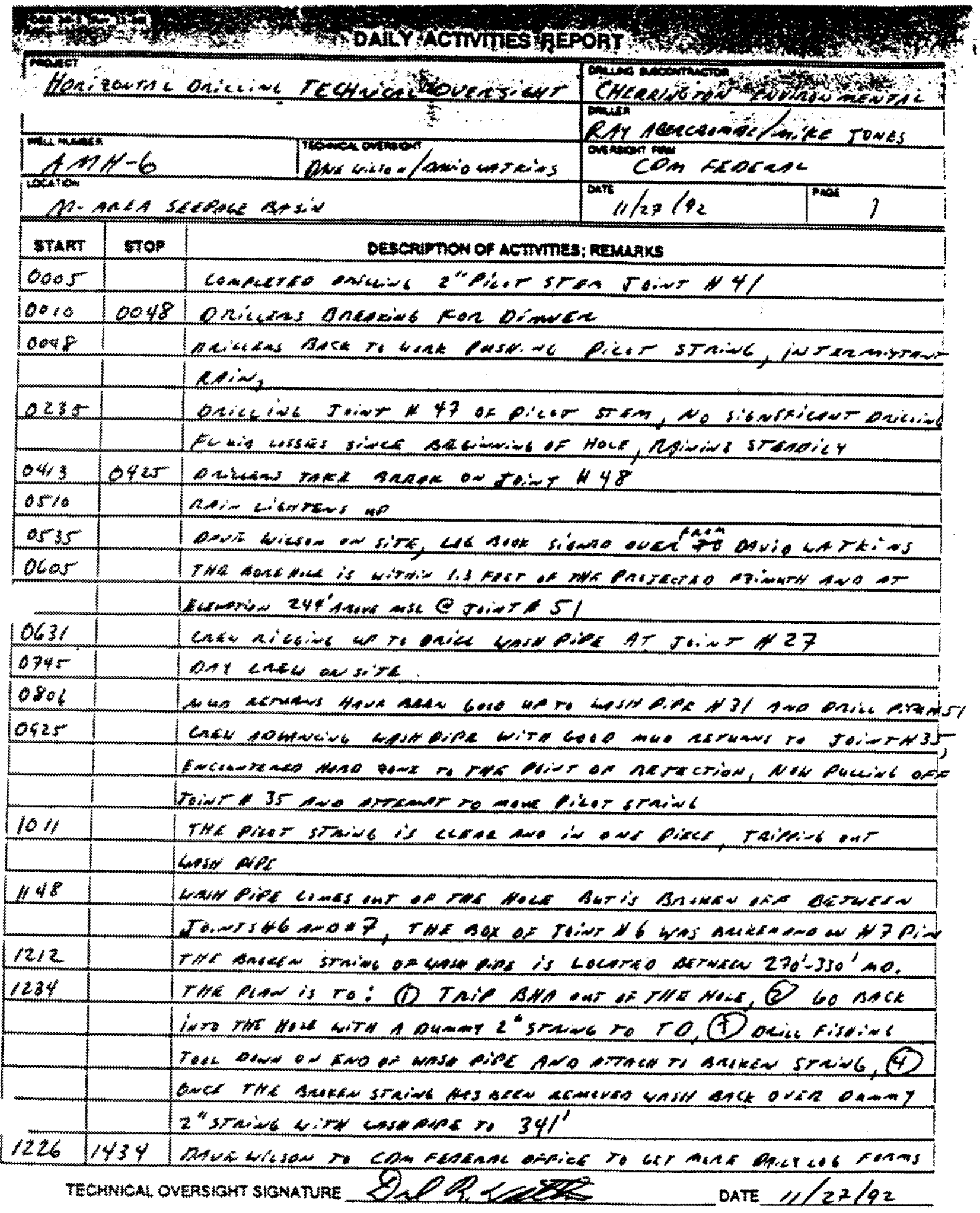


Demonstration of River Crossing Technology for lnstallation of Westinghouse Savannah River Company COM Federal Programs Corporation -6 and AMH-7 Installation Report Subcontract No. AA46325P May 5,1993

Task Ordar No. 10

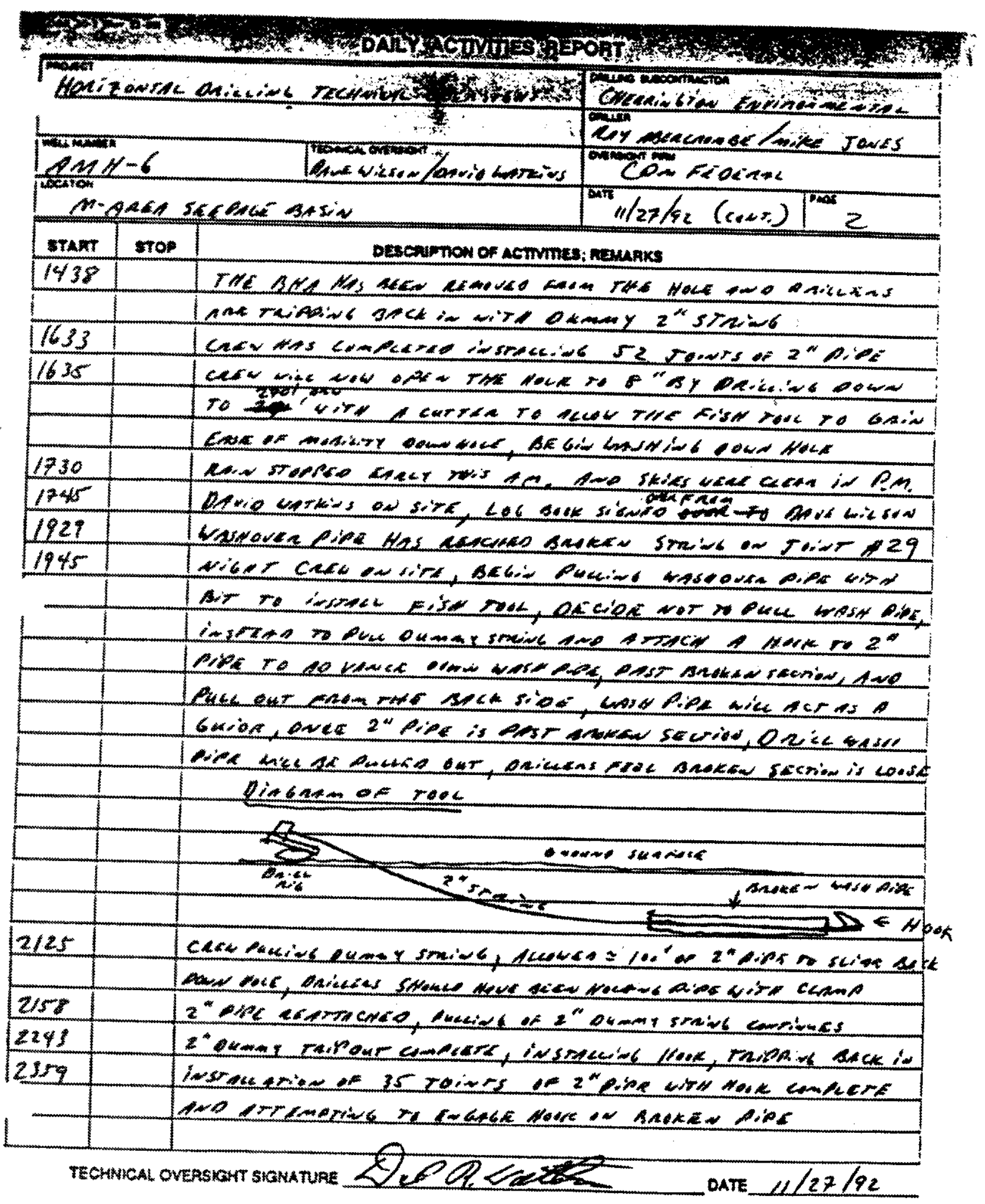


Demonstration of River Crossing Technology for Installation of Environmental Horizontal Wells: AMH-6 and AMH-7 Installation Repon CDM Federal Programs Corporation

May 5,1993
Westinghouse Savannah River Company Subcontract No. AA46325P Task Order No. 10

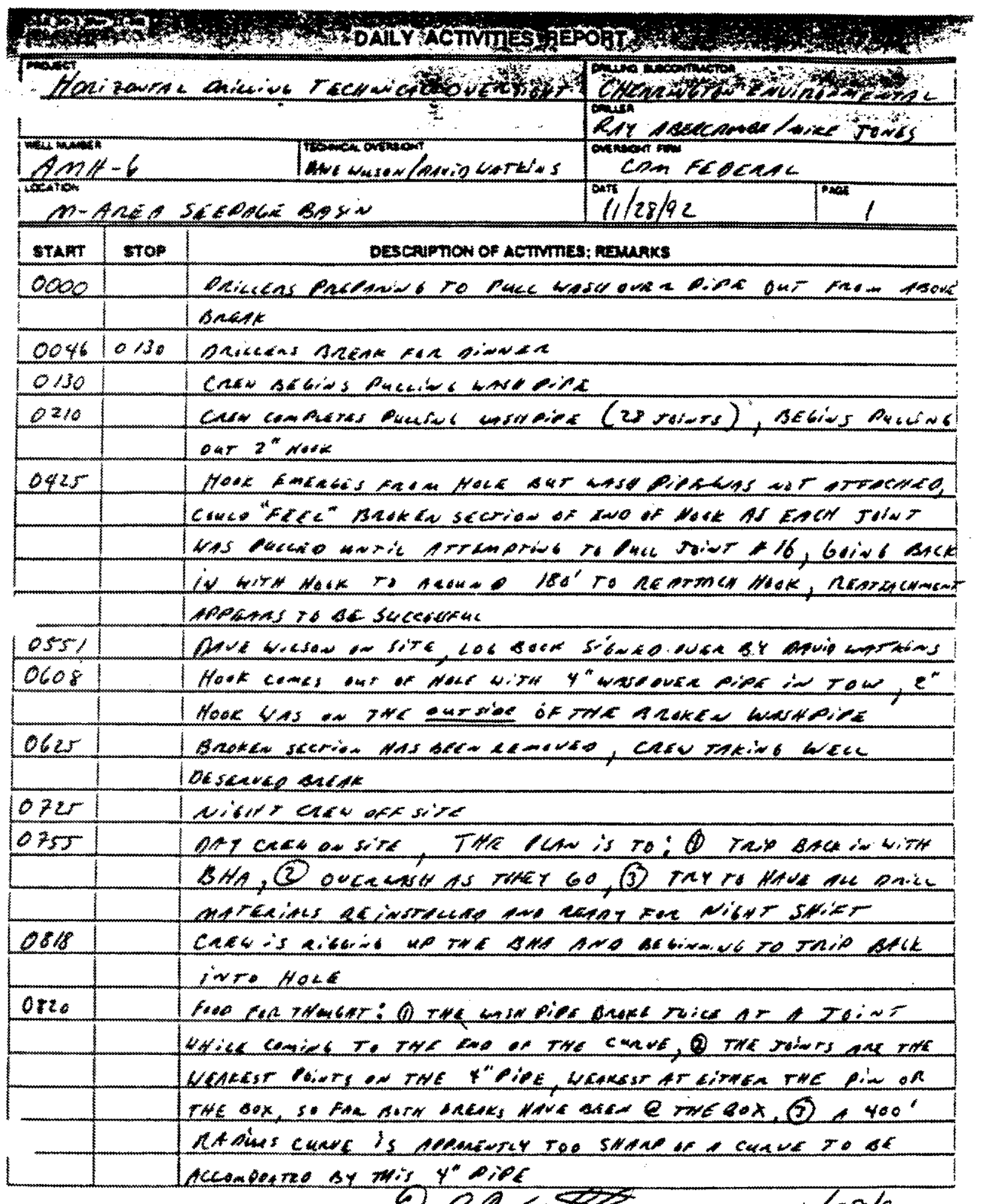

TECHNICA OVEASIOHT SIGNATURE 
Dexnonstration of River Crossing Technology for Installation of Einvironmental Horizontal Wells: AMH-6 and AMH-7 Installation Repon CDM Fecteral Programs Coxporation

Westinghouse Savannah River Company May 5, 1993

Subcontract No. AA46325P Task Order No. 10

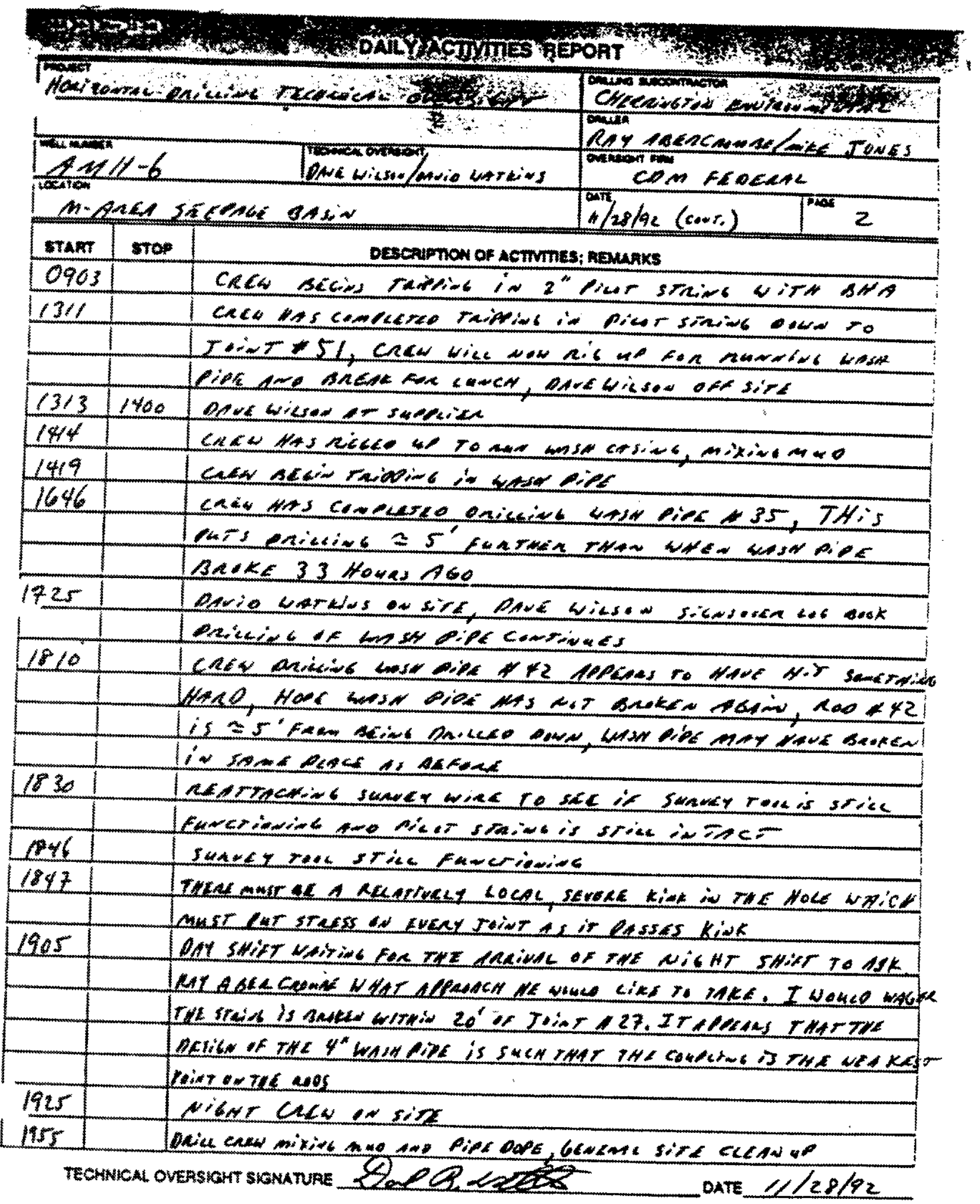

B-46 
Demonstration of River Crossing Technology for lastallation of Westinghouse Savannah River Company Eavironmental Horizontal Wells: AMH-6 and AMH-7 Installation Report COM Federal Programs Corporation

Subcontract No. AA46325P

May 5.1993

Task Order No. 10

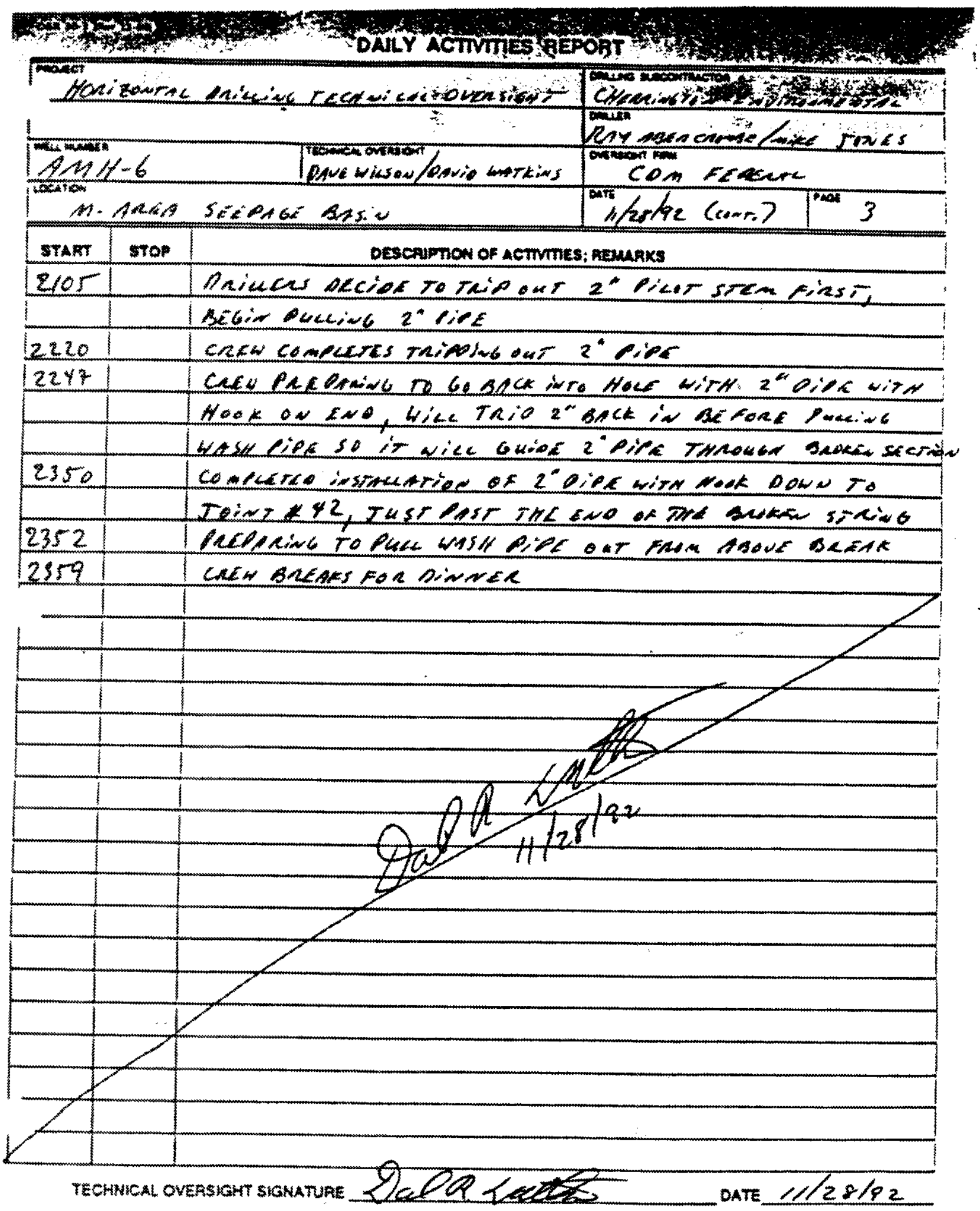


Demontration of River Crossing Technology for Installation of

EDvironmental Horizontal Wells: AMH-6 and AMH-7 lnstallation Repor

CDM Federal Programs Comporation

Westinghouse Savannah River Company May S, 1993

Subcontract No. AA46325P

Tesk Order No. 10

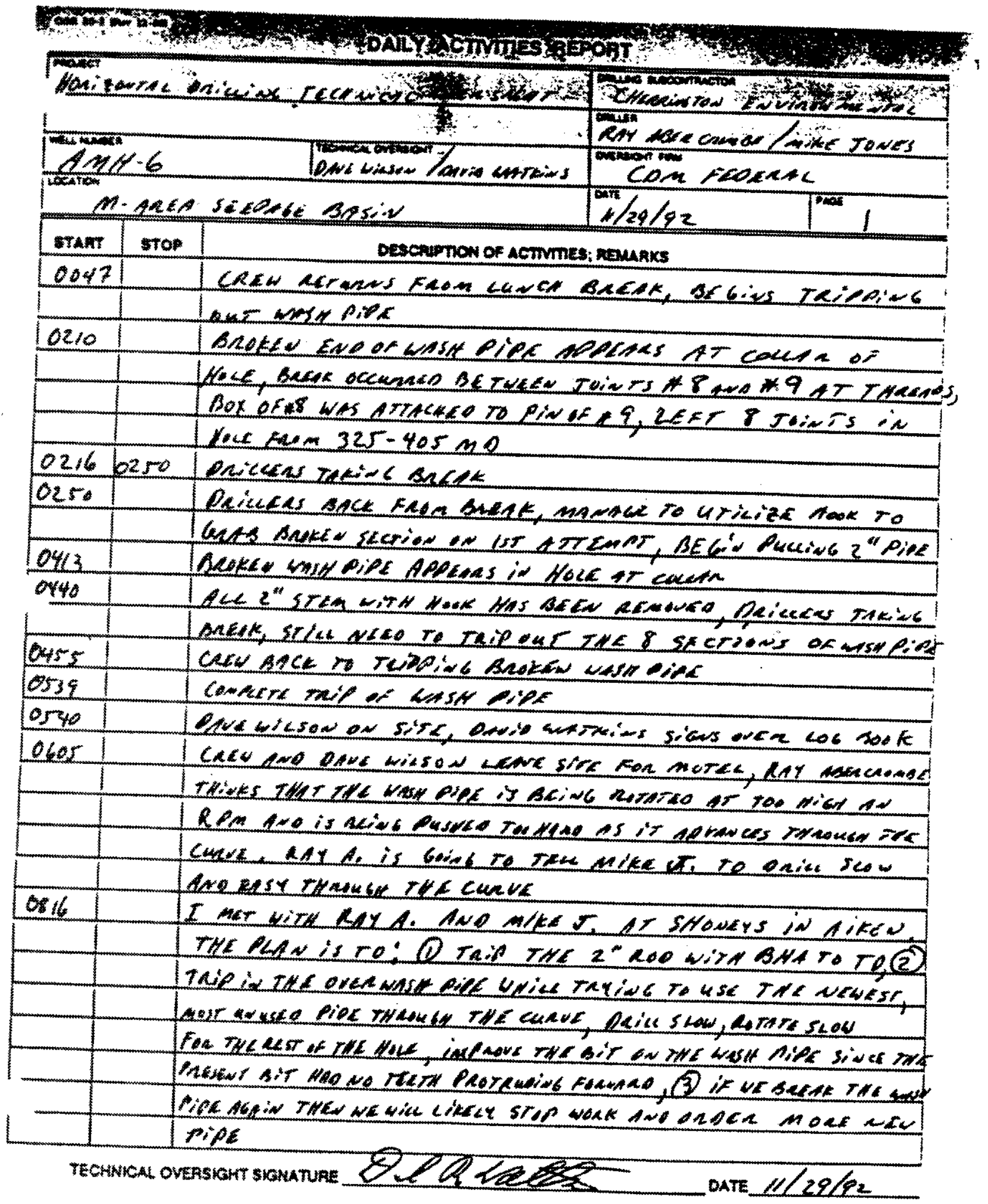


Demonstration of River Crossing Technology for Installation of Westinghouse Savannah River Company

Environmental Horizontal Wells: AMH-6 and AMH-7 Installation Report

CDM Federal Programs Corporation

Subcontract No. AA4632SP

May 5, 1993

Task Order No. 10

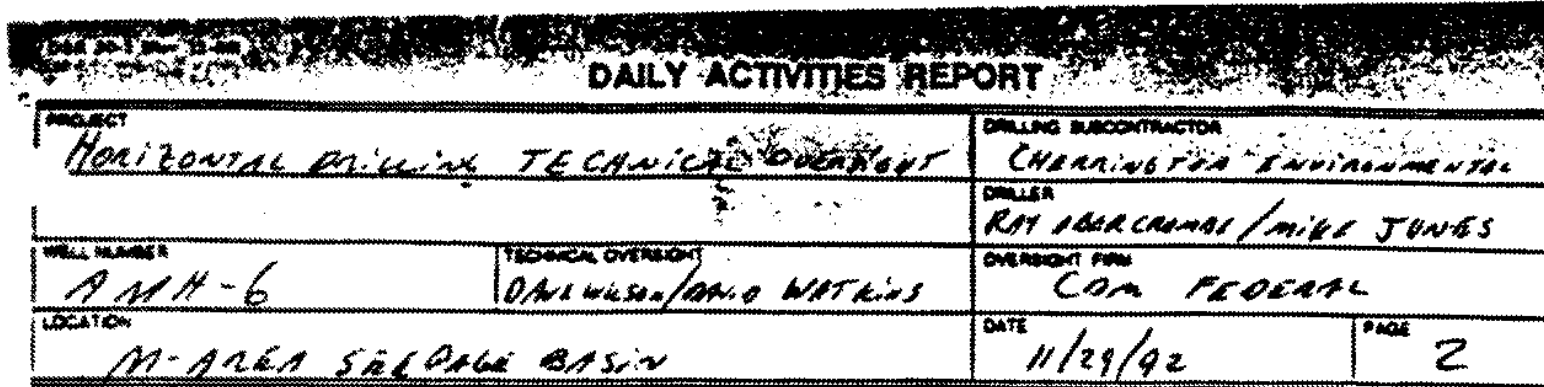

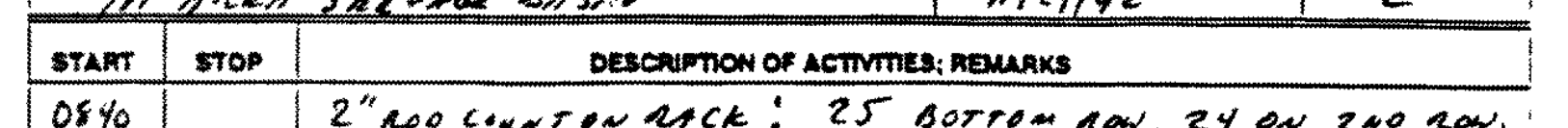

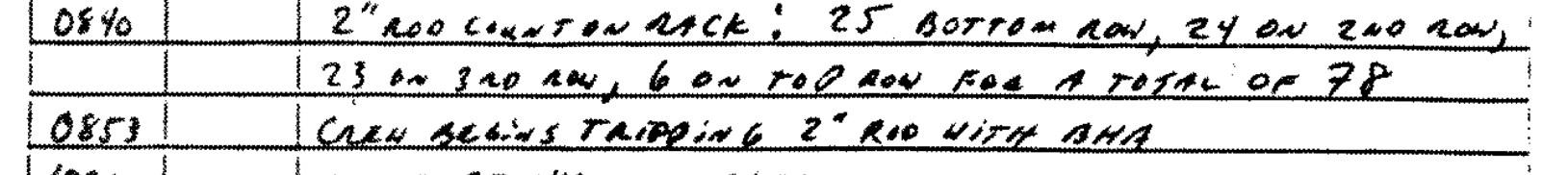

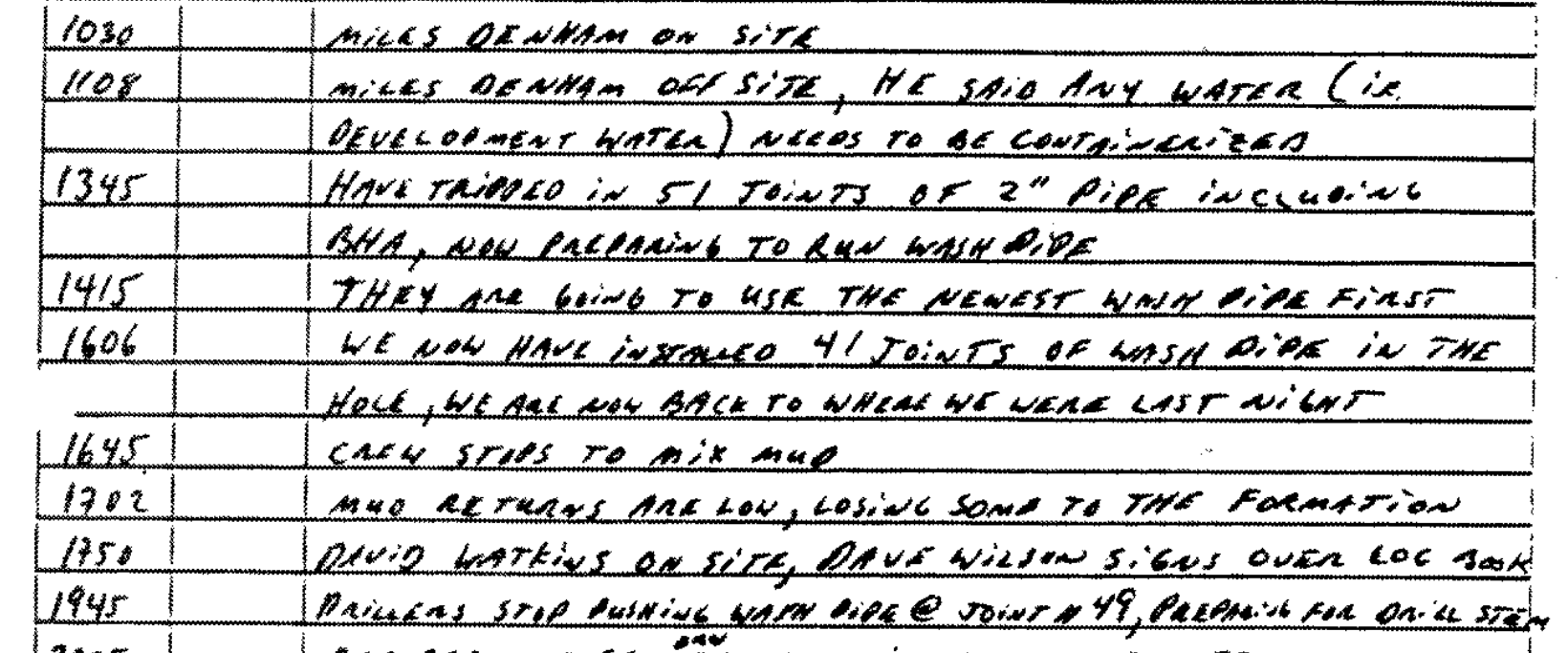

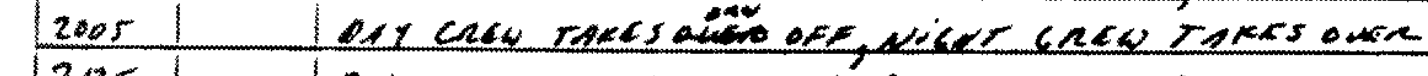

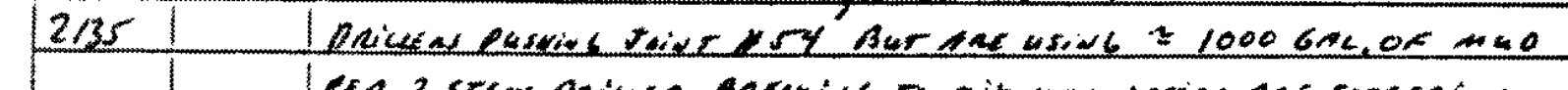

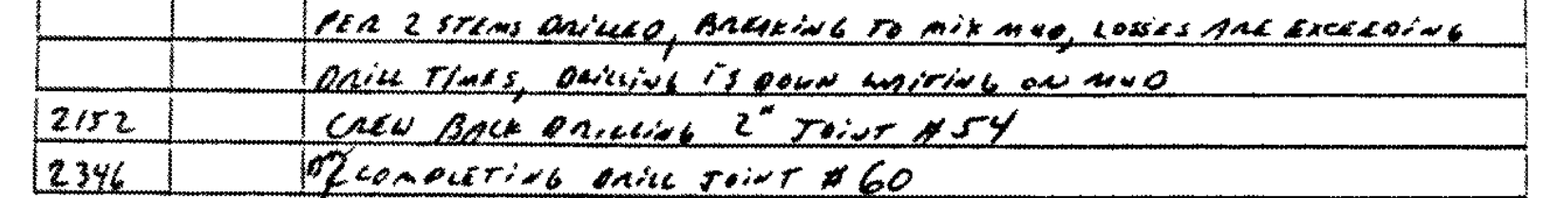

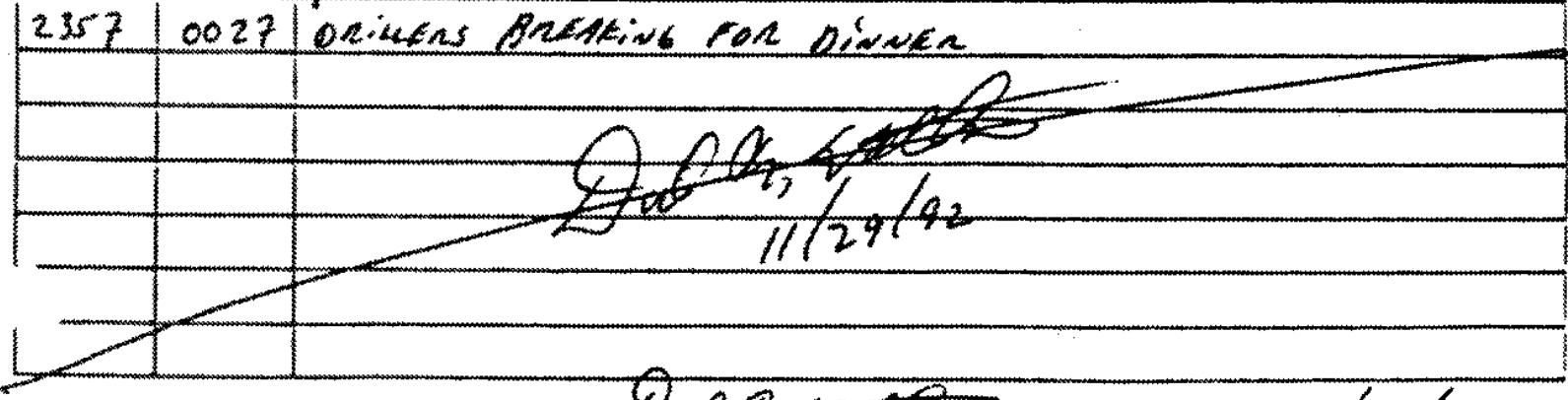

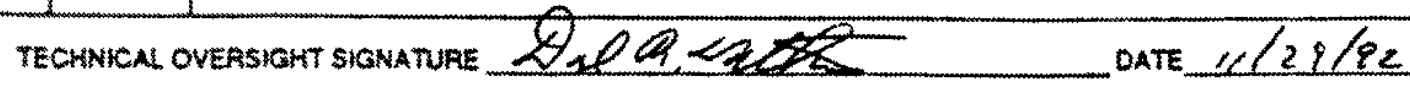


Demonstration of River Crossing Technology for Installation of Enviroamental Horizontal Wells: AMH-6 and AMH-7 Installation Report CDM Federal Programs Corporation May $\$, 1993$
Westinghouse Savannab River Company Subcontract No. AA46325P

Task Order No. 10

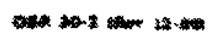

DALY ACTIVIES REPOAT

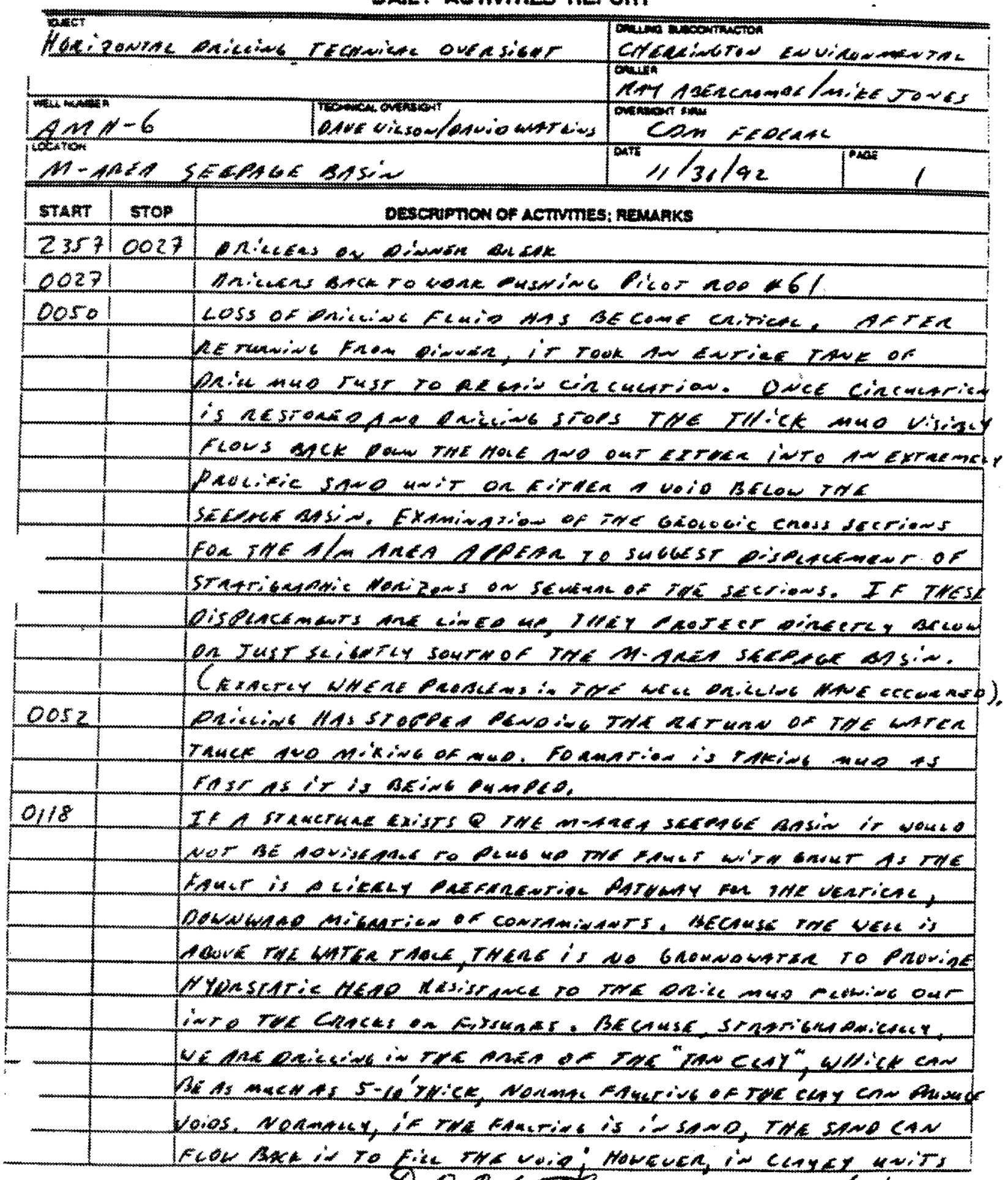

TEOWCAL OVESIGHT SIGNATURE 8) 0.2025 Dare $n / 30 / 92$ 
Demonstration of River Crossing Technology for Installation of Environmental Horizontal Wells: AMH -6 and AMH-7 Installation Report CDM Federal Programs Corporation May 5.1993
Westinghouse Savannah River Company Subcontract No. AA46325P Task Order No. 10

1*a.

DALIY ACTVITES REPORT

\begin{tabular}{|c|c|c|}
\hline \multicolumn{2}{|c|}{ Hanizeres } & 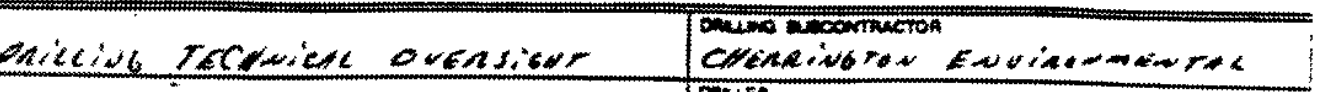 \\
\hline \\
\hline \multirow{2}{*}{\multicolumn{2}{|c|}{ 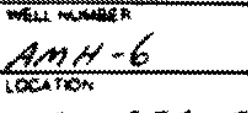 }} & 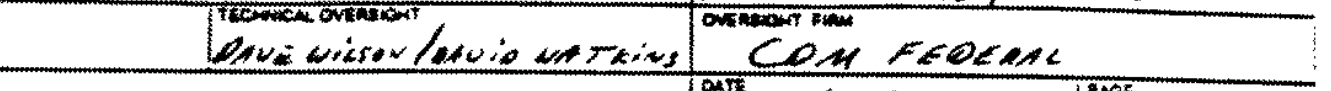 \\
\hline & 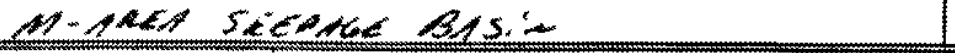 & 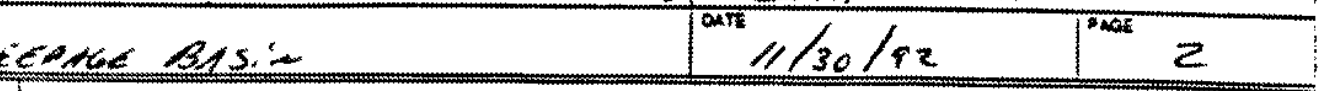 \\
\hline \multirow{2}{*}{$\frac{S T A R T}{C H A C G O}$} & stop & DESCRUPTION OF ACTVMES; REMAAKS \\
\hline & & 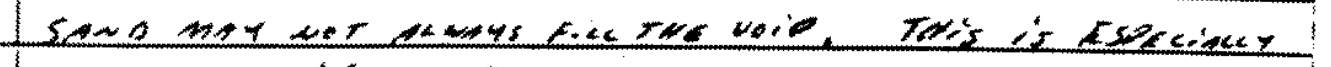 \\
\hline \multirow{2}{*}{$\frac{1}{1}$} & & 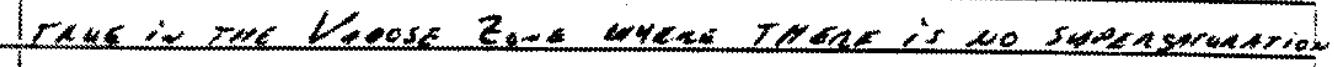 \\
\hline & & 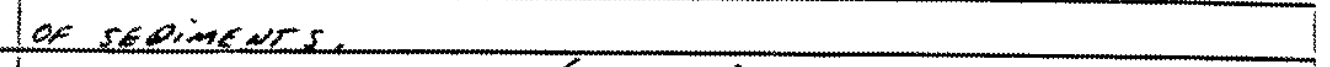 \\
\hline \multirow[t]{4}{*}{0,43} & & 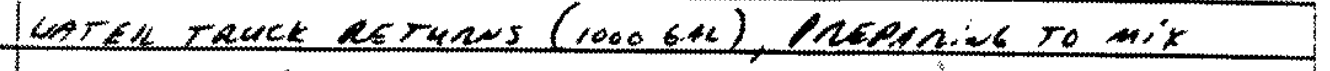 \\
\hline & & 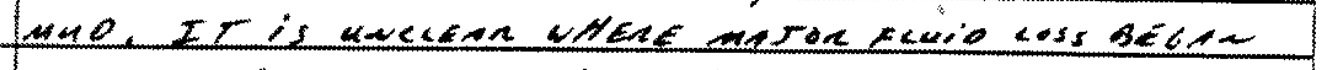 \\
\hline & & 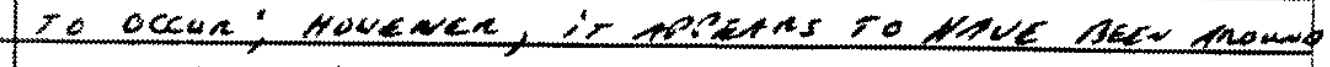 \\
\hline & & 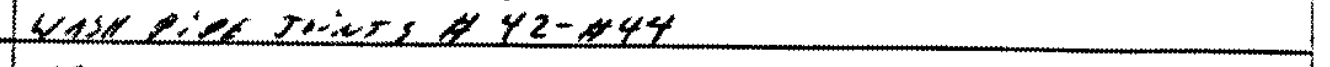 \\
\hline \multirow[t]{8}{*}{0,51} & & 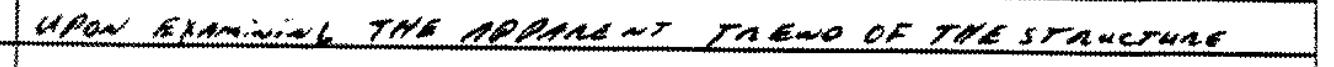 \\
\hline & & 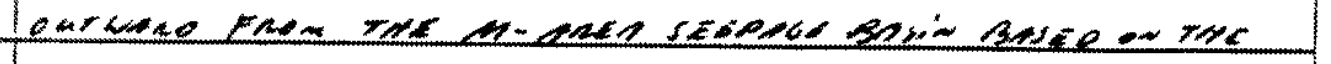 \\
\hline & & 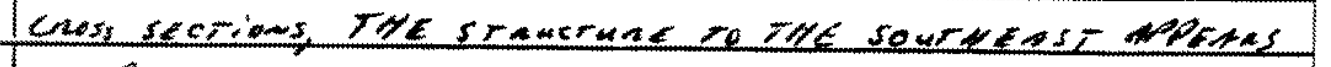 \\
\hline & & 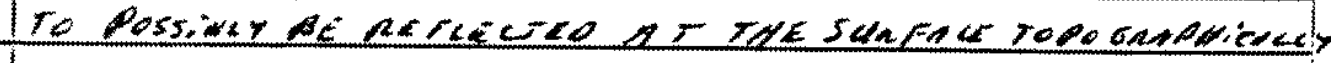 \\
\hline & & 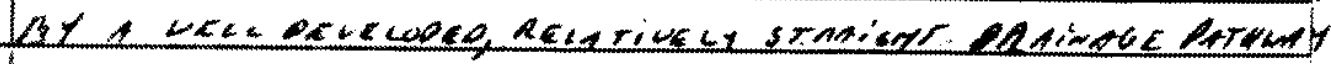 \\
\hline & & 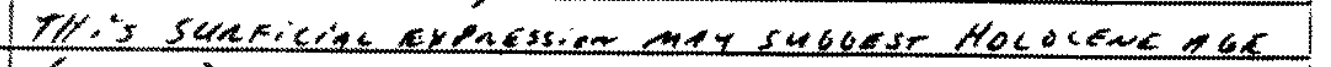 \\
\hline & & 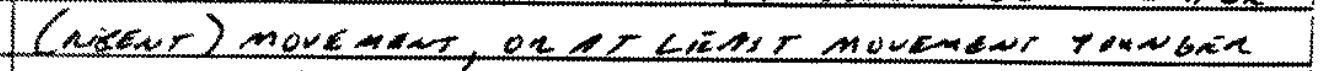 \\
\hline & & 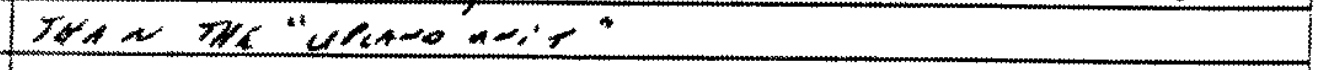 \\
\hline \multirow[t]{2}{*}{0210} & & 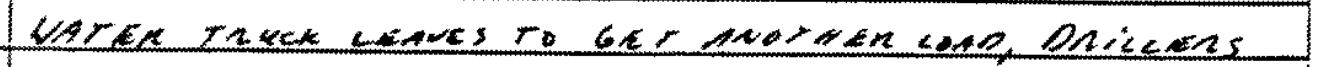 \\
\hline & & mikite mue \\
\hline \multirow[t]{2}{*}{0240} & & 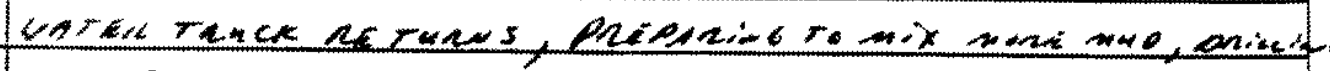 \\
\hline & & 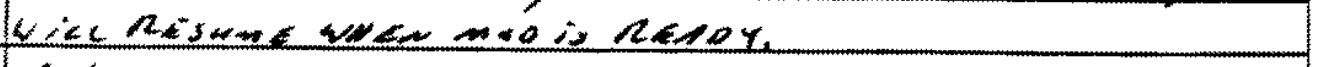 \\
\hline \multirow[t]{4}{*}{0306} & & 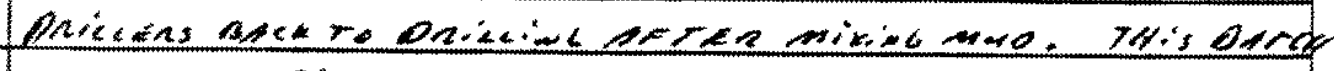 \\
\hline & & 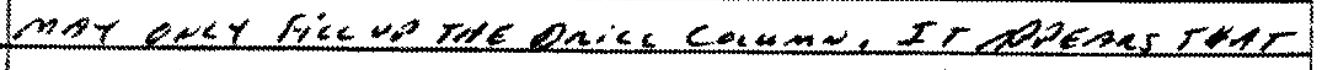 \\
\hline & & 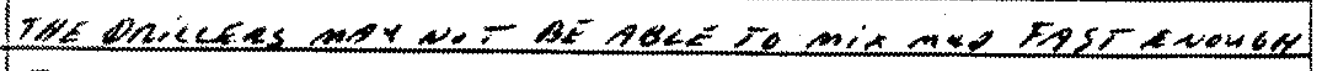 \\
\hline & & To keeP un wirn LOS5ES. \\
\hline \multirow{2}{*}{$\frac{0325}{0337}$} & & weren Takekneranes (1000 bed) \\
\hline & & 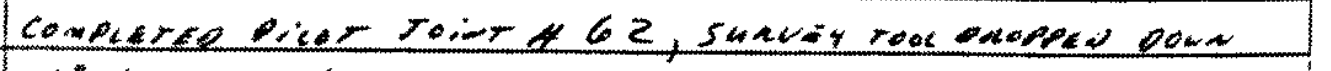 \\
\hline \multirow{3}{*}{0337} & & 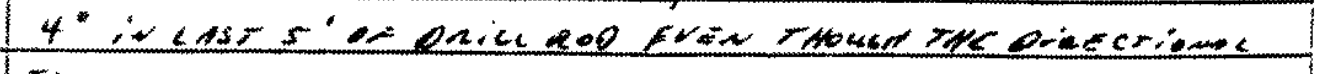 \\
\hline & & 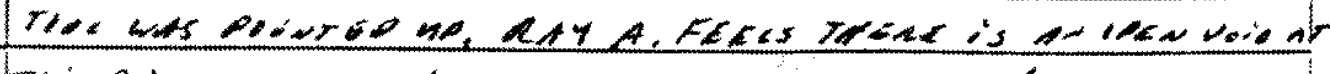 \\
\hline & & 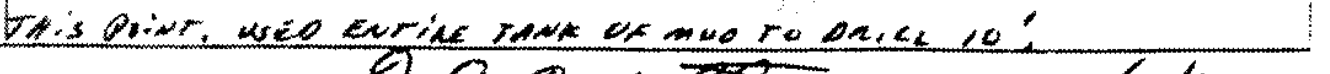 \\
\hline
\end{tabular}


Demonstration of River Crossing Technology for Installation of Environmental Horizontal Wells: AMH-6 and AMH-7 Installation Report CDM Federal Programs Corporation

Westinghouse Savannah River Company May 5.1993

Subcontract No. AA46325P

Task Onder No. 10

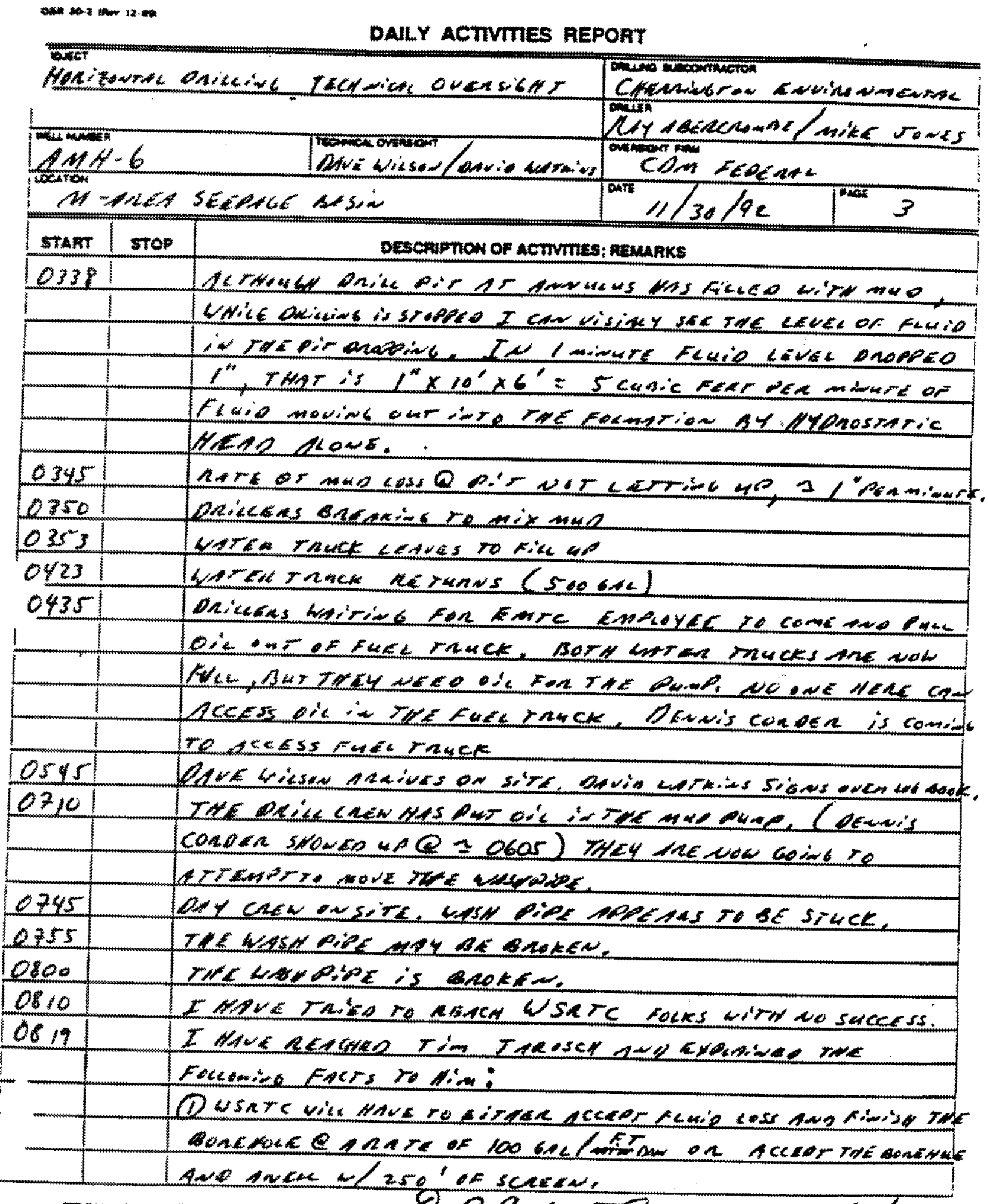

TEOWICAL OVEASWOHT SICNATUAE C) $P Q+2$ DATE $11 / 20 / 92$ 
Demonstration of River Crossing Technology for Installation of Environmental Horizontal Wells: AMH-6 and AMH-7 Installation Report CDM Federal Programs Corporation

May 5,1993
Westinghouse Savannah River Company Subcontract No. AA46325P Task Order No. 10

ata.

\section{DALIY ACTVITES REPORT}

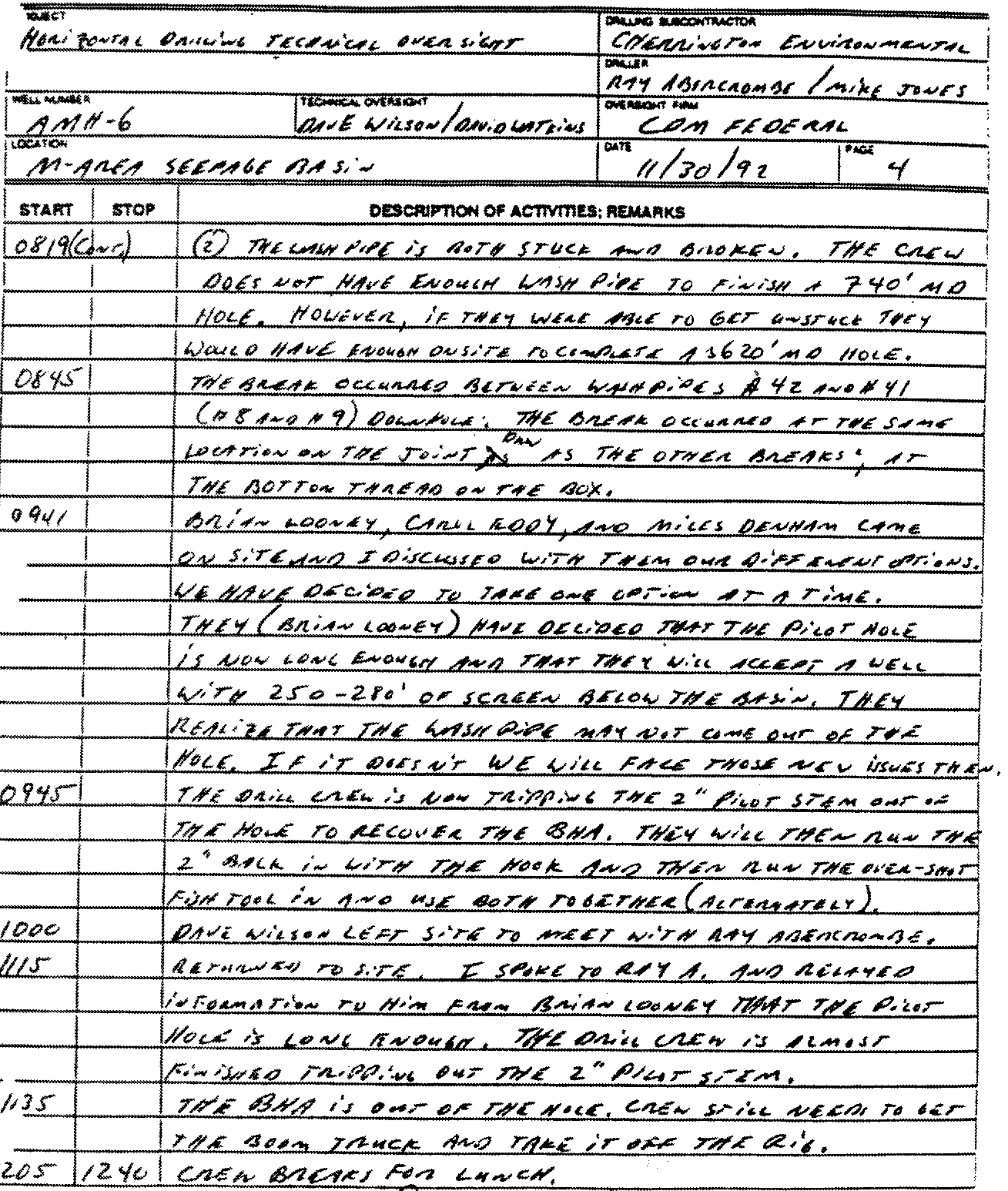

TECHNICAL OVEASIGHT SIGNATURE QneQRers DATE $11 / 30 / 92$ 
Demoustration of River Crossing Technology for Installation of Einviromental Horizontal Wells: AMH-6 and AMH-7 Installation Report COM Fecteral Programs Corporation May \$. 1993
Westinghouse Savamah River Company Subcontract No. AA46325P Task Onder No. 10

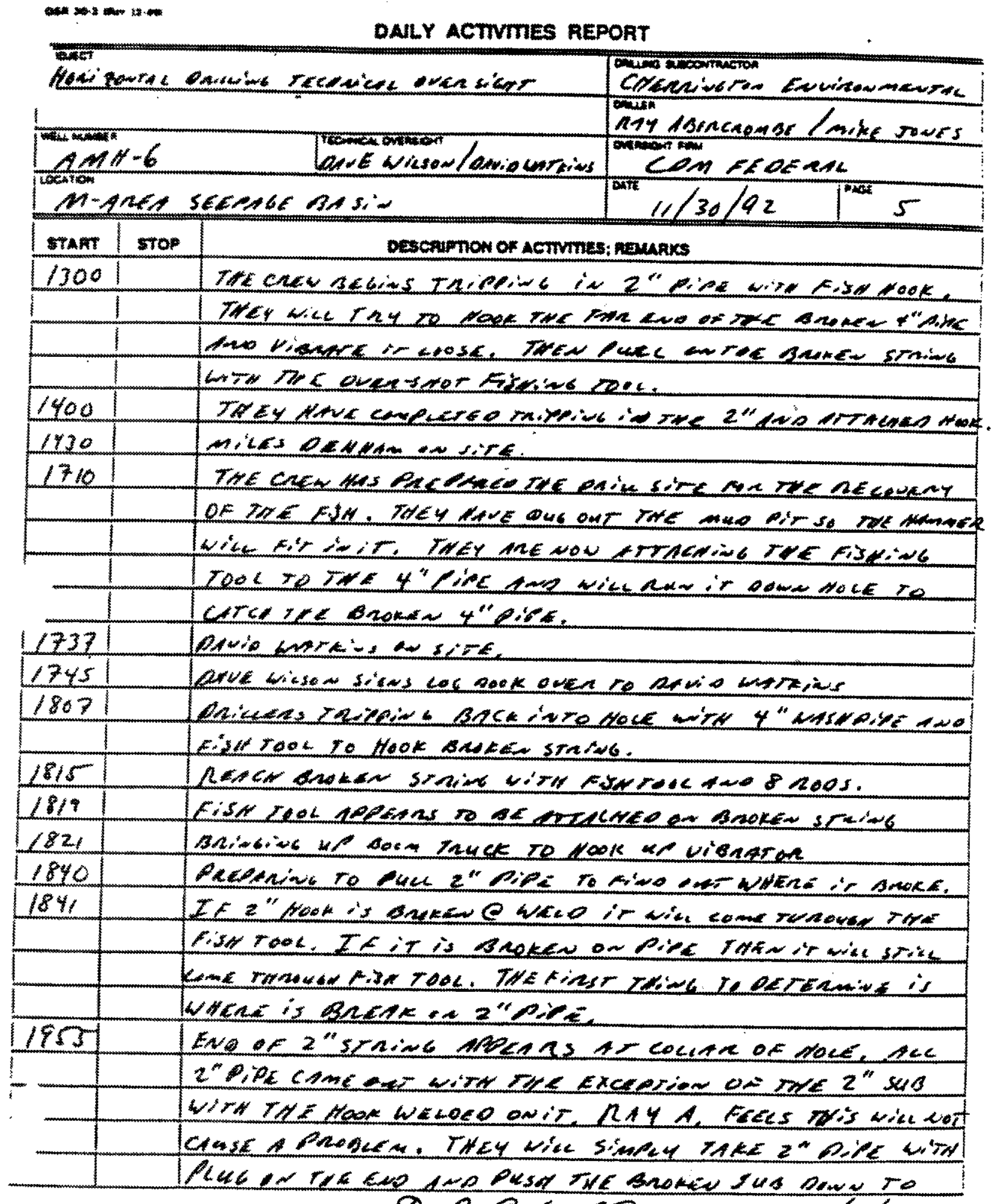

TECHNICAL OVEASICHT SIGNATUAE Q) $R+20$ DATE $1 / 1 / 3 / 92$ 
Demonstration of River Crossing Technology for Installation of Environmental Horizontal Wells: AMH-6 and AMH-7 Installation Repor CDM Fecteral Programs Corporation

May 5,1993
Westinghouse Savannah River Company Subcontract No. AA46325P

Task Order No. 10

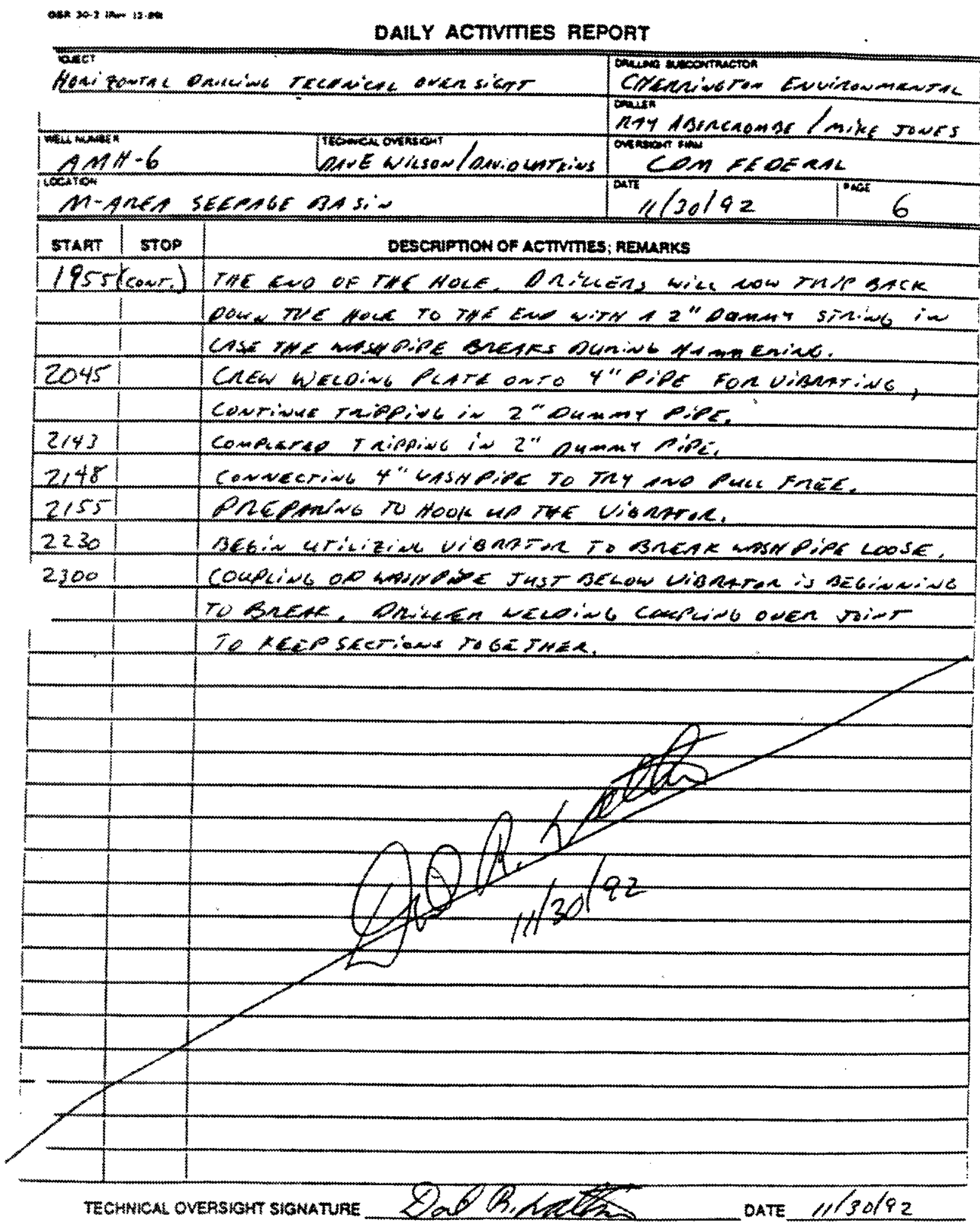


Demonstration of River Crossing Technology for Installation of Eavironmental Horizontal Wells: AMH-6 and AMHA-7 Installation Report CDM Federal Programs Corporation

Westinghouse Savannah River Company May 5,1993

Subcontract No. AA46325P

Task Order No. 10

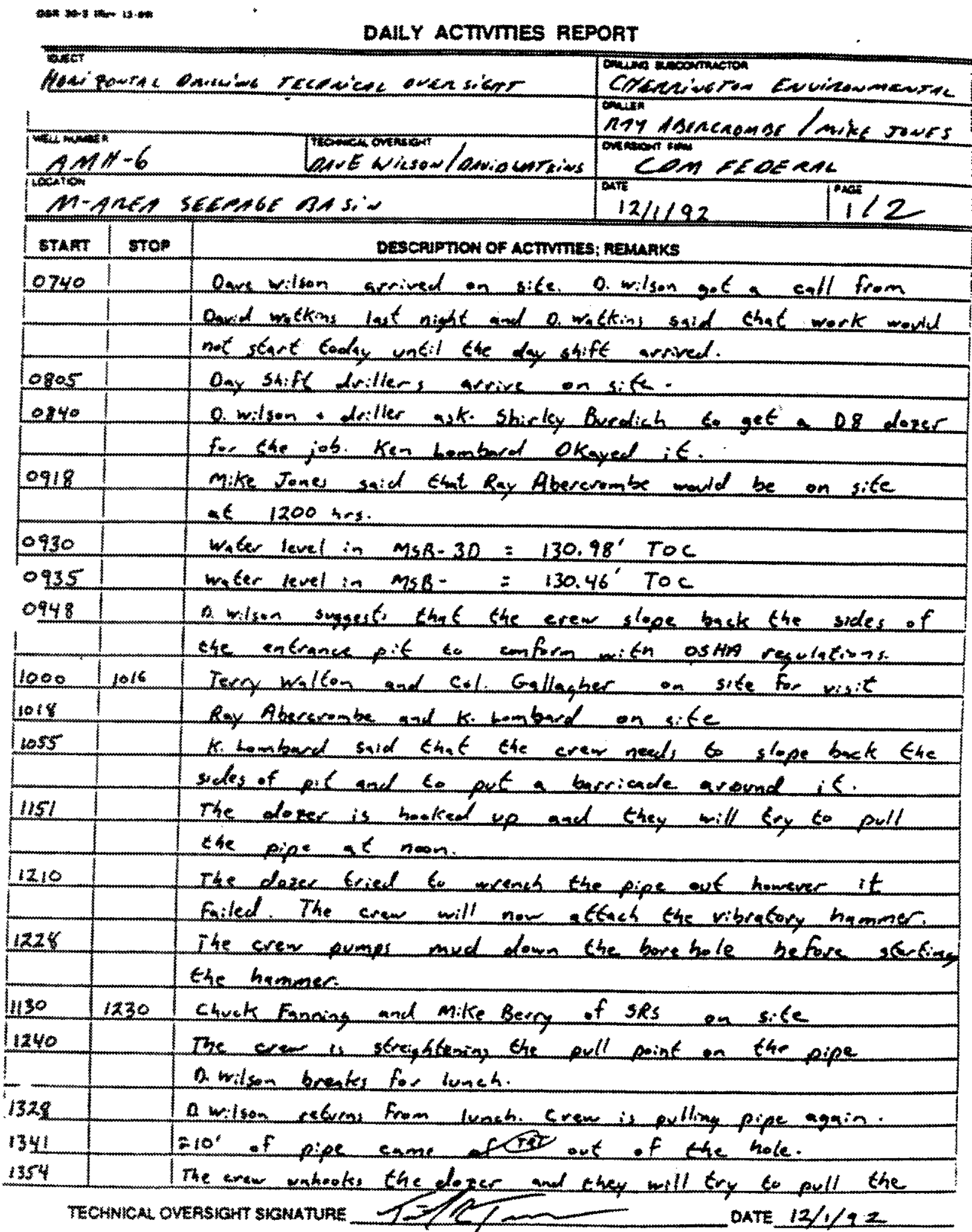


Demonstration of River Crossing Tectnology for Installation of Environusental Horizontal Wells: AMH-6 and AMH-7 Installation Report CDM Fecteral Programs Corporation

May 5,1993
Westinghouse Savannah River Company Subcontract No. AA46325P Task Order No. 10

\section{-}

\section{DALYY ACTIVTIES REPORT}

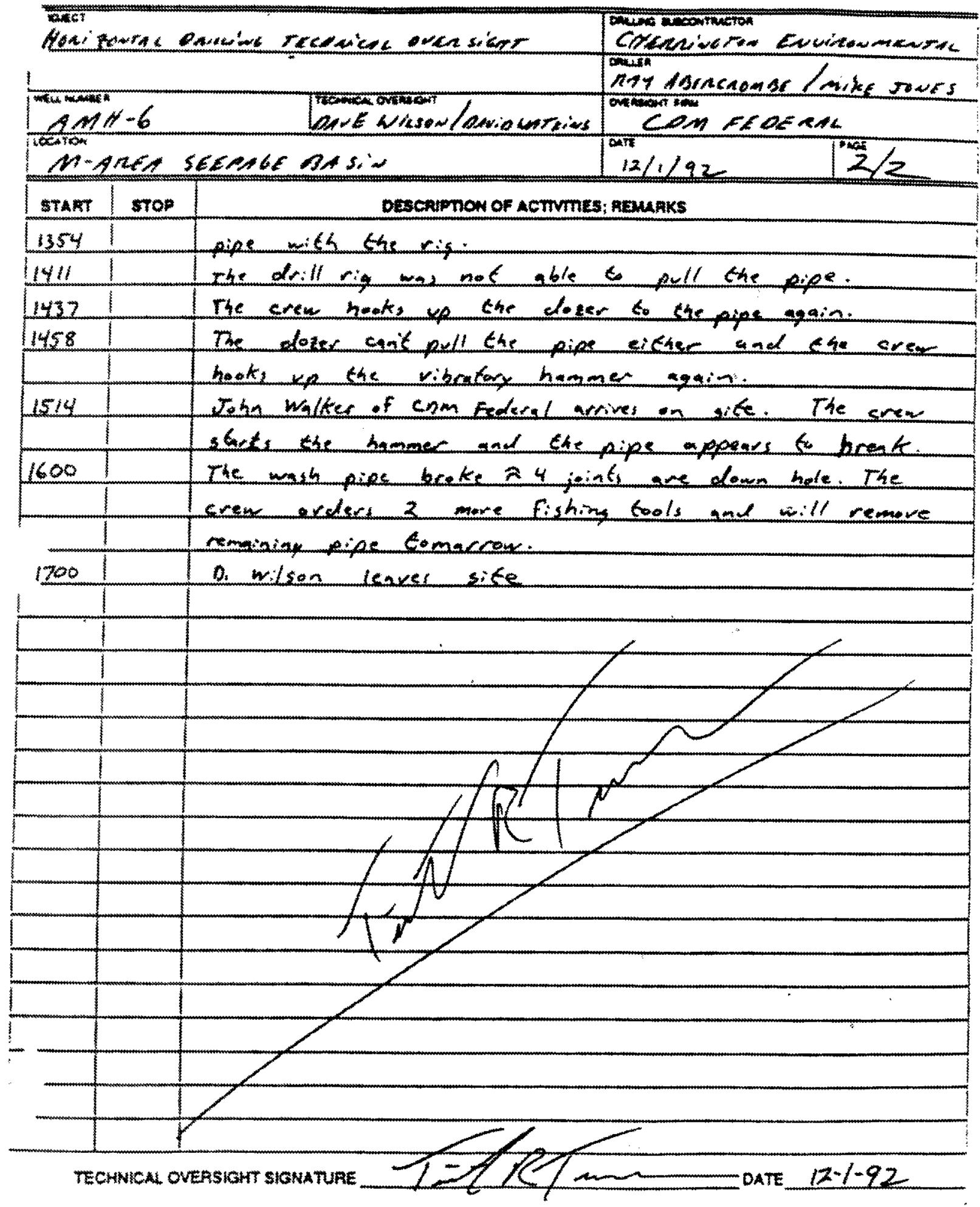


Demowstration of River Crossing Technology for Installation of Environmevtal Horizontal Wells: AMH-6 and AMH-7 Installation Report CDM Federal Programs Corporation

Westinghouse Savannah River Company May 5,1993

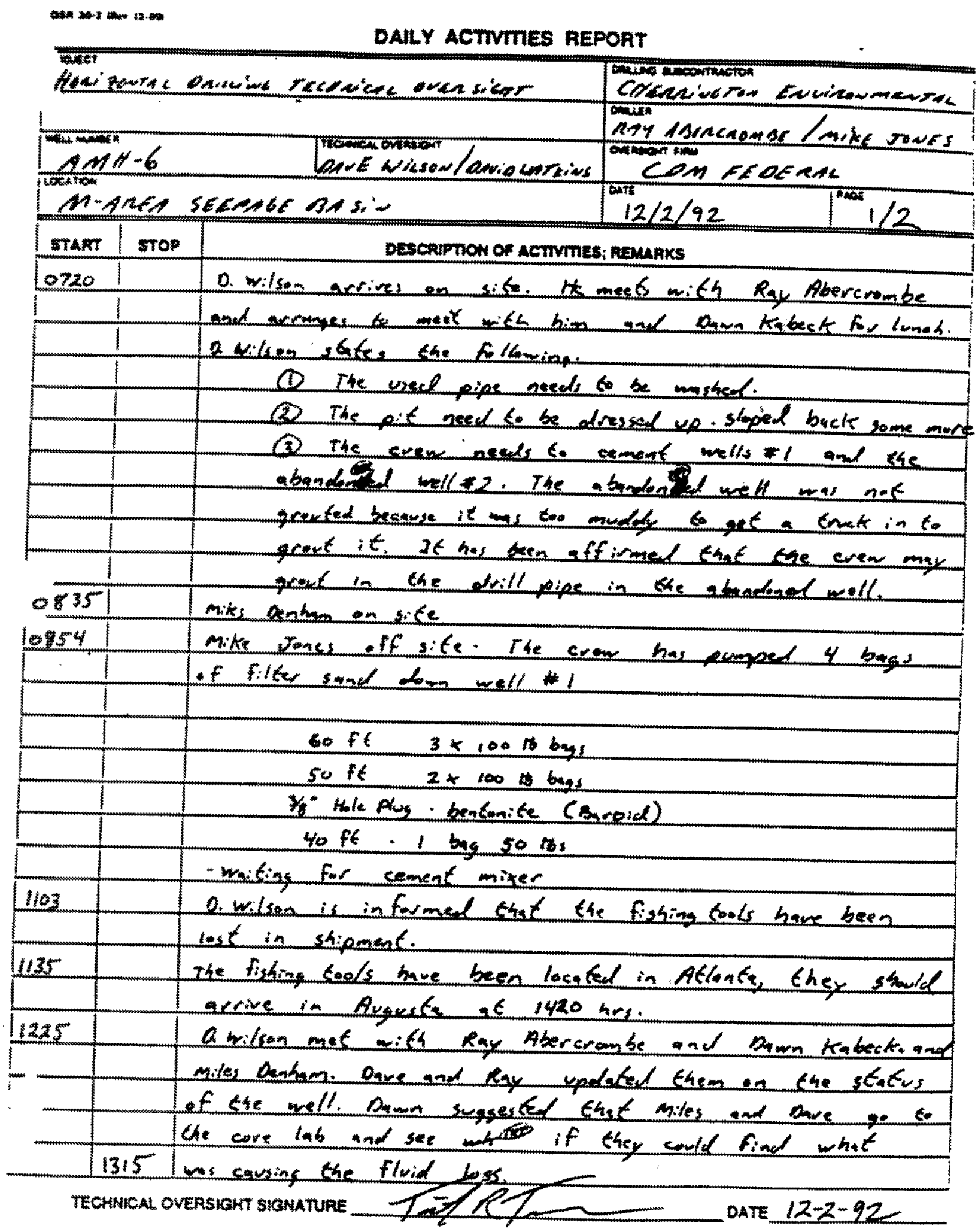


Demonstration of River Crossing Technology for Installation of

Environmental horizontal Wells: AMH-6 and AMH-7 Installation Report CDM Federal Programs Comporation

May 5.1993
Westinghouse Savannah River Company Subcontract No. AA46325P Task Order No. 10

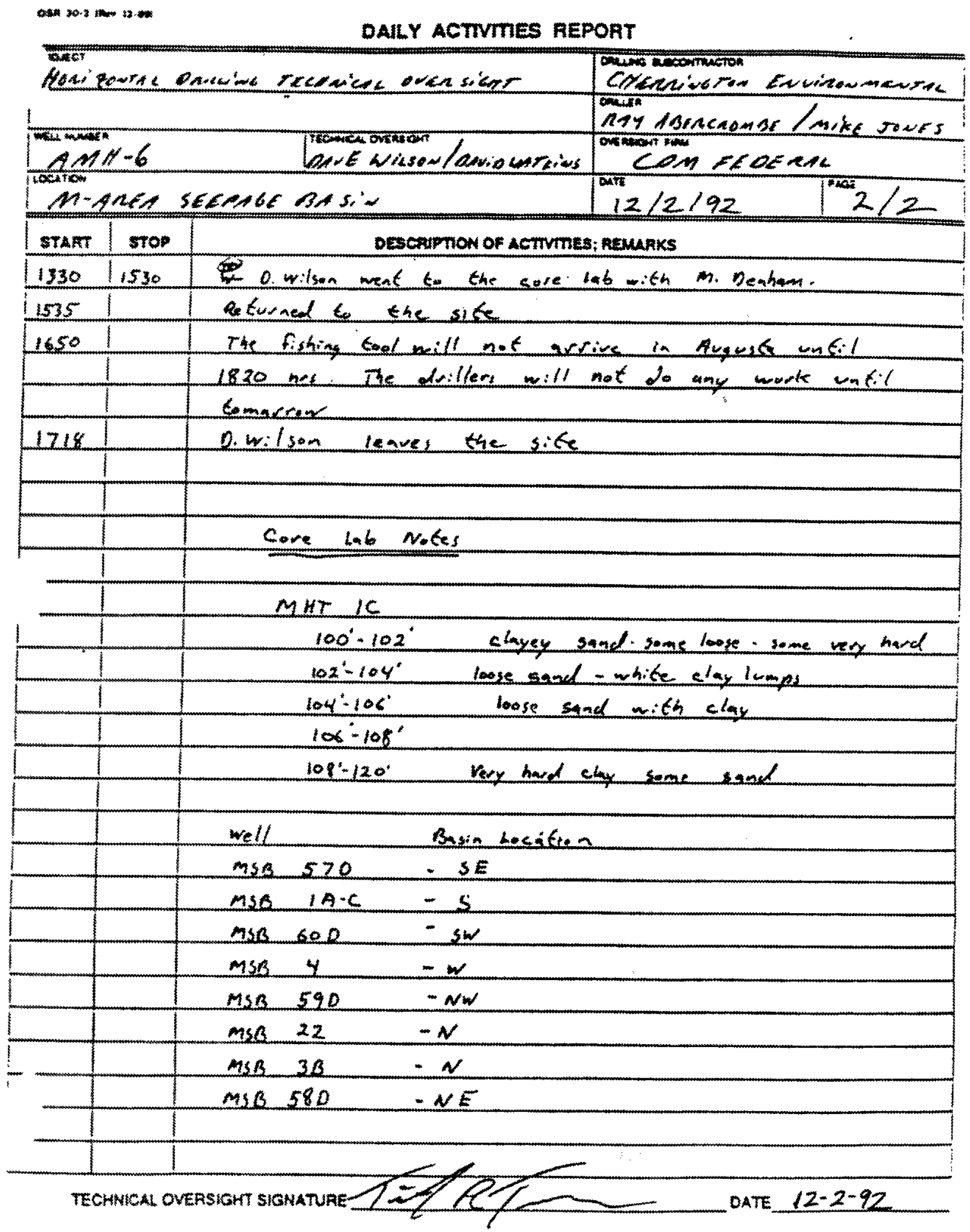


Demonstration of River Crossing Technology for Installation of Eavironmental Horizontal Wells: AMH-6 and AMH-7 Installation Report CDM Federal Programs Corporation

May $\$, 1993$
Westinghouse Savannah River Company Subcontract No. AA46325P

Task Order No. 10

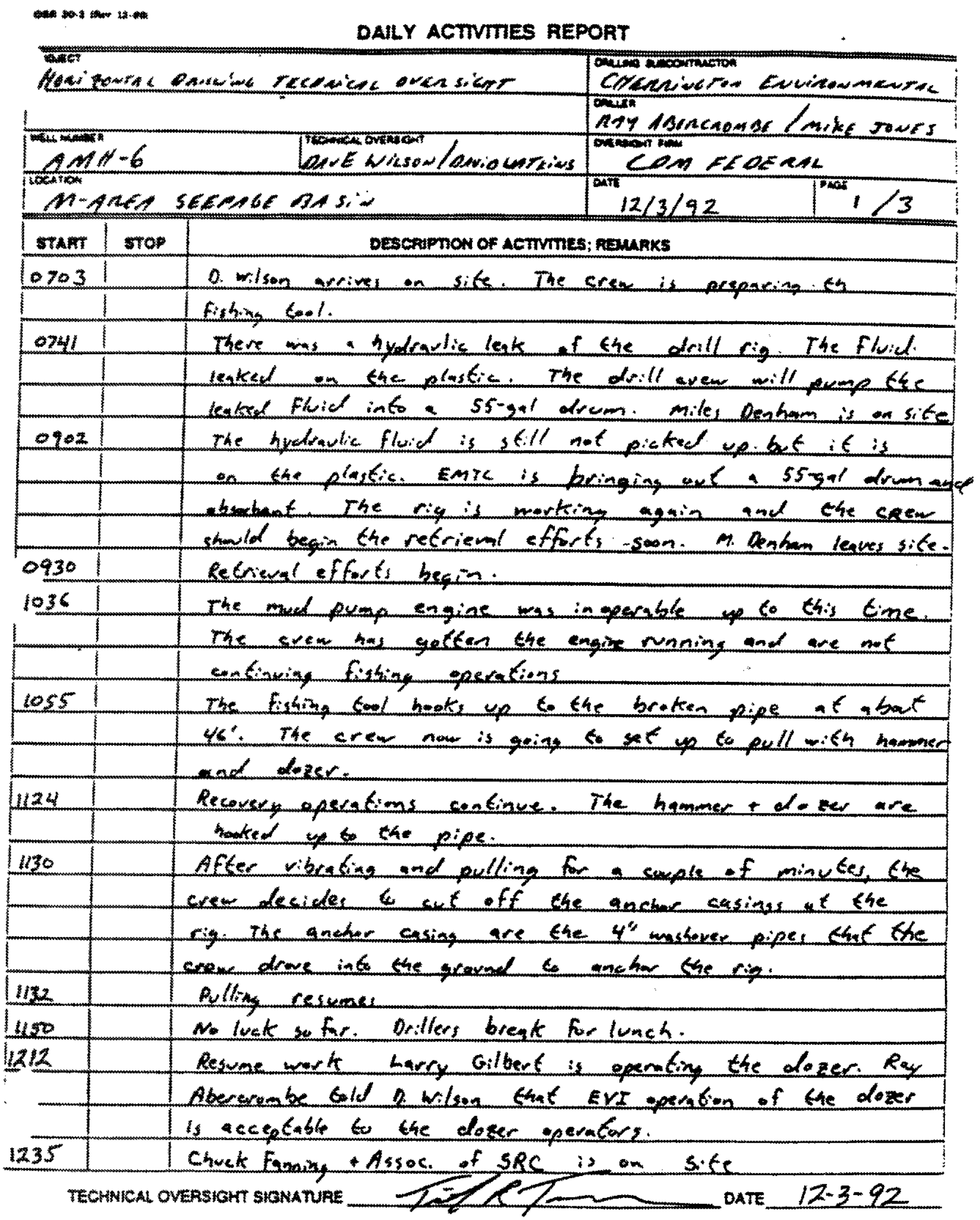

B-60 
Demonstration of River Crossing Technology for Installation of Westinghouse Savannah River Company Environmental Horizontal Wells: AMH-6 and AMH-7 Installation Report CDM Federal Programs Corporation

Subcontract No. AA46325P

May \$. 1993

Task Order No. 10

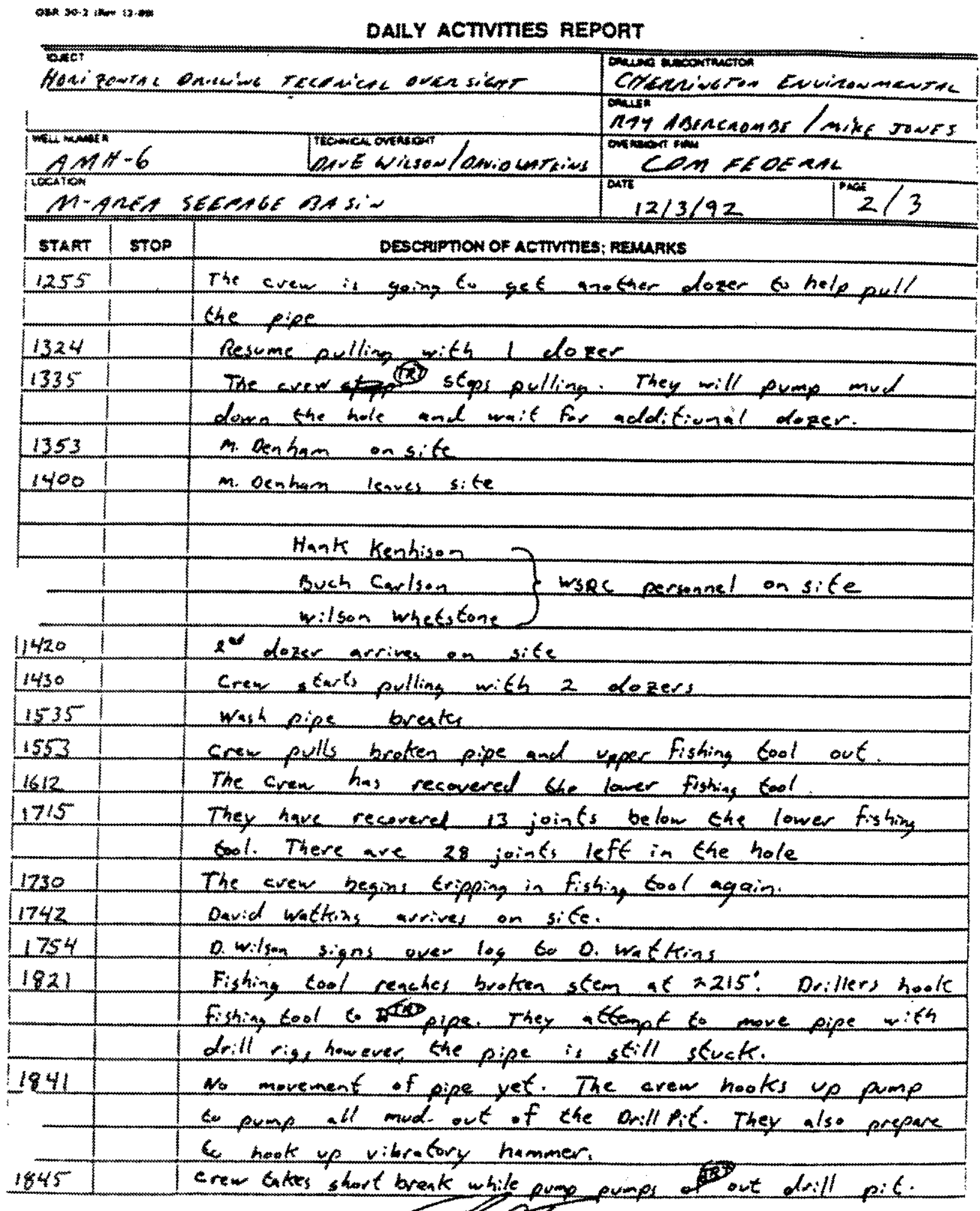

TECHNICAL OVERSIGHT SIGNATURE

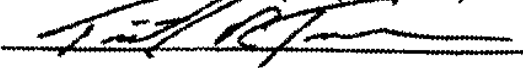
OATE $\quad 12-3-92$ 
Demonstration of River Crossing Technology for Installation of Environamental Horizontal Wells: AMH-6 and AMH-7 lostallation Report COM Federal Programs Corporation

May 5.1993
Westinghouse Savannah River Company Subcontract No. AA46325P

Task Order No. 10

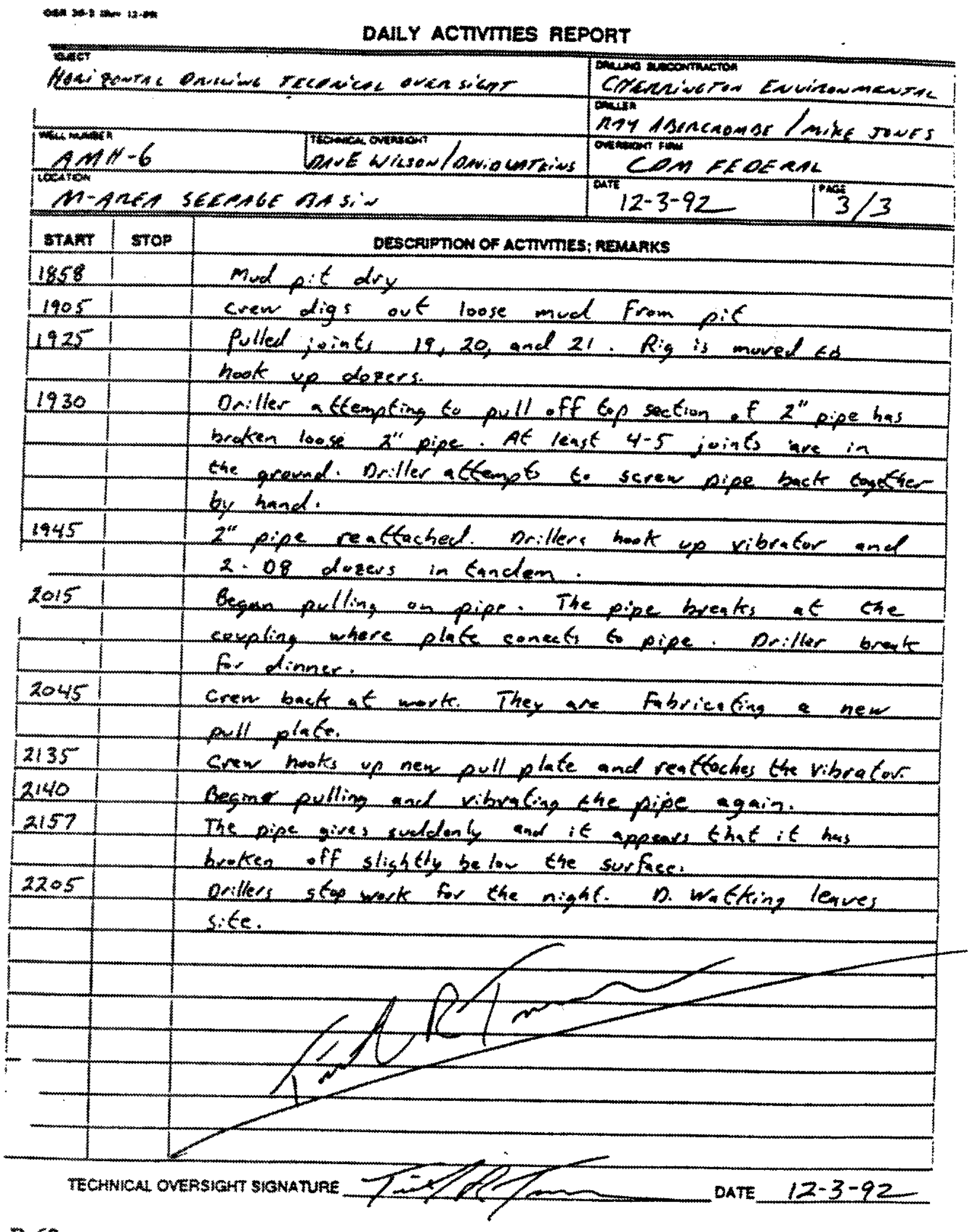

$B-62$ 
Dexwonstration of River Crossing Technology for Installation of Environmental Horizontal Wells: AMH-6 and AMH-7 Installation Report CDM Federal Programs Corporation

May $\$, 1993$
Westinghouse Savannah River Company Subcontract No. AA46325P

Task Order No. 10

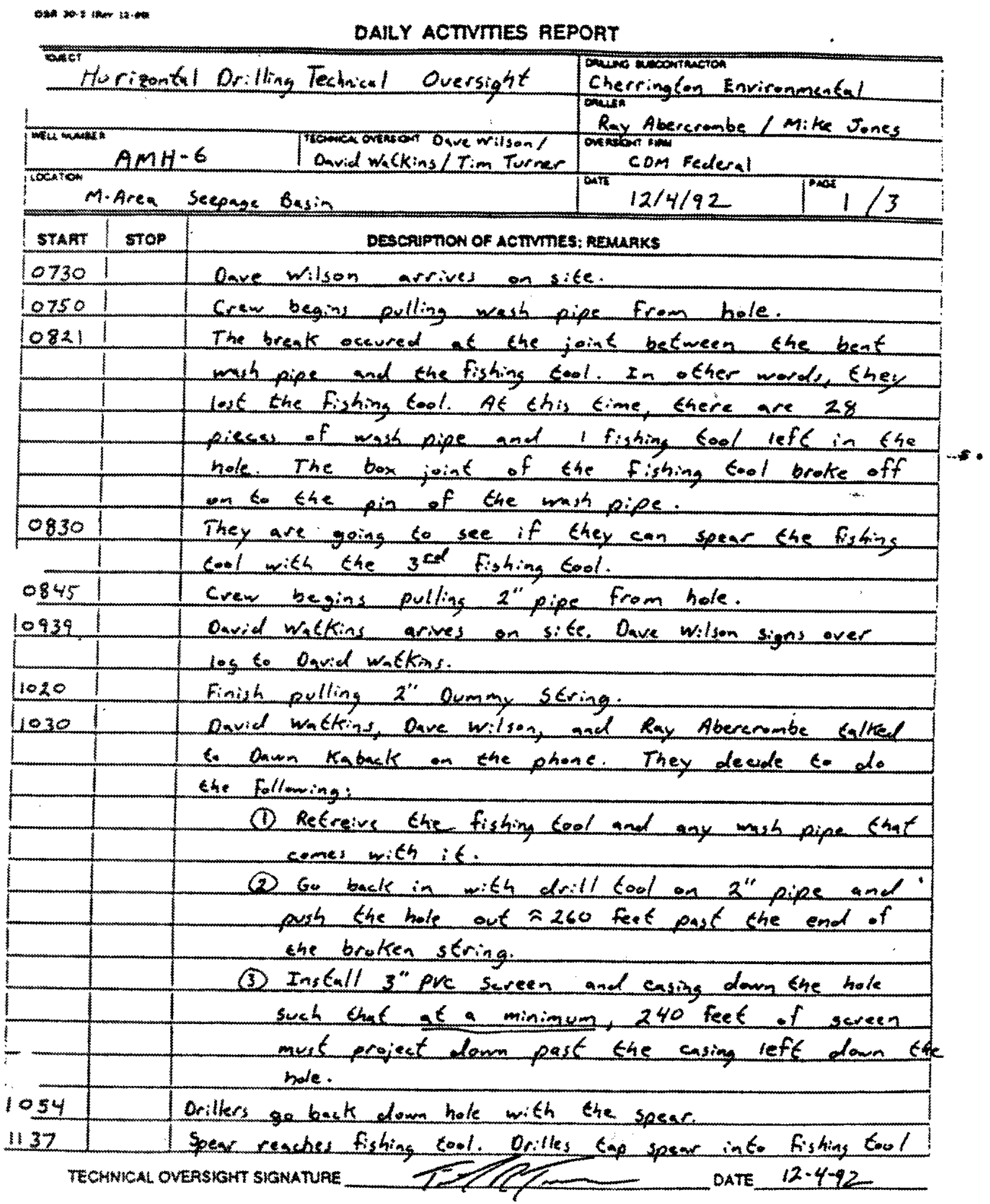


Dewonstration of River Crossing Technology for Installation of Westinghouse Savannah River Company Environmental Horizontal Wells: AMH-6 and AMH-7 Installation Report CDM Federal Programs Corporation

Subcontract No. AA46325P

May 5, 1993

Task Order No. 10

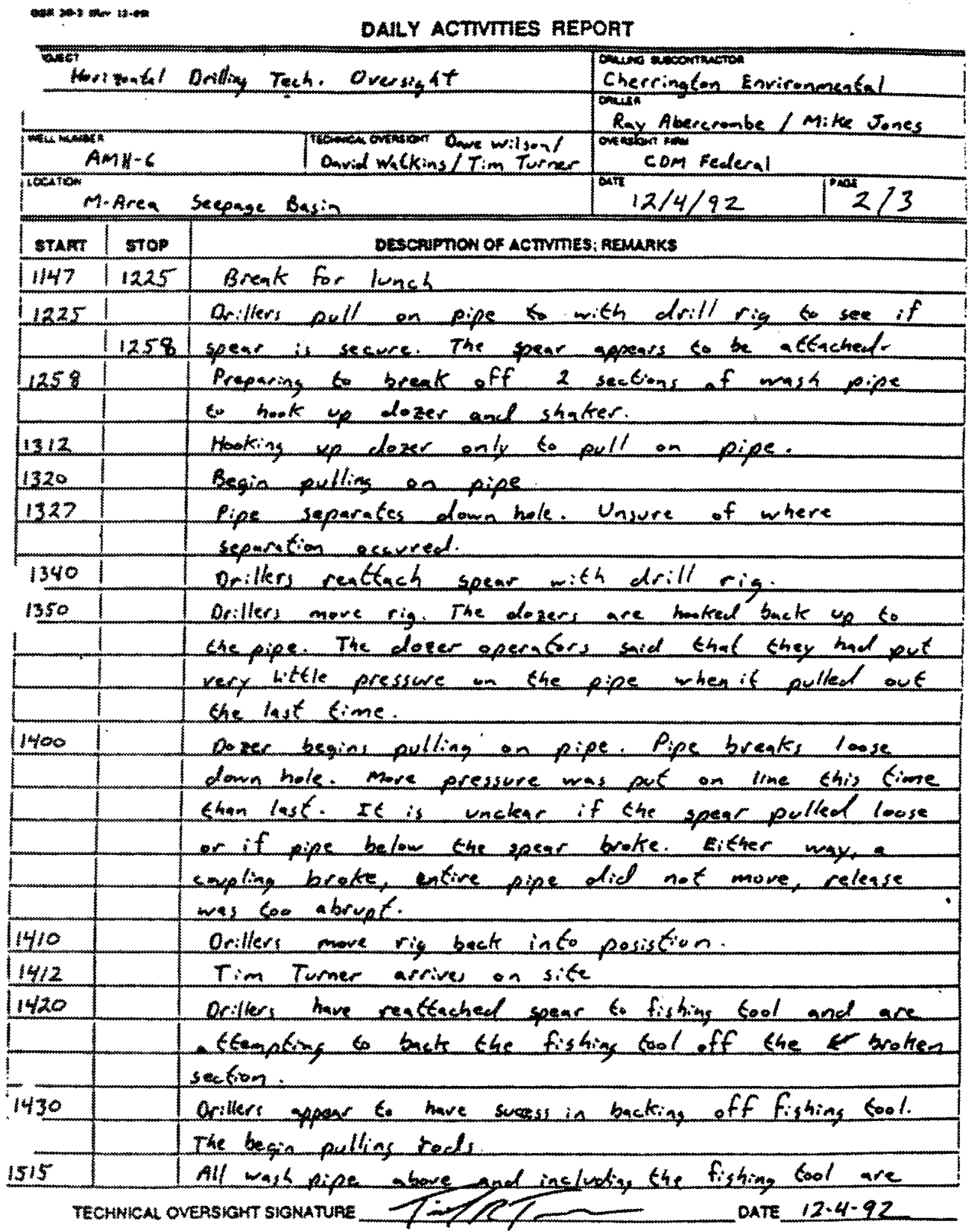

B-64 
Demonstration of River Crossing Technology for Installation of Environmental Horizontal Wells: AMH-6 and AMH-7 Installation Report CDM Federal Programs Corporation

May 5,1993
Westinghouse Savannah River Company

Subcontract No. AA46325P

Task Order No. 10

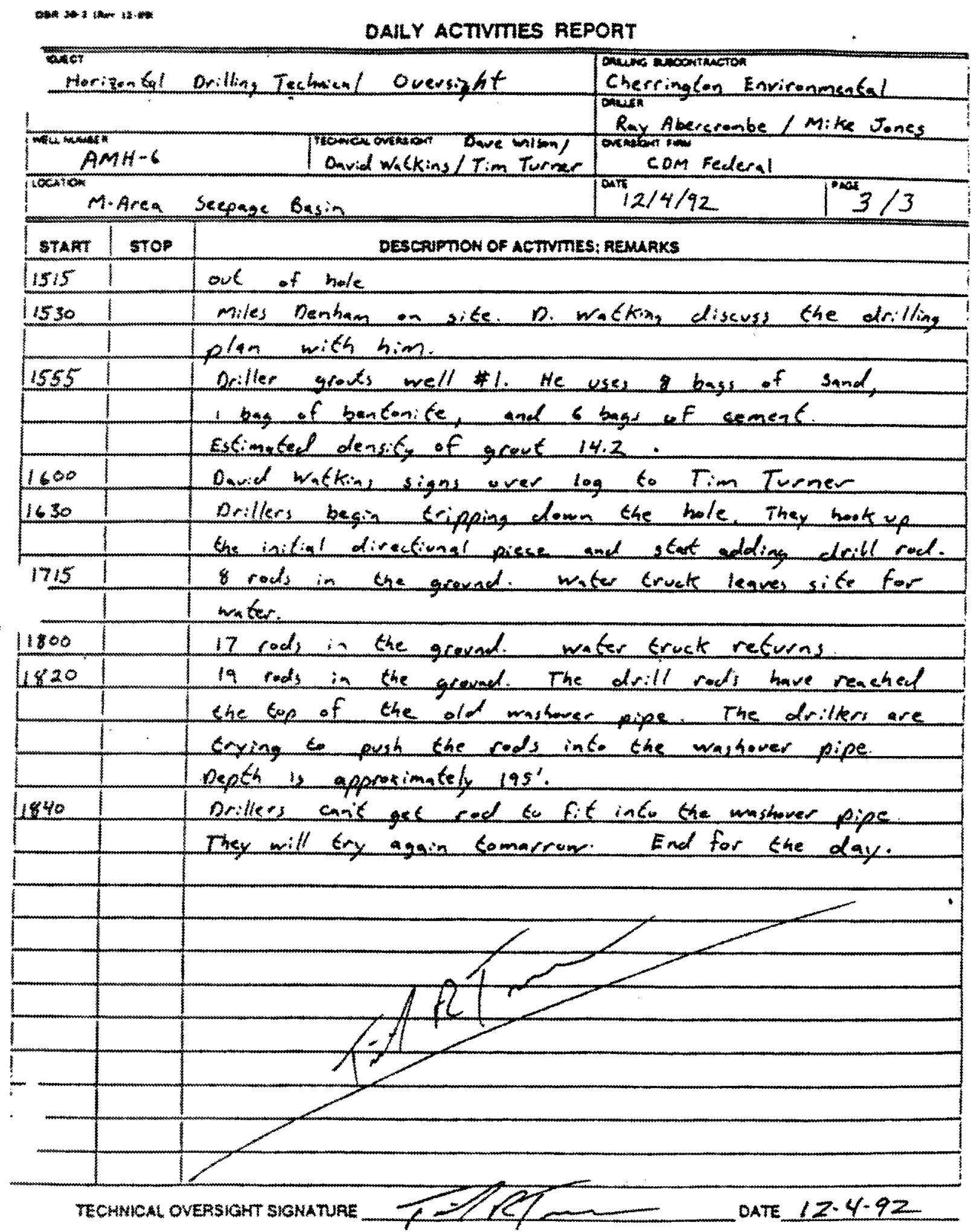


Denonastration of River Crossing Technology for Installation of Westinghouse Savannah River Company

Eavironmental Horizontal Wells: AMH-6 and AMH-7 Installation Report

CDM Federal Programs Corporation

Subcontract No. AA46325P

May \$, 1993

Task Order No. 10

10.t.

DALY ACTVTIES REPORT

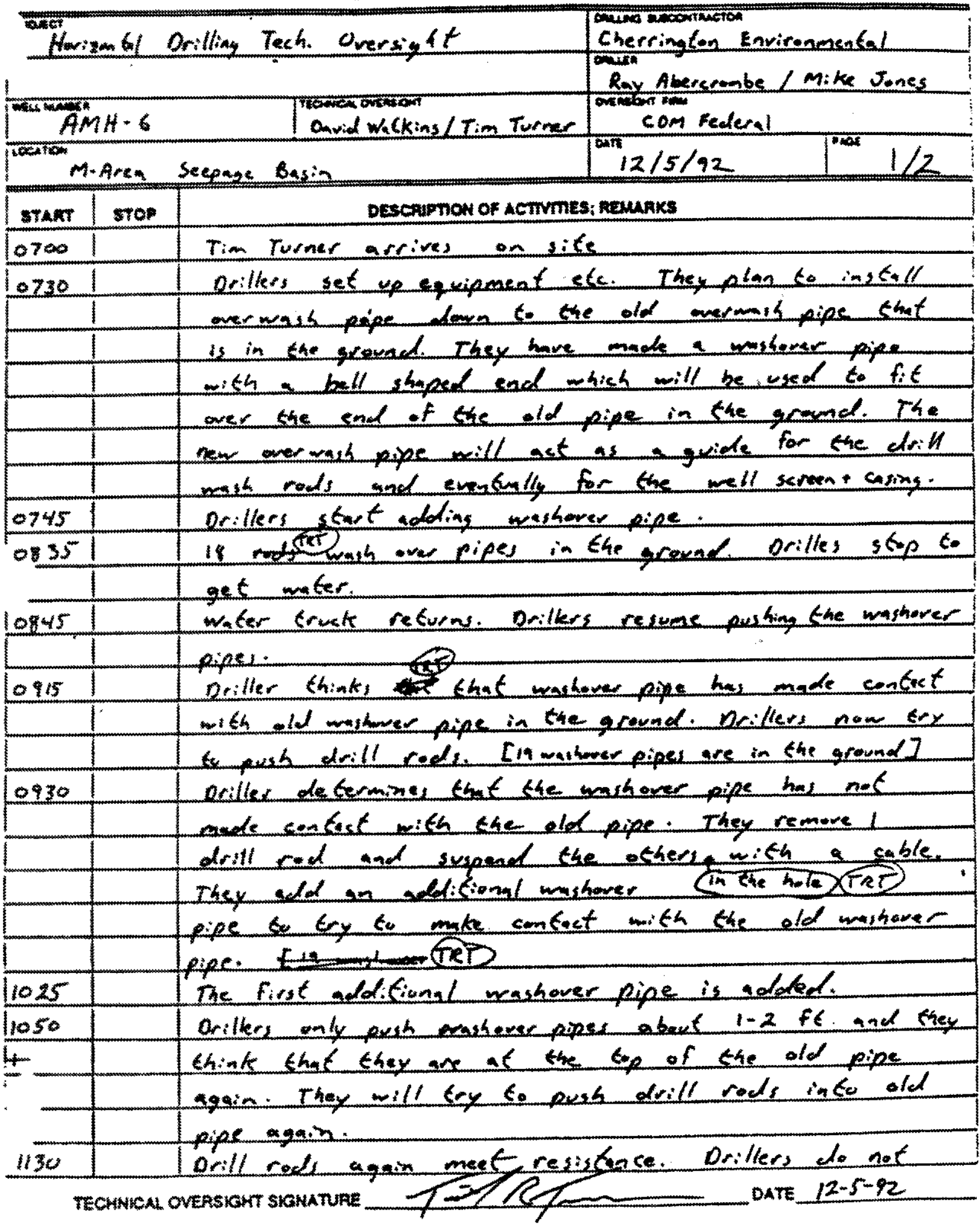

B-66 
Demonstration of River Crossing Technology for Installation of Environxwental Horizontal Wells: AMH-6 and AMH-7 Installation Report CDM Federal Programs Corporation

May 5. 1993
Westinghouse Savannah River Company

Subcontract No. AA46325P

Task Order No. 10

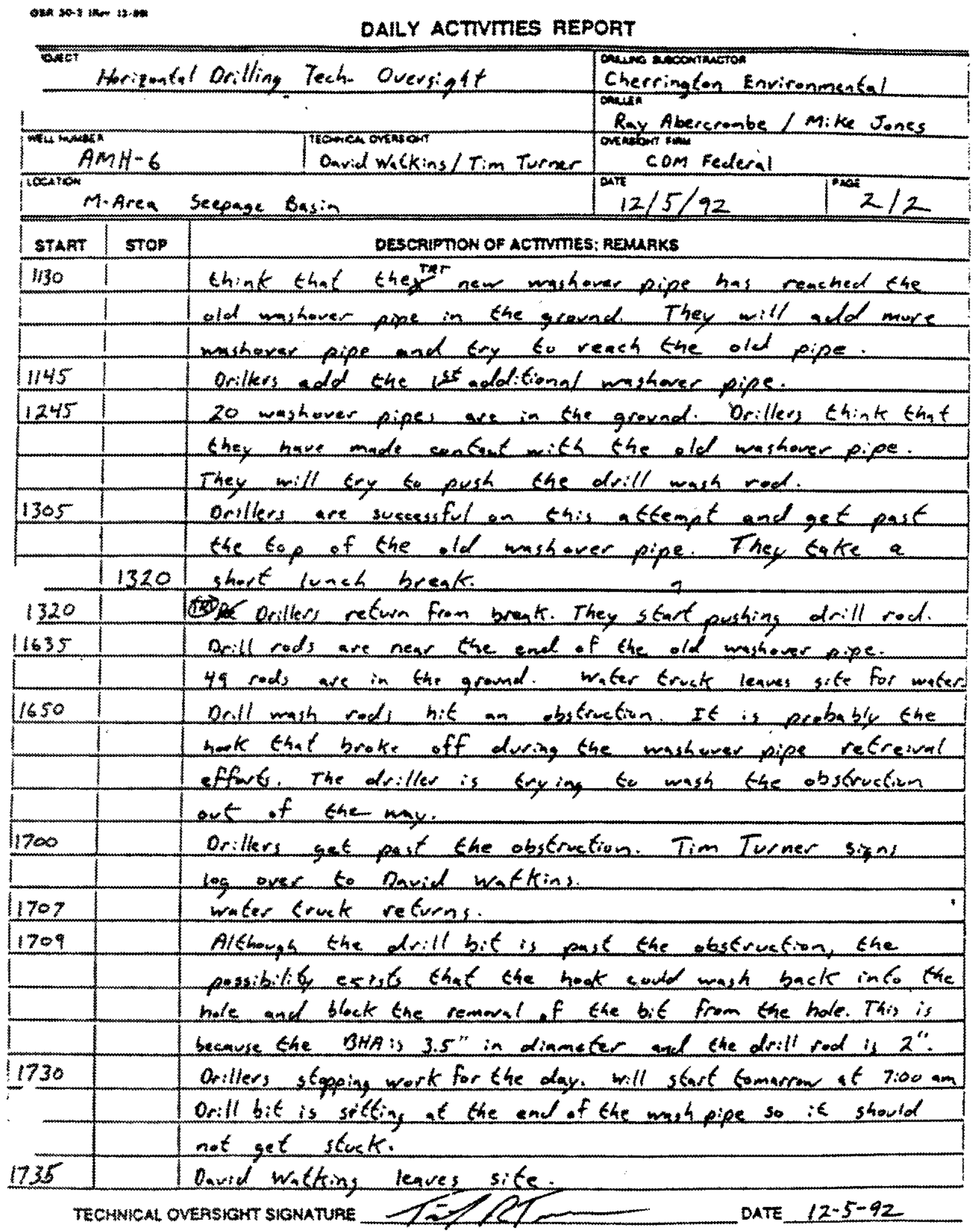


Dexnonstration of River Crossing Technology for Installation of COM Foderal Programs Comoration -6 and AMH-7 Installation Repor May 5, 1993
Westinghouse Savannah River Company Subcontract No. AA46325P Task Onder No. 10

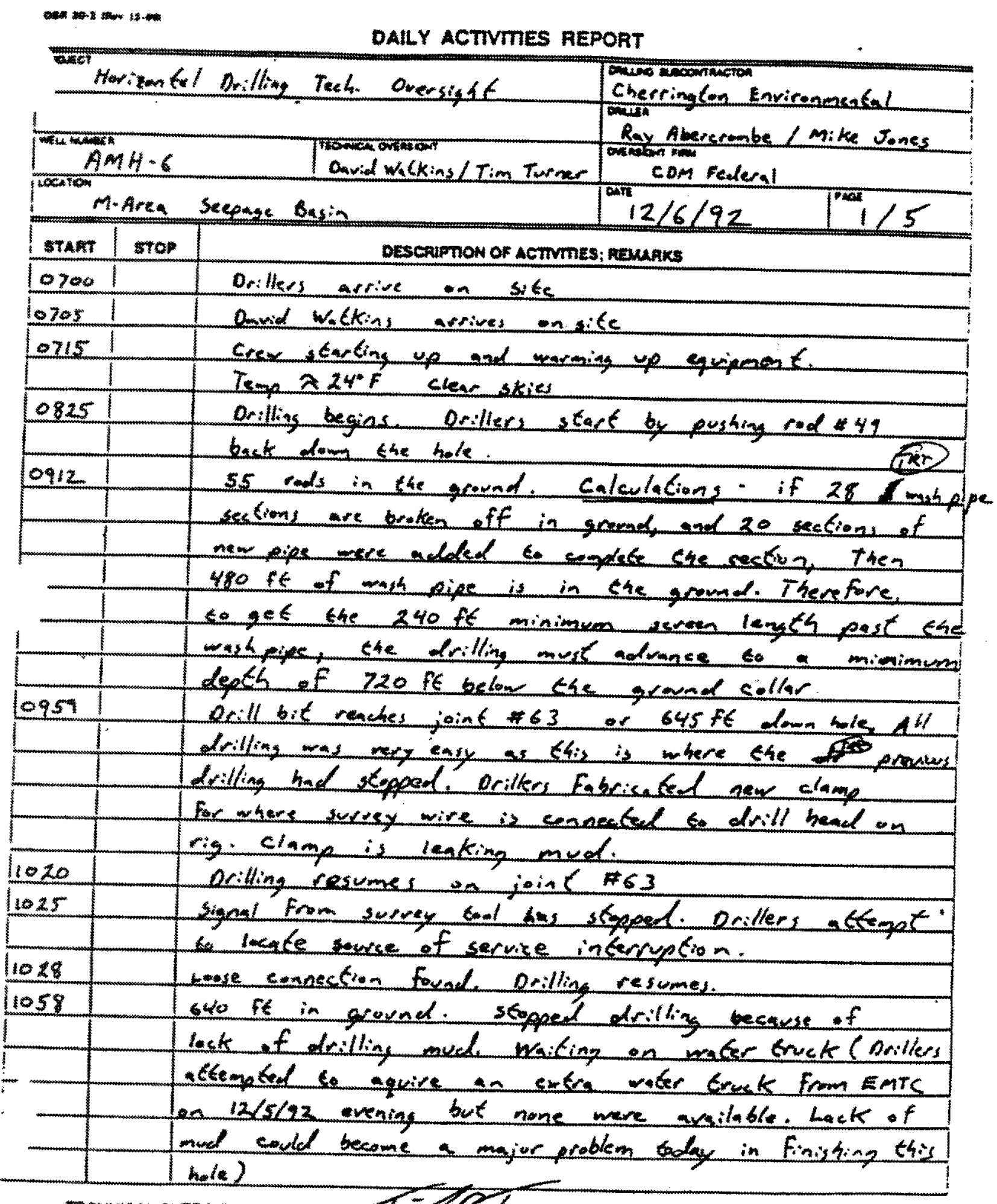

TECHNLAL OVERSIGH SIGNATUAE DATE $12-6-92$ 
Demonstration of River Crossing Technology for lastallation of Environtwental Horizontal Wells: AMH-6 and AMH-7 Installation Repon CDM Federal Programas Corporation May 5,1993
Westinghouse Savannah River Company Subcontract No. AA46325P Task Order No. 10

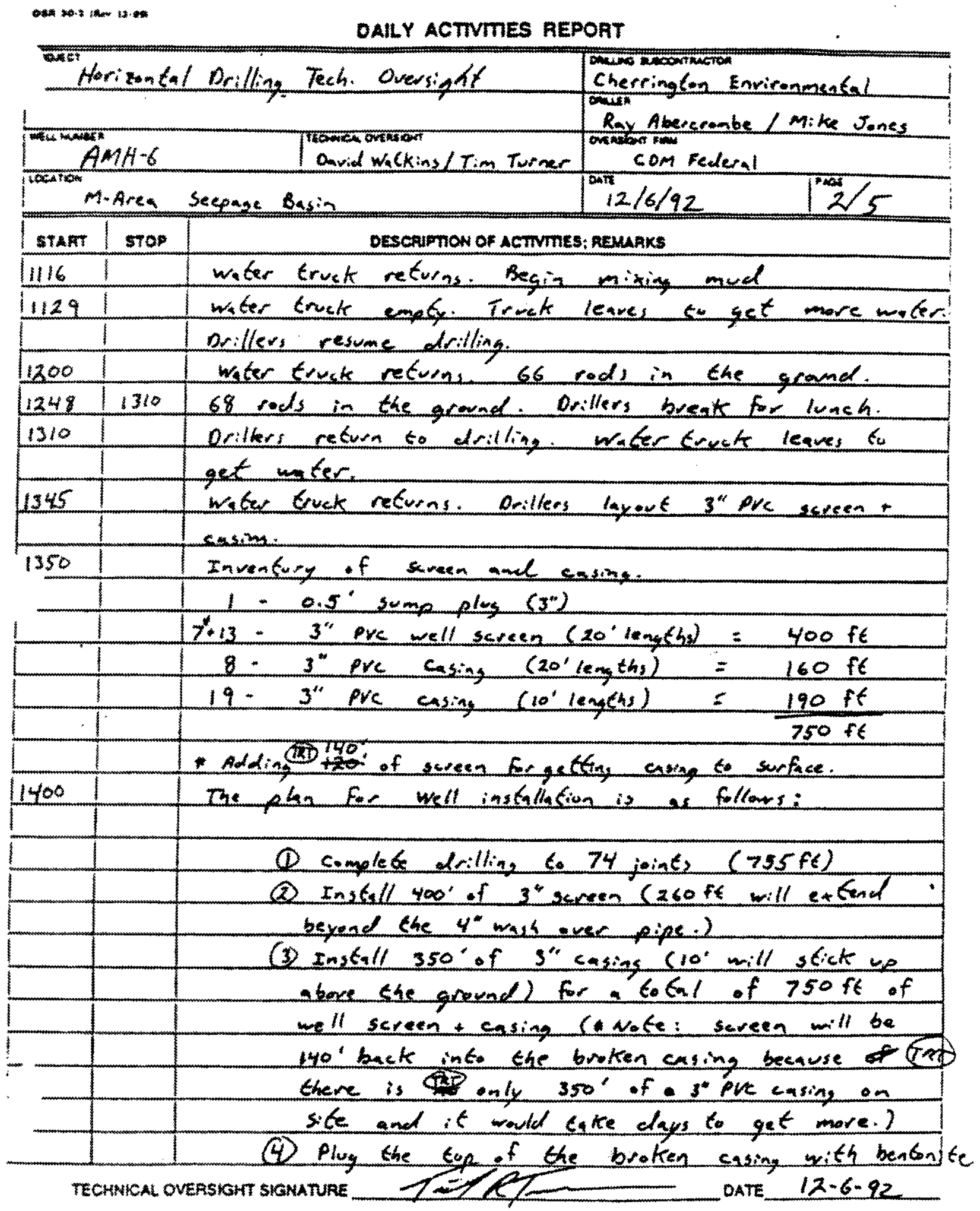


Demonstration of River Crossing Technology for Installation of

Eavironmental Horizontal Wells: AMH-6 and AMH-7 Installation Report

CDM Federal Programs Corporation

Westinghouse Savannah River Company

May 5.1993

Subcontract No. AA46325P

*a*

Task Order No. 10

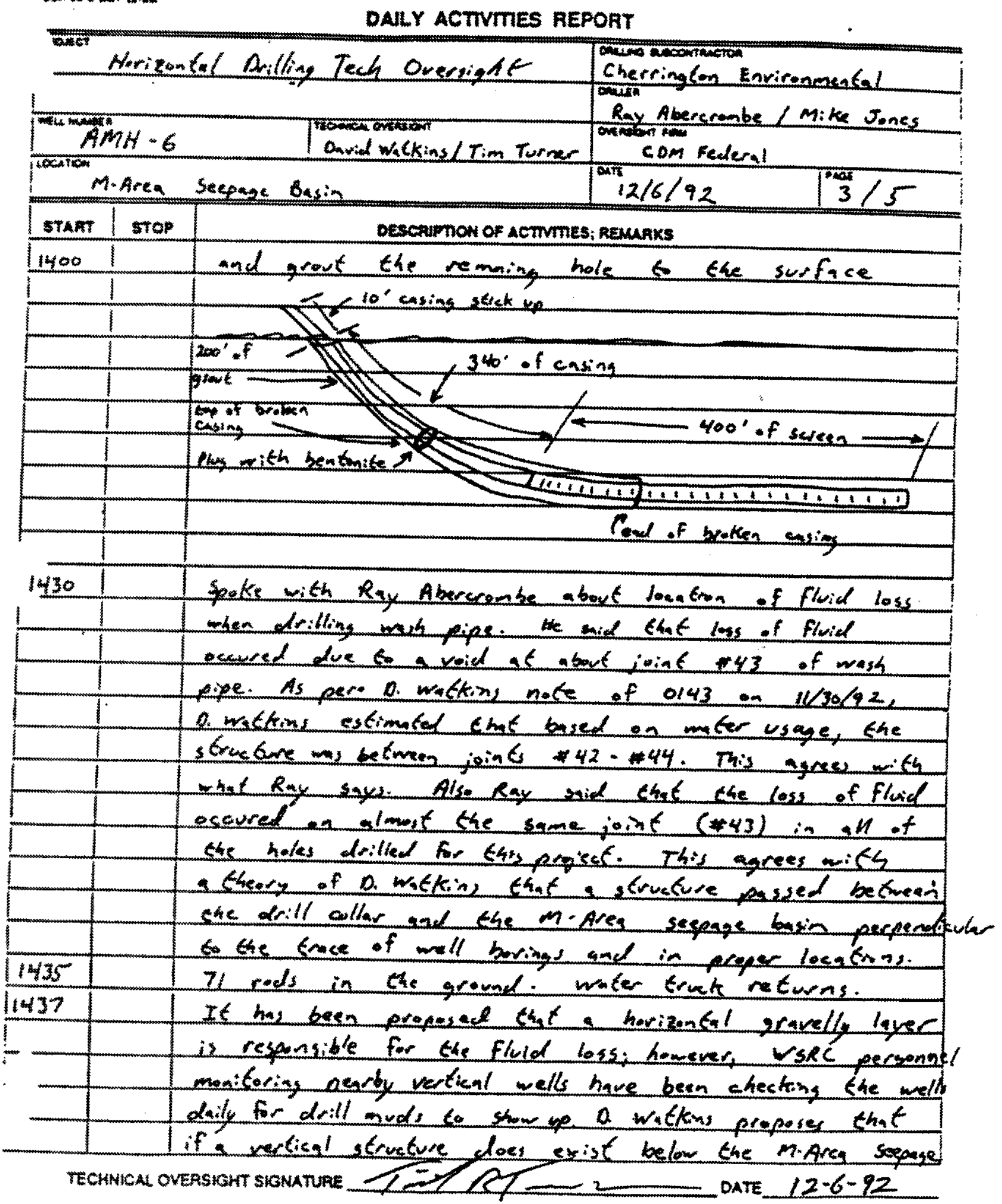

B-70 
Demonstration of River Crossing Technology for Installation of Environmental Horizontal Wells: AMH-6 and AMH 7 Installation Report CDM Federal Programs Corporation May 5,1993
Westinghouse Savannah River Company Subcontract No. AA46325P

Task Order No. 10

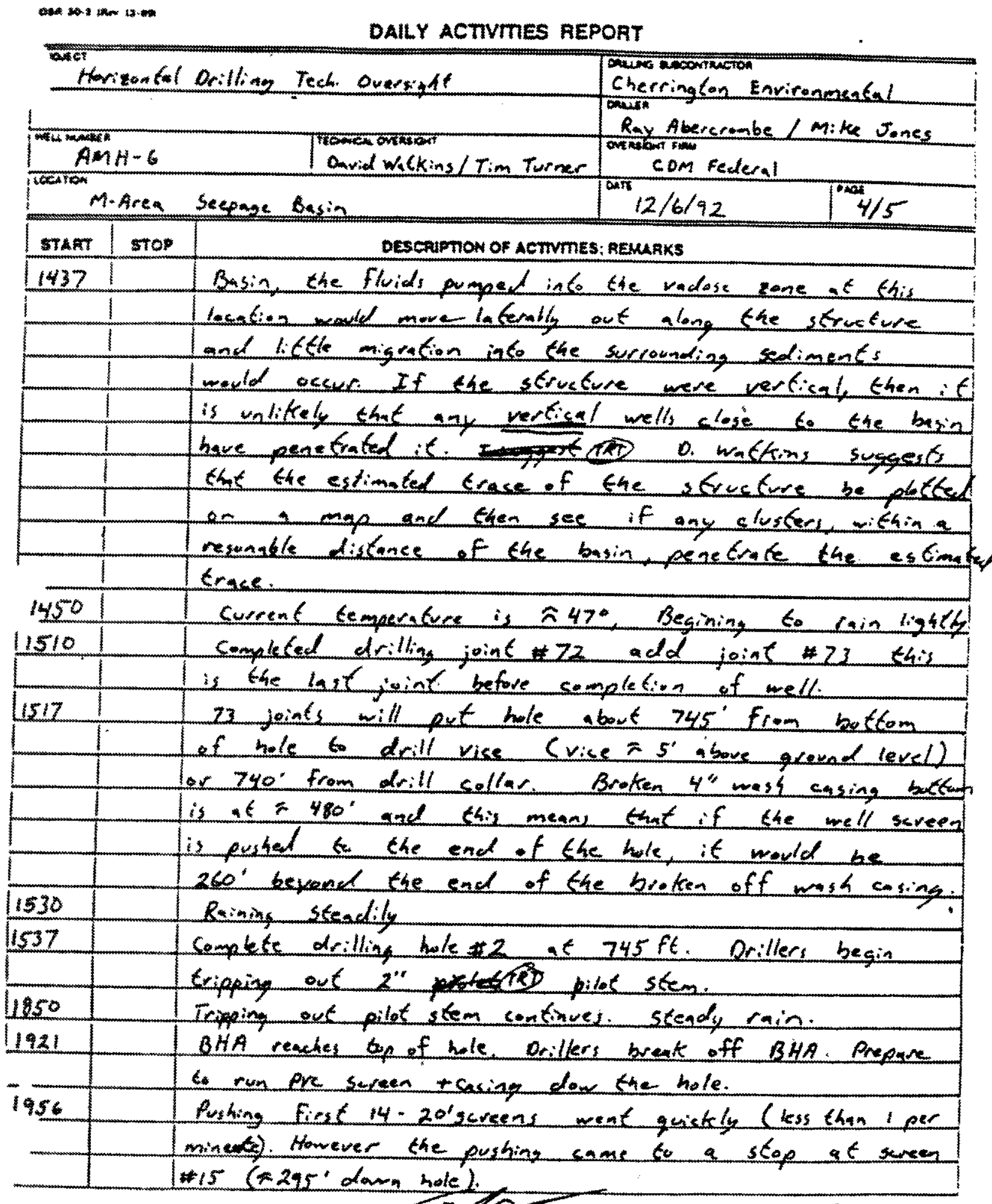

TECHNHCAL OVERSIGHT SIGNATURE hole) DATE $12-6-9 z$ 
Demonstration of River Crossing Technology for Installation of Westinghouse Savannah River Company Eavironmental Horizontal Wells: AMH-6 and AMH-7 Installation Report Subcontract No. AA46325P CDM Federal Programs Corporation

Task Order No. 10

May 5. 1993

\section{DALYY ACTIVITES REPORT}

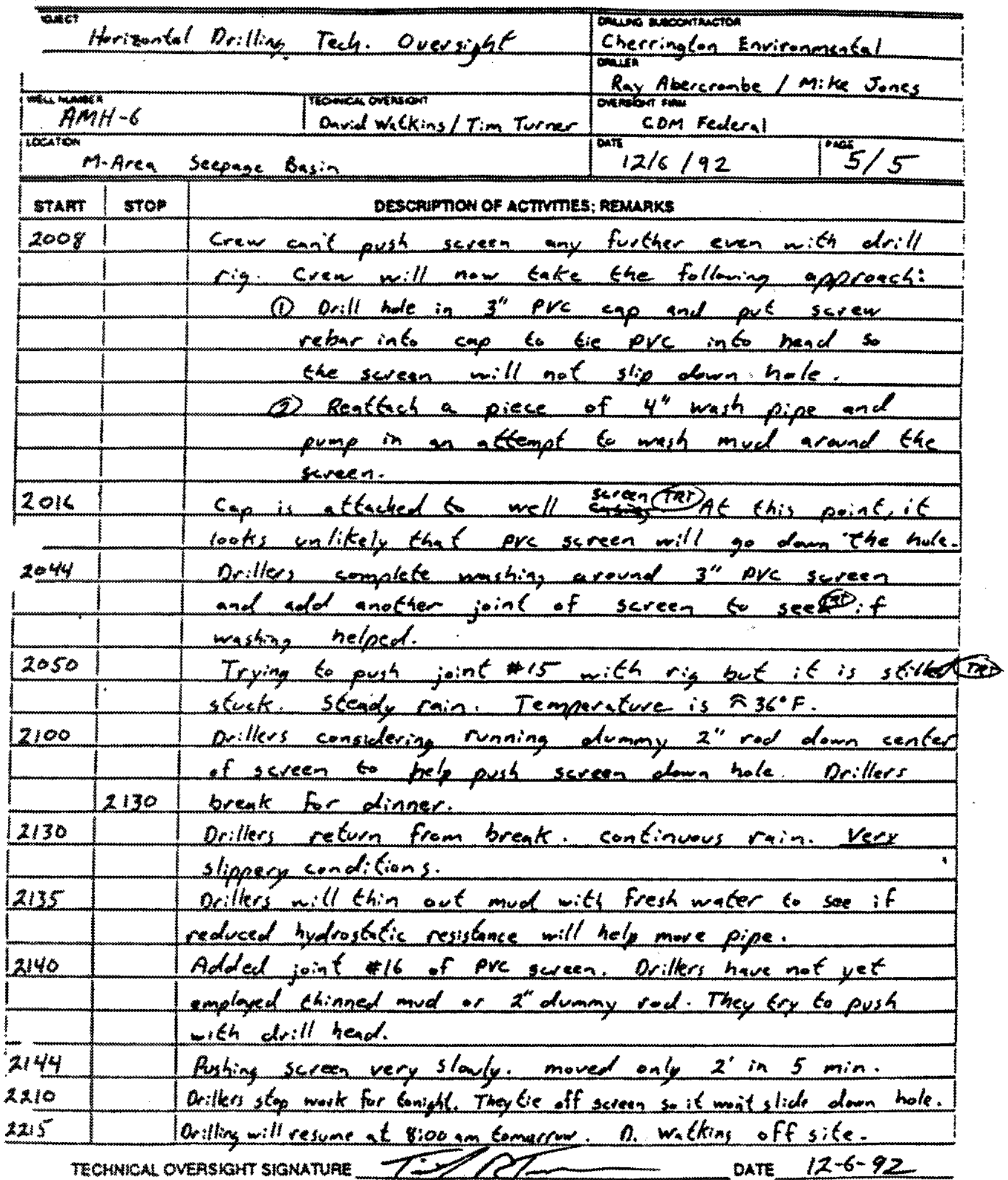


Demonstration of River Crossing Technology for Installation of Westinghouse Savannah River Company

Environmental Horizontal Wells: AMH-6 and AMH-7 Installation Report

CDM Federal Programs Corporation

Subcontract No. AA46325P

May $\$, 1993$

Task Order No. 10

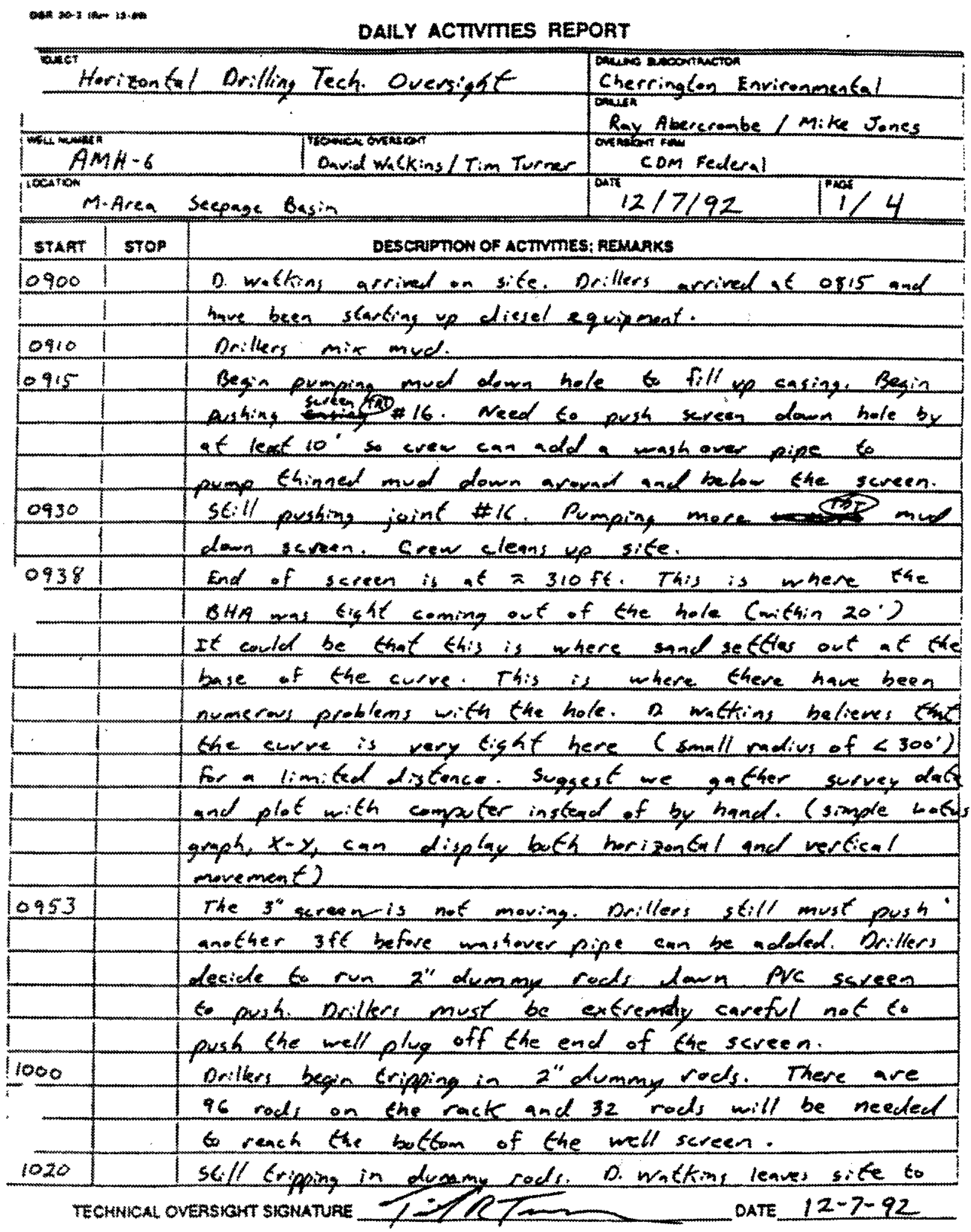


Demonstration of River Crossing Technology for Installation of Westinghouse Savannah River Company Environamental Horizontal Wells: AMH-6 and AMH-7 Installation Report CDM Federal Programs Corporation

Subcontract No. AA4632sP

May 5,1993

Task Order No. 10

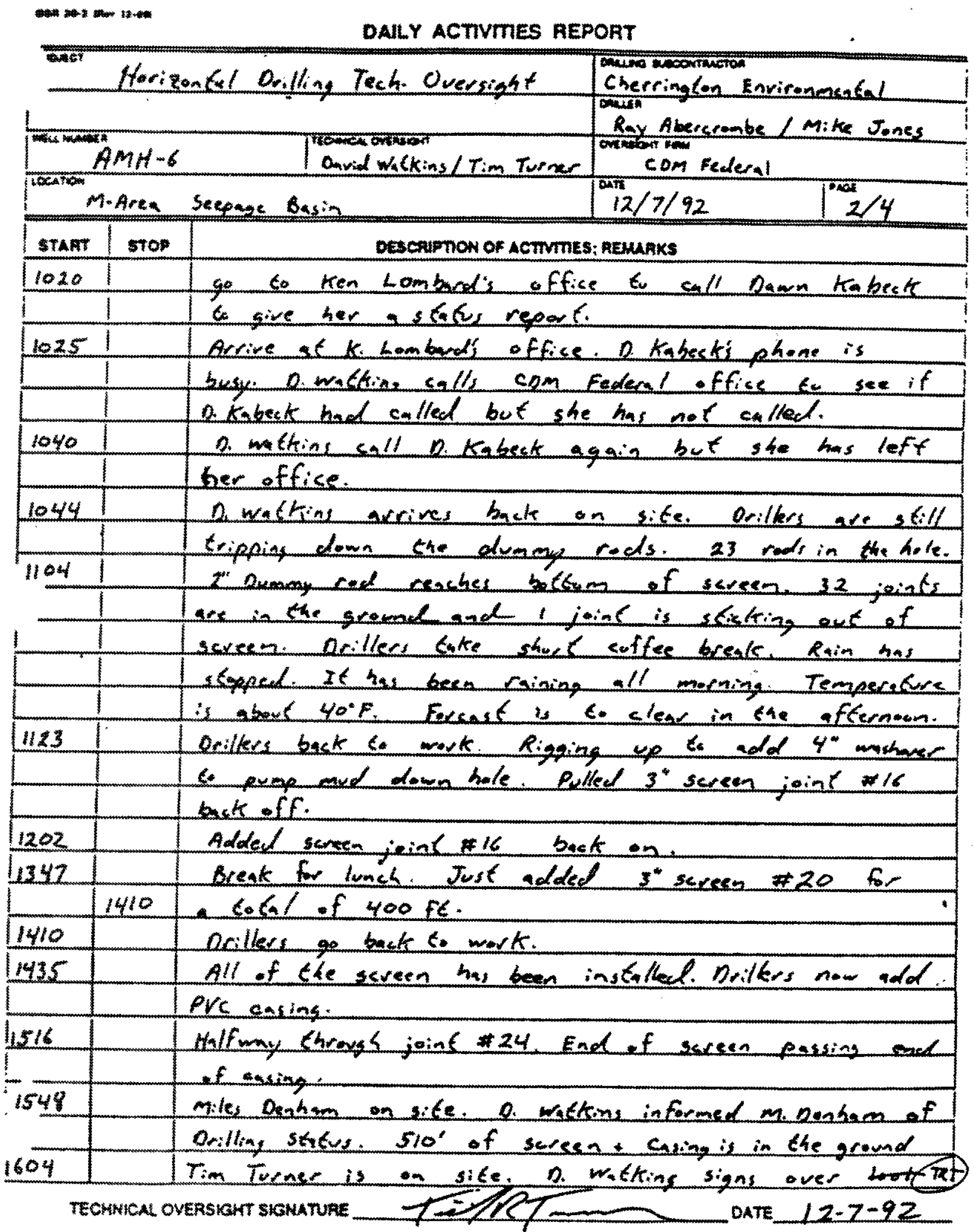


Dexnonstration of River Crossing Technology for Installation of Environmental Horizontal Wells: AMH-6 and AMH-7 Installation Report CDM Federal Programs Corporation

May 5,1993
Westinghouse Savannah River Company Subcontract No. AA46325P

Task Order No. 10

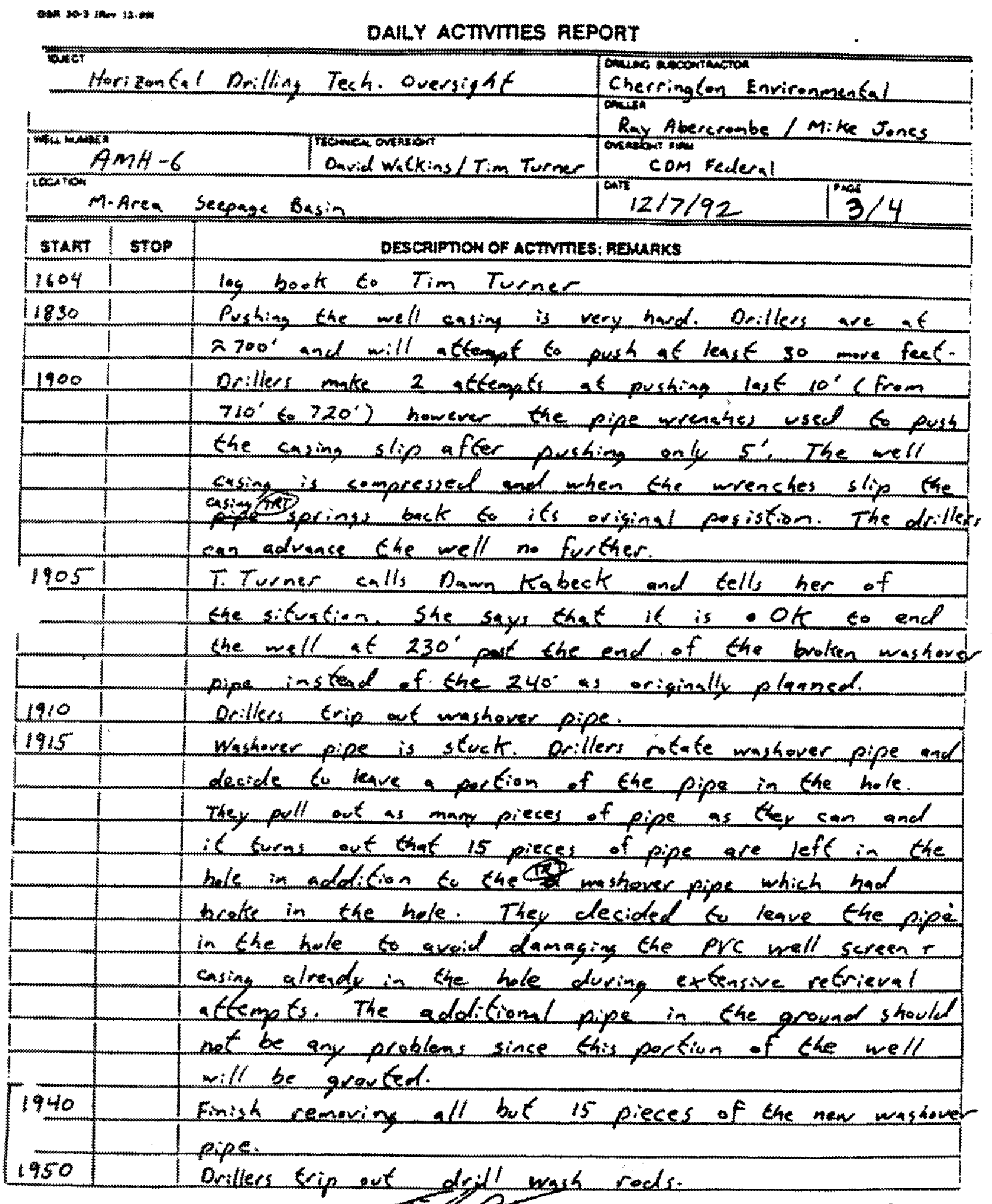

TECHNICAL OVERSKGH SIGNATURE DATE $12-7-92$ 
Demonstration of River Crossing Tectnology for Installation of Westinghouse Savannah River Company Environmenta Horizontal Wells: AMH-6 and AMH-7 Installation Report CDM Federal Programs Corporation

Subcontract No. AA46325P May 5, 1993

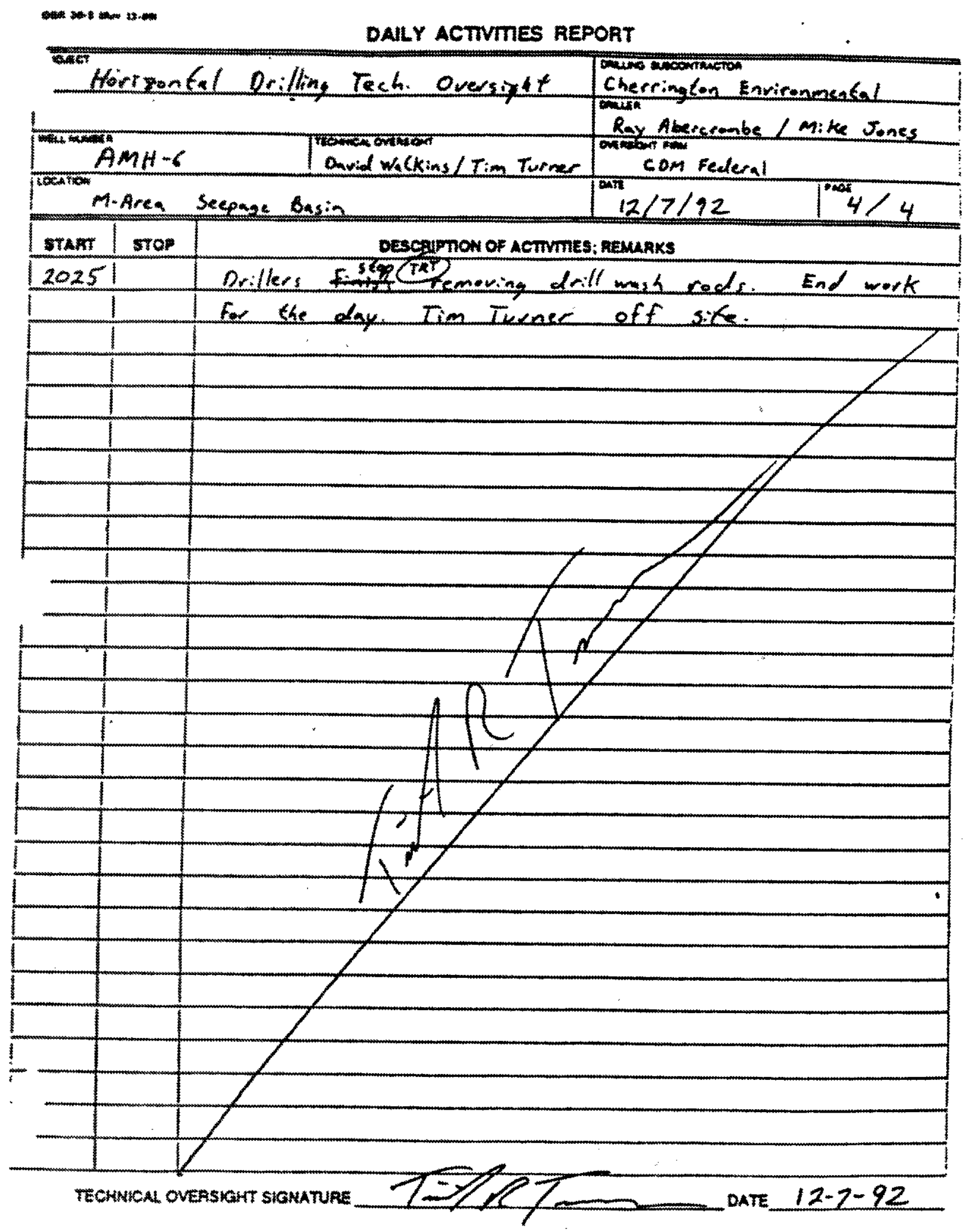


Demonstration of River Crossing Technology for Installation of Environmental Horizontal Wells: AMH-6 and AMH-7 Installation Report CDM Federal Programs Corporation

May 5, 1993
Westinghouse Savannah River Company

Subcontract No. AA46325P

Task Order No. 10

201000

DAILY ACTIVITES REPORT

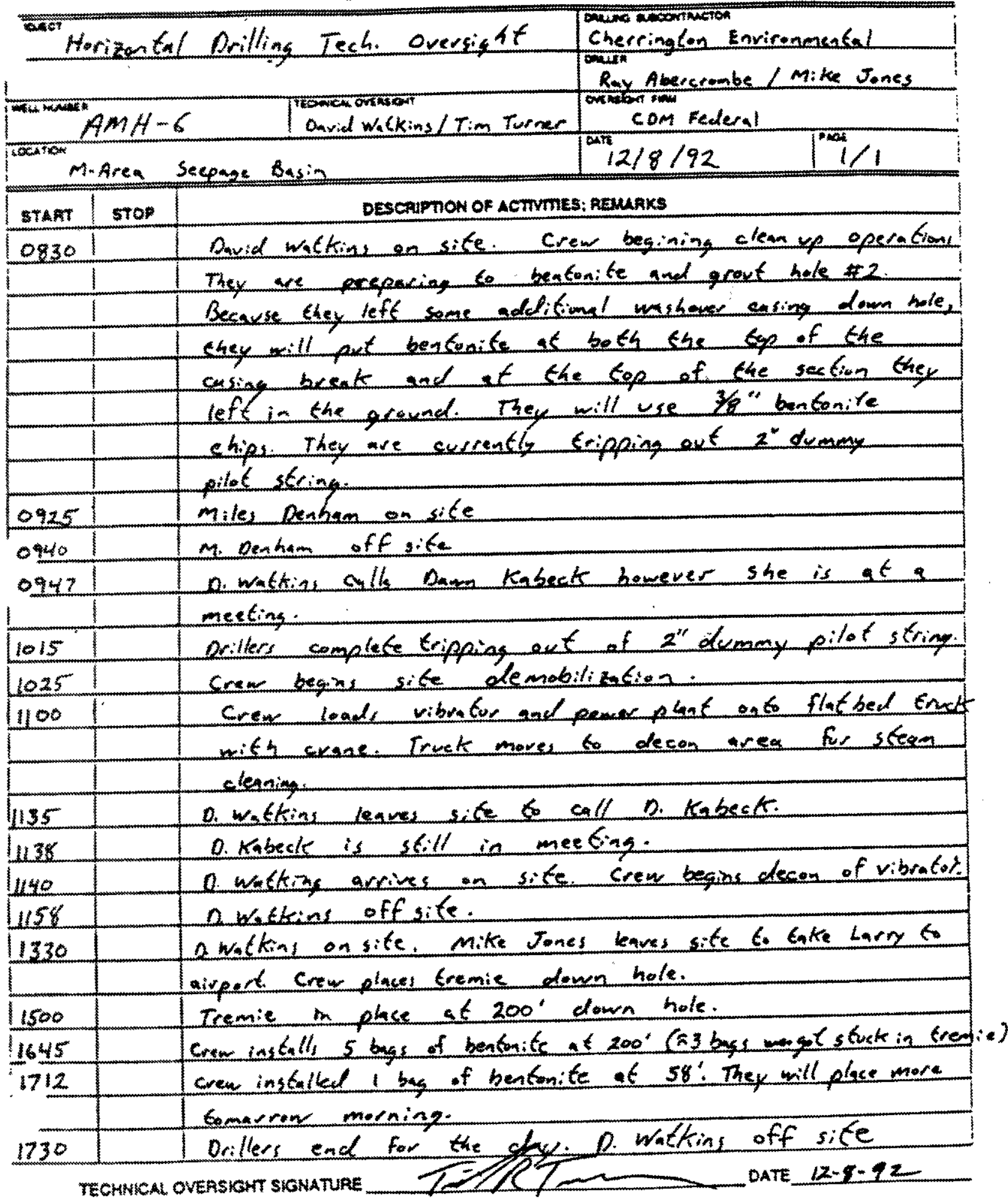


Demonstration of River Crossing Technology for Installation of Enviromental Horizontal Wells: AMH-6 and AMH-7 Installation Report May 5, 1993
Westinghouse Savannah River Company Subcontract No. AA46325P

Task Order No. 10

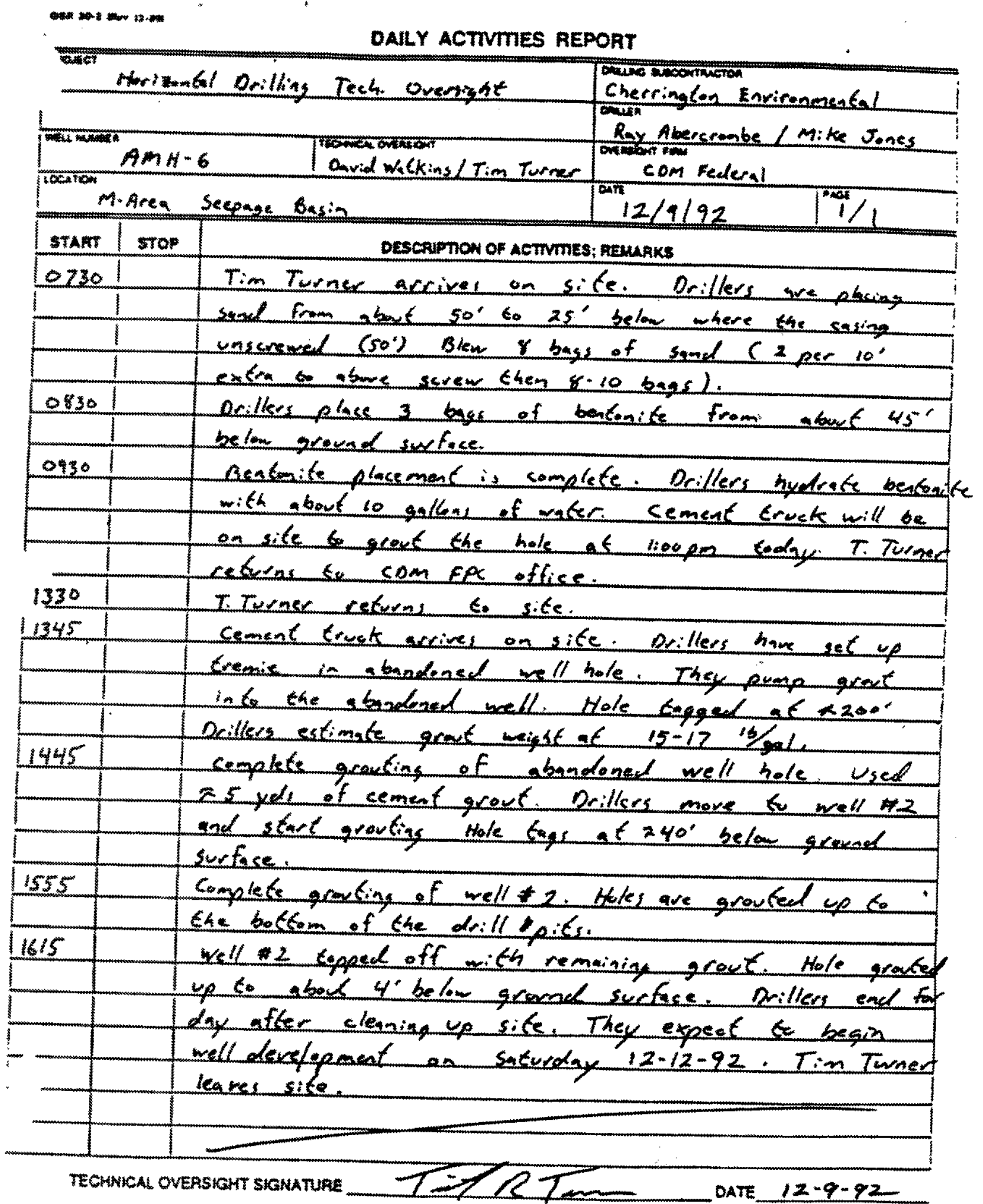


Demonstration of River Crossing Technology for Installation of Environmental Horizontal Wells: AMH-6 and AMH-7 Installation Report CDM Federal Programs Corporation May 5,1993
Westinghouse Savannah River Company Subcontract No. AA46325P Task Order No. 10

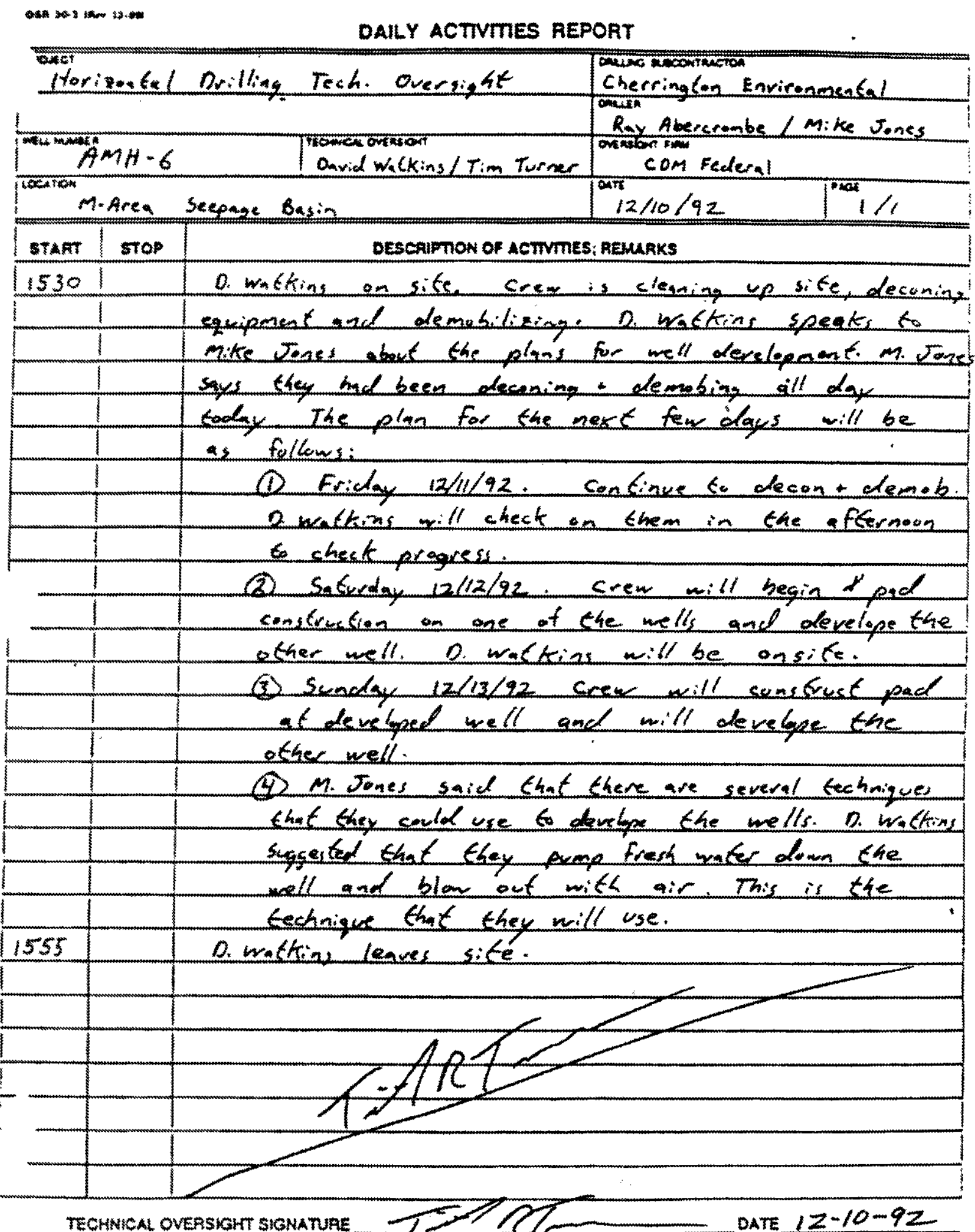


Demonstration of River Crossing Technology for Installation of Eavironmental Horizontal Wells: AMH-6 and AMH-7 Installation Report COM Federal Programs Corporation

May 5, 1993
Westinghouse Savannah River Company Subcontract No. AA46325P Task Order No. 10

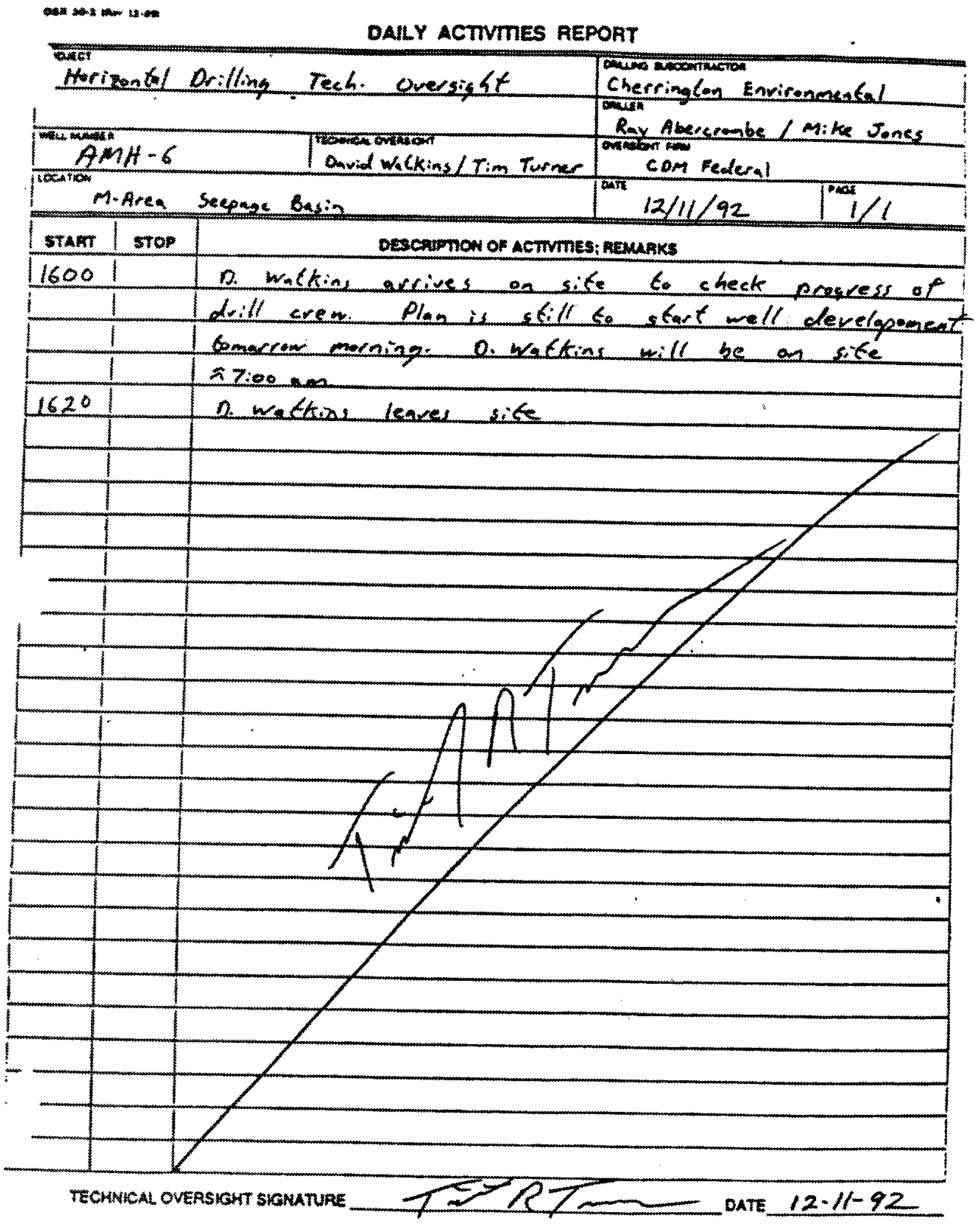


Demonstration of River Crossing Technology for Installation of Westinghouse Savannah River Company Environmental Horizontal Wells: AMH-6 and AMH-7 Installation Report CDM Federal Programs Comporation

Subcontract No. AA46325P

May 5,1993

Task Order No. 10

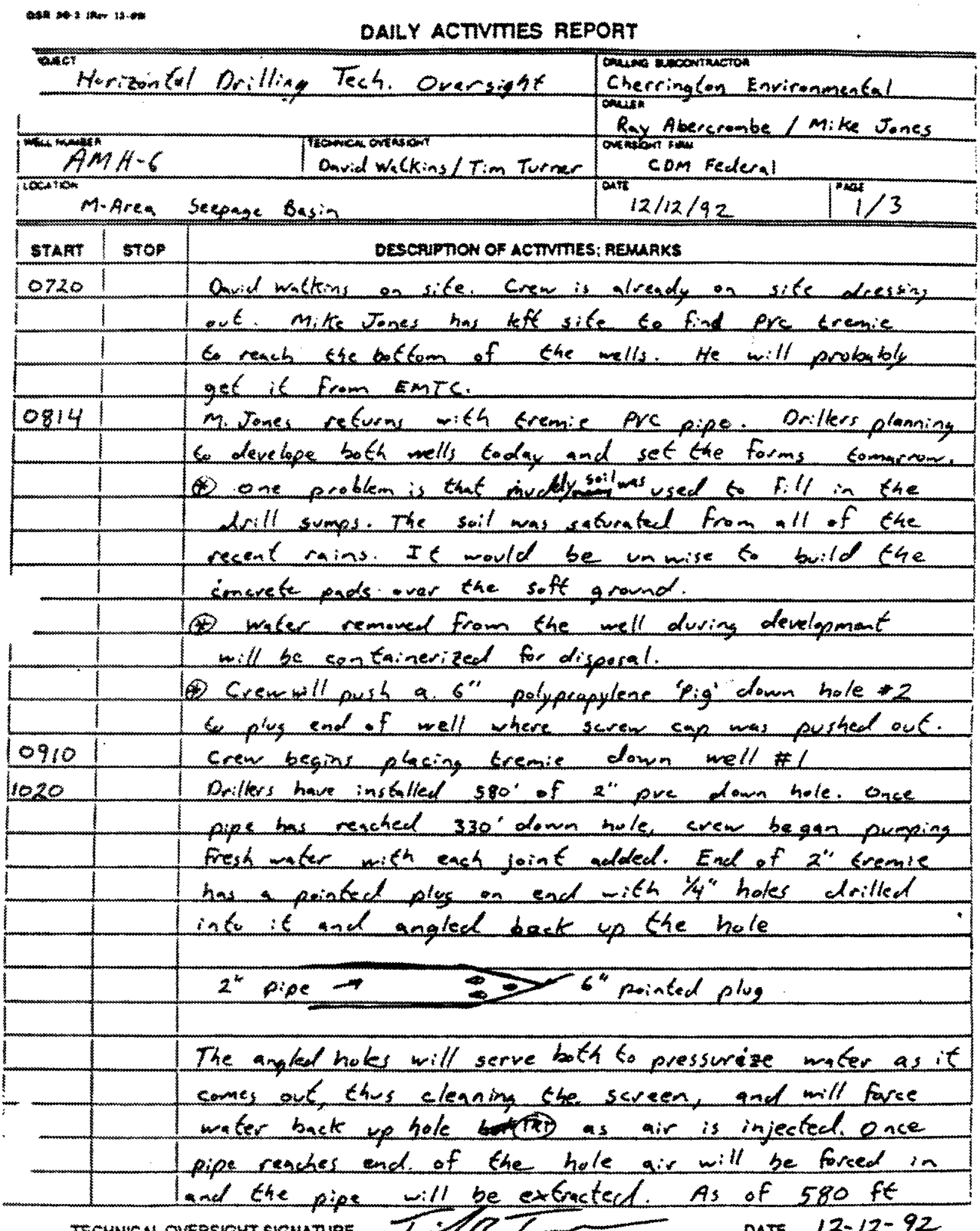


Denonstration of River Crossing Technology for Installation of Environmental Horizontal Wefls: AMH-6 and AMH-7 Installation Repon CDM Federal Programs Corporation

May 5,1993
Westinghouse Savannah River Company

Subcontract No. AA46325P

Task Order No. 10

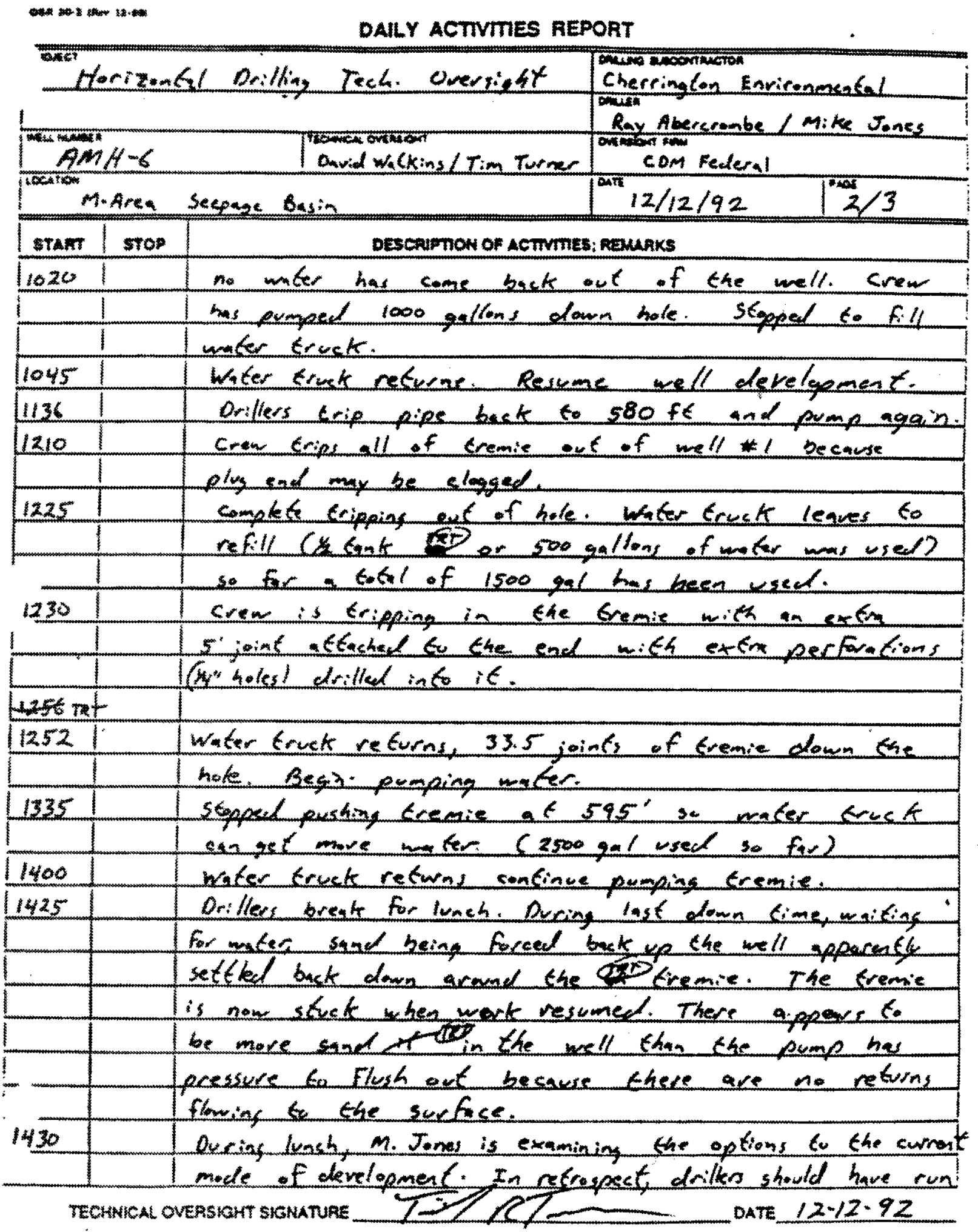


Demonstration of River Crossing Technology for Installation of Environmental Horizontal Wells: AMH-6 and AMH-7 Installation Report CDM Federal Programs Corporation May 5,1993
Westinghouse Savannah River Company Subcontract No. AA46325P Task Order No. 10

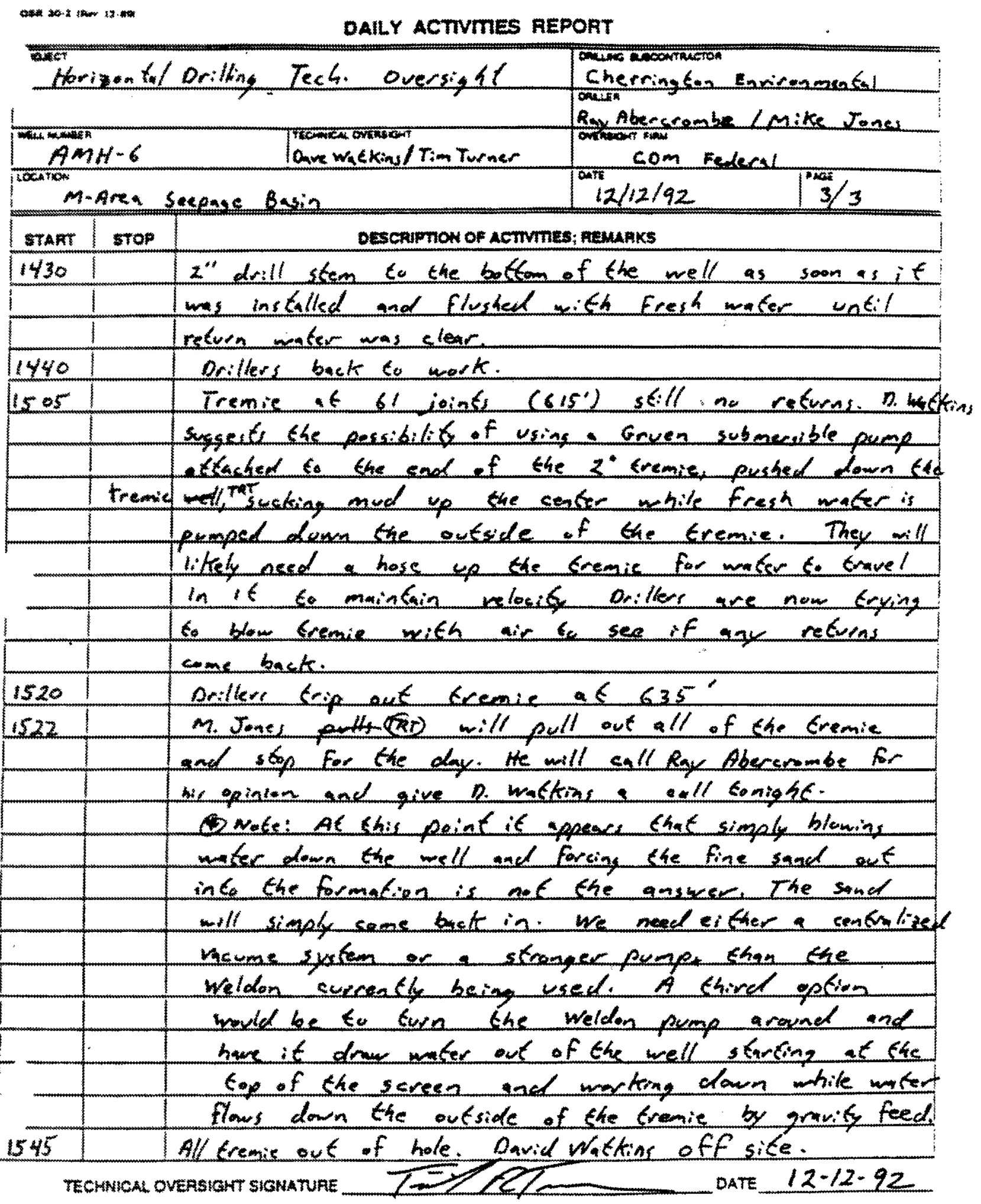


Demonstration of River Crossing Technology for Installation of Envirommental Horizontal Wells: AMH-6 and AMH-7 lastallation Report CDM Federal Programs Corporation

May 5, 1993
Westinghouse Savannah River Company Subcontract No. AA46325P Task Order No. 10

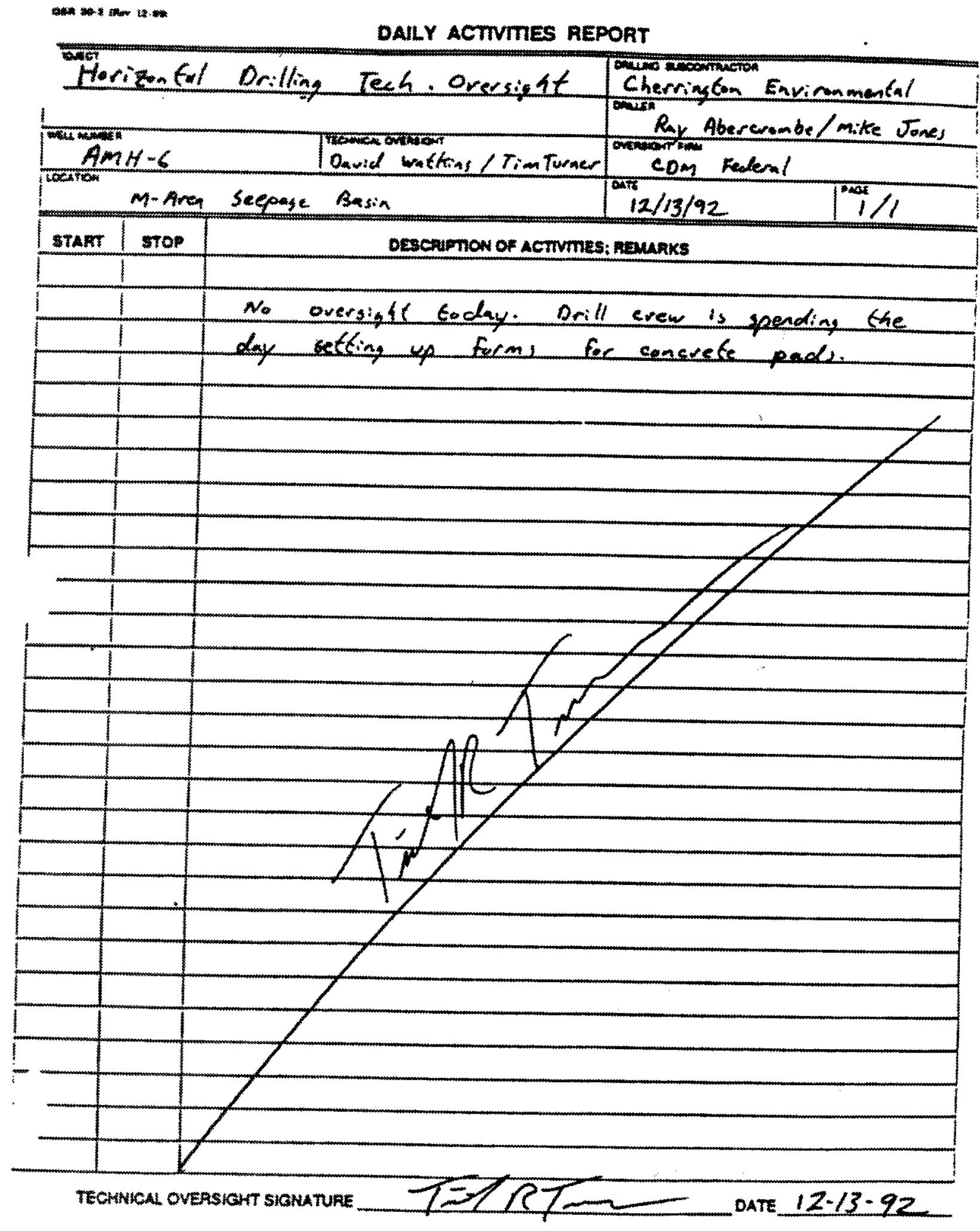


Demonstration of River Crossing Technology for Installation of Eavironmental Horizontal Wells AMH-6 and AMH-7 Installation Report CDM Federal Programs Corporation

May 5,1993
Westinghouse Savannah River Company Subcontract No. AA46325P Task Order No. 10

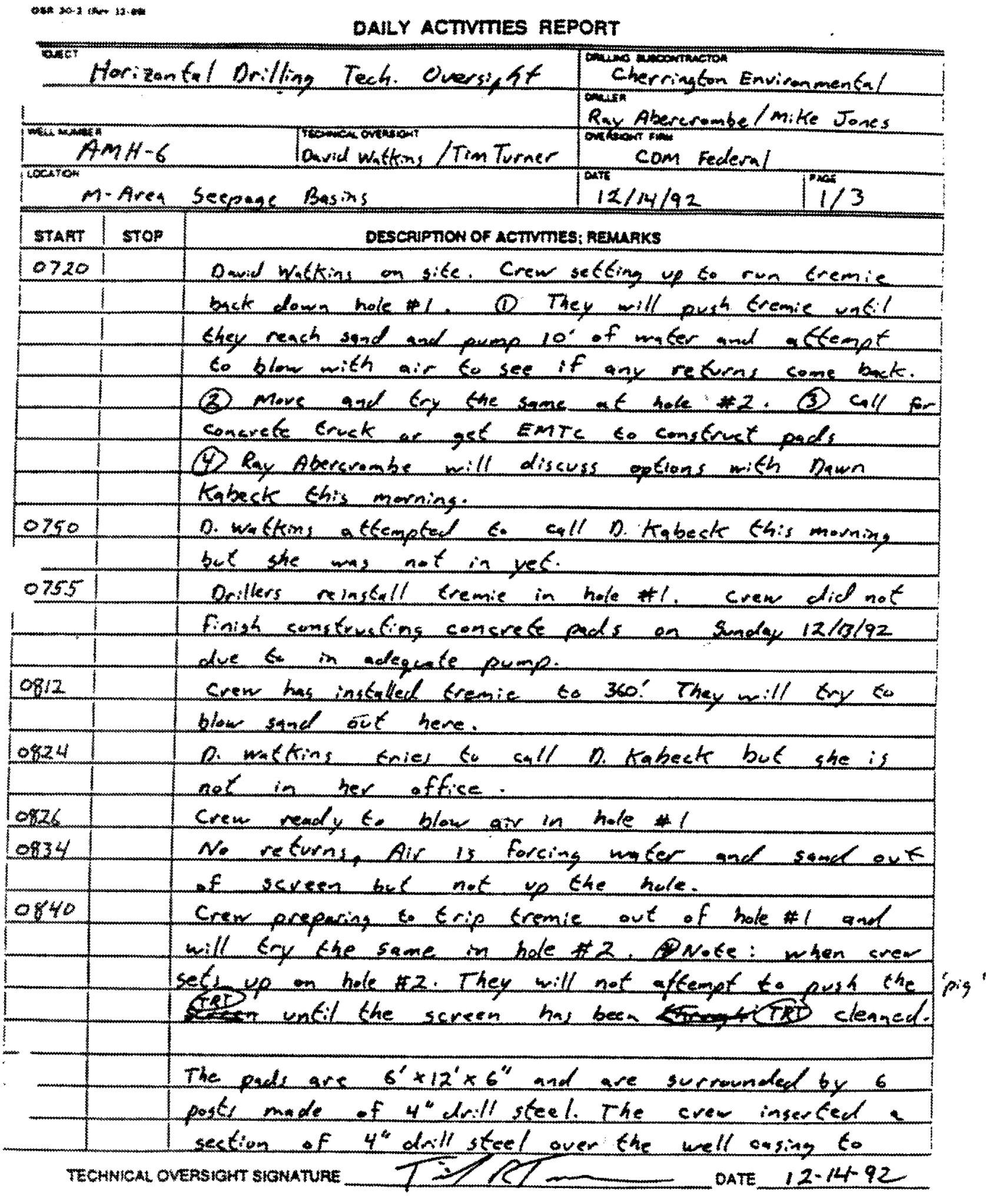


Demacastration of River Crossing Tectnology for Installation of Eavironmental Horizontal Wells: AMH -6 and AMH-7 Installation Report CDM Federal Programs Corporation

May 5,1993
Westinghouse Savannah River Company

Subcontract No. AA46325P

Task Order No. 10

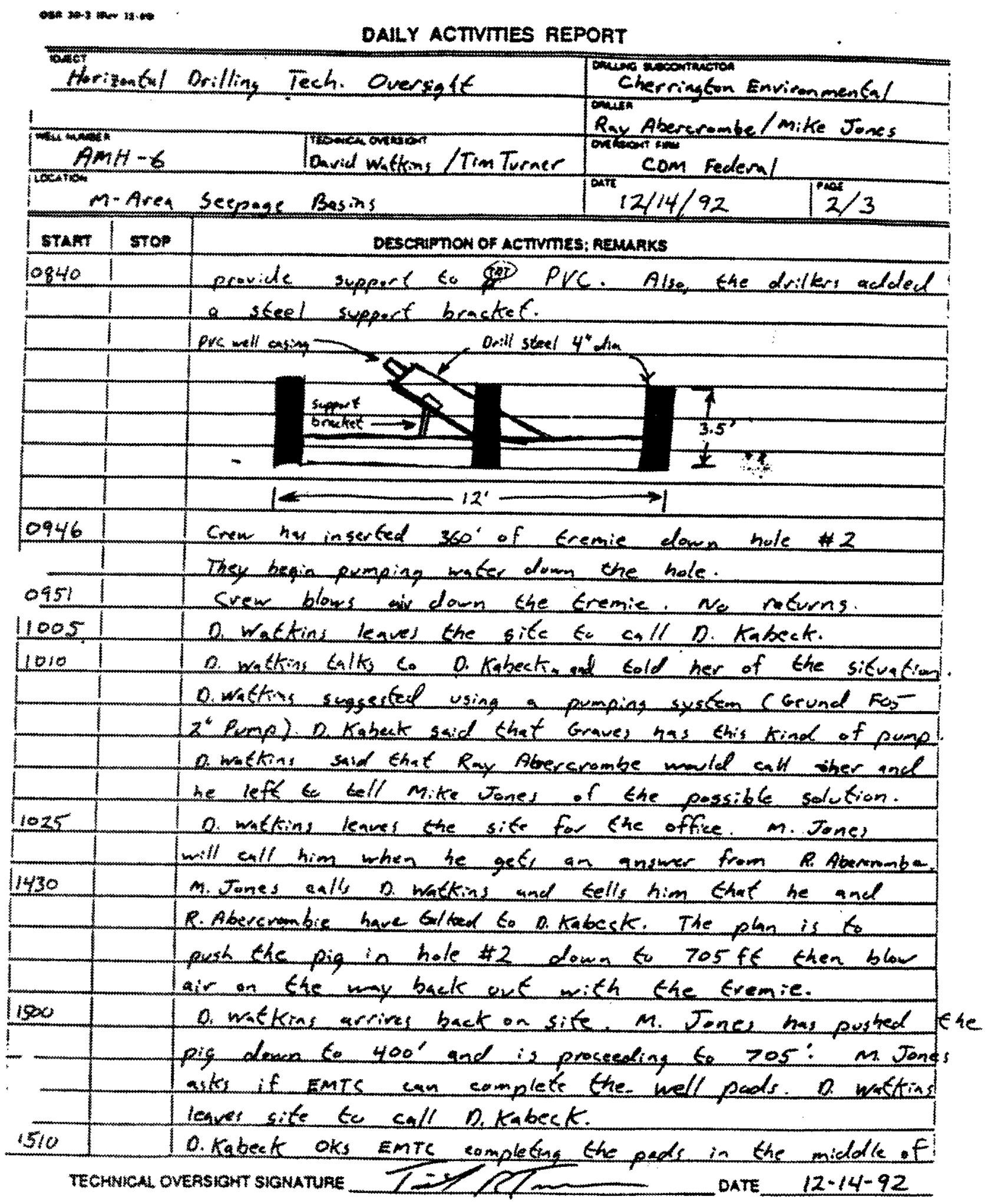


Dexoonstration of River Crossing Technology for Installation of Westinghouse Savannah River Company Environmental Honizontal Wells: AMH -6 and AMH-7 Installation Report CDM Federal Programs Corporation

Subcontract No. AA46325P

May $\$ .1993$

Task Order No. 10

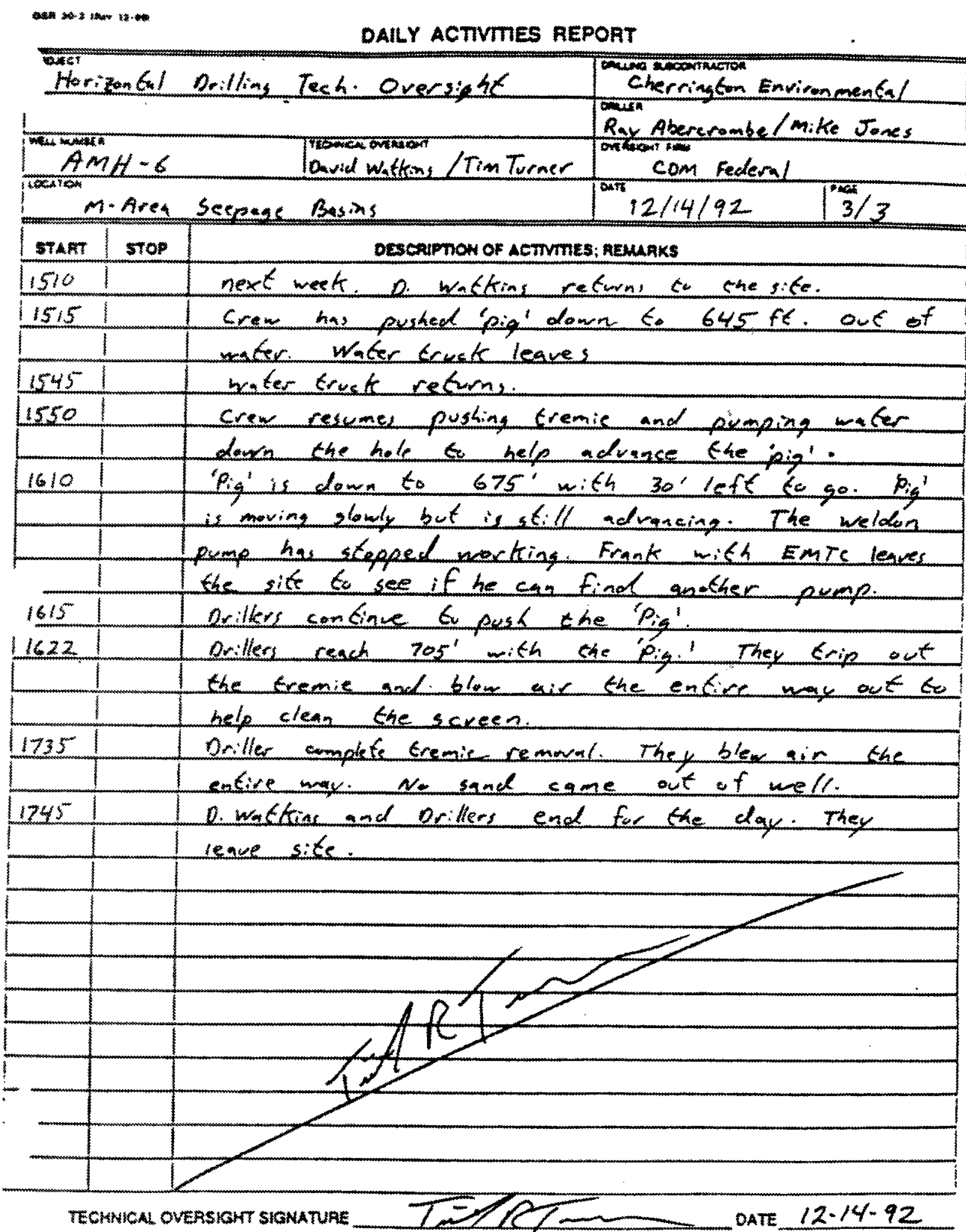


Demonstration of River Crossing Technology for Installation of Westinghouse Savamah River Company Envirctamental Horizontal Wells: AMH-6 and AMH-7 Installation Report CDM Federal Programs Corporation Subcontract No. AA46325P May 5, 1993

Task Order No. 10

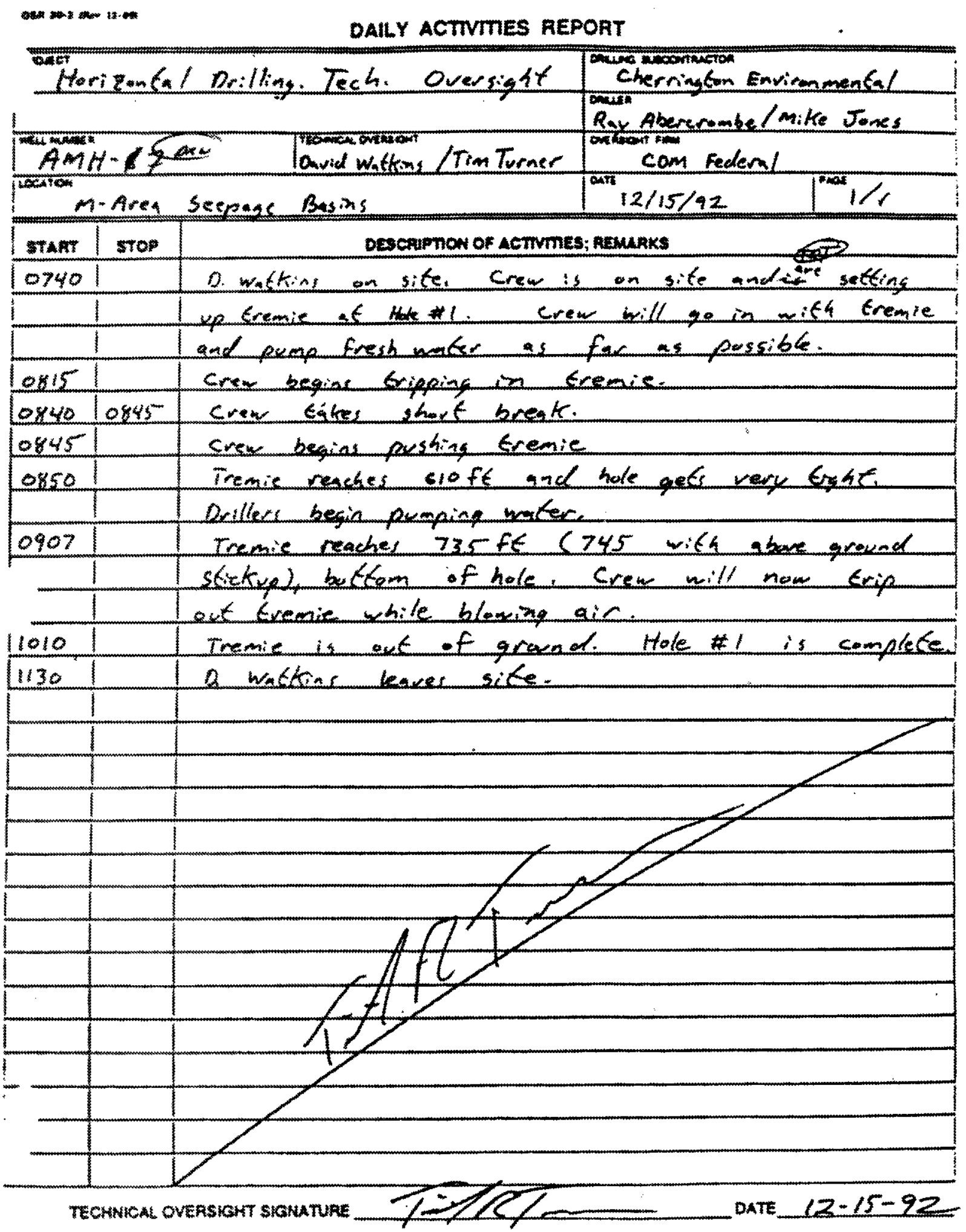


Demonstration of River Crossing Technology for Installation of Euvironmental Horizomtal Wells: AMH -6 and AMH-7 Installation Report CDM rederal Programs Corporation

May 5.1993
Westinghouse Sayannah River Company

Subcontract No. AA46325P

Task Order No. 10

\section{APPENDIX C}

M AREA HORIZONTAL DRILLING PHÓTOGRAPHS 
Demonstration of River Crossing Technology for Installation of

Westinghouse Savannah River Company Environmentul Horixontal Wells: AMH 6 and AMH 7 lnstallation Report CDM Foderal Programs Comporation Subcontract No. AA46325P May 5,1993

Task Order No. 10

\section{THIS PAGE INTENTIONALLY LEFT BLANK}


Damonstration of River Crossing Tochnology for Installation of

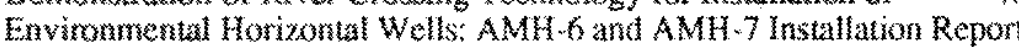
CDM Fodera Programs Comoration

May 5,1993
Westinghouse Savannah River Company Subcontract No. AA46325P Task Order No. 10

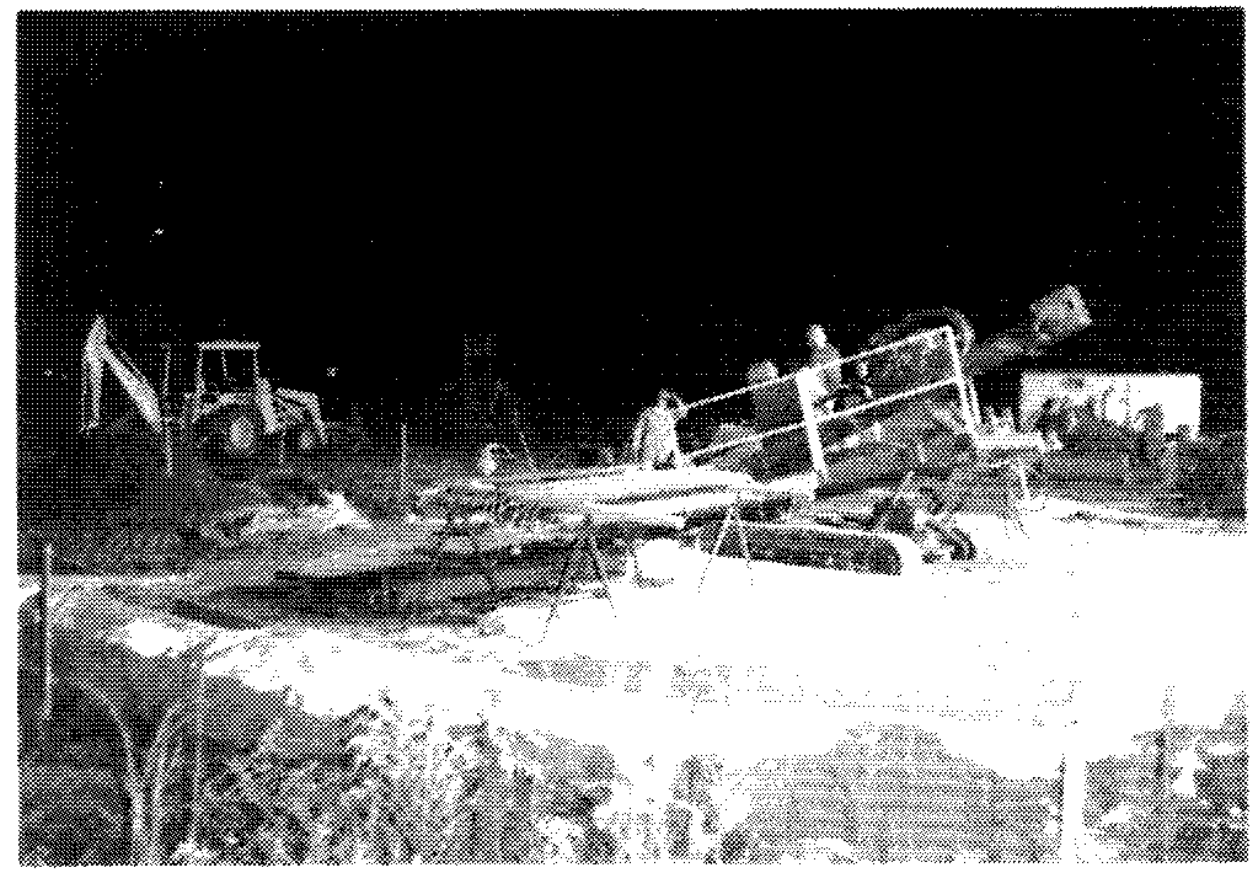

Obique View of the MC.90 Drilling Rig with two inch drill steel in foreground. This view displays the difficulties encountered with operating under spotights.

Figure C.1. Night Shift Drill Setup 
Demonstration of River Crossing Technology for Installation of Envinonmental Korizontal Wells: AMH-6 and AMH 7 Installation Report CDM Federal Programs Corporation

May 5,1993
Westinghouse Savannah River Company Subcontrack No. AA46325P Task Order No. 10

THIS PAGE INTENTIONALLY LEFT BLANK 
Demonstation of eiver Crossing rechnology for Installation of

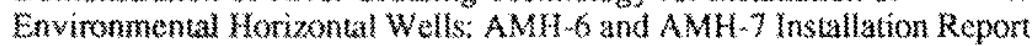
COM Faderal Promams Comoration Aay 5,1093
Westinghouse Savannah River Company Subcortract No. AA46325\% Task Order No. 10

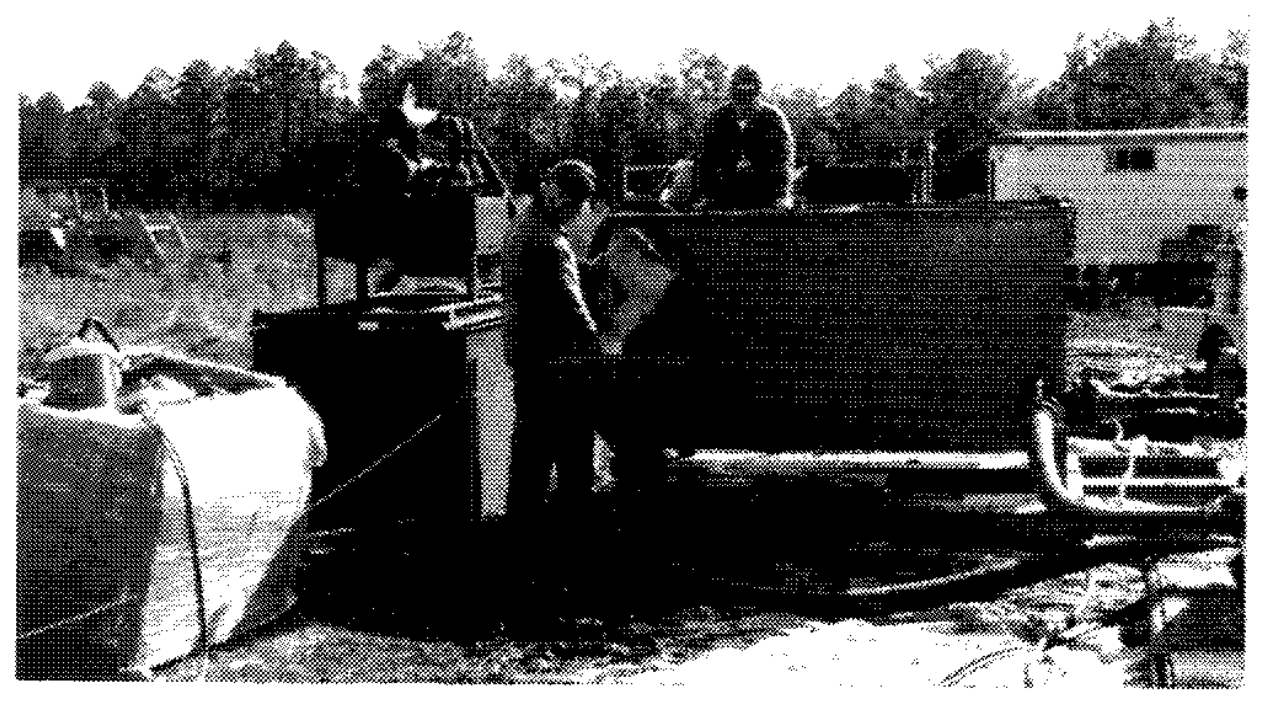

View of mud mixing system with helper adding a bag of guar gum into the hopper to be mixed into the drilling mud.

Figure C-2. Close-Up of Mud System 
Demonstration of River Crossing Technology for Installation of Environmental Horizontal Wells: AMH-6 and AMH -7 Installation Report CDM Federal Programs Corporation

May S, 1993
Westinghouse Savannah River Company Subcontract No. AA46325P Task Order No. 10

THIS PAGE INTENTIONALLY LEFT BLANK 
Demonstration of exper Crossing Technology for Installation of

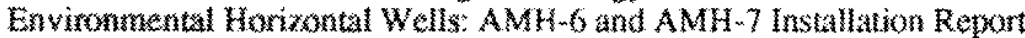

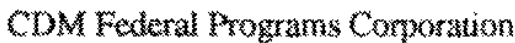

May $\$, 1993$
Westinghouse Savanah River Company Subontract No. AA46325P Task Order No. 10

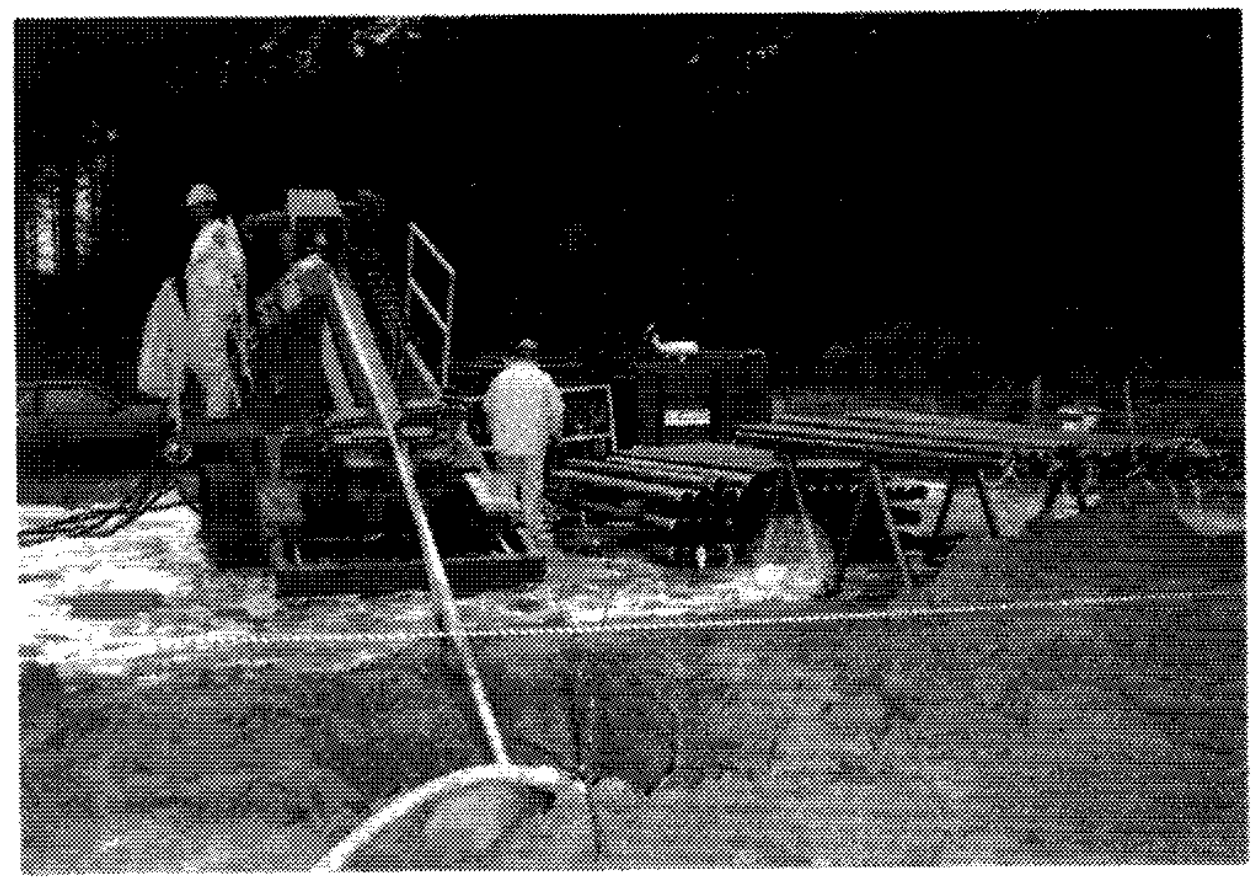

Layout of foum mon and wownch drill steel on racks. Each layer is numbered sequentially for tacking rod couns. Note the fwo-inch drill pipe has sections of white survey wire inserted. allowing for easier and faster survey tool comnection.

Figure C-3, Drill Steel Racks 
Demonstration of River Crossing Technology for Installation of Environmental Horizontal Wells: AMH-6 and AMH-7 Installation Report

Westinghouse Savannah River Company CDM Federal Programs Corporation

Subcontract No. AA46325P

May 5,1993

\section{THIS PAGE INTENTIONALLY LEFT BLANK}


Demonstration of River Crossing Technology for Installation of

Westinghouse Sayatmalk River Company Exnimonemental Hotizontal Wells: AMH-6 and AMH-7 Installation Report CDM feckral Programs Corporation Subcontract No. AA46325P May $\$, 1993$

Task Order $\mathrm{No} .10$

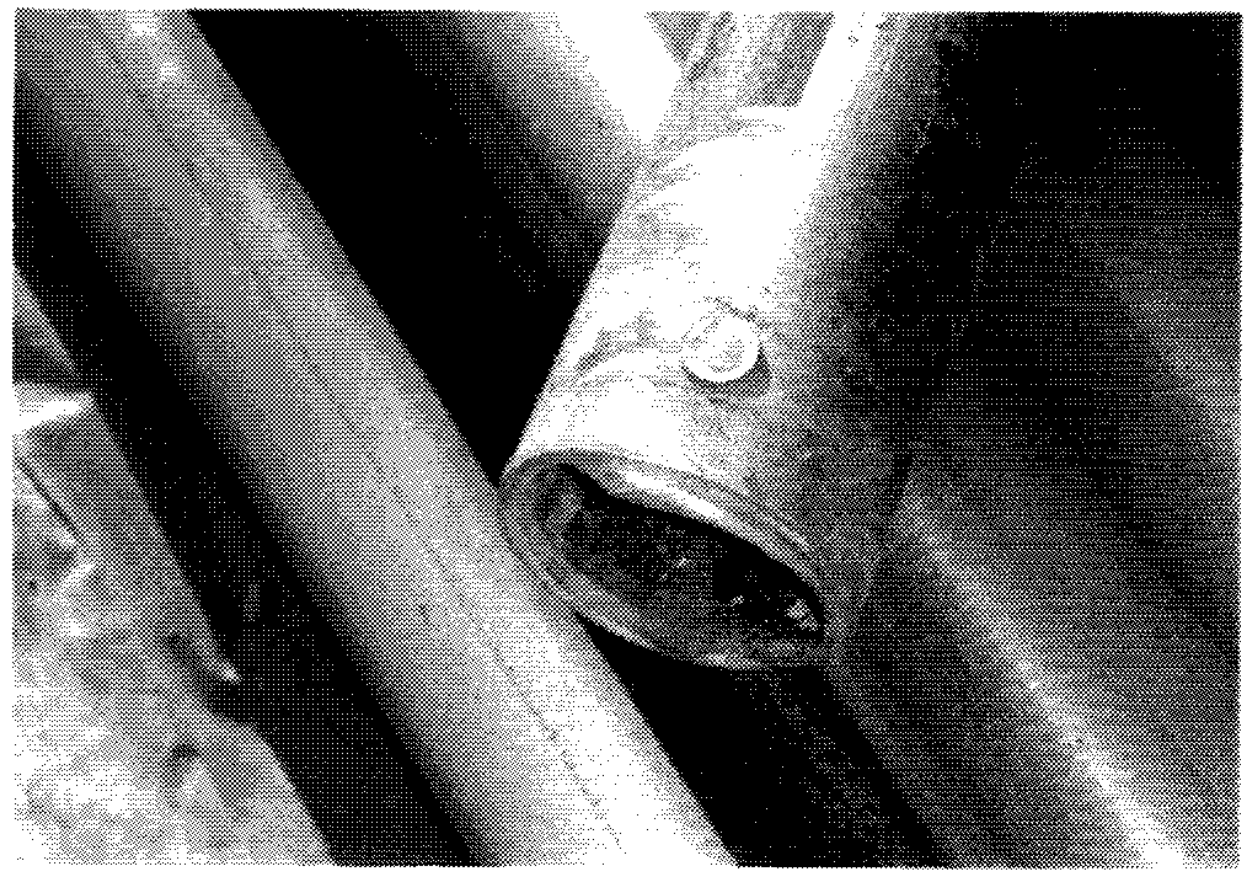

Close-up of the broken end of a section of four-inch washover pipe with quarter for scale. Note how the end is rounded where the driller attempted to advance the pipe after separation.

The box of this pipe was left attached to the pin of the pipe below it.

Tugure C-4. Broken End of Four-Inch Washover Pipe 
Demonstration of River Crossing Technology for Installation of Environmental Horizontal Wells: AMH-6 and AMH- 7 Installation Repor CDM Federal Programs Comporation

May 5,1993
Westinghouse Savannah River Company Subcontract No. AA46325P Task Order No. 10

\section{THIS PAGE INTENTIONALLY LEFT BLANK}


Demomstration of River Crossing Technology for Installation of

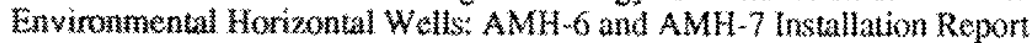
CDM Feden Promatum Comporation May 5,1993
Wastinghouse Savanuh River Company Subcontrat No. AA46325P Tusk Order No. 10

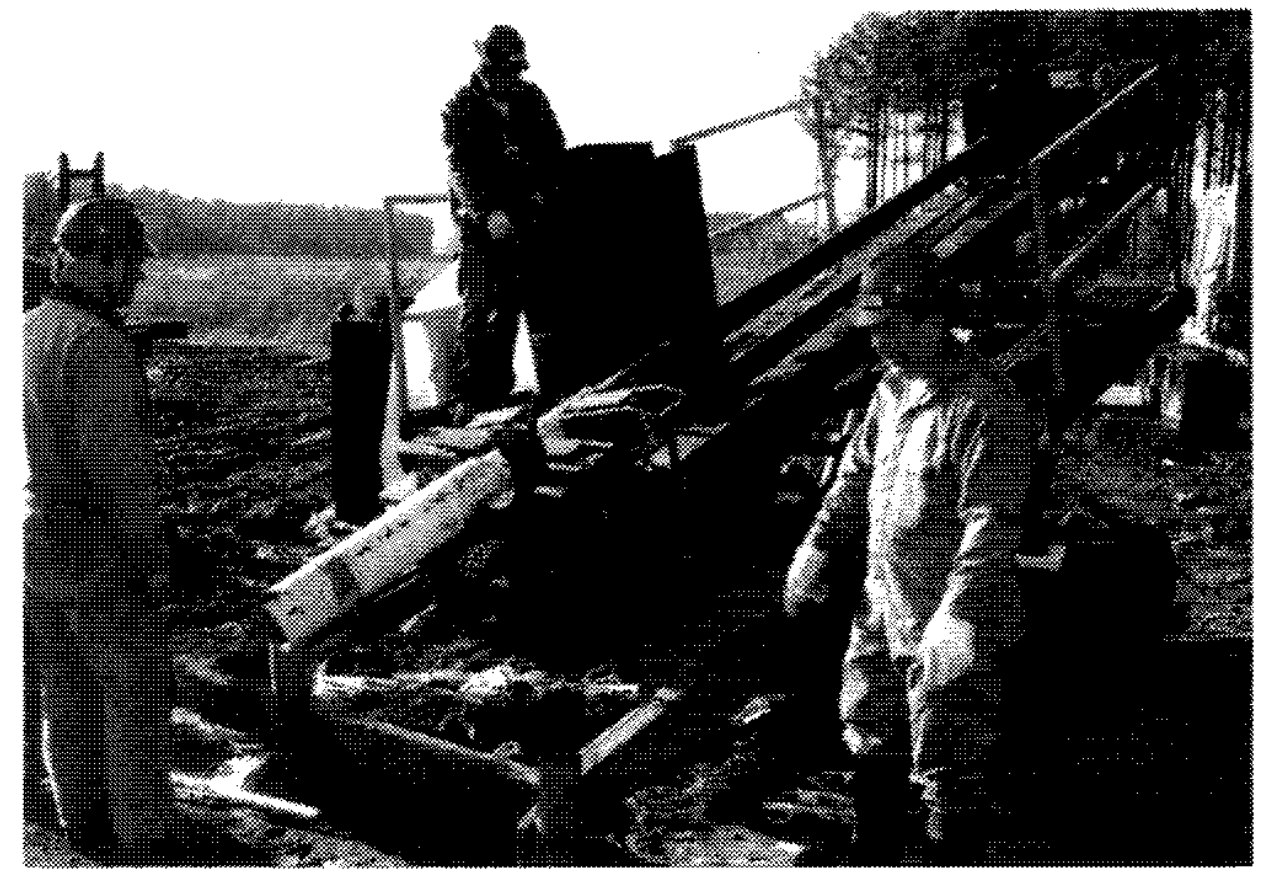

View of fishing tool atached to the end of the four-inch washover pipe.

Wigure $C .5$. Fishing Tool Preparing to be Installed 
Demonstration of River Crossing Technology for Installation of Envitonmental Horizontal Wells. AMH-6 and AMH-7 Installation Report CDM Federal Programs Corporation

May 5,1993
Westinghouse Savannah River Company

Subcontract No. AA46325P

Task Order No. 10

\section{THIS PAGE INTENTIONALLY LEFT BLANK}




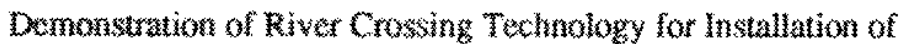
Einyiratanental Horizontal Wols: AMH 6 and AMH 7 Installation Report CDM Foderal Fromams Comotation

Mas 5,1993
Wescinghouse Savannah River Company Subcontract No. AA46325P Task Order No. 10

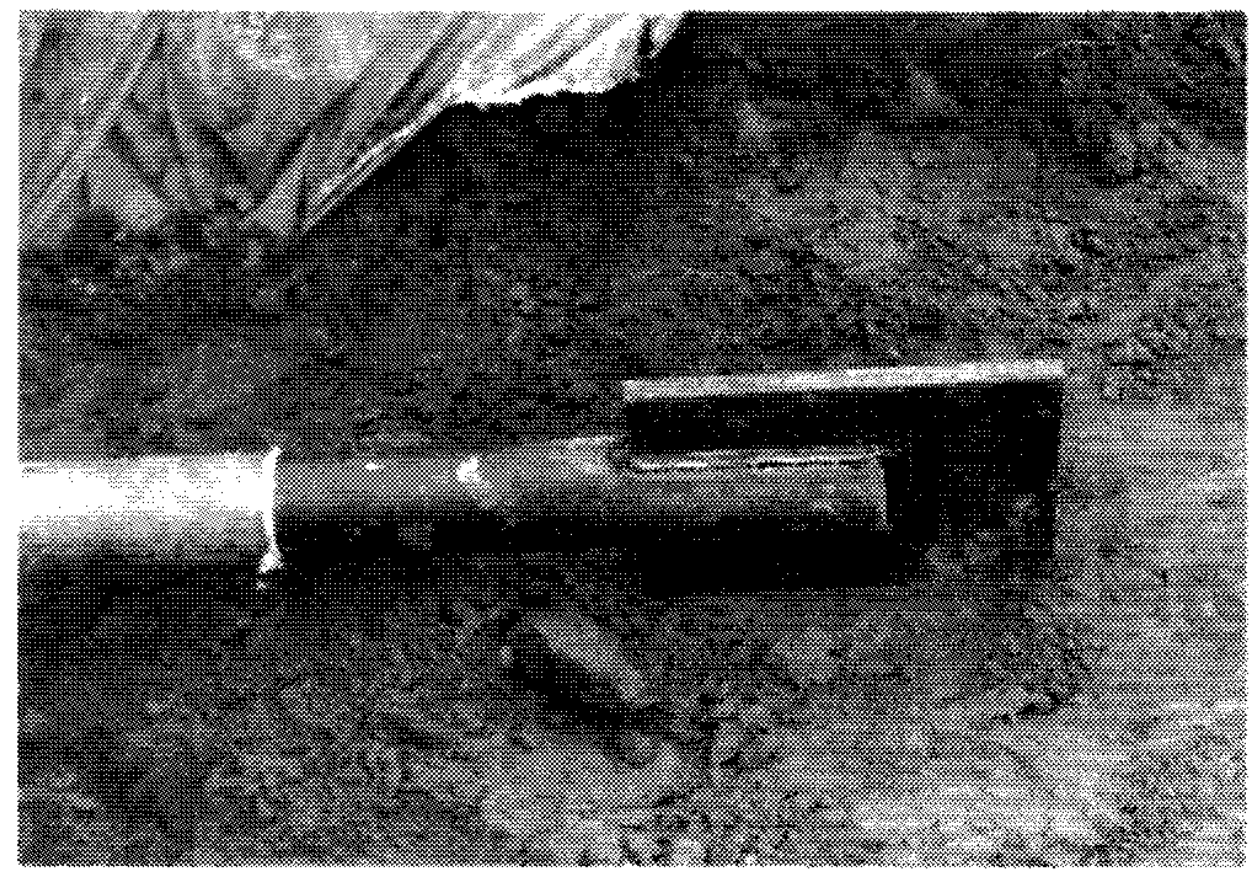

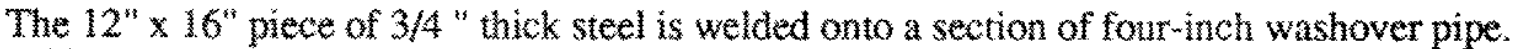
This device is then screwed into the four-inch washover string and the vibrating hammer is clamped onto the flat surface.

Figure C-6. Plate for Attaching Hammer to Four-Inch Washover Pipe 
Demonstration of River Crossing Technology for Installation of Environmental Horizontal Wells: AMH -6 and AMH-7 Installation Report CDM Federal Programs Corporation

May 5,1993
Westinghouse Savannah River Company Subcontract No. AA46325P Task Order No. 10

THIS PAGE INTENTIONALLY LEFT BLANK 


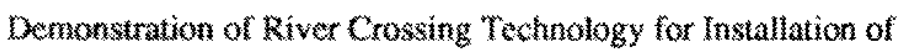

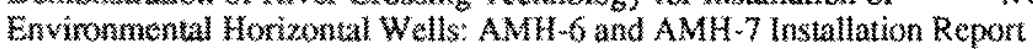
COM Fodera Proyramo Comoration

May 5,1993
Westinghouse Savannat River Company Subcontract No. AA46325\% Task Order No. 10

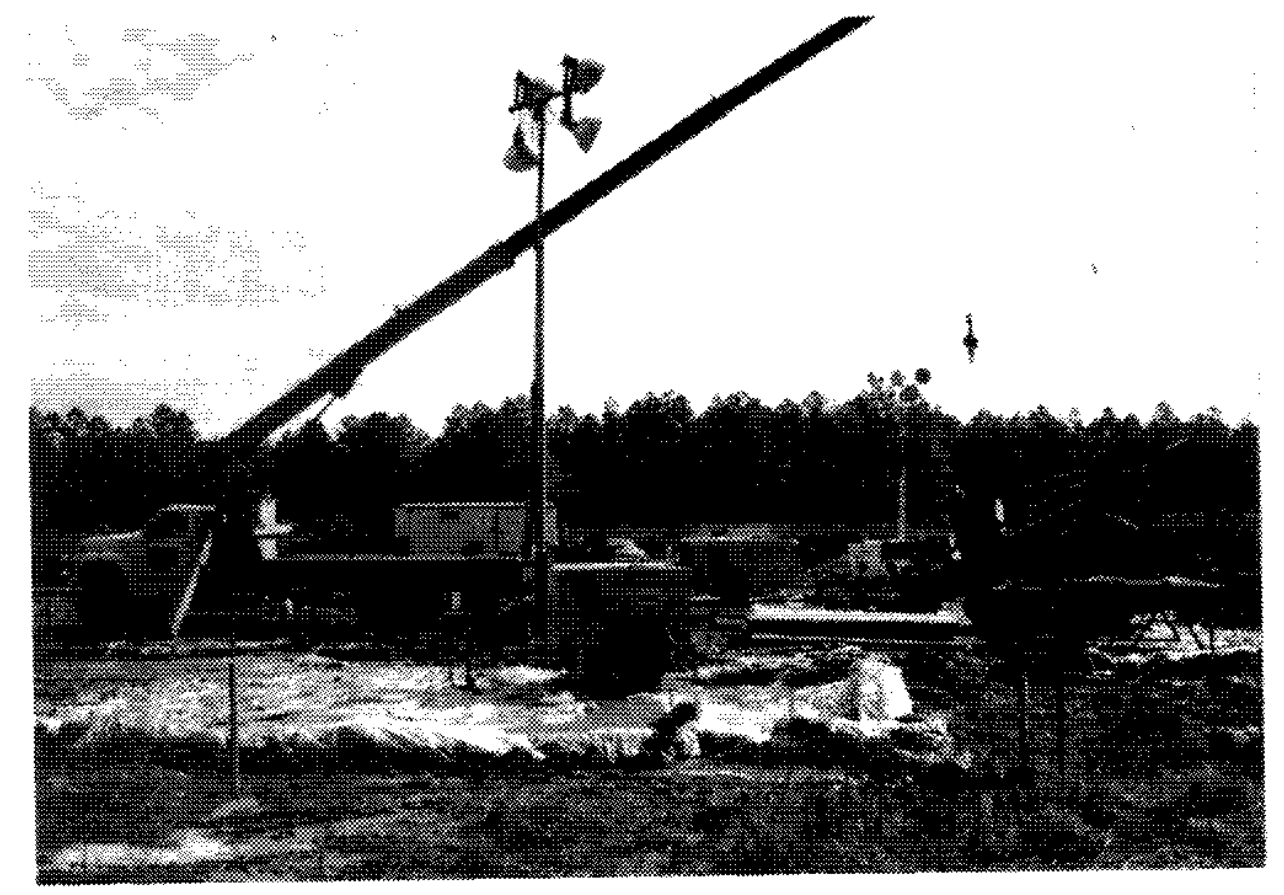

A crane had to be brough in to lift the hammer off of the flat bed truck and place it in the drill pit for installation.

Figure C.7. Crane for Moving Vibrating Hammer 
Demonstration of River Crossing Technology for Installation of Exwironmental Horizontal Wells: AMH-6 and AMH-7 Installation Report CDM Foderal Programs Corporation

May 5,1993
Westinghouse Savannah River Company Subcontract No. AA46325P Task Order No. 10

\section{THIS PAGE INTENTIONALLY LEFT BLANK}


Demonstration of Liver Crossing Techmology for Installation of Envioumental Horizontal Wells: AMH-6 and AMH 7 Installation Report CDM Federal Prowans Comoration

May $\$, 1993$
Westinghouse Savannah River Company Subcontract No. AA46325P Task Order No. 10

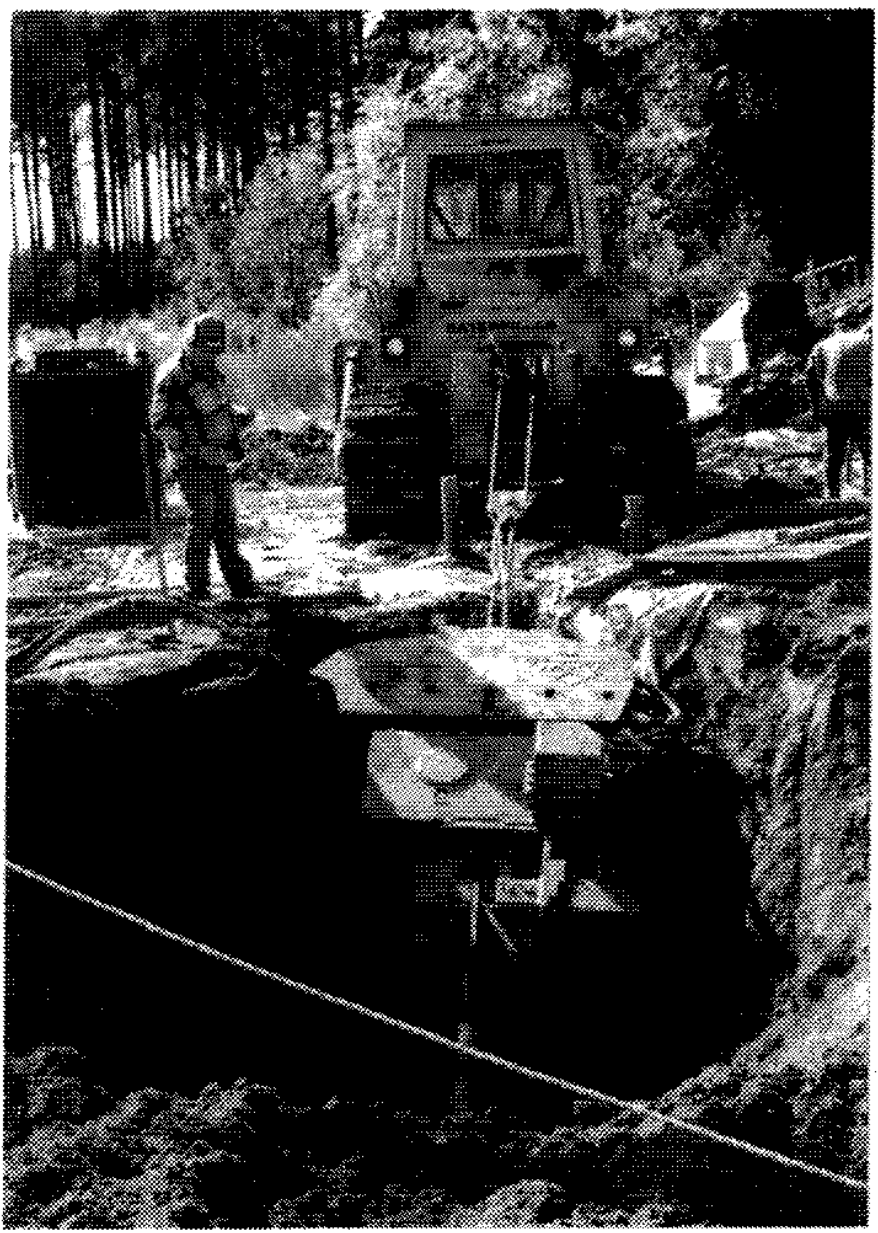

View of the drill pit with the four-inch washover pipe in the foreground attached to the vibrating kammer. The D 8 Bulldozer is pullng on the assenbly with lutue sucess.

There C-8. D.8 Bullower Pulling on Stuck Washover Pipe 
May 5,1993

\section{THIS PAGE INTENTIONALLY LEFT BLANK}




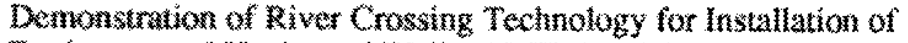
Enwironzmental Horizontat Wells: AMH-G and AMH-7 Installation Report CDM Fodual rograms Comporaton

May 5,1993
Westinghouse Savannah River Company Subcontract No. AA $46325 \mathrm{P}$ Tatk Orter No, 10

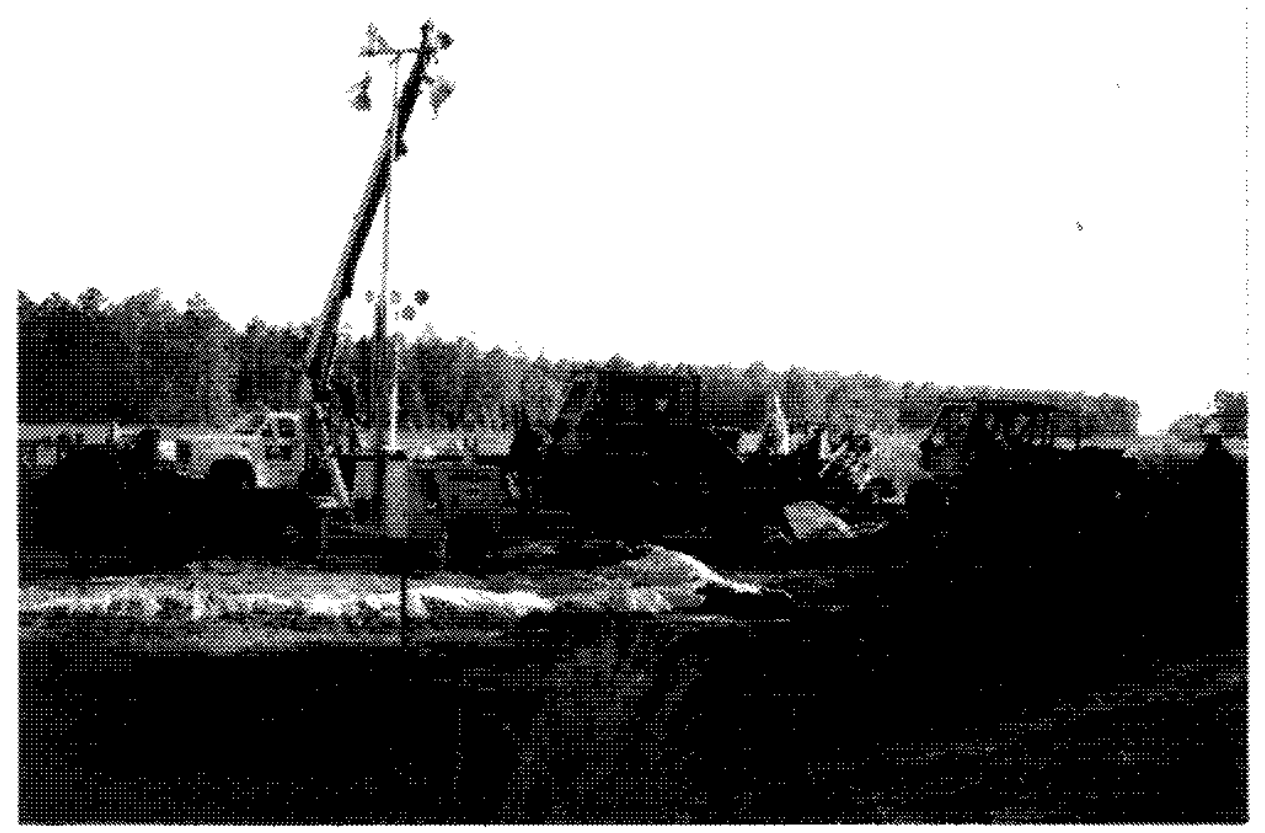

The crew had litule success pulling on the stuck washover pipe with one bullozer so a second was brought in. Both machines pulled on the pipe in tandem and succeeded in moving several sections of pipe before the string broke again downhole.

migure C.9. Two D.8 Bulldozers Pulling in Tandem on Stuck Washover Pipe 
Demonstration of River Crossing Technology for Installation of Westinghouse Savannat River Company Envirommental Horizontal Welts: AMH -6 and AMH-7 Installation Report CDA foderal Programs Corporation Subcontract No. AA46325P May $\$_{3} 1993$

Task Order No. 10

\section{THIS PAGE INTENTIONALLY LEFT BLANK}


Demonturtion of River Crowsing Technotogy for Installation of

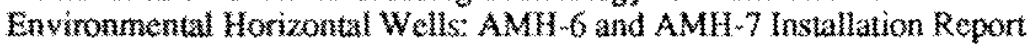
CDN Federal prourams Comporation

May 5,1993
Westinghouse Savannah River Company Subcontract No. AA46325\% Tack Orter No. 10

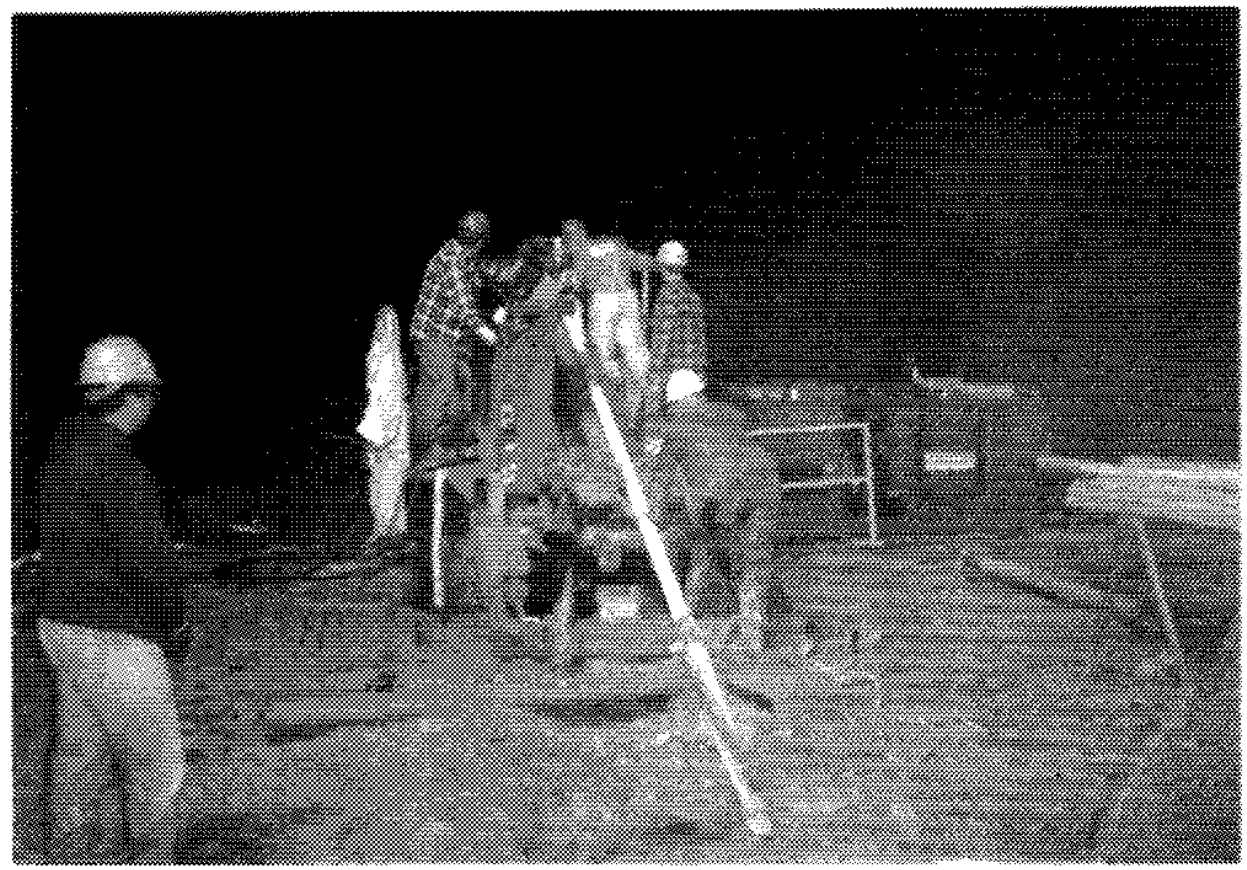

The three-inch PVC sereen and casing was installed by hand until the string could no longer be advanced through manpower alone. The drill head on the rig was then used both to pump drilling mud bown the screen to reduce hydrostatic resistance and to apply slight pressure on the PVC pipe to advance it down the hole.

Figure C-10. Crew Installing Three-Inch PVC Well Screen in Hole 
Demonstration of River Crossing Technology for Installation of Environmental Horizontal Wells: AMH-6 and AMH-7 Installation Report CDM Federal Programs Corporation

May 5,1993
Westinghouse Savannah River Company Subcontract No. AA46325P Task Order No. 10

\section{THIS PAGE INTENTIONALLY LEFT BLANK}




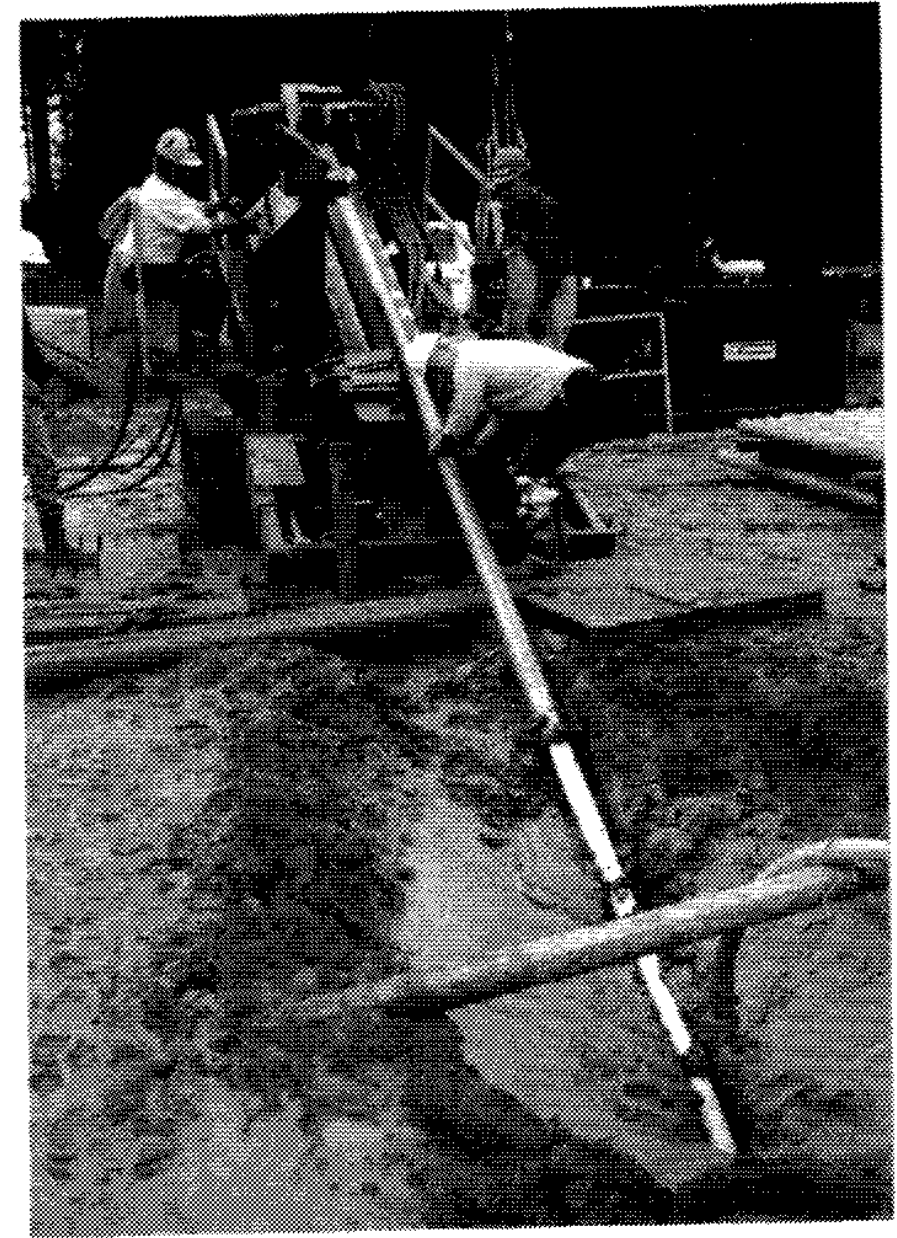

Once the trree-inch PVC sereen and casing were installed to the end of the borehole, the washover pipe was carefully extracted. On AMH -6, the washover pipe became stuck and the decision was made to letve the pipe in the hole instead of chancing damage to the installed well.

Fure C-11. Four-Inch Washover Plpe Being Extracted from Over Installed Well 
Demonstration of River Crossing Technology for Installation of

Westinghouse Savannah River Company Environmental Horizontal Wells: AMH -6 and AMH-7 Installation Report CDM Federal Programs Corporation Subcontract No. AA46325P

May 5, 1993

Task Order No. 10

\section{THIS PAGE INTENTIONALLY LEFT BLANK}


Demonstratson of River Crossing echnology for Installation of

Westinghouse Savannah River Company Eavironmental Horizontal Wels: AMH-6 and AMH-7 Installation Report CDM Fereral Programs Corporation Subcontract No. AA46325P May 5,1993

Task Order No. 10

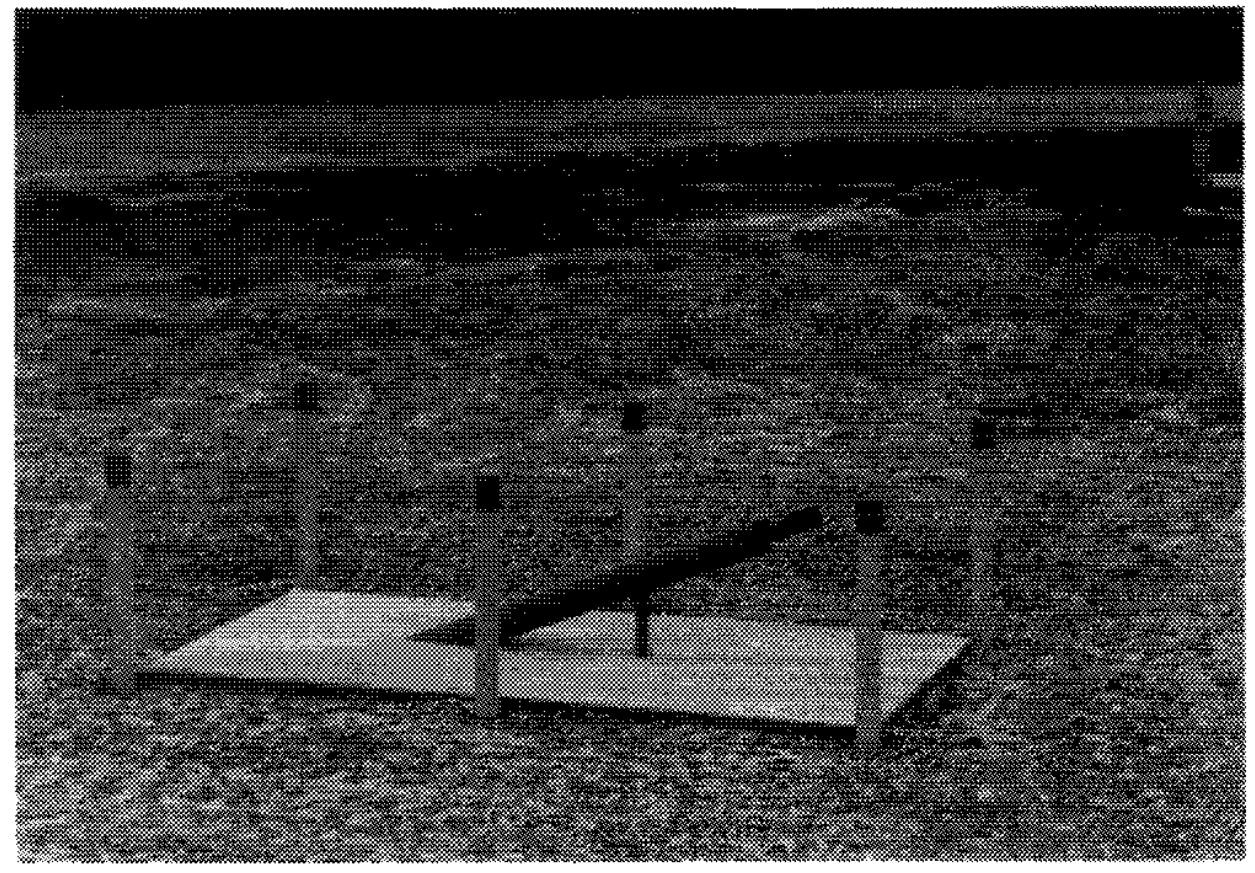

Once all drill steel was removed from the well, the annulus around the casing was grouted to the surface. A 10 foot section of four inch washover pipe was advanced down the hole, over the PVC Casing for stability and a $3^{\text {" }}$ thick concrete pad was constructed around the well. A

locking cap was then welded to the washover pipe. Six sections of washover pipe were advanced into the ground around the pad and filled with concrete. All steel was subsequenty painted for visibility.

Figure C.12. Example of Completed Horizontal Well Pad 
Demonstration of River Crossing Technology for Installation of

Westinghouse Savannah River Company Environmental Horizontal Wells: AMH-6 and AMH-7 Installation Report

Subcontract No. AA46325P

CDM Federal Programs Comoration

Task Order No. 10

May 5,1993

THIS PAGE INTENTIONALLY LEFT BLANK 
Demonstration of River Crossing Technology for Installation of Enviroxmental Horizontal Wells: AMH- 6 and AMH-7 Installation Report CDM Federal Programs Corporation

May 5,1993
Westinghouse Savannah River Company Subcontract No. AA46325P

Task Order No. 10

APPENDIX D

HORIZONTAL WELL CONSTRUCTION DIAGRAMS 
Demonstration of River Crossing Technology for Installation of Westinghouse Savannah River Company Enviromental Horizontal Wells: AMH 6 and AMH - 7 Installation Report CDM Federal Programs Corporation Subcontract No. AA46325P May 5,1993

THIS PAGE INTENTIONALLY LEFT BLANK 
แ6.ม

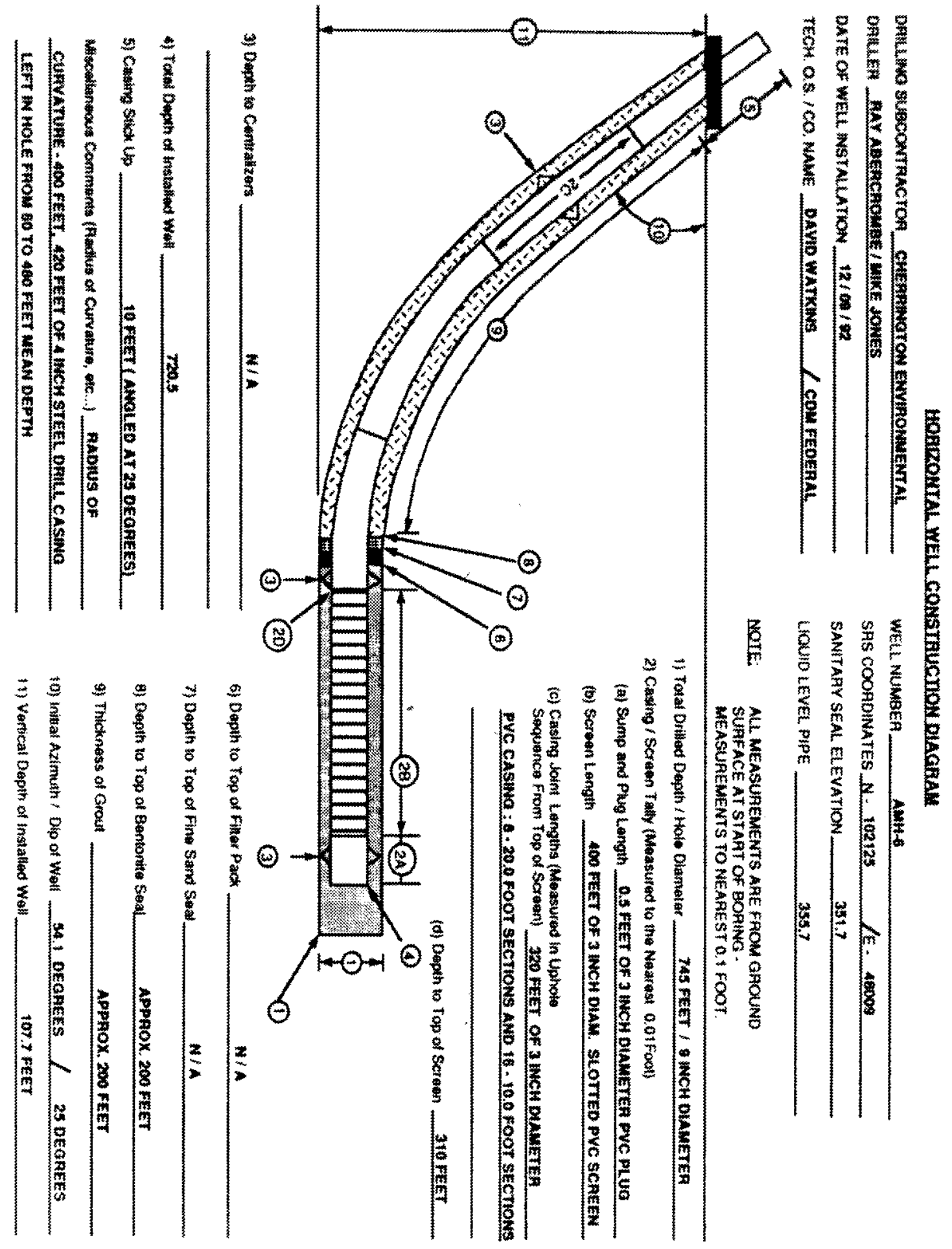

E66I'S KEW

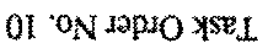

wonerodios sumeroud perpor was

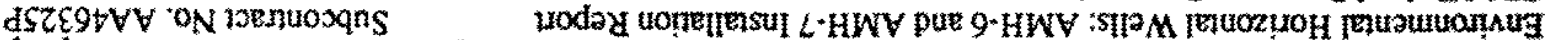

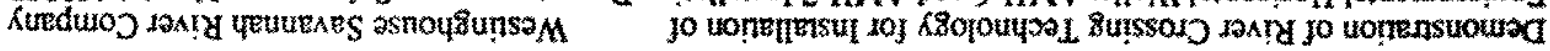




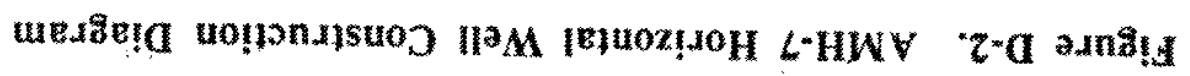

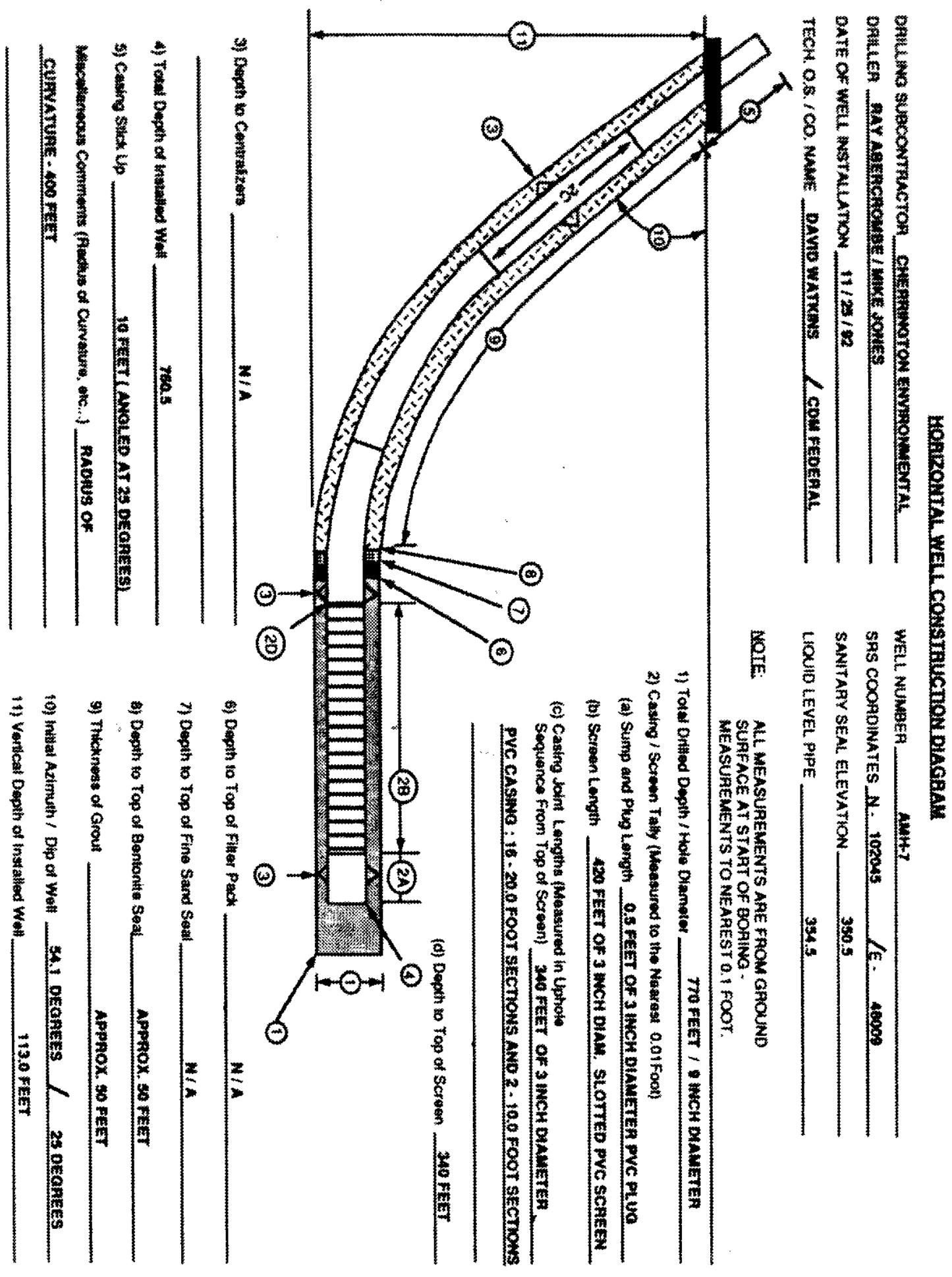

$\varepsilon 661{ }^{*} \mathrm{~S}$ A $\mathrm{KW}$

OI ON DOpHO

uotresodros suret8ox lexpay WaS

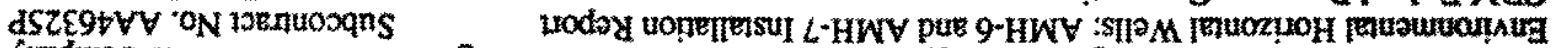

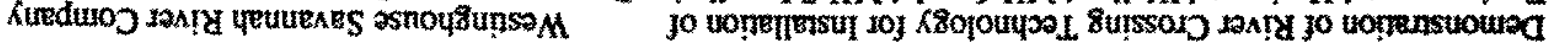


Demonstration of River Crossing Technology for Installation of

Westinghouse Savannah River Company Environmental Horizontal Wells: AMH 6 and AMH-7 Installation Report CDM Federal Programs Corporation Subcontract No. AA46325P

May 5,1993

Task Order No. 10

\section{APPENDIX E}

\section{HORIZONTAL WELL AS-BUILT DIAGRAMS}


Demonstration of River Crossing Technotogy for Installation of Enviromental Horizontal Wells: AMH -6 and AMH-7 Installation Report CDM Federal Programs Corporation

May 5,1993
Westinghouse Savannah River Company Subcontract No. AA46325P Task Order No. 10

\section{THIS PAGE INTENTIONALLY LEFT BLANK}




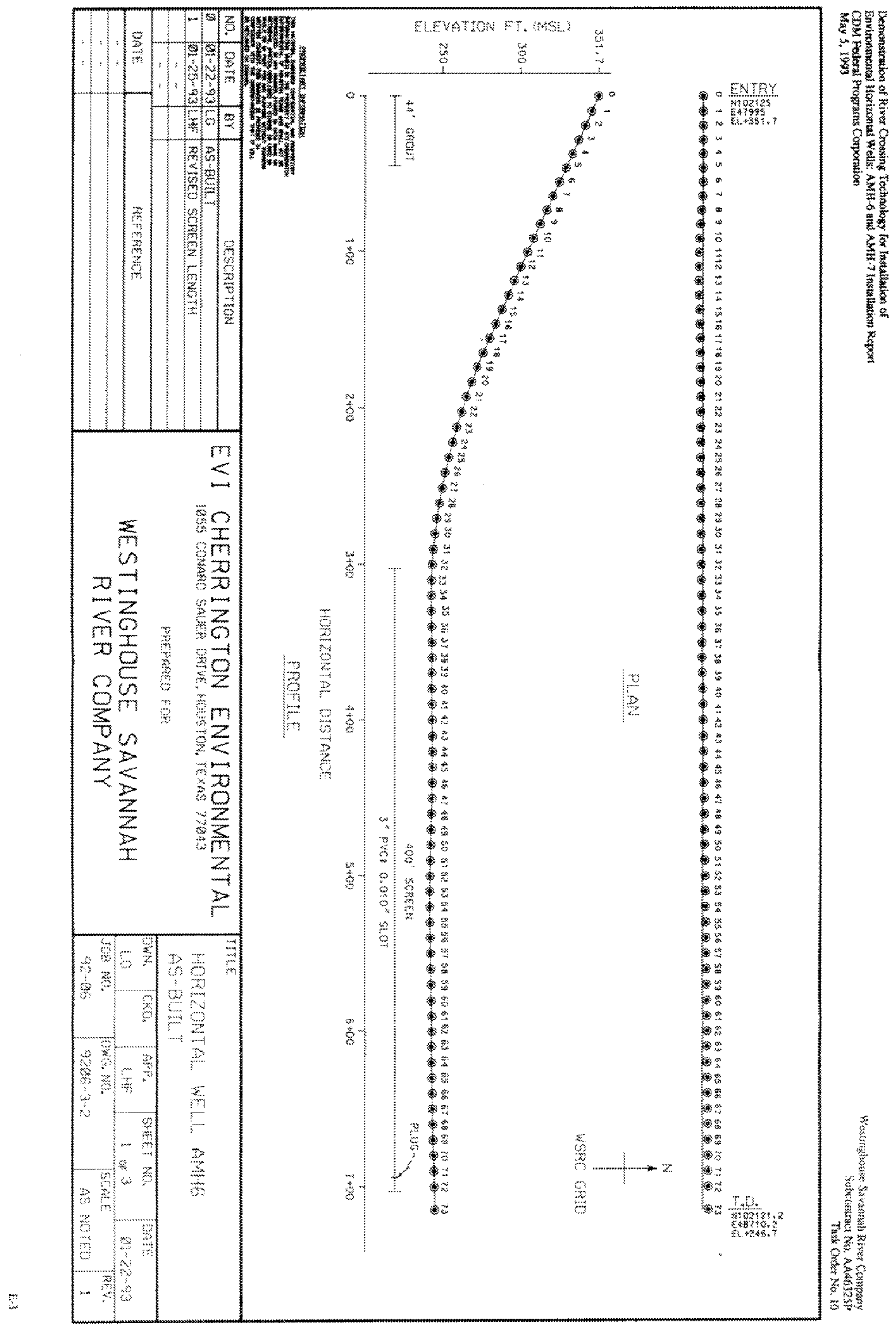




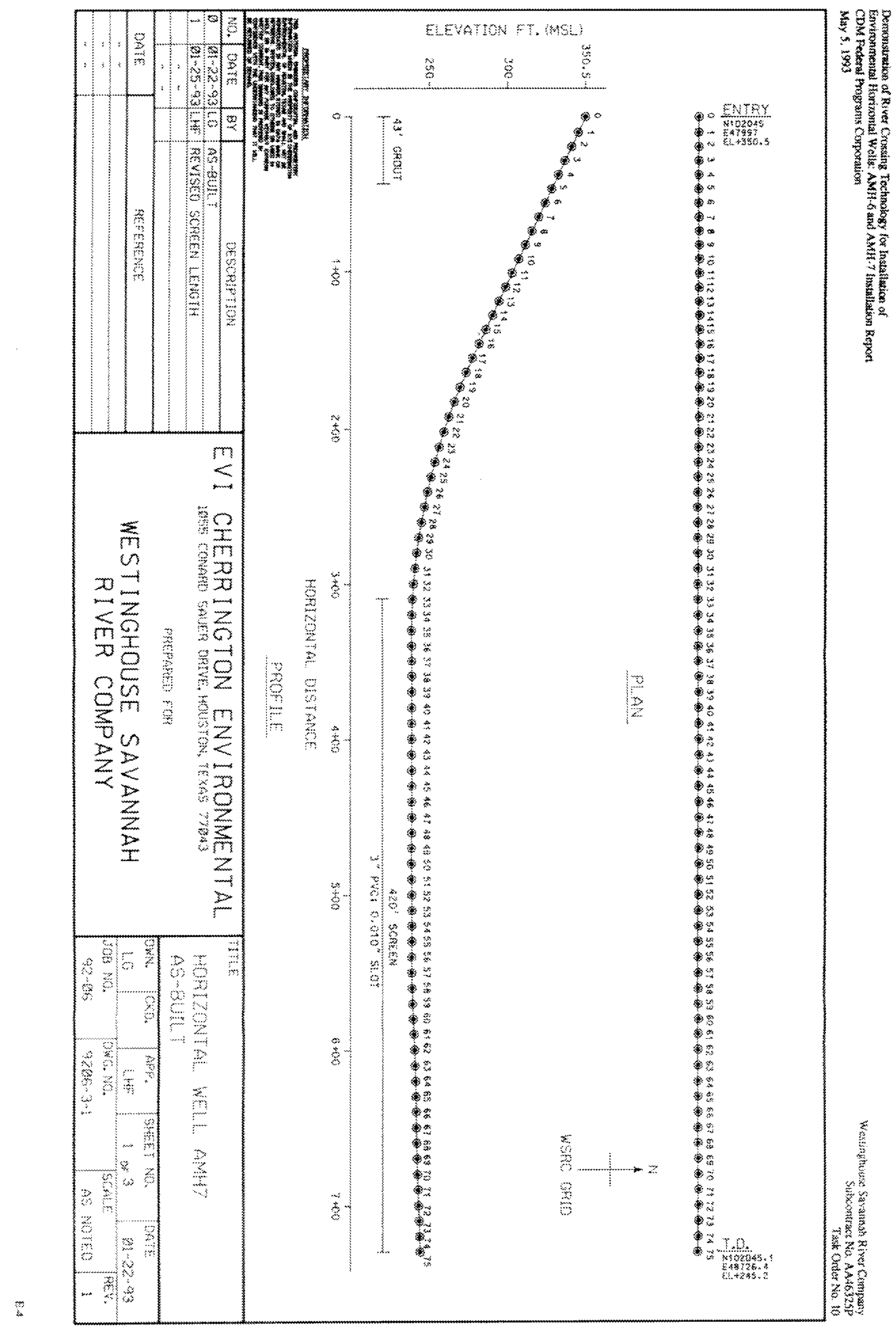


Demonstration of River Crossing Technology for Installation of Environmental Horizontal Wells: AMH 6 and AMH-7 Installation Report Westinghouse Savannah River Company CDM Federal Programs Corporation Subcontract No. AA46325P May 5.1993

Task Order No. 10

APPENDIX F

SPECIFIC INFORMATION ON GUAR GUM DRILLING ADDITIVE (INFORMATION PROVIDED BY EVI CHERRINGTON ENVIRONMENTAL) 


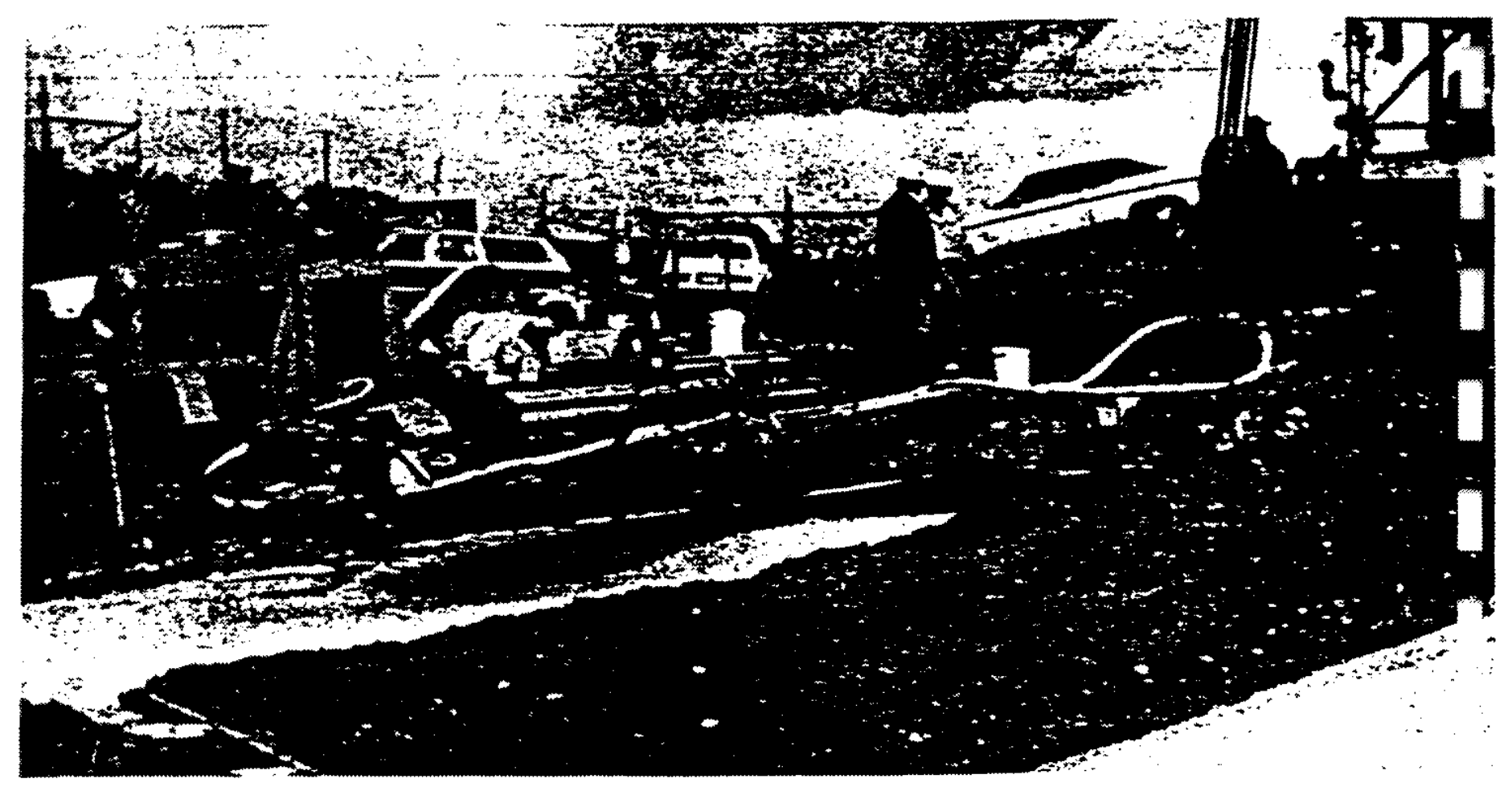

\section{Revert is a natural organic polymer additive which overcomes problems associated with conventional drilling fluids.}

Nevert drilling lluid systems have the following advantuges

* Fotmation dampe is minimized. When drilling flutids are forced into the formation during drilling. the aquiter permeability is reduced if the drilling fluid is not completely removed during well development. With conventional fluid systems. an almost impermeable mud cake can also be formed on the borehole wall. Since Aevert's viscosity can be reduced to nearly that of plain water, its removal during well developments is factitated.

* Caving, swellng and squeaing problems are overcom. Revert encapsulates or coats clays to prevent these problems which occur when chtain clays and shate strata are wetted. Clean. unilomaguge holes are obtained more easily than is possible with bentonite-based mud.

Beller samples ar produced. Because clay does

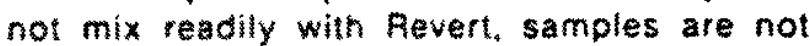
contaminated by extraneous clay materials.
Native clays penetrated by the bit appear as separate and distinct lumps or particlesman essential consideration in test drilling or sampling.

- Cuttings sellle out in the plt much taster. Abrasive sands and other cuttings circulating in the mud system can obscure samples and, more seriously, cause abrasive wear on mud pump sleeves and other parts. Revert's lower gel strength allows these cuttings to seltle faster.

- Penetration rates are increased. The lower density Revert radically reduces fluid friction in the circulating systems. This makes avalable increased energy in the drilling fluid at the drill bit where it is needed. Larger, deeper holes can be drilled faster.

- Power and fuel are more efficiently used. Lower density and reduction in fluid friction also means more efficient use of power. Reductions in hydraulic head loss in pipe flow of $60 \%$ or more are easily attained by using only small amounts 


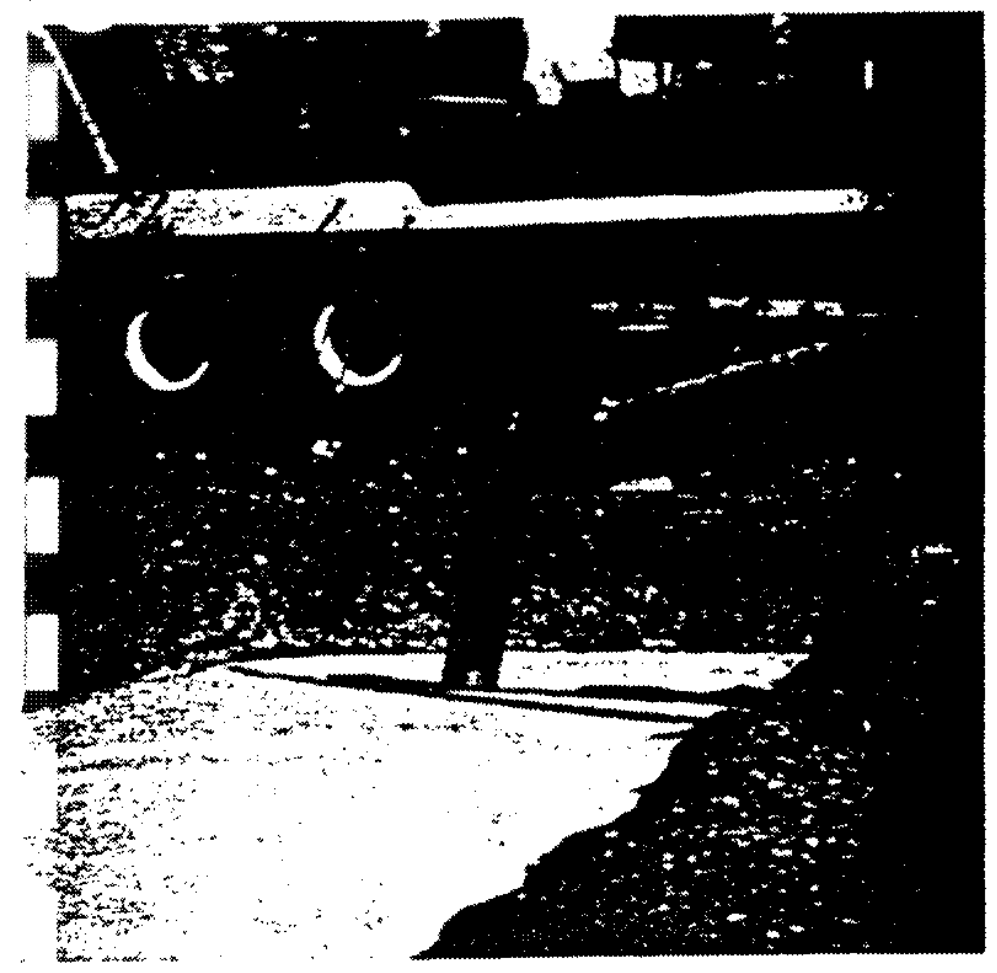

of Revert. Tesis and experience show Revert uses al least $30 \%$ less power than conventional drilling muds

* Less Reverl is needed to do the job. Revert has 8 to 10 imes the viscosity-buiding capacity of bentonite. This meams that a Reverl fluid has only one eighth to one tenth the amount of solids as conventional muds of the same viscosily thus resuling in angher weigh drilling lluid

* Eackish or saline waters pose no problems. Mever, unlike bentonte or native clays, mixes well in these waters. No change in the mud system is meedeo when saline water is encountered during oriling

Electric logging of the borehole is improved. Aquiters containing tresh water tend to have higher resistivity than other water bearing subsurtace lomations. Since driling lluid enters these permeable zones dutng drilling. it is important that the drilling lluid not interfere with this resistivity dilference. Bentonite has a low resistivity which has a masking eflect making reading resistivity differences more difficult. The nigh resistivity of Revert combined with the aquifer's high resistivity causes a marked shilt in the resistivity curve thus aiding in electric 109 interpretation

\section{MIXING REVERT}

Revert is as easy to mix as any conventional drilling fluid. A jet-type mixer is typically used for on-site preparation of the fluid. Other tools common to conventional mud mixing such as a Marsh funnel and cup and mud balance to measure viscosity and weight of the mixed fluid will also be needed. The system's pH can be checked periodically with oH test paper or meter.

As with bentonitic materials, the Revert cannot be dumped unmixed into the mud pit or fed too last into the mixer or it will tend to "gumball" in lumps because of incomplete hydration.

A typical feeding rate of $250 \mathrm{lb} / \mathrm{hr}$ with a standard jet-lype mixer shoulo produce complete wetting of all Revert particles. For small jobs, dry Revert can be sprinkled into a barrel of water in which a paddle mixer or small pump provides needed turbulence. A barrel of fluid thus mixed can be sufficient for a cable tool, auger or jetting operation. Hyoration rates vary with local conditions but generally a suitable viscosity is reached about $1 / 2$ to $3 / 4$ hour after mixing.

\section{FACTORS AFFECTING VISCOSITY}

The viscosity produced by a given amount of Revert in water can be affected by several conditions such as the temperature. pH and salinity of the mix water. The higher the temperature of the water, the more Revert is needed to achieve a given viscosity. Similarly, the higher the water's pH (more alkaline) the longer the hydration time and the lower the viscosity will be from a given amount of Revert. Mixing with saline water rather than fresh water will also result in a lower viscosity Revert nuid

Most natural ground wate has a pH in the range of 5.5 to 8.0. Within that range Revert mixes readily to form a serviceable fluid when used in the ratios described in Figure 1

After mixing, the drilling fluid's viscosity should be measured with a Marsh funnel. At that point. adjustments can be made either by adding more

\begin{tabular}{|c|c|c|c|c|}
\hline 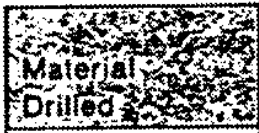 & $\begin{array}{l}\text { Spesiced } \\
\text { onfy } \\
\text { seconds }\end{array}$ & 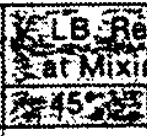 & 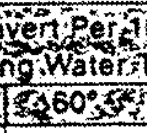 & 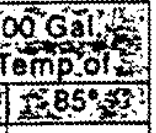 \\
\hline Fine. Sand & 10 & 2.8 & 3.5 & 4.2 \\
\hline Med. Sand & so & 4.2 & 4.7 & 5.6 \\
\hline Coarse Sand & 60 & 4.9 & 5.5 & 6.5 \\
\hline Gravel & 70 & 5.5 & 6.1 & 7.0 \\
\hline Course Gravel & 80 & 6.0 & 6.5 & 7.4 \\
\hline
\end{tabular}

Figure 1. A wattuble viscosity of Revert drilling lluid can be obluined for vartous combinations of lemperatures and formation molerials. 
Acid Neutral Alkaline

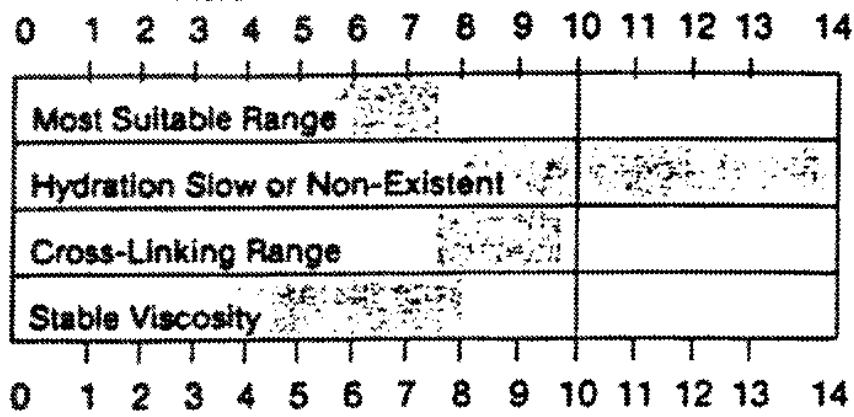

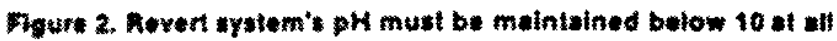
Him:s. For mest application*, neutrat to silghtiy acld pH is best.

Revert or more water. Normally only small amounts of Revert will be needed to account for variations in satinity, pH or water temperature.

\section{SPECIAL FIELD CONDITIONS}

farely. some of the constituents of the water used to mix Revert will have an effect on the mixing rate and the final viscosity of the drilling fluid. This may happen, for example. when treshly placed cement grout is drilled which contaminates the orilling lluid causing the pHi to become extremely high. In this case. the Revert will not hydrate and the drilling fluid will gain no viscosity. In this case. the system must either be wasted or the pH must be reduced. This can be done by adding hydrochioric (muriatic) acid. Johnson's Nu-Well" or some other acio to the system.

II the mix water is high in iron-more than $3 p p m$ (3 mg/l)-it can lorm complex iron compound with the Revert resulting in fluld with less than normal viscosity. Treating the water with about 1.3 $10100 \mathrm{ppm}$. of calcium hypochlorite (HTH) powder per 1,000 gallons of water will disintect the water and oxidize dissolved iron. This effect can also be obtained by using 2 gallons sodium hypochlorite (5\%) per 1.000 gallons of mix water resulting in a 100 pom chlorine solution.

A third condition involves chemical constituents such as heavy metals which can cause Revert - drilling lluids lo gel or can inhibit hydrating of the Rever. Gelled lluids are resistant to flow and might be diflicult to handle. Here, the system must be chlorinated as described above to oxidize the metals if presant. It must also have the pH lowered if necessary by acid treatment as described earlier.

In general, the mix water should be chlorinated it any of the above constituents are suspected to be in the water. if the character of the water is unknown. or it the mix water is from an untreated surface source. Before mixing and during drilling the pH should be maintained near neutral and carry a measurable tree chlorine residual.

\section{VISCOSITY CONTROL}

The length of time Revert will maintain a given viscosity under typical conditions is described in Figure 3.

At high temperatures. Revert tends' to "break down" or lose viscosity more quickly. This is in part due to the growth of certain microorganisms which are most prolific at $60^{\circ}$ to $120^{\circ} \mathrm{F}\left(27-49^{\circ} \mathrm{C}\right)$. Enzymes produced by these organisms in addition to those inherent in the Revert can cause the breakdown of Revert to be accellerated. Where such microorgamisms or soil bacteria are likely to be present, precautions should be taken. If the mud pit is earthen, it should be lined with plastic. The mix water should be disinfected by chlorinating to $100 \mathrm{ppm}$. For other special techniques to use in dealing with premature fluid breakdown, consult Johnson technical service personnel.

On some occasions it may be desirable to accellerate the breakdown of the fluid. One technique involves adding ammonium persulfate (NH.) $\mathrm{S}_{2} \mathrm{O}_{3}$ and terrous sulfate (FeSO) directly to the mud pit in the ratio of one pound of each to each 25 pounds of dry Revert in the fluid system. This fluid is circulated until breakdown occursusually within 10-20 minutes after mixing. If viscosity extenders have been used in the fluid, it may be necessary to increase the ratio of these two chemicals to two pounds or more per each 25 pounds of dry Revert.

If the Revert fluid has penetrated into a very permeable formation it will temporarily reduce the well's efficiency which could result in inaccurate test pumping data. To remove this fluid, the well should be developed by high velocity horizontal jetting with 1,000 ppm chlorine solution which will break down the Revert. This has the added benefit

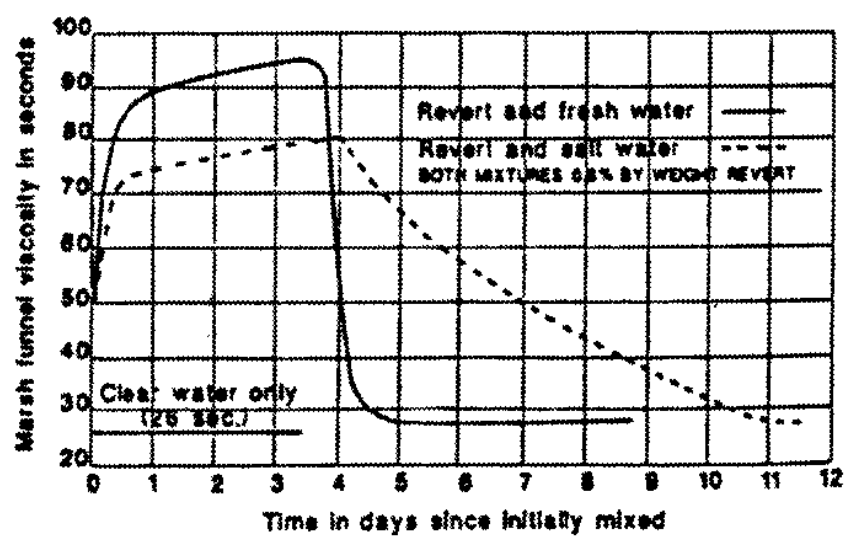

Figure 3. Revert mixes wall with elther tresh or salt water. Curves thow the chenge in thid viscoslty with time in a typlesl drilling thuid of $9.8 \%$ Fenent by welght at $70^{\circ} \mathrm{F}$. 


\begin{tabular}{|c|c|c|c|c|}
\hline \multirow{2}{*}{$\begin{array}{l}\text { Avaliable } \\
\text { Chrorine }\end{array}$} & \multicolumn{4}{|c|}{$P P M$ in $1.000 \mathrm{Gal}$ of Water) } \\
\hline & 50 & 100 & 500 & 1,000 \\
\hline 3* & $3.7 \mathrm{gal}$ & $3.3 \mathrm{gat}$ & $\$ 6.79 *$ & $33.3 \mathrm{gal}$ \\
\hline$\$$ & $1.0 \mathrm{Gal}$ & $20 \mathrm{gal}^{\circ}$ & $10.0 \% 21$ & $20.0 \mathrm{gal}$ \\
\hline 10 & 0.591 & 10 gal. & $50 \mathrm{gal}$ & $100 \approx a !$ \\
\hline 5 & 0.30 al. & $0.7 \mathrm{gal}$. & $3.3 \mathrm{gal}$. & $6.7 \mathrm{gal}$. \\
\hline \multicolumn{5}{|c|}{ 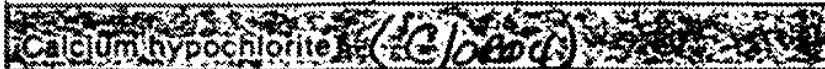 } \\
\hline $65 \%$ & 0.10 & $1.3 \mathrm{lb}$ & 640 & 12.810 \\
\hline
\end{tabular}

Fout 4. The bove quantities ol chorine compounds odded to $\$, 000$ geften of witer wlll produc: the most commoniy used concentrations of chlorine in oriming lluib. Note that sodium

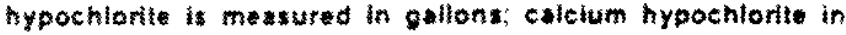
pounds.

of disintecting the well. See figure 4 for mixing chlorine compounds.

When using high chlorine concentrations, it is sometimes beneficial to use sodium hypochlorite (liquid bleach) instead of calcium hypochlorite. This is especially true in fine-grained formations where the tormation water pHis higher than 7 and mignt also contain a significant amount of calcium.

\begin{tabular}{|c|c|c|c|c|}
\hline 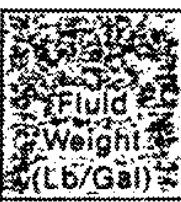 & 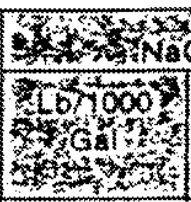 & 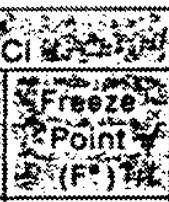 & 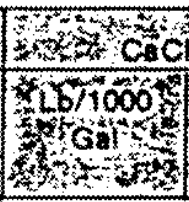 & 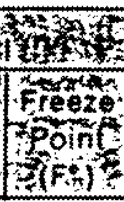 \\
\hline 83 & + & 32 & + & 32 \\
\hline 6.5 & 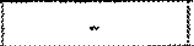 & 29 & - & \\
\hline 6.7 & 531 & 26 & 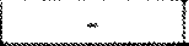 & \\
\hline 8.8 & 725 & 23 & - & \\
\hline 9.0 & 9037 & 10 & $\$ 25$ & 23 \\
\hline 2. & 1356 & 14 & 1136 & 18 \\
\hline$\$$ & 1828 & 8 & 1587 & 13 \\
\hline 86 & 2100 & 2 & 1828 & 7 \\
\hline 8.8 & 2531 & & 2075 & 0 \\
\hline 10.0 & 2926 & & 2363 & -5 \\
\hline 10.2 & m & & 2750 & -15 \\
\hline 10.4 & $*$ & & 3104 & -25 \\
\hline 10.5 & 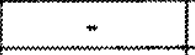 & & 3625 & -35 \\
\hline 10.3 & m & & 3784 & \\
\hline 110 & * & & 1134 & \\
\hline 11.2 & m & & 4486 & \\
\hline 11.4 & + & & $\$ 156$ & \\
\hline 11.65 & - & & 5554 & \\
\hline
\end{tabular}

Figun s. Condition may requirs that Revert drithing liuld be

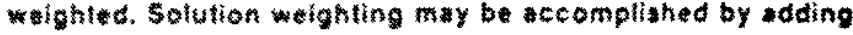

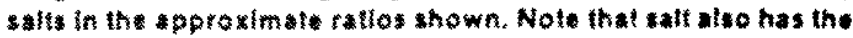
thet of lewering the thud tresting point.
A $1.000 \mathrm{ppm}$ solution of calcium hypochlorite will contain approximately $280 \mathrm{ppm}$ calcium. Calcium has a tendency to precipitate at about $300 \mathrm{ppm}$. Thus, if the combined calcium levels exceed approximately $300 \mathrm{ppm}$, the precipitation of calcium hydroxide could occur in the formation necessitating a follow-up acid treatment to restore the original permeability.

Other conditions may make it difficult to accelerate viscosity breakdown such as the presence of gelled mud or saturated salt mud. These should be handled by the chlorination process described above, but if special problems arise. Johnson technical service personnel are avallable tor assistance.

\section{CONTROLLING FLUID WEIGHT}

The fluid weight of Revert is only slightly higher than that of water-about 8.4 lbs per gal. When dealing with artesian pressures it may be necessary to increase the fluid weight to control water flow into the borehole from the formation and prevent caving. Revert is most effectively weighted by adding salt - calcium chloride or sodium chlorideeither before or after mixing the fluid. This pro. duces a solution-weighted fluid as distinct from suspension-weighted bentonitic fluids. Solution weighting is necessary because a Revert fluid does not have the gel strength required to suspend weighting particles when it is not being circulated. Figure 5 shows recommended approximate ratios of salt to fluid volume to achieve a desired fluid weight.

\section{SPECIAL APPLICATIONS FOR REVERT}

Revert drilling fluids can be applied as "problem solvers" in special circumstances and to entance other conventional drilling procedures.

\section{CONTROLLING FLUID LOSS}

One problem often encountered by drillers is lost circulation in which dritling fluid is lost in a highly permeable zone. Two methods are avallable to solve this problem:

The first method requires an extremely viscous Revert fluid-120 Marsh funnel seconds or more. (The friction reducing properties of Revert allow this to be circulated without special equipment.)

A mass of this freshly mixed highly viscous Revert must now be spotted in the hole opposite the lost circulation zone. Enough of this Revert fluid to twice fill the borehole annulus should be mixed in a separate tank or pit and pumped through the orill pipe to this zone. The drill pipe is then pulled back allowing the viscous Revert to migrate into the permeable zone, thus sealing it oft. Atter about 30 minutes, the viscosity of the remaining fluid can be reduced and normal drilling can resume. 
The second method involves mixing Borax with Revert to create dense, rubbery plugging material. Rig-side expartmentation with a few quarts of fluid 15 useful to determine mix ratios but generally one can proceed as follows: (1) Mix one cup of "20 Mule Team Borax" in 5 gallons of water, then pour the borated water directly into the drill stem. (2) Mix a pit of highly viscous Revert-about 120 Marsh funnel seconds. (3) Raise the pH of this fluid to 9.0 to 9.5 by adding soda ash as needed. Start by dissolving a cuptul of soda ash per 1,000 gallons of wate and slowly add to circulating Revent system at the pump suction. System pH should be checked periodically while circulating and should be kept below 10 to avoid polymer destruction. (4) Mix additional borated water at the ratio of one cup borax per 5 gallons of water. (5) Place bottom of drill stem opposite lost circulation zone. (6) Raise pump suction to near pit surface level. (7) Activate pump id iding speed and when Revert starts to tlow, pour borated water into the pit near the pump suction. Continue pumping until borated Revert appears at ground surface in the annulus between drill stem and bore. It will be thick. gelled mass. (8) Shut pump down immediately to prevent gel from reaching pit. (9) Pull drill stem back one or two length and wail 30 minutes for gel to cure. (10) Resume drilling operation with pump operating at reduced speed until several feet of new formation has been penetrated. (11) Repeat entire operation if necessary. If used in an aquifer where a screen has been ser, it may be necessary to develop the well by high velocity fetting with 1,000 ppm chlorine solution. (Extreme care must be used when handing high concentrations of chlorine.)

The gelled lluid may be returned to its starting viscosity by reducing the pH to 7 or lower.

\section{EXCESSIVE FLUID LOSS}

Reducing the amount of Revert or Borax used or using pH above 7 but less than 9 will weaken the chemical crossulinking bond of the Revert polymer nd produce a partially gelled, stringy mass that can be asily pumped or circulated. This partially cross-linked gel can be used where excessive fluid loss is problem as, for example, when encountering coarse sand and gravel or other highly permeable zones.

\section{REVEAT IN CABLE TOOL DRILLING}

Revert can be used in any situation where clay slurries are used in cable tool drilling. It provides superior lubrication to faclltate driving the casing. II can aiso be used to support the hole when casing has been diven to refusal and it is necessary to drill open hole beyond the casing bottom. The fluid also reduces triction between borehole and tool string which increases cable tool efficiency and speeds penetration rates.

It can be used to pressurize a formation to control heaving sands. (See the section in this bulletin on controlling fluid weight.)

\section{REVERT IN REVERSE CIRCULATION DRILLING}

Revert is also useful in reverse circulation drilling to greally increase drilling efficiency allowing larger, deeper holes to be drilled more quickly. As little as 5 pounds of Revent per 1,000 gallons of water can decrease friction loss in the fluid system by as much as 60 per cent. Revert may be periodically added to chlorinated drilling water at the pump suction during drilling to reduce friction.

A more viscous Revert fluid such as used in conventional rotary drilling can also be used to control fluid losses, lost circulation, swelling and caving shales and clays and other common reverse circulation problems.

\section{REVERT IN AIR FOAM DRILLING}

Small amounts of Revert added to the injected loammproducing agent will make a tough, stable foam with very good water-litting, cutting-carrying and particle suspension properties. Using one pound of Revert (about $26 \mathrm{oz}$. dry measure) per 100 gallons of injection fluid will permit excellent hole cleaning at low annular velocities and air delivery rates. The other beneficial properties of Revert help reduce sloughing and caving, lubricate the bit and protect the permeability of the formations penetrated. As in other Revert applications. the fluid can be broken down when desired with chlorine solution.

\section{COLD WEATHER DRILLING}

Adding salt to Revert drilling fluid has the effect of lowering the fluid treezing point. Figure 5 indicates approximate amounts of sall to achieve a desired result.

\section{REVERT IN PIEZOMETER WELLS}

Hydraulically efficient piezometer and observation wells can be more quickly and easily installed with Revert than with clay additive orilling fluid. Since small piezometer wells are often not developed, the damage to hydraulic conductivity caused by clay-based fluids is unrepaired.

If several test holes are planned close to one another it may be advantageous to mix the Revert in portable tanks which can be skidded from one site to another. Alternatively, the Revert can be pumped from one site to the next.

REVERT IN WELL RECONSTRUCTION

Often, a sand-pumping well can be salvaged by 


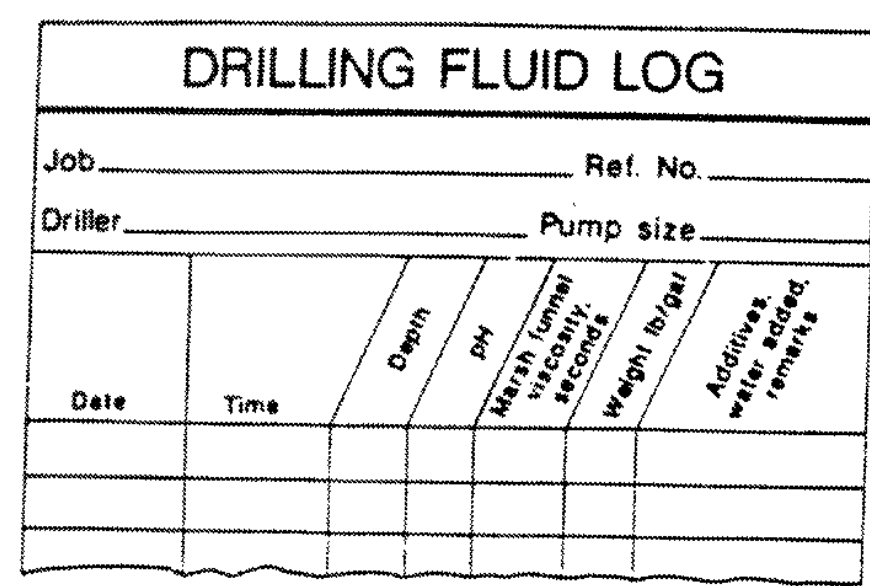

Figure 5. th in important to malntain an wecurate log throughout

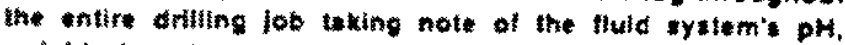

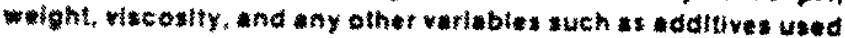
or unubuls conditions encounieted. Such logt serve as secord of work pertormed and ate potemblly usefut relerence tot future lobas.

placing screen liner in a slotted-pipe well. During this process. the existing slotled casing is ripped aimost to destruction before the screen is placed. Chorinated Aevert fluid placed in the hole will provide the support necessary during this and subsequent steps in the well reconstruction. Atter the Revert lluid viscosily is broken, removal of the fluid and development of the well can proceed quickly and thoroughly. This same basic process can be used when pulling and replacing screens in wells.
PLACING gRAVEL PACK WITH REVERT

Revert fluid is ideal tor placing gravel pack by the reverse circulation method. This may be done equally well in new wells or in old wells that were originally completed as open hole and later require a screen and gravel pack combination to stop sand pumping.

\section{REVERT AND BACTERIA}

Revert does not contain or produce any harmful bacteria. Tests on water samples during well development or test pumping may show a high bacteria count. These are not, however, disease-producing bacteria since the organisms in Revert consist of -yeast. mold and lactobaccilli which naturally occur in such loods as flour and milk. These non-pathogenic organisms are also naturally present in food-grade guar. Their presence is not an indication that the well water contains colitorm, Salmonella or other disease-producing germs. In fact, subsequent tests such as the methyl red differential or the eosin methylene blue agar will show that only harmless bacteria are present.

\section{APPLICATIONS ASSISTANCE WITH REVERT}

Johnson technical personnel are avallable to help with Revert applications assistance. Contact your Johnson representative. 